\title{
The impact of selected natural factors on tourism demand
}

Citation for published version (APA):

Oduber, M. F. F. (2020). The impact of selected natural factors on tourism demand: the case of a small island destination. [Doctoral Thesis, Maastricht University]. Maastricht University. https://doi.org/10.26481/dis.20201214mo

Document status and date:

Published: 01/01/2020

DOI:

10.26481/dis.20201214mo

Document Version:

Publisher's PDF, also known as Version of record

\section{Please check the document version of this publication:}

- A submitted manuscript is the version of the article upon submission and before peer-review. There can be important differences between the submitted version and the official published version of record.

People interested in the research are advised to contact the author for the final version of the publication, or visit the DOI to the publisher's website.

- The final author version and the galley proof are versions of the publication after peer review.

- The final published version features the final layout of the paper including the volume, issue and page numbers.

Link to publication

\footnotetext{
General rights rights.

- You may freely distribute the URL identifying the publication in the public portal. please follow below link for the End User Agreement:

www.umlib.nl/taverne-license

Take down policy

If you believe that this document breaches copyright please contact us at:

repository@maastrichtuniversity.nl

providing details and we will investigate your claim.
}

Copyright and moral rights for the publications made accessible in the public portal are retained by the authors and/or other copyright owners and it is a condition of accessing publications that users recognise and abide by the legal requirements associated with these

- Users may download and print one copy of any publication from the public portal for the purpose of private study or research.

- You may not further distribute the material or use it for any profit-making activity or commercial gain

If the publication is distributed under the terms of Article $25 \mathrm{fa}$ of the Dutch Copyright Act, indicated by the "Taverne" license above, 


\title{
The Impact of Selected Natural Factors on Tourism Demand
}

The Case of a Small Island Destination

\author{
Marck F. F. Oduber
}


Photo on cover: Courtesy of Pexels.com Lay-out: Joost Howard and Marck Oduber ISBN: 978-99904-69-68-4 


\title{
The Impact of Selected Natural Factors on Tourism Demand
}

\author{
The Case of a Small Island Destination
}

\section{DISSERTATION}

to obtain the degree of Doctor at Maastricht University, on the authority of the Rector Magnificus, Prof. dr. Rianne M. Letschert, in accordance with the decision of the Board of Deans, to be defended in public on Monday December 14th 2020 at 16:00 hours by

Marck Francis Fritzgerald Oduber 


\section{Promotor}

Prof. dr. P. Martens

\section{Co-promotor}

Dr. J. R. Ridderstaat, University of Central Florida

\section{Assessment Committee}

Prof. dr. ir. J. de Kraker (Chair)

Dr. S.B. Amelung, Wageningen University

Prof. dr. A. Krumeich

Prof. dr. J. H. Stel 
'Look deep into nature, and then you will understand everything better.' Albert Einstein

\section{Preface}

A Ph.D., or Doctorate of Philosophy, is the highest level a student can achieve, which shows that he has made a meaningful new contribution to the chosen field. To reach this level it requires extended study and intense intellectual effort. One needs to have determination, discipline, passion, perseverance, and support. It requires hard work, sacrifice, and the right people to work with.

Ever since finishing my Master of Science, and starting my career at the Meteorological Service of the Netherlands Antilles, I kept interested in science and wanted to learn more and more. Around 2010, the University of Aruba had a program to support and coach qualified academics on Aruba that would like to pursue a Ph.D. in the Netherlands. Around 2012 my determination was set to delve deeper into research and start getting a $\mathrm{Ph}$. D. degree. My determination could mainly be divided into three, namely, ambition, curiosity, and improvement. First, I wanted to achieve something noteworthy; therefore, I had and still have the ambition to challenge myself, push myself to new heights, and achieve challenging goals. Secondly, I had and still have a curiosity to discover or learn new things and love doing research. Thirdly, as a capacity-building experience, I wanted to improve my abilities to understand and solve problems, increase my confidence, and make myself a better scientific communicator.

Once my mind was set, I had selected a theme that I could identify myself with and carry throughout the whole process. While working at the meteorological service of the Netherlands Antilles, it always surprised me how upset and or nervous tourists and people working in the tourism sector on Aruba would get when there was rain on Aruba. Tourists would complain that they came to sunny Aruba, and it was now raining, and hotels would complain, 
for example, about having to move events inside or canceling events. Most of the time, when Aruba gets copious amounts of precipitation due to thunderstorms, it has to do with weather conditions that influence our fresh to strong easterly wind breeze. This influence on the wind pattern will also sometimes make the seas, which are usually calm, near the hotel areas rough. This change from calm seas to rougher than normal seas induces sometimes discomfort for the tourism sector. As a local, and not working in the tourist sector, I get thrilled and excited when finally, Aruba has some active weather overhead. Local farmers also always bless the few times (65 days in a year) that we get more than $1 \mathrm{~mm}$ of rain in a day. The link between the Aruban climate and the tourism sector always intrigued me. Therefore when my copromoter, then head of the research department of the Central Bank of Aruba, approached me to study the link between seasonal movements of climate patterns on Aruba and seasonal movements of stay-over tourists, I was immediately intrigued and joined him. This study, titled, Impacts of seasonal patterns of climate on recurrent fluctuations in tourism demand, Evidence from Aruba, is part of chapter 2, and it forms the inspiration for my Ph.D. research. Tourism is a major global enterprise, which has surpassed the defense, manufacturing, oil, and agriculture industries over the past century. An everincreasing number of destinations worldwide have opened up to and invested in tourism, turning it into an essential driver of socio-economic progress, whereas on no other place on earth has the growth of tourism been as strong as on the islands of the Caribbean, Pacific, and the Mediterranean ${ }^{1,2}$. Tourism has enjoyed virtually uninterrupted growth over time, notwithstanding sporadic shocks, demonstrating its strength and resilience, until COVID-19 happened. According to the UNWTO, the international tourist arrivals fell by $56 \%$, and 320 billion dollars in exports from tourism were lost through May 2020

\footnotetext{
${ }^{1}$ UNWTO Tourism Highlights: 2017 Edition - Hospitality Net. https://www.hospitalitynet.org/performance/4084198.html, retrieved September 15, 2020 ${ }^{2}$ Apostolopoulos, Y., Apostolopoulos, Y., \& Gayle, D. J. (Eds.). (2002). Island tourism and sustainable development: Caribbean, Pacific, and Mediterranean experiences. Greenwood Publishing Group.
} 
worldwide. This loss of international tourism revenue is more than three times greater than the loss during the 2009 global economic crisis ${ }^{3}$. For example, on Aruba, we noticed a 41.3\% drop in cruise ship passengers in 2020 compared to 2019 for the first half of the year ${ }^{4}$. Regarding stay-over tourists, a drop of $60.3 \%$ was observed for the first half of 2020 compared to $2019^{5}$.

The COVID-19 scenario furthers highlights the issue that factors other than price and income account can influence the demand for tourism for a destination. COVID-19 also re-emphasizes UNEP's view on a global increase in zoonotic (diseases, transmissible from animals to humans) epidemics and the link between these diseases and ecosystem health ${ }^{6}$. The inability of the traditional neoclassical economic framework to exploit the known characteristics of tourist goods and services makes it an incomplete approach to tourism demand modeling. It makes the case to further dwell into the study of factors that influence tourism demand. Additionally, I noticed a lack of literature in the duality or combined effect of a destination and origin climate oscillations on tourism flows (Chapter $2 \& 3$ ). Furthermore, geographical mobility, which is a key factor in tourism, could act as a trigger for the spreading of infectious diseases, and the increase of infectious diseases can then act as a deterrent for tourism (Chapter 4). On Aruba, as is the case on other Caribbean destinations, tourism can increase urbanization and destruction of natural habitat (Chapter 5). Increasing urbanization and habitat destruction can lead to concerns about the aesthetic and ecological conditions of a destination. Increasing urbanization and habitat destruction can reduce both the quality of life of the inhabitants of the destination and the economic potential for tourism.

\footnotetext{
${ }^{3}$ World News Tourism Organization Release. https://webunwto.s3.eu-west-1.amazonaws.com/s3fs public/2020-07/200728-barometer-en.pdf, retrieved September 15, 2020

${ }^{4}$ https://www.arubaports.com/main/statistics/, retrieved September 15, 2020

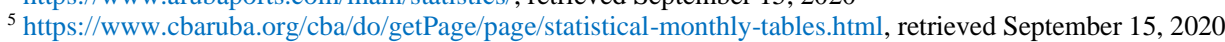

${ }^{6} \mathrm{https}: / / \mathrm{www}$.unenvironment.org/news-and-stories/statement/unep-statement-covid-19, retrieved September 15,2020
} 
Due to several of the factors mentioned in the previous paragraphs, I was intrigued to start investigating the relationship between certain natural factors and tourism demand, in particular for Small Island Destinations as Aruba. More precisely, I started looking into the relationship between tourism demand to climate, infectious disease, and vegetation density. While dwelling further in tourism literature, I was puzzled at first and then realized that no single theory could explain tourism due to the complexness of tourism. This inherent complexness was also why I chose to use three theories in the theoretical framework: Sustainable Development, System Theory, and Chaos Theory. Sustainable Development, mainly due to the idea of a long-term perspective planning, System Theory due to the openness and complexity of tourism demand, and Chaos Theory due to the possible nonlinearity aspect in tourism demand.

I am very grateful for the support I got through Prof. dr. Pim Martens, dr. Jorge Ridderstaat, Prof. dr. Cees Hamelink, dr.Glenn Sankatsing, and my parents, who kept my interest alive and pushed me forward all the time. I am very appreciative of Prof. dr. Pim Martens, who in his busy schedule, has accepted me as an off-campus doctoral student. Prof. dr. Pim Martens and dr. Jorge Ridderstaat were very patient with my lengthy progress and aided me a lot in the reviewing of the published articles and the dissertation itself. Prof. dr. Cees Hamelink and dr. Glenn Sankatsing organized, also, many times on Aruba, 'tertulias' where Ph.D. students or aspiring Ph.D. students could meet and discuss their progress or pitfalls. These 'tertulias' where also a great help and inspiration to continue to work on one's Ph.D. study. I would also like to thank dr. Armando Lampe, who as Minister of Education, Science, and Sustainable Development, gave me the necessary time to finish the last hurdles of my Ph.D., and the University of Aruba who aided me with some of the induced costs for obtaining a Ph.D. 
As I reflect on the last word of this preface, I reflect on how the Ph.D. journey has changed me over the years and how much I enjoyed the capacity development it has brought with it. This journey has filled my spirit with energy to continue researching the fascinating world of tourism.

Marck F.F. Oduber

Oranjestad, Aruba

October 2020 
To

My parents, and my son. 
Contents

1. Introduction

1.1 Purpose and scope of the study 1

$\begin{array}{ll}1.2 \text { Background } & 6\end{array}$

1.2.1 Economic and non-economic factors of tourism demand 6

1.2.2 Climate as a non-economic factor for tourism demand 6

1.2.3 Infectious diseases affecting tourism demand 7

1.2.4 Environmental concerns in developing tourism demand 9

1.3 Theoretical framework 11

$\begin{array}{ll}1.3 .1 \text { General } & 11\end{array}$

1.3.2 Sustainable Development 11

$\begin{array}{ll}\text { 1.3.3 Additional theories } & 14\end{array}$

1.3.3.1 Chaos Theory 14

$\begin{array}{ll}\text { 1.3.3.2 Systems Theory } & 15\end{array}$

1.3.4 Connecting the theories to the study under review 16

$\begin{array}{ll}1.4 \text { Research questions } & 19\end{array}$

$\begin{array}{ll}1.5 \text { Hypotheses } & 20\end{array}$

1.6 Methodological foundations $\quad 22$

1.6.1 A case study approach $\quad 22$

1.6.2 Data decomposition $\quad 24$

1.6.3 Data testing and relationship determinations 25

$\begin{array}{ll}1.7 \text { Research significance } & 26\end{array}$

$\begin{array}{ll}1.8 \text { Outline of the study } & 27\end{array}$

References $\quad 29$

Part I:

Climate Variables $\quad 38$

2. Impacts of seasonal patterns of climate on recurrent 39

fluctuations in tourism demand. Evidence from Aruba

2.1 Introduction $\quad 40$

2.2 Tourism and climate seasonality in the literature $\quad 44$

2.3 Climate conditions and tourism in Aruba $\quad 47$

$\begin{array}{ll}\text { 2.3.1 Climate conditions } & 47\end{array}$

$\begin{array}{ll}\text { 2.3.2 Tourism } & 48\end{array}$

2.4 Data and Methods $\quad 49$

2.5 Empirical results $\quad 58$

$\begin{array}{ll}2.6 \text { Conclusion } & 71\end{array}$

References $\quad 75$ 
3. Impacts of cyclic patterns of climate on fluctuations in tourism demand. Evidence from Aruba

3.1 Introduction

3.2 Materials and Methods

3.2.1 Case study Aruba

3.2.2 Data collection

3.2.3 Wavelet analysis

88

3.3 Results and discussion $\quad 92$

3.4 Conclusion 103

References 106

Part II:

Infectious Disease 112

4. The Bilateral Relationship Between Tourism and Dengue 113 Occurrence: Evidence from Aruba

4.1 Introduction 114

4.2 A Review of the Literature $\quad 116$

4.2.1 Dengue 116

4.2.2 Economic Impact of Dengue 118

4.2.3 Tourism and Dengue Connection $\quad 119$

4.3 Case Study 121

4.3.1 Climate Conditions of Aruba 121

4.3.2 The Tourism Industry of Aruba $\quad 122$

4.4 Data and Methodology 123

4.5 Results and Discussion 134

$\begin{array}{ll}4.6 \text { Conclusion } & 145\end{array}$

References 148

Part III

Gradient in Vegetation 154

5. The Connection of Vegetation with Tourism Development 155

and Economic Growth: A Case Study for Aruba

5.1 Introduction 156

5.2 Material and Methods 158

5.2.1 Normalized Difference Vegetation Index (NDVI) 158

$\begin{array}{ll}\text { 5.2.2 Case Study Aruba } & 160\end{array}$

$\begin{array}{ll}\text { 5.2.3 Methodology } & 161\end{array}$

5.3 Results and Discussion 166

5.4 Conclusion 176

References 178 
6. Conclusion $\quad 183$

6.1 Study Overview 183

6.2 Hypothesis Validations 184

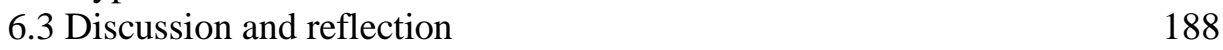

6.3.1 Study Questions 188

6.3.2 Spatial analysis of urbanization and land-use change in a 189 SID

6.3.3 Do oscillations in climate influence tourism demand $\quad 190$

6.3.4 Do oscillations in vector-borne diseases influence tourism 193 demand on a SID

6.4 Theoretical implications $\quad 196$

6.5 Directions for future research 198

$\begin{array}{ll}\text { References } & 200\end{array}$

List of abbreviations $\quad 203$

$\begin{array}{ll}\text { English summary } & 209\end{array}$

$\begin{array}{ll}\text { Nederlandse samenvatting } & 221\end{array}$

$\begin{array}{ll}\text { Curriculum Vitae } & 233\end{array}$

Valorization Addendum $\quad 235$ 
List of tables

Table 2.1: $\quad$ Variables used in the analysis.

Table 2.2: $\quad$ Model type selection based on significance of coefficient 59 of independent variable.

Table 2.3: $\quad$ Explanatory power of time-series elements. 60

Table 2.4: $\quad$ Panel unit root test results. $\quad 64$

Table 2.5: $\quad$ Panel regression results. $\quad 65$

Table 2.6: $\quad$ Months where the EDM is below average. 71

Table 3.1: $\quad$ Raw variables used in the analysis. 89

Table 4.1: $\quad$ Variables used in the analysis. 125

Table 4.2: $\quad$ Best $\lambda$ used for power transformation. $\quad 134$

Table 4.3: $\quad$ Model type on monthly data. 135

Table 4.4: Explanatory power of time-series elements. 135

Table 4.5: Mann-Kendall results. 136

Table 4.6: $\quad$ Panel unit root results. 137

Table 4.7: $\quad$ Panel regression results. 138

Table 4.8: $\quad$ Months where Mahalanobis distance is below average. $\quad 144$

Table 5.1: $\quad$ Unit root results. 167

Table 5.2: Clemente-Montanes-Reyes unit root tests with two 167 structural breaks.

Table 5.3: $\quad$ Zivot-Andrews unit root test. $\quad 168$

Table 5.4: $\quad$ Summaries of unit root tests. 168

Table 5.5: $\quad$ Bounds test for cointergration. 169

Table 5.6: Causality testing NOORD, GDP, and TOUR. 170

Table 5.7: Causality testing ARIKOK, GDP and TOUR. 174

Table 6.1: $\quad$ Summary of the hypotheses and their validations. 187

Table 6.2: Overview of the most important SDGs and targets 195 concerning the prevention of dengue. 
List of figures

Figure 1.1: Theory linkages. $\quad 18$

Figure 1.2: $\quad$ Case of study: Aruba. 23

Figure 1.3: $\quad$ Study outline. $\quad 27$

Figure 2.1: Conceptual framework of the relation between the 49 seasonal patterns of (pull/push) weather and tourism demand for the largest market of Aruba's tourism.

Figure 2.2: Chart 1.1: Standardized seasonal factors of cloud coverage in Aruba.

Chart 1.2: Standardized seasonal factors of rainfall in Aruba.

Chart 1.3: Standardized seasonal factors of temperature in Aruba.

Chart 1.4: Standardized seasonal factors of wind in Aruba.

Chart 1.5: Standardized seasonal factors of rainfall in the USA.

Chart 1.6: Standardized seasonal factors of temperature in the USA.

Chart 1.7: Standardized seasonal factors of wind in the USA.

Chart 1.8: Standardized seasonal factors of tourism demand from the USA.

Chart 1.9: Standardized seasonal factors of rainfall in Venezuela.

Chart 1.10: Standardized seasonal factors of temperature in Venezuela.

Chart 1.11: Standardized seasonal factors of wind in Venezuela.

Chart 1.12: Standardized seasonal factors of tourism demand from Venezuela.

Figure 2.3: Chart 2.1: Euclidean distance of cloud coverage in Aruba and tourism demand from the USA.

Chart 2.2: Euclidean distance of wind speed in Aruba and tourism demand from the USA.

Chart 2.3: Euclidean distance of rainfall in the USA and tourism demand from the USA.

Chart 2.4: Euclidean distance of temperature in the USA and tourism demand from the USA.

Chart 2.5: Euclidean distance of wind speed in the USA and tourism demand from the USA. 
Figure 2.3: Chart 2.6: Euclidean distance of rainfall in Aruba

(continue) and tourism demand from Venezuela.

Chart 2.7: Euclidean distance of temperature in Aruba and tourism demand from Venezuela.

Chart 2.8: Euclidean distance of rainfall in Venezuela and tourism demand from Venezuela.

Figure 3.1: Conceptual framework of the relation between the cyclical patterns of (pull/push) climate data and tourism demand of Aruba's tourism.

Figure 3.2: Wavelet Spectra USATOUR, B) Wavelet Spectra VENTOUR, C) Wavelet Spectra HOLTOUR.

Figure 3.3: A) Average Wavelet Coherence Power USATOUR, MEI, B) Average Wavelet Coherence Power HOLTOUR, MEI.

Figure 3.4: A) Average Wavelet Coherence Power USATOUR, NAO, B) Average Wavelet Coherence Power VENTOUR, NAO.

Figure 3.5: A) Phase Angle USATOUR, MEI (ENSO) (19861987), B) Phase Angle HOLTOUR, MEI (ENSO) (2007-2009).

Figure 3.6: A) Phase Angle USATOUR, NAO (1981-1982),

B) Phase Angle USATOUR, NAO (1992-2015).

Figure 4.1: Conceptual framework of the relationship among dengue, tourism demand, and climate.

Figure 5.1: Conceptual framework of the relationship among vegetation, GDP and tourism demand.

Figure 5.2: Map of points of interest. 




\section{Introduction}

\subsection{Purpose and scope of the study}

Increasing globalization and market liberalization have stimulated international service flows. As part of the international activities in the services sector, tourism has flourished. Given its size, it is now an essential component of international trade and ranks third in terms of exports category, after chemicals and fuels, and ahead of automotive products and food. (UNWTO 2017a). Tourism can be seen as part of the present-day lifestyle and is characterized by two key parameters: geographical mobility and cultural enjoyment (Girard, 2017). The relationship between the tourism sector and sustainable development plays a central role in our increasingly urbanized world. The latter requires the identification of new models to increase urban productivity and make development more sustainable (Girard, 2017). The neoclassical theory of consumer choice, the dominant framework for the analysis of tourism demand in the literature, neglects several peculiarities of the phenomenon, regardless of its theoretical basis (Lorde, Li, \& Airey, 2016). It has been found that factors other than price and income account for at least $30 \%$ of the fluctuation in the demand for goods and services (Lorde et al., 2016). Although several studies in the tourism literature have shown that non-price and non-income factors can influence the choice of destination, in many articles, there is still no consideration of their influence on the demand for tourism (Lorde et al., 2016). The inability of the traditional neoclassical economic framework to exploit the well-known characteristics of tourism goods and services makes it an incomplete approach to tourism demand modeling. These limitations create a case for further dwelling into the knowledge of factors that influence tourism demand. 
This study investigates the relationship between several natural factors and tourism demand for a Small Island Destination (SID). Specifically, the study examines how climate, infectious disease, and vegetation ${ }^{7}$ affect tourism. Also, the study investigates if tourism demand can affect infectious disease or vegetation in the context of a SID. Tourism is one of the largest businesses in the world (Goeldner \& Ritchie, 2012; Lundberg, Stavenga, \& Krishnamoorthy, 1995), and also one of the fastest-growing economic segments (Vanhove, 2005; Salish \& Rodrigues, 2011; Schubert \& Brida, 2011; Apostolopoulos, 1996). According to the United Nations' World Tourism Organization (UNWTO), global tourist arrivals have increased from 25 million in 1950 to 1,401 million (or 1.4 billion) in 2018, while international tourism receipts earned by destinations worldwide increased from US\$ 2 billion in 1950 to US\$ 1,451 billion (or US\$ 1.5 trillion) in 2018 (UNWTO, 2017b; 2019). Expectations are that international tourist arrivals worldwide will increase annually by $3.3 \%$ to reach 1.8 billion by 2030 (UNWTO, 2017b).

Nowadays, an ever-increasing number of destinations have considered tourism an essential driver of socio-economic development through job and enterprise creation, export revenues, and infrastructure development (UNWTO, 2017b). The tourism sector is also entwined with other economic sectors, such as agriculture, fisheries, and transport, and as such, can contribute to the growth of these industries (Moore, 2010), and a greater socio-economic influence (i.e., indirect and induced effects). Estimations by the World Travel \& Tourism Council (WTTC) indicate that the travel and tourism sector accounted for about $10 \%$ of the global GDP and close to $10 \%$ of total employment in the world (or 313 million jobs) (WTTC, 2018a). Calculations by the WTTC also show that, for some countries, the total contribution of travel and tourism to the economy and labor is by far substantial, for instance, in Macao (economy: 72.2\%; labor: 50.5\%), St. Kitts and Nevis (economy: 62.4\%; labor: 59.9\%), Seychelles

\footnotetext{
${ }^{7}$ Burrows (1990) defines vegetation as an assemblage of plant species and the ground cover they provide.
} 
(economy: 67.1\%; labor: 66.7\%), and Aruba (economy: 98.3\%; labor: 99.1\%) (WTTC, 2019a; 2019b). This socio-economic prominence of tourism explains, to some extent, the broad scientific interest in this phenomenon.

A central aspect of tourism development is tourism demand, which has been defined by Frechlin $(2001 ; 1996)$ as a measure of the use of goods and services by visitors. It is the foundation upon which all tourism-related decisions rely upon, as it determines the profitability of airlines, tour operators, hotels, cruise ship lines, recreation facilities, shop owners, and the like (Song, Witt, \& Li, 2009). The imperative nature of tourism demand for the decisionmaking process requires a good understanding of the factors that govern its development. Studies on the causes of tourism demand have historically emphasized only a few sets of factors, most of them of economic nature, such as income, prices, exchange rates, and marketing expenses (Croes, 2010; Goh, 2012; Song et al.,2009). The consequence of this approach is that it has downplayed the role of other clusters of factors influencing the choice of tourists for destinations (Kulendran \& Dwyer, 2010).

In recent years, however, several studies have focused on climate factors, such as rainfall, wind, humidity, temperature, and cloud cover, as additional determinants of tourism demand (e.g., Lorde et al., 2016; Ridderstaat, Oduber, Croes, Nijkamp, and Martens, 2014; Buckley \& Foushee 2012; Goh 2012; Hadwen, Arthington, Boon, Taylor, \& Fellows 2011; Kulendran \& Dwyer, 2010; Yu, Schwartz, \& Walsh 2010; Scott \& Lemieux, 2009). The outcome of these studies suggests that climate is indeed a determinant of tourism demand, but there is still a need for further investigation in this area, as climate may be more comprehensive than rainfall, wind, humidity, temperature, and cloud coverage elements only. For instance, climate also includes phenomena such as El Niño or La Niña, which can be responsible for cyclical changes in the weather pattern (e.g., warmer or drier weather 
conditions). These events could also affect tourism demand, and, therefore, need to be studied in this context.

Besides climate, there could be other natural factors that could impact tourism demand. A key element of tourism is the required geographical mobility (Girard, 2017), as people have to go to the destination to consume the goods and services that encompass tourism demand (Croes, 2011). This mobilization could act as an essential driver for spreading infectious diseases, such as dengue and malaria, which, in epidemics form, could deter tourists from visiting a destination, with potential consequences for the local economy (Yoshikawa \& Kusriastuti, 2013). Furthermore, as destinations continue to develop their tourism business, this may further impact the available natural and human resources, for instance, (coastal) land that is being developed, with consequences for the aesthetic and environmental conditions as well as the quality of life ${ }^{8}$ of residents (Apostolopoulos \& Gayle, 2002). While these events can have severe consequences for every tourist destination, they may be particularly detrimental for small islands that rely heavily on tourism for their socio-economic development.

There is no generally accepted definition of a small island (Ridderstaat, 2015), but some restrictions include maximum population and size. For example, McElroy (2006) considered a small island as an area that has fewer than 1 million inhabitants, and smaller than 5,000 square kilometers. Other studies (e.g., Croes, 2011, and the Commonwealth Secretariat/World Bank Joint Task Force on Small States, (Secretariat (2000)) have considered a population smaller than 1.5 million people. Small Island Destinations (SIDs) have typically had a high level of tourism export concentration (De Albuquerque \& McElroy, 1992), and many small islands use tourism development as a growth strategy for higher economic and development

\footnotetext{
${ }^{8}$ Quality of life is defined here, in line with Sinha (2019), as the living conditions of each person or person in each area, resulting from the combined effect of a number of environmental, demographic, social, cultural and economic factors.
} 
performance (Croes, 2006). Thacker and Perreli (2012) found that specializing in tourism has helped to more than offset the negative impact of being a small island economy, as tourism has significantly contributed to lowering output volatility in many countries. According to the World Meteorological Organization (WMO), small island states are highly vulnerable to natural disasters and human-induced factors (WMO, 2017). The WMO further shows the significant exposure of small island states to weather- and climate-related natural and environmental hazards, such as floods and droughts, which cause death and injury and economic losses. Different small island states are in a tropical zone, where the climate is favorable for the transmission of tropical diseases such as dengue (UNFCCC, 2005). In recent years, tropical islands have witnessed high occurrences of vector- and water-borne diseases ${ }^{9}$ caused by changes in temperature and rainfall patterns, where events such as El Niño, droughts, and floods can affect the latter (UNFCCC, 2005).

For a long time, our understanding of the causal factors of tourism demand has been transfixed to a selective number of (economic) factors. Only in the last decade, the literature has been willing to propel an expansive approach by exploring more causes of tourism demand development. This study wishes to continue on this path, considering the socio-economic relevance of tourism, and advance our current knowledge on the driving forces of tourism demand, specifically from the stance of a SID.

\footnotetext{
9 Vector-borne diseases (VBDs) are a wide-ranging and varied group of diseases with the common denominator that the pathogen must be transmitted via an arthropod vector (Braks, Giglio, Tomassone, Sprong, \& Leslie, 2019).
} 


\subsection{Background}

\subsubsection{Economic and non-economic factors of tourism demand}

Many studies on the determinants of tourism demand have concentrated around a limited number of factors, mainly of an economic nature. Goh (2012) calls this the economic framework in explaining tourism demand, which considers economic factors such as income, price, substitution price, advertising, and supply constraints as the primary factors affecting tourism demand. Previous studies by Song et al. (2009) and Croes (2010) have also emphasized the dominance of economic factors in their lists of explanatory variables of tourism demand, citing income, (relative) prices for goods and services, marketing expenses, accommodation capacity, and exchange rates as critical determinants. The latter two studies do, however, mention some examples of non-economic factors, such as political situation, population growth, tastes, habits, and preferences, as well as one-off events (e.g., an oil crisis) and population growth, but it seems that the literature has only been willing to accommodate a static list of (economic) factors influencing tourism demand. According to Goh (2012), there is room to move beyond the orthodox tourism demand framework to include more salient factors (both economic and noneconomic) in the analysis.

\subsubsection{Climate as a non-economic factor for tourism demand}

Climate is of particular interest to the tourism industry, as it can cause seasonal fluctuations in tourism demand for destinations (Saverimuttu \& Varua, 2014). The UNWTO has defined climate $^{10}$ as the average weather for a specific location that impacts an array of environmental resources, which are critical

\footnotetext{
${ }^{10}$ According to the WMO and IPCC, the climate in the narrow sense is usually defined as 'average weather,' or more accurately, as the statistical description in terms of the average and variability of relevant quantities over a period ranging from months to thousands or millions of years. The classical period is 30 years, as defined by the World Meteorological Organization (WMO). These quantities are usually surface variables such as temperature, precipitation, and wind. The climate in the broader sense is the state, including a statistical description, of the climate system (http://www.wmo.int/pages/prog/wcp/ccl/faq/faq_doc_en.html).
} 
attractions for tourism, for example, snow conditions, wildlife productivity and biodiversity, and water levels and their quality (UNWTO \& UNEP 2008). Climate can be an even stronger determinant of tourism demand than some common economic factors, such as income, relative prices, and trade, as shown by Goh, Law, \& Mok (2008) for Hong-Kong.

Climate can act as a pull factor, mainly when it attracts visitors who expect favorable weather conditions at the destination (Scott, McBoyle, \& Schwartzentruber, 2004; Belén Gómez Martín, 2005; Kulendran \& Dwyer, 2010). As a push factor, the climate in the originating country can affect the decisions of people to travel abroad (Hamilton \& Tol, 2007). Hence, climate can act as both a pull and a push factor, which can affect the motivations of tourists on when and where to go on a holiday, and how they choose their destination of preference (Hamilton et al., 2005; Amelung, Nicholls, \& Viner, 2007). What is essential to understand is that climate is more comprehensive than its narrow sense of average weather (e.g., temperature, precipitation, wind speed, and cloud cover), and may, for example, also have a connection with significant features of the global circulation, such as the El Niño-Southern Oscillation (ENSO) and the North-Atlantic Oscillation (World Meteorological Organization, 2011). Consequently, studies should take a broader and more indepth investigation into climate as a non-economic factor of tourism demand.

\subsubsection{Infectious diseases affecting tourism demand}

Travel is part of man's DNA (Croes, 2011), but this activity is not free of risks. Even though tourism has become one of the fastest-growing economic segments, it is also vulnerable to perils from, for example, terrorism, wars, natural disasters, energy crises, economic recessions, and infectious diseases (Bonham, Edmonds \& Mak 2006; Butler, 2009; Garg, 2015; Strickland-Munro, Allison, \& Moore, 2009). Mainly the last risk is of interest to this study because tourists can get infected by diseases and can become the vectors for further infections, either at destinations or in their country of residence. 
Travel has been a strong force in the emergence of infectious diseases, ever since humans started to migrate, and continue to be the case in the current age of travel (Baker, 2015). Tourists have been at risk of getting infected by many sorts of (epidemic) diseases, including tuberculosis, influenza, noroviruses, meningococcus, sexually transmitted diseases (Wilson, 2008), malaria, dengue, yellow fever, ebola (Rosselló, Santana-Gallego, \& Awan, 2017), severe acute respiratory syndrome (SARS) (Wilder-Smith, 2006), and Lyme-disease (Donohou, Pennington-Grey, \& Omodior, 2015). It is more difficult to pinpoint precisely the effect of tourists as transmitters of infectious diseases since it is challenging to follow each individual and determine whether he or she has caused the infectious disease to another person in another tourist destination or country of residence of the tourist. However, there are some specific cases where researchers have established that travelers have infected locals at a destination or those in the country of origin of the travelers. For example, the outbreak of SARS (2002-2004) originated from a transmission infection in Hong Kong, when a physician from Guangdong (China) traveled and stayed at a hotel in Hong Kong, infecting other guests from Hong Kong, China, Vietnam, Singapore, and Canada (Abdullah, Thomas, McGhee, \& Morisky, 2004). These guests, on their turn, became the vectors of this disease and spread it as they returned to the respective countries, according to the latter authors. Moreover, in late September 2014, a man arriving a few days earlier from Liberia tested positive for the Ebola virus and later infected two nurses who were caring for this patient (Chevalier et al., 2014).

The risk of being infected by a contagious disease can also influence people's willingness to travel to these destinations. Tourists are generally disinclined to travel to destinations plagued by infectious diseases (Rosselló et al., 2017), and the mere perception of health risk by tourists in some areas of the world can be an essential predictor for avoiding those areas or changing their travel plans (Donohou et al., 2015). The latter can have negative 
implications for international travel and tourism activities. For instance, air travel to suspected areas of SARS decreased dramatically, while international tourism arrivals decreased by $1.2 \%$ in 2003 , mainly associated with this outbreak (Wilder-Smith, 2006). Similarly, the 2013 Ebola outbreak, which affected primarily Guinea, Sierra Leone, and Liberia, led many tourists to see the whole African continent as a risk, affecting demand for many African countries (WTTC, 2018b). As of the moment of writing this dissertation, the world is still in the grip of Coronavirus disease (COVID-19), that is caused by the severe acute respiratory syndrome coronavirus 2 (SARS-CoV-2). The COVID-19 pandemic, except for being a humanitarian crisis, has significantly disrupted the global economy. By the end of the first quarter of 2020, the COVID-19 pandemic had abruptly brought international travel to a standstill and significantly affected the tourism sector (UNCTAD, 2020).

\subsubsection{Environmental concerns in developing tourism demand}

The research community has generally recognized that both tourism and the environment are interconnected (e.g., Butler, 1991; Cater, 1995; Christou, Farmaki, Saveriades, \& Spanou, 2019; Green, Hunter, \& Moore, 1990; Inskeep, 1987; Pigram, 1980; Tang, 2015). Tourist destinations are unique, depending on the natural characteristics of the places, which only become available to tourists when transformed (or integrated) into products and services (a commodification process) (Romão, 2018). This commodification process can harm the environment (e.g., environmental pollution, ecological damage) if they are not well planned (Tang, 2015). For instance, the island of Mallorca, the largest of Spain's Balearic Islands, has experienced decades of overbuilding and environmental destruction that engendered, among others, environmental concerns on the island (Royle, 2009). Tourism to the Caribbean area has increased markedly since 2010 (CTO, 2014), making it the most tourism-dependent region in the world (Thomas, 2015). When tourists feel that an area is overbuilt, this can affect their experience and satisfaction with the 
destination, while at the same time diminishing the competitiveness of the latter (Cruz \& Zaragoza, 2019). In the case of Aruba a tourist exit survey of 584 surveys showed that between $45 \%$ and $55 \%$ of visitors would not return if there were a deterioration of the land, sea, or beach (Polaszek, Lacle, Beukering, \& Wolfs, 2018).

Societies have increasingly grown the awareness of these overdevelopments, and have initiated a re-evaluation of the methods of planning for future developments (Oduber, Ridderstaat, \& Martens, 2015). Nowadays, a greater emphasis is put on the need to preserve the environmental resources for future generations through the process of sustainable development (Apostolopoulos \& Gayle, 2002; Farquhar, Clayton \& Retalis, 2005). Sustainability is a widely recognized feature in tourism policy practice, and more and more attention is paid to the topic of sustainable tourism research (Guo, Jiang, \& Li, 2019). Tourism is a place-dependent activity that relies on the singularity of its territorial resources (Romão, 2018), and sustainable harmony with the environment is needed to keep destinations attractive to tourists.

To sum up, there is indeed an incentive to abandon the conventional framework of (economic) factors that impact tourism demand for destinations. The three discussed areas (climate, infectious diseases, and the environment) offer an excellent go-ahead to better understand the drivers of tourism demand. 


\subsection{Theoretical framework}

\subsubsection{General}

No single theory is capable of explaining tourism because the latter is a complex phenomenon (Ridderstaat. 2015). Still, several theories have been discussed in the literature to explain the particular contours of this activity. This study applies three theories, namely, Sustainable Development, Systems Theory, and Chaos Theory.

\subsubsection{Sustainable Development}

Sustainability may be conceptualized as being the crossroad for two schools of thought, i.e., development theory and environmental sustainability (Sharpley, 2000). While there are many theories of development (e.g., Classical and Neoclassical Economics, Keynesian Economics, Neoliberalism, Marxism, Socialism, Feminism, Critical Modernism), the overarching element is here to achieve a better life for everyone (Peet \& Hartwick, 2015). Conventional thinking about environmental degradation is that it stems from the Industrial Revolution (1880-1930), where industrial pollution, deforestation, land degradation were common, but environmental demeaning has accompanied humanity for almost the longevity of its existence (Mebratu, 1998). For example, archeological evidence from the Mediterranean region suggests that lead mining and smelting in around 7,000 BCE (Before the Common Era) have resulted in environmental contamination (Lessler, 1988). However, with the advent of the Industrial Revolution, the environmental degradation problems became more prominent (Kasa, 2008). It was Thomas Malthus (1766-1834), an English economist, who noted that the population growth if left unchecked, will outpace the physical means of subsistence (Ekelund \& Hébert, 2013; Malthus, 1788/1998), one of the first signals in modern time about the need for sustainable development.

The notion of sustainable growth became more explicitly suggested by Meadows, Meadows, Randers, \& Behrens (1972) in their book "Limits to 
Growth," which was the first report to the Club of Rome, an organization that cares for the future of humanity and strive to make a difference (https://www.clubofrome.org/about-us/). Almost at the same time, the United Nations Environment Program (UNEP) organized a conference in Stockholm (Sweden), where it considered "the need for a common outlook and for common principles to inspire and guide the peoples of the world in the preservation and enhancement of the human environment." (UNEP, 1972). While the declaration of this conference did not explicitly mention the term "sustainable development," it hinted towards that by its guidance towards preservation and enhancement of the human environment. While the Brundtland Report (1987) is often credited with popularizing and defining the concept of sustainable development in its report "Our Common Future", the contours of this concept were already becoming apparent with the publication of the "World Conservation Strategy: Living Resources for Sustainable Development" prepared by the International Union for Conservation of Nature and Natural Resources (1980): "Human beings, in their quest for economic development and the enjoyment of the riches of nature, must accept the reality of limited resources and the carrying capacity of ecosystems, and must take into account the needs of future generations" (International Union for Conservation of Nature and Natural Resources, 1980) (Brundtland, 1987). The Brundtland Report (1987) is more generic in its definition of sustainable development, where it expands the concept of development beyond the economic borders, and does not confine human needs to only the riches of nature as the report of the International Union of Conservation of Nature and Natural Resources (1980) does. Sustainable development is ultimately defined by the Brundtland Report (1987) as "development that meets the needs of the present without compromising the ability of future generations to meet their own needs." (Brundtland, 1987). 
Sustainable development has become a core global, regional, and local consideration (Harrington, 2016), and has received attention from governments, corporations, research laboratories and universities worldwide (Bettencourt \& Kaur, 2011). The concept of sustainable development remains dynamic, but, at the same time, it becomes more tangible when it comes to the policies needed to meet the needs of the present without compromising those of future generations. For example, in 2015, world leaders agreed on a new agenda to guide the world towards 2030, namely the Sustainable Development Goals (SDGs) (UNWTO, 2017b). Tourism is included in 3 of the 17 universal Goals, yet the cross-cutting nature of tourism makes it a useful tool to contribute to all 17 Goals (UNWTO, 2017b). The Paris Agreement of 2015 is another example, providing another step towards an effective and progressive response to the threat of climate change and its intrinsic effect on sustainable development (UNFCC, 2015).

There is no unique theory of sustainable development, as pointed out by Jenkins (2009). However, the idea of preservation seems to be a focal point in all theoretical thinking about sustainability. Sustainable development has evolved, focusing on the quality of the environment (environmental sustainability), human rights and equality as well as the preservation of cultural identity, respect for cultural diversity, race and religion (social sustainability), and the maintaining of natural, social, and human capital required for income and living standards (economic sustainability) (Klarin, 2018). This expanded emphasis shows that sustainability thinking has been moving beyond the confines of environmental protection, and we may have to think now about models of sustainable development, where the priority is the component that needs to be sustained (Jenkins, 2009). Tourism development seems to have embraced this model-based thinking when it comes to sustainable development. Besides caring for the environment (e.g., through more attention from destinations on the way this phenomenon is being developed, or the creation of 
niche markets such as ecotourism and wildlife tourism), there is also increased attention for preservation of cultural heritage, aesthetics, and well-being of the locals at the destination (e.g., geotourism, voluntourism) (Cook, Hsu, Taylor, 2018). Businesses, in general, have started to see that emphasizing social and environmental issues aside from the conventional notion of profit-making, the so-called Triple Bottom Line approach would simultaneously produce win/win/win outcomes for the corporation, society, and the planet (Willard, 2012). Tourism destinations have also recognized these benefits. Responsible tourism business owners nowadays not only emphasize the financial bottom line but also try to maximize the positive impacts on the area's social/cultural and environmental resources through the Triple Bottom Line approach (Cook et al., 2018). As such, sustainable development in tourism is also about the continuity of the business and the destination in the long run.

\subsubsection{Additional theories}

While Sustainable Development can explain the continuity of tourism in the long-run, it fails to explain recurring developments in tourism (e.g., seasonality and cycles of tourism demand) as well as the complexity of this phenomenon. For this reason, this study invokes two additional theories, i.e., Chaos Theory and Systems theory, to explain these characteristics of tourism demand.

\subsubsection{Chaos Theory}

Chaos can be defined as a condition of complex, unpredictable, and orderly disorder in which patterns of behavior unravel in irregular, but similar forms (Tetenbaum, 1998). Chaos theory offers an alternative approach to the deterministic view that leaves no room for randomness stemming from the occurrence of shock events. The latter concerns unique and unanticipated developments (Knoop, 2015) that can come from a myriad of unpredictable disturbances such as strikes, hurricanes, or foreign government actions (Bails \& Peppers, 1993). Chaos Theory can be used to describe the incidence and 
consequences of shocks, causing nonlinear systems that are difficult to predict (Nijkamp \& Reggiani, 1991;1995;1998). The theory implicates systems that are often unstable and where external effects and individual differences are seen as the driving forces behind variety, adaptation, and complementarity (Moreno 2010). According to Reggiani et al. (2001), the primary feature of Chaos Theory is that it tends to the instability of deterministic nonlinear dynamic systems that can sometimes yield seemingly random complex motions. Minor events may be just enough to cause a disruption of the stability and amplify the disturbance in such a way that the integrity and coherence of the system are endangered (Faulkner, 2001). The process of minor events leading to system instability has been coined the Butterfly Effect, with a more technical term of "sensitive dependence on initial conditions," where a chain of events starts with a point of crisis that could magnify small changes, making, for example, weather cycles unpredictable (Gleick, 2011). During periods of chaos, there is a loss of control which can threaten individuals or groups whose task it is to control the uncontrollable (McKercher, 1999).

Chaos Theory has been used to some extent to explain developments in tourism (e.g., Butler, 2009; Jurowsky, 2015; Faulkner, 2001; Faulkner \& Russel, 1997; McKercher, 1999; Russel \& Faulkner, 2004; Tang and Jang, 2010; Zahra \& Ryan, 2007). According to Mckercher (1999), much of the variability experienced in tourism can be explained by Chaos Theory. Tourism is an open system that is exposed to human (inter) actions and acts of nature, making it unlikely to follow a linear path for a sustained period (Ridderstaat, 2015). Chaos Theory offers a theoretical perspective to enlighten these nonlinearities in tourism development.

\subsubsection{Systems Theory}

A system is a set of interconnected elements in a way that they make their pattern of behavior over time and may be buffeted, constricted, triggered, or driven by outside forces (Meadows, 2008). The Systems Theory is a theoretical 
perspective that analyzes a phenomenon as a whole and not as merely the sum of fundamental parts (Mele, Pels, \& Polese 2010). According to the latter authors, one must focus on the interactions and the relationships between parts to understand an entity's organization, functioning, and outcomes. The tourism industry is an open system that is connected with components both inside and outside its confines (Hall and Lew, 2009; McDonald, 2009). For instance, it has a relationship with the environment, where the connection is both extractive and aesthetic (Carlsen, 1999). Tourism development is also linked to economic development as well as developments in the quality of life of residents (Croes, 2012; Ridderstaat et al., 2016a; 2016b). The tourism industry is also a fragile industry that is vulnerable to numerous shocks, including episodes of dangerous infectious diseases, terrorism, financial discrepancies, instable monetary forms, energy crises, and climate change (Bonham et al., 2006; Butler, 2009; Strickland-Munro et al., 2009). These examples of intricacies show that tourism is not a stand-alone development, but has connections with several factors of natural, economic, and human nature. These mutual relationships call for a systematic approach to tourism activities, which could be useful for problem-solving exercises in tourism research because it can accommodate social and environmental processes (Carlsen, 1999). Besides the latter author, other studies such as Leiper $(1979 ; 1990)$, McKercher, Mei, \& Tse (1979), Pyke et al. (2016), Scott \& Laws (2006), and Walle (1995) have also embraced the Systems Theory to understand and explain specific tourism activities, indicating some level of traction of this theory in the tourism literature.

\subsubsection{Connecting the theories to the study under review}

Sustainable Development is often inherent to a long-term stability perspective (e.g., United Nations, 2013; Janoušková, Hák, Necas, \& Moldan., 2019), which makes it less suitable to explain short-term developments in tourism demand, such as seasonal and cyclical variations (see the methodological foundations 
for a description of these developments). Tourism is an open and complex system that is affected by both human and natural factors, which cause it to follow a nonlinear development path (Ridderstaat, 2015). The interaction with other systems, such as climate, infectious diseases, and vegetation, described in this study, provides grounds for application of the Systems Theory. These interactions can affect human behavior, specifically tourism demand, causing developments in the seasonal and cyclical patterns in tourism. Chaos Theory can provide further explanation for these nonlinear outcomes as it reconciles the unpredictable results with distinctive patterns, where the outcomes do not return to the exact state in the end, but still create results characterized by simulable patterns (Levy, 1994). The latter fits both seasonal and cyclical patterns observed and studied in tourism.

Figure 1.1 shows the connection between the presented theories and the investigations ${ }^{11}$ covered in this study. The vegetation study falls within the scope of the sustainability framework as it looks mainly at the continuity of tourism in a long-term, setting. The latter aims to get a picture of the tourism component that needs to be preserved from a sustainable perspective. Climate as a determinant of tourism demand was studied using both seasonal and cyclical data, which are both considered here as short-term developments. From a seasonal perspective, the climate, tourism demand connection is an annually recurring event, which has more to do with the linkage between systems, in this case, the tourism and climate systems. From this perspective, the Systems Theory offers a better explanation of the findings than Chaos Theory. The latter explains nonlinear developments that will culminate in either a new normal or will return to its original condition. In this regard, the climate tourism-demand investigation using cyclical data can be explained by The Chaos theory. However, considering the interaction between different systems (tourism and climate), the systems theory can also provide explanatory

\footnotetext{
${ }^{11}$ These investigations will be further discussed in section 1.8 .
} 
power to the findings of this study. The study on the relationship between tourism demand and infectious disease considers seasonally recurring connections. The latter implies that the repetitive connection between these two constructs can be better explained by the Systems Theory. Taking all the studies into account, they fall under the theorems of Systems Theory, because the survival of tourism here is exposed to many parameters that are either anthropogenic(human) or natural.

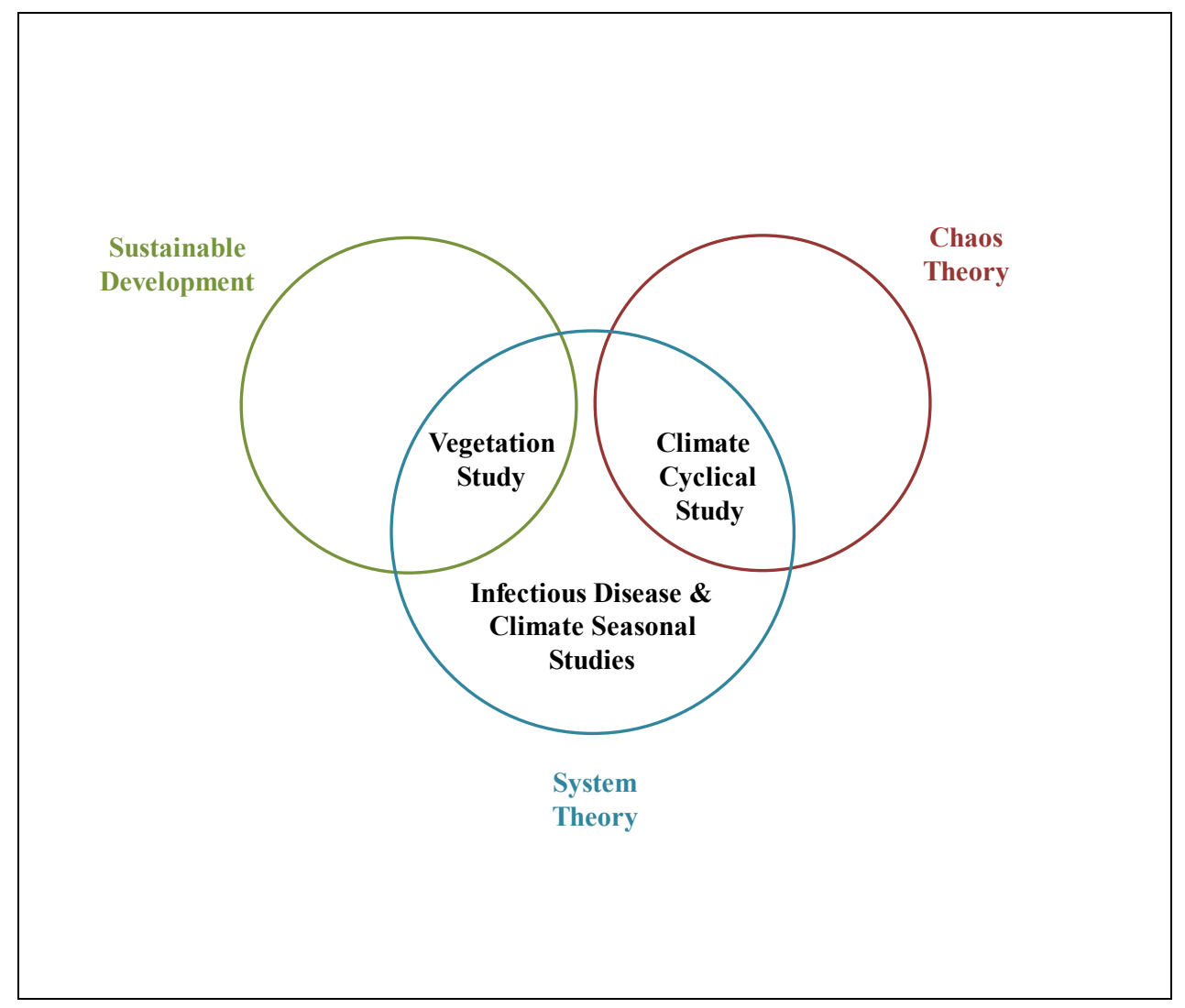

Figure 1.1 Theory linkages.

The previous indicates that a pluralistic strategy considering multiple theoretical frameworks offers a better understanding of developments in tourism than would be the case with a mono-theoretical approach. 


\subsection{Research questions}

This study will specifically investigate this following central question:

What is the connection between tourism demand in a SID and natural factors?

This question aims to provide an understanding of a possible bilateral relationship between tourism demand and natural factors, from the perspective of a SID. Answering this general question requires the formulation of four subquestions:

1. What is the connection between tourism demand development and vegetation in a SID?

2. Do cycles of climate affect tourism demand in a SID?

3. Do seasonal factors of climate affect tourism demand in a SID?

4. What is the connection between seasonal factors of tourism demand development and dengue in a SID?

These four questions are the basis for preparing the theoretical propositions and hypotheses, which will be discussed in the next section. 


\section{Small Island Developing States (SIDS)}

SIDS are a discrete group of developing countries facing specific social, economic, and environmental vulnerabilities. SIDS were furthermore recognized as a special case both for their environment and development at the United Nations Conference on Environment and Development (UNCED) in Rio de Janeiro, Brazil in 1992 (United Nations, 1994). SIDS can be found over different geographical regions namely, the Caribbean, the Pacific and the Atlantic, Indian Ocean, Mediterranean, and the South China Sea. In the Caribbean, these islands are considered as SIDS: Aruba, Anguilla, Antigua and Barbuda, Bahamas, Bermuda, British Virgin Islands, Cayman Islands, Cuba, Curacao, Dominica, Dominican Republic, Guadeloupe, Haiti, Jamaica, Martinique, Montserrat, Puerto Rico, Saint Maarten, Turks and Caicos, and the United States Virgin Islands (United Nations (2017). Small islands are forced to grow economically to take care of their population; they must use their resources in a sustainable manner, they must embrace standardization, but keep their identity to remain competitive (Croes, 2011).

\subsection{Hypotheses}

Hypotheses are possible explanations that account for the observations of the external world. The hypotheses describe cause and effect relationships between the proposed process (cause) and one's observations (the effect) (Gotelli \& Ellison, 2004). According to the latter authors, the scientific method can be considered as a technique to decide among hypotheses based on observations and predictions. This study presents three propositions, each consisting of several hypotheses that will be validated (or not) during this research. 
Proposition 1: In the short-run, tourism demand in Aruba is affected by seasonal and cyclical weather/climate patterns.

$\mathrm{H}_{1}$ : Seasonal climate elements in Aruba, the United States, and Venezuela, respectively, are essential in determining the seasonal variations of tourism demand from the United States and Venezuela.

$\mathrm{H}_{2}$ : Cyclic patterns of pull and push climate elements in Aruba, The Netherlands, the United States, and Venezuela affect the cyclical deviations of tourism demand for Aruba.

$\mathrm{H}_{3}$ : The El Nino Southern Oscillation (ENSO) and the North Atlantic Oscillation (NAO), affect the cyclical deviations of tourism demand for Aruba.

Proposition 2: The relationship between tourism demand and dengue outbreaks in Aruba is bilateral in the short run.

$\mathrm{H}_{4}$ : Seasonal tourism demand has an impact on seasonal dengue occurrences in Aruba.

$\mathrm{H}_{5}$ : Seasonal dengue occurrences have an impact on seasonal tourism demand for Aruba.

Proposition 3: The relationship between tourism demand and vegetation density fluctuations is bilateral in the long run.

$\mathrm{H}_{6}$ : Tourism demand for Aruba has a long-run impact on vegetation density fluctuations on the island.

$\mathrm{H}_{7}$ : Vegetation density fluctuations in Aruba have a long-run impact on tourism demand for the island. 


\subsection{Methodological foundations}

\subsubsection{A case study approach}

A case study is an empirical investigation of a contemporary phenomenon (i.e., the case) in-depth and within the real-world context (Yin, 2014). It is one of the methods in the pool of research strategies (e.g., experiment, survey, archival analysis) (Rowley, 2002), and is a popular research strategy in hospitality and tourism research (Altinay, Paraskevas, \& Jang, 2016). According to Yin (2014), individual case studies can contribute to scientific generalizations through the replication effect, where the mode of generalization is analytic (analytic generalization). The goal then is to expand and generalize theories, and not to enumerate frequencies (statistical generalizations). According to Eisenhardt and Graebner (2007), building theory from case studies is a research strategy that requires using one or more cases to create theoretical constructs, propositions, and/or midrange theory from case-based, empirical evidence. According to the latter authors, the central idea of this research method is to use cases as the foundation from which to develop theory inductively, based on replication logic, as each case stands on its own as an analytic unit. Case studies can center on different units of analysis, including individuals, small groups, organizations, partnerships, and even countries (Yin, 2014).

This investigation uses the island of Aruba as a case study for investigating the connection between tourism demand and natural factors in a Small Island Developing State and/or Small Island Destination. Aruba is an island in the West Indies in the Caribbean Sea near the Paraguaná Peninsula of Venezuela and an integral part of the Kingdom of the Netherlands (Figure 1.2). In 1986, Aruba separated from The Netherlands Antilles and had obtained separate status within the Kingdom of the Netherlands (IOCARIBE, 2017). With a population of around 112,000 in 2020, Aruba is the most densely populated region of the Kingdom of the Netherlands (CBS, 2020). Aruba has made impressive economic progress since 1986, with economic growth almost 
every year. The pre-COVID-19 estimates indicated a real growth of $2.8 \%$ for 2020 (CBA, 2020a). According to the WTTC, on Aruba, the total contribution of travel and tourism to the economy is $93.8 \%$ and labor $99.1 \%$ (WTTC, 2019b). Like most other Caribbean destinations, Aruba has two sectors of tourism: stay-over and cruise-ship tourism. The average expenditure of a cruise tourist is US\$ 121.94 (BREA, 2018) a day. In 1986, 73,386 cruise ship passengers visited Aruba. By 2019, the number increased to 832,001, a 1033.7\% increase (APA, 2020). In 2020 for the first six months, 255,384 cruise-ship passengers visited Aruba, a decrease of 41.3\% (APA, 2020). The decrease is mainly due to the COVID-19 crisis. With regards to stay-over tourism, most tourists arrive from the United States (WTTC, 2019b). The average expenditure a day is, respectively, US\$164.00 (Croes, Rivera, Pizam, Olson, Lee, \& Zhong, 2011). In the year 1986, Aruba had 181,200 stayover visitors, while in 2019, 1,117,660 a 516.8\% increase (CBA, 2020b, 2020c). In the first six months of 2020, stay-over visitors dropped by $60.3 \%$ from 2019 due to the COVID-19 pandemic (CBA, 2020c).

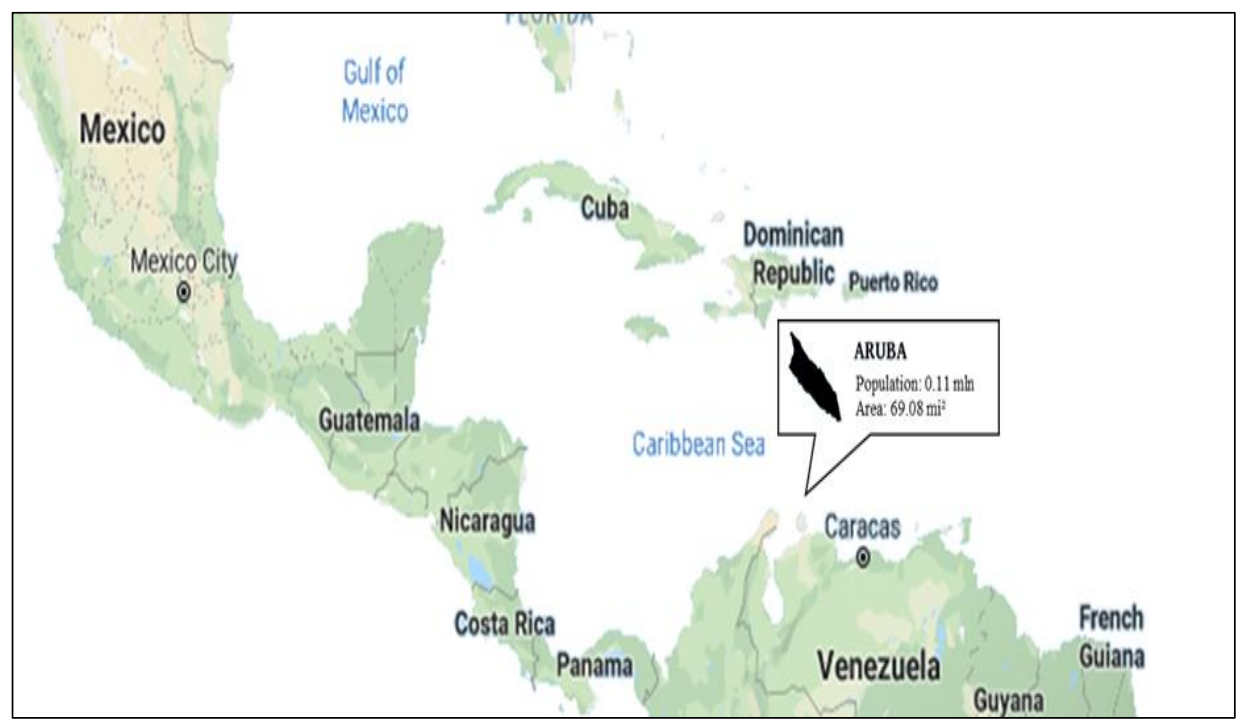

Figure 1.2 Case of study: Aruba. 
Climate change is a defining issue of our time (United Nations, 2019), and an essential consideration in tourism development. Tourism is a highly climatesensitive industry and also a growing contributor to changing trends in the weather (Scott, Gössling, \& Hall, 2012). Being a small island, Aruba is likely to be more at the receiving end of climate change. A study explicitly done for Aruba by the United Nations Economic Commission for Latin America and the Caribbean (ECLAC) in 2011 indicated that Aruba could lose more than 12 billion dollars due to a decline in tourism income by 2050 as a result of climate change. This effect implies that the island must take appropriate measures to adapt to and cope with the threat of climate change and so assure the continuity of its tourism industry (ECLAC, 2019). At the same time, Aruba needs to assume its part in the overall responsibility towards climate change. This study did not cover climate change as a specific topic of research but intends to consider this theme in near-term studies.

\subsubsection{Data decomposition}

The study investigates the connection between tourism demand and natural factors from both the short- and long-term perspectives. The reader is advised not to interpret the short and long term effects in a chronological sense, which means that the changes in the long term must follow those in the short-term. Both developments take place simultaneously, and short-term changes should be interpreted as deviations from long-term movements. The simultaneous occurrence of short-run and long-run effects could work in the same direction (e.g., both short and long-term effects will show increases) but could also mitigate each other (e.g., one will increase, while the other will show a decrease). The short- and long-run approach of the study requires the use of both monthly and annual time series data, the latter which are collected over some time (Brooks, 2011). To further emphasize the short-term factors, the study decomposed the monthly data to eliminate some unnecessary elements. To elaborate on the latter, short-term time series (e.g., monthly data 
observations) consist of four different elements, i.e., a trend, cycle, seasonal, and irregular factors (Bails \& Peppers, 1993; Keating \& Wilson, 2019; Makridakis, Wheelwright, \& McGee, 1983). The trend represents the long-term (multi-annual) movements in the level of the data (Keating \& Wilson, 2019), and can be influenced by factors such as changes in consumer preferences, changes in income, shifts in the population, technological advances to name a few (Bails \& Peppers, 1993). Cycles are wavelike variations around the trend, and their moment of occurrence cannot be determined with exactitude (Keating $\&$ Wilson, 2019). Examples of cyclical events are the occurrence of El Niño, and La Niña phenomena discussed earlier. Seasonal factors are recurring events that often occur during specific months of the year, but not necessarily in an exact manner each year (Bails \& Peppers, 1993). A good example is tourism, where tourists are, for instance, more inclined to travel during Winter than in other months of the year, but the magnitude of their travel can differ each year during this season. Another example is the weather season (Spring, Summer, Fall, Winter), where the intensity of these events can vary year after year. Irregular factors are those elements in the data that concern random or erratic variations due to incidental unforeseen events such a hurricane, a labor strike, and Ebola outbreak, or a terrorist attack (Bails \& Peppers, 1993; Keating \& Wilson, 2019). The study used different data decomposition techniques (e.g., Census X12, and wavelet transformation) to determine the seasonal and cyclical factors relevant to the individual investigations detailed in Chapters two to five.

\subsubsection{Data testing and relationship determinations}

Besides data decomposition, the study also applied different forms of data transformations (mostly logarithm calculations) to limit the variability of the data. The data were also investigated via graphical inspections and calculations of their descriptive statistics to assess for the presence of outlier observations. Additionally, the data were tested for stationarity, the latter which, loosely 
speaking, entails that the mean and variance of the data do not vary systematically over time (Gujarati \& Porter, 2009). Ultimately, the study pursued the research objectives by applying different models of regression to assess possible dependency relationships, considering the statistical appropriateness of the estimated equations. Overall, the study attempted, to some extent, benefit from the rich arsenal of data testing and relationassessment options available in time series analysis.

\subsection{Research significance}

This study contributes in several ways to the body of tourism literature. First, the study provides new ideas on analyzing the connection between natural factors and seasonal and cyclical developments in tourism demand. While the relationship between climate factors and tourism demand was deemed unilateral in this investigation (climate $\rightarrow$ tourism demand), the study considered a more extended approach when it comes to the relationship between, on the one hand, infectious diseases and vegetation, and tourism demand on the other hand. The bilateral consideration implies that tourism demand is more than a passive factor, and can impact the same factor that influences this phenomenon. Second, this investigation simultaneously analyzed the impact of both pull and push climate factors on cyclical and seasonal tourism demand movements on a small island, which, as far as has been assessed, is not common when it comes to time-series based studies on this relationship. Third, past studies on dengue, although suggestive, were often inadequate to provide how dengue influences seasonal patterns of tourism demand in SIDs. Fourth, as far as could be assessed, only a few numbers of studies were conducted using the normalized difference vegetation index (NDVI) to monitor the gradient in vegetation due to tourism growth on a SID. These destinations often depend on tourism for their development (Croes, 2011), where their natural capital is an essential asset for their attractiveness. Finally, this study contributes to the theory-building process by providing 
several theoretical propositions following the case study approach applied in the individual studies discussed in Chapters two to five. For example, push and pull climate factors can affect short-term tourism demand (Chapter two), and vegetation density can be affected by the demand of tourists for a destination (Chapter five).

\subsection{Outline of the study}

Figure 1.3 provides an overview of the structure of the study. The investigation is divided into three sections.

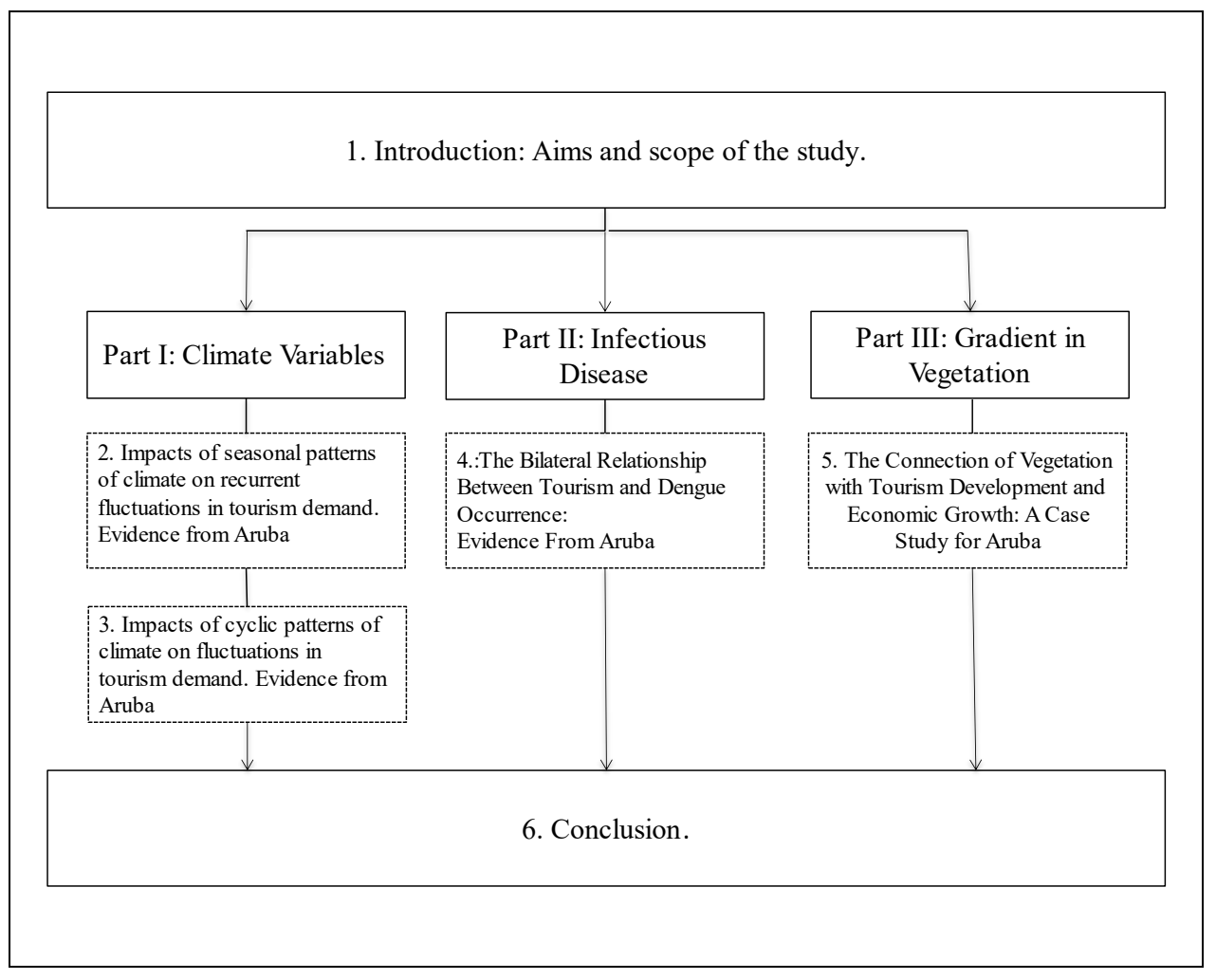

Figure 1.3 Study outline. 
Section I (Climate) dwells more into the relationship between seasonal and cyclical climate fluctuations and tourism demand. Chapter two examines the impact of seasonal climate patterns on recurring fluctuations in tourism demand from the United States and Venezuela to Aruba, considering both pull and push climate factors (rain, temperature, wind, and cloud cover). Chapter three assesses the effects of cyclical climate patterns on fluctuations in the US, Dutch, and Venezuelan demand for Aruba, emphasizing again pull and push climatological elements (rainfall, temperature, wind). Part II (Infectious disease) examines the passive and active roles of tourism demand when it comes to its connection with infectious diseases. Specifically, the study in Chapter four examines a possible link between the occurrence of dengue and tourism demand for Aruba from a bilateral standpoint, which expands the role of tourism demand beyond the receiving end. Part III studies land-use change, i.e., the gradient change of vegetation resulting from tourism development. Chapter five explores the bilateral relationship between vegetation and tourism development, allowing for the possibility of active roles for both constructs. Chapter six discusses the conclusion of this study and synthesizes the findings of the investigations presented in chapters two to five. Moreover, this chapter presents the theoretical propositions and managerial implications, as well as limitations and future research plan stemming from the conducted investigations. The research in Chapters two to five have been previously published in double-blind peer-reviewed journals.

The next chapters will detail on the presented outline in this section. 


\section{References}

Abdullah, A. S. M., Thomas, G. N., McGhee, S. M., \& Morisky, D. E. (2004). Impact of severe acute respiratory syndrome (SARS) on travel and population mobility: implications for travel medicine practitioners. Journal of travel medicine, 11(2), 107-111.

Altinay, L., Paraskevas, A., \& Jang, S. S. (2016). Planning research in hospitality and tourism. Oxon: Routledge.

Amelung, B., Nicholls, S., \& Viner, D. (2007). Implications of Global Climate Change for Tourism Flows and Seasonality. Journal of Travel Research, 45, 285-296.

Apostolopoulos, Y. (1996). Introduction: reinventing the sociology of tourism. The sociology of tourism: Theoretical and empirical investigations.

Apostolopoulos, Y., \& Gayle, D. (2002). Island Tourism and Sustainable Development: Caribbean, Pacific and Mediterranean Experiences. Santa Barbara: Greenwood Publishing Group.

APA. (2020, September 11). Detailed Cruise Data. Retrieved September 11, 2020, from Detailed Cruise Data:

https://www.arubaports.com/main/statistics/.

Baker, D. M. A. (2015). Tourism and the Health Effects of Infectious Diseases: Are There Potential Risks for Tourists?. International Journal of Safety and Security in Tourism and Hospitality, 1(12), 1.

Bails, D., \& Peppers, L. C. (1993). Business fluctuations: forecasting techniques and applications. New Jersey: Prentice-Hall.

Belén Gómez Martín, M. (2005). Weather, climate and tourism, A geographical perspective. Annals of Tourism Research, 32(3), 571591.

Bettencourt, L. M., \& Kaur, J. (2011). Evolution and structure of sustainability science.Proceedings of the National Academy of Sciences, 108(49), 19540-19545.

Bonham, C., Edmonds, C., \& Mak, J. (2006). The impact of 9/11 and other terrible global events on tourism in the United States and Hawaii. Journal of Travel Research, 45, 99-110.

Braks, M., Giglio, G., Tomassone, L., Sprong, H., \& Leslie, T. (2019). Making vector-borne disease surveillance work: New opportunities from the SDG perspectives. Frontiers in veterinary science, 6, 232.

BREA. (2018). Economic Contribution of Cruise Tourism to the Destination Economies. Phillipsburg: Business Research and Economics Advisors. Brooks, C. (2011). Introductory econometrics for finance. Cambridge: Cambridge University Press.

Brundtland, G. H. (1987). Report of the World Commission on environment and development:" our common future.". United Nations.

Buckley, L. B., \& Foushee, M. S. (2012). Footprints of climate change in US national park visitation. International Journal of Biometeorology, 56(6), 1173-1177. 
Burrows, C. J. (1990). Processes of vegetation change. In Processes of Vegetation Change (pp.359-419). Springer, Dordrecht.

Butler, R. (1991). Tourism, environment and sustainable development. Environmental Conservation, 18(3), 201-209.

Butler, R. (2009). Tourism in the future: Cycles, waves or wheels? Futures, 41(6), 346-352.

Carlsen, J. (1999). A Systems Approach to Island Tourism Destination

Management. Systems Research and Behavioral Science, 16(4), 321.

Cater, E. (1995). Environmental contradictions in sustainable tourism. The

Geographical Journal, 161(1), 21-28.

CBA. (2019). Annual Statistical Digest 2019. Oranjestad: Central Bank of Aruba.

CBA. (2020a). Economic Outlook July 2020. Oranjestad: Central Bank of Aruba.

CBA. (2020b). Annual Statistical Digest 2019. Oranjestad: Central Bank Aruba.

CBA. (2020c). Statistical Data-Monthly Tables. Retrieved September 15, 2020, from Central Bank of Aruba:

https://www.cbaruba.org/cba/do/getPage/page/statistical-monthlytables.html.

CBS. (2020). Quarterly Demographic Bulletin, 1st Quarter 2020. Oranjestad: Central Bureau Statistics of Aruba.

Chevalier, M. S., Chung, W., Smith, J., Weil, L. M., Hughes, S. M., Joyner, S. N., ... \& Threadgill, H. (2014). Ebola virus disease cluster in the United States-Dallas county, Texas, 2014. MMWR. Morbidity and mortality weekly report, 63(46), 1087.

Christou, P., Farmaki, A., Saveriades, A., \& Spanou, E. (2019). The "genius loci" of places that experience intense tourism development. Tourism Management Perspectives, 30, 19-32.

Cook, R., Hsu, C., Taylor, L. (2018). Tourism: The business of hospitality and travel. New York: Pearson.

Croes, R. (2006). A paradigm shift to a new strategy for small island economies: Embracing demand side economics for value enhancement and long term economic stability. Tourism Management, 27(3), 453-465.

Croes, R. (2010). Anatomy of demand in international tourism: The case of Aruba. Saarbrucken: Lambert Academic Publication.

Croes, R. (2011). Small island paradox: Tourism specialization as a potential solution. Lap Lambert Academic Publ.

Croes, R., Rivera, M., Pizam, A., Olson, E., Lee, S., \& Zhong, Y. (2011).

Winning the future: Strategic Plan for the development of Tourism.

Croes, R. (2012). Assessing Tourism Development from Sen's Capability Approach. Journal of Travel Research, 51(5), 542-554. 
Cruz, M., \& Zaragoza, M. (2019). Analysis of the accommodation density in coastal tourism areas of insular destinations from the perspective of overtourism. Sustainability, 11, 3031, DOI:10.3390/su11113031.

CTO (2014). Quarterly Reviews and Prospects. "Caribbean Tourism-State of the Industry 2011.". Retrieved August 10, 2014, from http://www.onecaribbean.org/.

De Albuquerque, K., \& McElroy, J. L. (1992). Caribbean small-island tourism styles and sustainable strategies. Environmental Management, 16(5), 619-632.

Donohou, H., Pennington-Gray, L., \& Omodior, O. (2015). Lyme disease: Current issues, implications, and recommendations for tourism management. Tourism Management, 46, 408-418.

ECLAC. (2011). The Economics of Climate Change in the Caribbean Summary Report 2011. Port-of-Spain, Trinidad, and Tobago: ECLAC.

Eisenhardt, K., \& Graebner, M. (2007). Theory Building from Cases: Opportunities and Challenges. Academy of Management Journal, 50(1), 25-32.

Ekelund, Jr, R. B., \& Hébert, R. F. (2013). A history of economic theory and method. Illinois: Waveland Press.

Faulkner, B., \& Russell, R. (1997). Chaos and complexity in tourism: In search of a new perspective. Pacific Tourism Review, 1(2), 93-102.

Faulkner, B. (2001). Towards a framework for tourism disaster management. Tourism Management, 22(2), 135-147.

Farquhar, C., Clayton, C., \& Retalis, A. (2005). A Satellite Remote Sensing to Aid Sustainable Development: A Case Study of Skiathos Island, Greece. In WSEAS/IASME International Conference on Energy, Environment, Ecosystems and Sustainable Development,1-6.

Frechlin, D. (1996). Practical tourism forecasting. Oxford: ButterworthHeinemann.

Frechlin, D. (2001). Forecasting tourism demand: Methods and strategies. Oxford: Butterworth Heinemann.

Garg, A. (2015). Travel risks vs. tourist decision making: A tourist perspective. International Journal of Hospitality \& Tourism Systems, 8(1), 1-9.

Goeldner, C., \& Ritchie, J. (2012). Tourism: principles, practices, philosophies. John Wiley and Sons, Inc.

Girard, L. (2017). From linear to circular tourism. Aestimum, 70.

Gleick, J. (2011). Chaos: Making a new science. Open Road Media.

Goh, C., Law, R., \& Mok, H. M. K. (2008). Analyzing and forecasting tourism demand: A rough sets approach. Journal of Travel Research, 46(3), 327-338.

Goh, C. (2012). Exploring impact of climate on tourism demand. Annals of Tourism Research. Annals of Tourism Research, 39(4), 1859-1883.

Gotelli, N., \& Ellison, G. (2004). A primer of ecological statistics.

Massachusetts, USA: Sinauer. 
Guo, Y., Jiang, J., \& Li, S. (2019). A sustainable tourism policy research review. Sustainability, 11, 3187; DOI:10.3390/su11113187.

Gujarati, D., \& Porter, D. (2009). Basic Econometrics. McGraw-Hill, New York.

Green, H., Hunter, C., \& Moore, B. (1990). Assessing the environmental impact of tourism development: A Delphi technique. Tourism Management, June 1990.

Hadwen, W. L., Arthington, A. H., Boon, P. I., Taylor, B., \& Fellows, C. S. (2011). Do climatic or institutional factors drive seasonal patterns of tourism visitation to protected areas across diverse climate zones in eastern Australia?. Tourism Geographies, 13(2), 187-208.

Hall, C. M., \& Lew, A. A. (2009). Understanding and managing tourism impacts: An integrated approach. Routledge.

Hamilton, J., Maddison, D., \& Tol, R. (2005). Climate Change and International Tourism: A Simulation Study. Global Environmental Change, 15, 253-266.

Hamilton, J., \& Tol, R. (2007). The Impact of Climate Change on Tourism in Germany, the UK and Ireland: A Simulation Study. Regional Environment Change, 7, 161-172.

Harrington, L. M. B. (2016). Sustainability theory and conceptual considerations: a review of key ideas for sustainability, and the rural context. Papers in Applied Geography, 2(4), 365-382.

Hermans, B., \& Kosters, L. (2019). Beroepsbevolking op de NederlandsCaribische eilanden. Den Haag: CBS Nederland.

IOCARIBE (2017). IOCARIBE. Retrieved June 1, 2017, from http://iocaribe.ioc-unesco.org/member-states?id=20.

Inskeep, E. (1987). Environmental planning for tourism. Annals of Tourism Research, 14, 118135.

International Union for Conservation of Nature, \& World Wildlife Fund. (1980). World conservation strategy: Living resource conservation for sustainable development. Gland,Switzerland: IUCN.

Janoušková, S., Hák, T., Necas, V., \& Moldan (2019). Sustainable Development-A Poorly Communicated Concept by Mass Media. Another Challenge for SDGs? Sustainability, 11, 1-20.

Jenkins, W. (2009). Sustainability theory. Berkshire encyclopedia of sustainability: The spirit of sustainability, 380-384.

Jurowski, C. (2015). Theoretical Perspectives on Tourism and Sustainable Community Development. Demystifying Theories in Tourism Research, CAB International, 128-146.

Kasa, S. (2008). Industrial revolutions and environmental problems. In Ostreng, W. (Ed.), Confluence: interdisciplinary Communication 2007/2008. Oslo: Centre for Advanced Study.

Keating, B., \& Wilson, J. (2019). Forecasting and Predictive Analytics. New York: McGraw Hill/Irwin. 
Klarin, T. (2018). The Concept of Sustainable Development: From its Beginning to the Contemporary Issues. Zagreb International Review of Economics \& Business, 21(1), 67-94.

Knoop, T. A. (2015). Business Cycle Economics: Understanding Recessions and Depressions from Boom to Bust. California: ABC-CLIO, Inc.

Kulendran, N., \& Dwyer, L. (2010). Seasonal variation versus climate variation for Australian Tourism. CRC for Sustainable Tourism Pty Limited.

Levy, D. (1994). Chaos theory and strategy: Theory, application, and managerial implications. Strategic Management Journal. 15, 167-178.

Leiper, N. (1979). The framework of tourism: Towards a definition of tourism, tourist, and the tourist industry. Annals of tourism research, 6(4), 390407.

Leiper, N. (1990). Tourist attraction systems. Annals of tourism research, 17(3), 367-384.

Lessler, M. (1988). Lead and lead poisoning from antiquity to modern times. Ohio Journal of Science, 88(3), 78-84.

Lorde, T., Li, G., \& Airey, D. (2016). Modeling Caribbean tourism demand: an augmented gravity approach. Journal of Travel Research, 55(7), 946956.

Lundberg, D., Krishnamoorthy, M., \& Stavenga, M. (1995). Tourism Economics. John Wiley and sons.

Makridakis, S., Wheelwright, S., \& McGee, V. (1983). Forecasting: Methods and Applications. John Wiley \& Sons, Inc.

Malthus, T. (1798/1998). An Essay on the Principle of Population. Electronic Scholarly Publishing Project (http://www.esp.org).

McDonald, J. R. (2009). Complexity science: an alternative world view for understanding sustainable tourism development. Journal of Sustainable Tourism, 17(4), 455-471.

McElroy, J. L. (2006). Small island tourist economies across the life cycle. Asia Pacific Viewpoint, 47(1), 61-77.

McKercher, B., Mei, W. S., \& Tse, T. S. (2006). Are short duration cultural festivals tourist attractions?. Journal of Sustainable Tourism, 14(1), 55-66.

McKercher, B. (1999). A chaos approach to tourism. Tourism Management, 20(4), 425-434.

Mebratu, D. (1998). Sustainability and sustainable development: historical and conceptual review. Environmental impact assessment review, 18(6), 493-520.

Mele, C., Pels, J., \& Polese, F. (2010). A brief review of systems theories and their managerial applications. Service Science, 2(1-2), 126-135.

Meadows, D. H., Meadows, D. L., Randers, J., \& Behrens, W. W. (1972). The limits to growth. New York, 102, 27. 
Meadows, D. H. (2008). Thinking in systems: A primer. Chelsea green publishing.

Moore, W. R. (2010). The impact of climate change on Caribbean tourism demand. Current Issues in Tourism, 13(5), 495-505.

Moreno, A. (2010). Climate Change and Tourism Impacts and Vulnerability in Coastal Europe. Maastricht: Universitaire Pers Maastricht.

Nijkamp, P., \& Reggiani, A. (1991). Chaos theory and spatial dynamics. Journal of transport economics and policy, 81-96.

Nijkamp, P., \& Reggiani, A. (1995). Nonlinear evolution of dynamic spatial systems. The relevance of chaos and ecologically-based models. Regional Science and Urban Economics, 25(2), 183-210.

Nijkamp, P., \& Reggiani, A. (1998). The economics of complex spatial systems.

Oduber, M., Ridderstaat, J., \& Martens, P. (2015). The connection of vegetation with tourism development and economic growth: A case study for Aruba. Journal of Environmental Science and Engineering, 4, 420-431.

Peet, R., \& Hartwick, E. (2015). Theories of development: Contentions, arguments, alternatives. New York: The Guilford Press.

Pigram, J. (1980). Environmental implications of tourism development. Annals of Tourism Research, VII(4), 554-583.

Polaszek, T., Lacle, F., Beukering, van, P., \& Wolfs, E. (2018). TEEB ArubaThe Economics of Ecosystems and Biodiversity. Wolfs Company.

Pyke, S., Hartwell, H., Blake, A., \& Hemingway, A. (2016). Exploring wellbeing as a tourism product resource. Tourism Management, 55, 94-105.

Ridderstaat, J. (2007). The Lago story: The compelling story of an oil company on the island of Aruba. Oranjestad: Editorial Charuba.

Ridderstaat, J., Oduber, M., Croes, R., Nijkamp, P., \& Martens, P. (2014). Impacts of seasonal patterns of climate on recurrent fluctuations in tourism demand: Evidence from Aruba. Tourism Management, 41, 245-256.

Ridderstaat, J. R. (2015). Studies on determinants of tourism demand dynamics in a small islanddestination. The case of Aruba (Ph. D. thesis, Economics and Business Administration, Vrije Universiteit Amsterdam).

Ridderstaat, J., Croes, R., \& Nijkamp, P. (2016a). A two-way causal chain between tourism development and quality of life in a small island destination: an empirical analysis. Journal of Sustainable Tourism, 24(10), 1461-1479.

Ridderstaat, J., Croes, R., \& Nijkamp, P. (2016b). The tourism developmentquality of life nexus in a small island destination. Journal of Travel Research, 55(1), 79-94.

Reggiani, A., Nijkamp, P., \& Sabella, E. (2001). New advances in spatial network modelling: Towards evolutionary algorithms. European Journal of Operational Research, 128(2), 385-401. 
Romão, J. (2018). Tourism, territory and sustainable development: Theoretical foundations and empirical applications in Japan and Europe. Singapore: Springer.

Rosselló, G., Santana-Gallegos, M, \& Awan, W. (2017). Infectious disease and international tourism demand. Health Policy and Planning, 32, 538548.

Rowley, J. (2002). Using case studies in research. Management research news, 25(1), 16-27.

Royle, S. (2009). Tourism changes on a Mediterranean island: Experiences from Mallorca. Island Studies Journal, 4(2), 225-240.

Russell, R., \& Faulkner, B. (2004). Entrepreneurship, chaos and the tourism area lifecycle. Annals of tourism research, 31(3), 556-579.

Saverimuttu, V., \& Varua, M. E. (2014). Climate variability in the origin countries as a "push" factor on tourist arrivals in the Philippines. Asia Pacific Journal of Tourism Research, 19(7), 846-857.

Schubert, S. F., \& Brida, J. G. (2011). Dynamic model of economic growth in a small tourism driven economy. In Tourism Economics (pp. 149-168). Physica-Verlag HD.

Scott, D., Lemieux, C., \& Malone, L. (2011). Climate services to support sustainable tourism and adaptation to climate change. Climate Research, 47(1/2), 111-122.

Scott, D., Gössling, S., \& Hall, C. M. (2012). International tourism and climate change. Wiley Interdisciplinary Reviews: Climate Change, 3(3), 213232.

Scott, D., McBoyle, G., \& Schwartzentruber, M. (2004). Climate Change and The Distribution of Climatic Resources for Tourism in North America. Climate Research, 27, 105-117.

Scott, N., \& Laws, E. (2006). Tourism crises and disasters: Enhancing understanding of system effects. Journal of Travel \& Tourism Marketing, 19(2-3), 149-158.

Secretariat, (2000). World Bank Joint Task Force on Small States (2000). In Small States: meeting challenges in the global economy.

Sharpley, R. (2000). Tourism and sustainable development: Exploring the theoretical divide. Journal of Sustainable Tourism, 8(1), 1-19.

Sinha, B. R. K. (Ed.). (2019). Multidimensional Approach to Quality of Life Issues: A Spatial Analysis. Springer Nature.

Song, H., Witt, S., \& Li, G. (2009). The advanced econometrics of tourism demand. New York: Routledge.

Stoddard, J., Pollard, C., \& Evans, M. (2012). The triple bottom line: A framework for sustainable tourism development. International Journal of Hospitality \& Tourism Administration, 233-258.

Strickland-Munro, J., Allison, H., \& Moore, S. (2009). Using resilience concepts to investigate the impacts of protected area tourism on communities. Annals of Tourism Research, 37(2), 499-519. 
Tang, L., \& Jang, S. (2010). The evolution from transportation to tourism: The case of the New York canal system. Tourism Geographies, 12(3), 435459.

Tang, Z. (2015). An integrated approach to evaluating the coupling coordination between tourism and the environment. Tourism Management, 46, 11-19.

Tetenbaum, T. J. (1998). Shifting paradigms: From Newton to Chaos. Organizational Dynamics, 26(4), 21-32.

Thacker, N., Acevedo, S., \& Perrelli, R. (2012). Caribbean Growth in an International Perspective: The Role of Tourism and Size.

Thomas, D. (2015). The Caribbean tourism industry in the 21st century: An assessment. Kimberly Green Latin American and Caribbean Center working paper $3 / 2015$.

Vanhove, N. (2005). The Economics of Tourism Destinations. Elsevier In.

Walle, A. H. (1995). Business ethics and tourism: From micro to macro perspectives. Tourism Management, 16(4), 263-268.

Wilder-Smith, A. (2006). The severe acute respiratory syndrome: Impact on travel and tourism. Travel Medicine and Infectious Disease, 4, 53-60.

Willard, B. (2012). The new sustainability advantage: Seven business case benefits of a Triple Bottom Line. British Columbia: New Society Publishers.

Wilson, M. (2008). Global travel and emerging infections. IOM Forum on Microbial Threats, December 16, 2008.

World Meteorological Organization (2011). Guide to climatological practices. Geneva: World Meteorological Organization.

WMO (2017). SIDS - Saving paradise - Ensuring sustainable development.

Retrieved June 1, 2017, from

https://public.wmo.int/en/resources/library/sids-saving-paradiseensuring-sustainable-development.

WTTC (2018a). Travel and tourism power and performance report. World Travel \& Tourism Council.

WTTC (2018b). Impact of the Ebola epidemic on travel \& tourism. World Travel \& Tourism Council.

WTTC (2019a). Top 20 countries. World Travel \& Tourism Council.

WTTC (2019b). Aruba, 2019 annual research: Key highlights. World Travel \& Tourism Council.

UNEP. (1972). Declaration of the United Nations conference on the human environment.

United Nations (1994). A/CONF.167/9 Report Of The Global Conference On The Sustainable Development Of Small Island Developing States.

Retrieved June 1, 2017, from http://www.un.org/documents/ga/conf167/aconf167-9.htm.

United Nations (2013). World economic and social survey: Sustainable development challenges. New York: United Nations. 
United Nations (2017). Retrieved June 1, 2017, from https://sustainabledevelopment.un.org/topics/sids/list.

United Nations (2019). The heat is on: Taking stock of global climate ambitions. New York: United Nations.

UNCTAD. (2020). Covid-19 and tourism: assessing the economic consequences. Retrieved October 1, 2020, from https://unctad.org/system/files/official-ocument/ditcinf2020d3_en.pdf.

UNFCCC (2015). Adoption of the Paris Agreement. Report No. FCCC/CP/2015/L.9/Rev.1, http://unfccc.int/resource/docs/2015/cop21/eng/109r01.pdf.

UNFCCC (2005) climate change, small island developing States. Issued by the CLIMATE CHANGE SECRETARIAT (UNFCCC), Bonn, Germany.

UNWTO, \& UNEP. (2008). Climate Change and Tourism, Responding to Global Challenges.

UNWTO (2017a). UNWTO Tourism Highlights: 2017 Edition. Retrieved June 1,2018 , from https://www.e-unwto.org/doi/pdf/10.18111/9789284419029.

UNWTO (2017b). UNWTO Annual Report 2016. Retrieved June 1, 2017, from http://media.unwto.org/publication/unwto-annual-report-2016.

UNWTO (2019). International Tourism Highlights: 2019 Edition. UNWTO Yin, R. (2014). Case study research. Los Angeles: Sage.

Yoshikawa, M. J., \& Kusriastuti, R. (2013). Surge of dengue virus infection and chikungunya Fever in Bali in 2010: the burden of mosquito-borne infectious diseases in a tourist destination. Tropical medicine and health, 2011-05.

Yu, G., Schwartz, Z., \& Walsh, J. E. (2010). Climate change and tourism seasonality. Journal of Tourism, 11(2).

Zahra, A., \& Ryan, C. (2007). From chaos to cohesion-Complexity in tourism structures: An analysis of New Zealand's regional tourism organizations. Tourism Management, 28(3), 854-862. 


\section{Part I:}

Climate Variables 


\title{
2. Impacts of seasonal patterns of climate on recurrent fluctuations in
}

tourism demand. Evidence from Aruba ${ }^{l}$

\begin{abstract}
This study estimates the effect of seasonal patterns of pull and push climate elements (rainfall, temperature, wind, and cloud coverage) on recurrent fluctuations in tourism demand from the United States (USA) and Venezuela to Aruba. The seasonal patterns were first isolated from the series using the Census X-12 decomposition method, after which the analysis included panel data unit root testing, panel data regression, and Euclidean distance calculation. The results show that both pull and push seasonal factors of climate were relevant in determining the seasonal variations in tourism demand from both countries. The study derives two theoretical propositions: (1) climate is a significant push and pull factor affecting tourism demand; and (2) tourism demand and climate are bounded by intertemporal climate constraints.
\end{abstract}

Keywords: seasonality, tourism demand, climate, panel regression, small island, Aruba

1. This chapter is based on: Ridderstaat, J., Oduber, M., Croes, R., Nijkamp, P., \& Martens, P. (2014). Impacts of seasonal patterns of climate on recurrent fluctuations in tourism demand: Evidence from Aruba Tourism Management, $41,245-256$. 


\subsection{Introduction}

The purpose of the study is to investigate how seasonal patterns of climate variables influence tourism demand seasonality in small island destinations. 'Climate' is the prevailing condition of the atmosphere drawn from long periods of observation, contrary to the term 'weather,' which is the state of the atmosphere at a given time and in a given place (Belén Gómez Martín, 2005). More specifically, according to the WMO and IPCC, the climate in the narrow sense is usually defined as 'average weather,' or more accurately, as the statistical description in terms of the average and variability of relevant quantities over a period ranging from months to thousands or millions of years. The classical period is 30 years, as defined by the World Meteorological Organization (WMO). These quantities are usually surface variables such as temperature, precipitation, and wind. The climate in the broader sense is the state, including a statistical description, of the climate system (http://www.wmo.int/pages/prog/wcp/ccl/faq/faq_doc_en.html). Climate and weather are notable and influential factors in tourists' consumer behavior (Amelung, Nicholls, \& Viner, 2007; Hamilton \& Tol, 2007; Hamilton, Maddison, \& Tol, 2005; Kulendran \& Dwyer, 2010; Scott, McBoyle, \& Schwartzentruber, 2004). The effects of the interaction between climate/weather and tourism are substantial and require close scrutiny in so far as climate and weather may strongly contribute to the determination of the tourist's destination choice. Small island destinations, for example, are cognizant of the importance of weather and climate. In fact, the Caribbean and the Mediterranean are the two largest global geographical densities propagating climate and weather as crucial attributes of their tourism product (i.e., Sun, Sand, Sea (SSS)). In addition, the combination of favorable weather and SSS product results in image building. For example, Barbados uses 'good weather' as a selling point with a money-back guarantee in the event that the weather fails (Scott \& Lemieux, 2009). 
There is considerable research with regards to the impact of weather and climate on tourism and the environmental resources that are critical attractions for tourism: for example, snow conditions, wildlife productivity, and biodiversity, as well as quality water and its levels (UNWTO \& UNEP, 2008). Past researchers (Belén Gómez Martín, 2005; Kulendran \& Dwyer, 2010; Scott et al., 2004) reveal that climate attracts visitors who expect favorable weather conditions at the destination. However, climate may also encourage people to stay in their own country rather than travel abroad (Hamilton \& Tol, 2007). Hence, climate acts as both a pull and a push factor that affects the motivations of tourists in their decision first to travel and in their destination selection (Amelung et al., 2007; Hamilton et al., 2005).

Climate and weather have, however, not been integrated into the mainstream tourism demand literature. This omission is surprising because seasonality triggered by climatic conditions has been recognized in the literature as a major challenge for tourism destinations; and, seasonality is closely associated with climate and weather. Seasonality is a concept that is well studied and documented in the literature. It is defined here as a pattern that repeats itself over fixed intervals of time (Makridakis, Wheelwright, \& McGee, 1983) and is revealed in recurring variations in natural phenomena, such as climate (Butler, 2001). Typical seasonal variables include cycles or patterns of differences in temperature, rainfall, snowfall, sunlight, and daylight. Such variables influence a destination's seasonal demand where swings in demand may produce situations of overcapacity, reduced utilization of infrastructure, decrease in the workforce, and absence of investments during low seasons (Pegg, Patterson, \& Vila Gariddo, 2012), causing reduced profitability and productivity (Karamustafa \& Ulama, 2010). On the other hand, peak seasons may be characterized by overuse of public utilities (e.g., water supply, waste management, and road use), causing dissatisfaction for residents and tourists alike, while the environment may suffer irreversible damage because of 
tourism pressures (Cuccia \& Rizzo, 2011). Thus, the relationship between climate/weather and seasonal demand patterns becomes clear.

Most studies on the determinants of tourism demand have concentrated on economic factors (e.g., income and price) (Goh, 2012) while remaining particularly silent on the potential impact of climate on the choice of destinations (Kulendran \& Dwyer, 2010). For example, Song, Witt, and Li (2009) and Song, Dwyer, Li, and Cao (2012), in reviewing the determinants of tourism demand models, do not consider climate as a relevant factor. Shareef, Suhejla, and MacAleer (2008) examined 53 papers published about tourism demand in small islands, which omitted climate as a determinant of tourism demand. On the other hand, studies by Kulendran \& Dwyer (2010), Yu, Schwartz, and Walsh (2010), Buckley \& Foushee (2012), Hadwen, Arthington, Boon, Taylor, and Fellows (2011), and Goh (2012) have shown that climate exerts an influence on the seasonal pattern of tourism. Only a handful of studies, however, have considered climate and weather thus far as important factors affecting tourism demand (Lohmann \& Kaim, 1999; Scott \& Lemieux, 2009).

Understanding seasonal patterns that impact tourism consumption and production is crucial for tourism enterprises and regions (Chan \& Lim, 2011; Cuccia \& Rizzo, 2011; Dritsakis, 2008; Hadwen et al., 2011; Yu, Schwartz, \& Walsh, 2009). A large number of tourism demand studies are based on annual data (Bicak, Altinay, \& Jenkins,2005; Croes, 2010; Croes \& Vanegas, 2005; Lim, 1997; Petrevska, 2012; Song \& Li, 2008; Sookram, 2011; Vanegas \& Croes, 2000). It is not possible to study seasonal influences when only considering annual time series data. Rather, more frequent observed time series data than annual time series are required for the understanding of the complete effects of seasonality that would include climate and weather (Dritsakis, 2008). 
Studies that have resonated with the interaction of climate and tourism demand share some common core assumptions. First, the climate is articulated as a pull factor but does not take into account the possible push of climate as a factor of seasonality in tourism. Second, seasonal climatic patterns are assumed to be similar in overall effect (i.e., seasonal, cyclical, trend, and irregular components), to the logic of income and price that exhibit trend effects rather than seasonality effects. Yu et al. (2010) make the case, however, to define the focus of their investigation on seasonal patterns of climate variables because weather impacts are often contained in the seasonal components. And, third, climate seasonality studies have been based mainly on investigating tourism demand in large destinations (e.g., Australia and the USA).

Given the dearth of studies that investigate how climate influences seasonal patterns of tourism demand in small island destinations, there is a case to better understand the drivers of tourism demand in small island economies. This study investigates whether seasonal patterns of pull and push climate elements (including rainfall, wind, temperature, and cloud coverage) affect the seasonal deviations of tourism demand for a small island destination. The study accesses Aruba as the case of interest. According to Yin (2009), individual case studies may contribute to scientific generalizations through the replication effect, where the mode of generalization is analytic (i.e., analytic generalization). The goal then is to expand and generalize theories, and not to enumerate frequencies (statistical generalizations). According to Eisenhardt \& Graebner (2007), building theory from case studies is a research strategy that requires at least one case to create theoretical constructs, propositions, and/or midrange theory from case-based empirical evidence.

The methodology involves data decomposition using the Census X-12 technique with subsequent transformation of time series data into panel data, followed by panel unit root testing, panel regression, and Euclidean distance calculation. The analysis strategy employed here is novel when considering 
studies on the effect of climate on short-term tourism demand. The novelty is in the solving of the issue of seasonal unit roots that may cause permanent changes in seasonal patterns.

The investigation makes three key contributions to the tourism literature. First, it contributes to the further understanding of the specific role of seasonal patterns of climate variables on the seasonality of tourism demand. Second, this investigation simultaneously analyzes the impact of both pull and push climate factors on tourism demand seasonality, which departs from mainstream time series-/panel-based studies on this relationship. Third, the study postulates a novel research strategy calibrating the effects of both pull and push seasonal factors on tourism demand seasonality.

The rest of this paper is organized as follows. Section 2.2 presents an overview of the literature covering the empirical relationship between climate and tourism seasonal movements. Section 2.3 discusses climate and tourism conditions in Aruba, while Section 2.4 reviews the data and the applied methodology. Section 2.5 presents the empirical results. Finally, Section 2.6 concludes and indicates some policy implications and lines for future research.

\subsection{Tourism and climate seasonality in the literature}

The literature on the impact of climate on tourism demand generally adopts either a micro or a macro approach. Pivotal for the micro-approach is the measurement of people's responses to a set of questions, where they report their subjective state and values (Stiglitz, Sen, \& Fitoussi, 2009). People's perceptions of climate conditions are likely to play a central role in their decision-making process as tourists (UNWTO \& UNEP, 2008). For example, Behringer, Buerki, and Fuhrer (2000) interviewed 1000 skiers and snowboarders in five resorts in Central Switzerland, and their findings suggest climate change leading to less snow would have serious implications as a result of lower demand. Moreno Sánchez (2010) found, in a survey of tourists waiting for departure flights to European coastal destinations, at Dutch and Belgian 
airports, that climate was at the top of their list of destination attributes. More specifically, the absence of rain, a comfortable temperature, and a good number of hours of sunlight scored the highest in terms of their importance to beach tourism. Coombes \& Jones (2010) examined the behavior of visitors participating in different activities (e.g., dog walking, recreational walking, relaxing and sunbathing) through bi-weekly surveys undertaken at two beaches on the East Coast of the U.K. They found that warmer weather condition had a positive effect on visitor numbers.

A second strand in the tourism literature has explored the impact of climate on tourism from a macro-perspective, whereby variables representing climate are assessed against those of tourism demand. Within this literature, there is a first group of researchers who gauge the future impact of climate on tourism through simulation models (e.g., Berrittella, Bigano, Rosen, \& Tol, 2006; Hamilton et al., 2005; Hamilton \& Tol, 2007; Scott et al., 2004; Soboll \& Dingeldey, 2012). These forward-looking studies incorporated multiple destinations as units of analysis, making scenarios for up to the year 2100. All these investigations found that climate change will have an impact on future tourism demand.

Another group of researchers within this strand analyzed the relationship between climate change and tourism based on past conditions. For example, Yu et al. (2010) investigated the relationship between climate and tourism in terms of seasonality for the Denali National Park in Alaska and the Everglades in Florida. Their data consisted of hourly weather observations and monthly statistics, both ranging from 1979 to 2006. They further integrated the multiple weather elements (e.g., rain, lightning, hail, and snow) in a climate index in order to generate unidimensional weather data. The applied methodology consisted of three stages. First, they decomposed the data into a stochastic trend and a seasonal component, given their specific interest in the seasonal patterns of both statistics. Next, they standardized the seasonal 
patterns to compare their shapes using a Euclidean distance measure, and, last, the authors applied univariate regression analysis to estimate the relationship between climate and seasonal tourism demand. The results showed that climate plays a dominant role in shaping the seasonal patterns of tourism demand in both Denali and the Everglades.

Kulendran \& Dwyer (2010) measured the influence of changes in temperature, humidity, and sunshine on tourist arrivals from the USA, United Kindom (UK), Japan, and New Zealand for the case of Australia. They collected data from the third quarter of 1975 to the third quarter of 2009, subsequently extracting their seasonal patterns using the Basic Structural Model approach. The authors applied the Euclidean distance method to investigate the link between the (standardized) variations of climate indicators and seasonal tourism demand. Next, they used the autoregressive conditional heteroskedasticity (ARCH) modeling approach to estimate the direct impact of temperature, humidity, and sunshine on the seasonal pattern of tourism demand. The results showed links between the climate variability and seasonal pattern of tourism demand from all four origin markets, although the results tended to vary by season and country of origin. The results from the ARCH modeling approach showed that the impact of the climate variables on the seasonal patterns of tourism demand varied by country of origin.

Buckley \& Foushee (2012) showed that peak attendance in US national parks that have been experiencing climate change had shifted four days earlier since 1979. They gathered monthly visitors and temperature data between 1979 and 2008. The authors applied a direct Fourier transformation method to determine the seasonal patterns, and their analysis focused on the shifts in the seasonal distribution of visits rather than the changes in the shape of the distribution. Moreover, their results showed that humans tend to shift their behavior in response to climate change. 
Hadwen et al. (2011) assessed the relative importance of natural versus institutional factors in driving tourism demand seasonality. For this purpose, the authors collected visitor statistics from 23 protected areas, spread across Australia's six climate zones. The statistics on visitors varied per region, and included data on, for example, the number of campers per month, the number of vehicles at one or more campsites, and the number of visits. The data also varied in terms of frequency (monthly or daily) and period (1995-2000; 20002006; 2001-2002; 2004-2006). Climate data included temperatures and rainfall on a monthly basis. The timing of holiday periods was used as an institutional factor that explained the seasonality in visitation. The monthly visitation statistics were subsequently transformed into monthly percentage changes and regressed against the climate and holiday variables. The results showed climate was the principal force driving seasonal patterns of visitation in most of Australia's six climate zones.

The results of the previously presented investigations show several distinct features in the analysis of the relationship between climate and tourism demand. First, the studies were all characterized by a high level of heterogeneity in terms of methodological approach, a feature also signaled by Bigano, Goria, Hamilton, and Tol (2005). The heterogeneity makes these studies not readily comparable. Second, only a few studies have assessed the impact of climate on the seasonal patterns of tourism demand, which, given the importance of seasonality for tourism demand, is a weakness in the literature. Third, whether it is a micro- or a macro-perspective, past conditions, or simulations, climate does seem to impact the demand of tourists.

\subsection{Climate conditions and tourism in Aruba}

\subsubsection{Climate conditions}

The island of Aruba is located in the tropics and has a tropical steppe, hot semiarid climate. The wind over Aruba blows for more than $95 \%$ of the time from the northeast and the southeast direction, at an average speed of $7.3 \mathrm{~m} / \mathrm{s}$ at 
$10 \mathrm{~m}$ distance (1981-2010). The minimum wind speed is observed in October and November, and the strongest winds are recorded in May-July (Departamento Meteorologico Aruba, 2012). The average temperature in Aruba is $28.1{ }^{\circ} \mathrm{C}$, varying from $20.6{ }^{\circ} \mathrm{C}$ to $36.5^{\circ} \mathrm{C}$. The coldest months are January and February and the warmest months are August and September. The average yearly rainfall in Aruba for the period (1981-2010) was $471.7 \mathrm{~mm}$. The wettest months are from October through December, and the driest months are March through May. The potential for thunderstorms on Aruba is relatively low, as compared with the rest of the Tropics. There were, on average only 17.9 days per year when thunderstorms passed over the observation site in Aruba (19812010). The average relative humidity for that period was $77.4 \%$, while the average cloud coverage on the island was $47.3 \%$, with the lowest average in January and the highest in May. On a daily basis, the average cloudiness of the sky was highest in the morning hours and lowest in the late evening.

\subsubsection{Tourism}

Aruba has more than 50 years of experience with tourism. The island increased its focus on further developing tourism activities, following the closure of its main economic pillar, the Lago oil refinery, in 1985 (Ridderstaat, 2007). The number of hotel rooms more than tripled, from 2524 in 1986 to 7975 in 2011. The efforts paid off: the number of stay-over visitors grew from 181,211 in 1986 to 871,316 in 2011 . The stimulus also included cruise tourism, where the number of cruise passengers grew from 73,338 in 1986 to 599,893 in 2011. Tourism receipts grew from US\$ 157.2 million in 1986 to US\$1,340.8 million in 2011. The USA is by far the largest market for Aruba, accounting for, on average, 63.3\% of all stay-over visitors between 1986 and 2011. Tourists mainly come from the North-Eastern part of the States. The Venezuelan market is the second-largest market for Aruba (average 12.0\% between 1986 and 2011). Together, these two countries accounted on average for about $75.3 \%$ of all stay-over visitors to Aruba between 1986 and 2011. 


\subsection{Data and Methods}

The basis for this study is the conceptual scheme depicted in Figure 2.1, where pull and push factors of weather elements are set against those of tourism demand. According to Matzarakis (2006), the most relevant meteorological parameters include air temperature, air humidity, wind speed, wind direction, cloud coverage, sunshine duration, or radiation fluxes, rain and precipitation, snow coverage, and water temperature. For this research, we use four weather fundamentals (cloud coverage, rainfall, temperature, and wind speed) as pull factors (i.e., the weather conditions in Aruba that attract visitors), and three weather elements (rainfall, temperature, and wind speed) as push factors (i.e., weather conditions in both the USA and Venezuela that cause residents to travel to destinations like Aruba). Data on cloud coverage in the USA and Venezuela were not available for the complete period of analysis, which is why they were not included in the study. The variables used in this investigation are shown in Table 2.1.

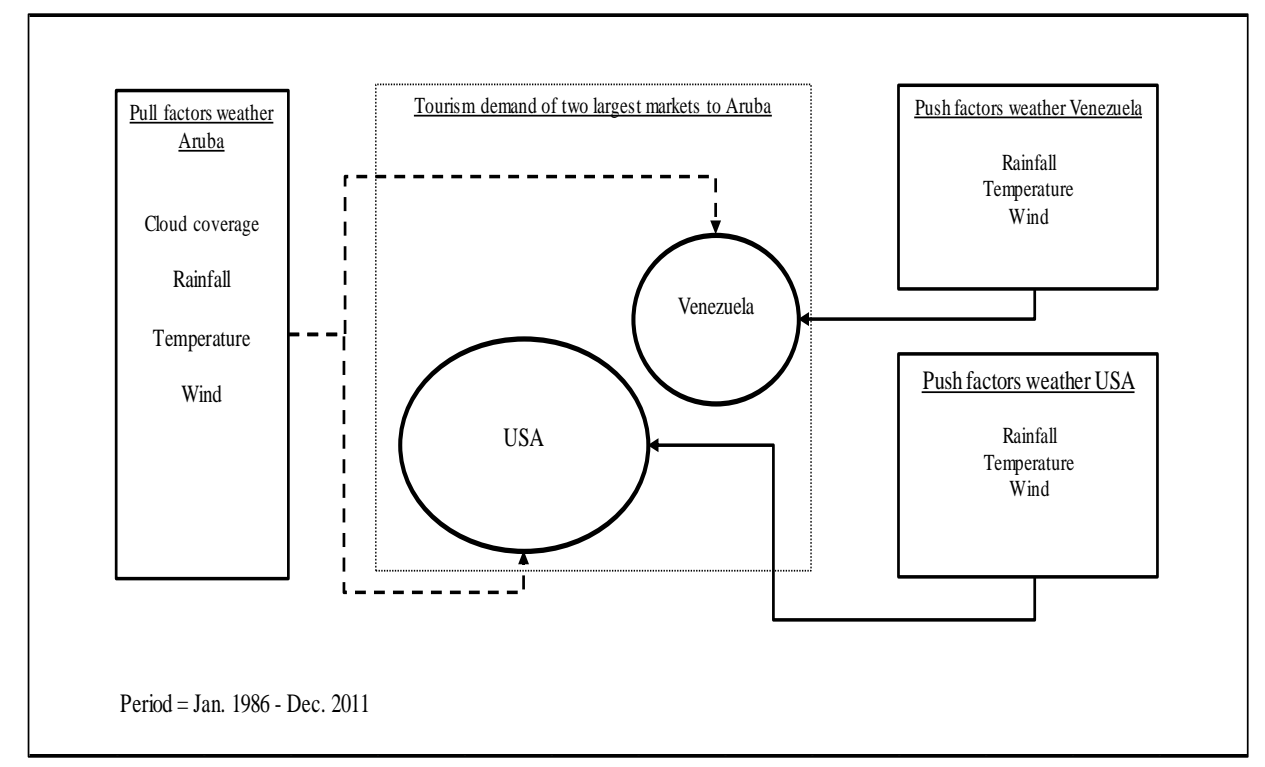

Figure 2.1: Conceptual framework of the relation between the seasonal patterns of (pull/push) weather and tourism demand for the largest market of Aruba's tourism. 
Climate data for Aruba are from the Meteorological Department of Aruba. The related data for the USA are from the North-Eastern part of that country, given that most US visitors to Aruba are from that region. The climate data for this country come from several sources, including the Global Precipitation Climatology Centre and the European Centre for Medium-Range Weather Forecasts. Climate data for Venezuela (Caracas) are from the same sources as those of the USA.

Tourism demand is proxied by the number of visitors from (particularly the North-Eastern part of) the USA and Venezuela, and the data were collected from the Central Bank of Aruba. All series have been transformed into logarithms in order to stabilize their variance (Farooque, 2003). The descriptive statistics of the transformed data in Table 2.1 show limited volatility, which facilitates further logical analysis of the selected variables.

As a first step, the study applied the Census X-12 decomposition procedure to dissect the series into a seasonally-adjusted series (SA) (which consists of a trend-cycle (TC) and irregular elements (IR)) and a seasonal factor (SF). The Census X-12 decomposition procedure is a widely-used application based on software developed and maintained by the US Bureau of Census. Basically, the method applies a series of sophisticated moving averages to estimate the SF, with additional calculations of the TC and IR elements. The International Monetary Fund (2000) describes the TC as a combination of the long-term trend and the (business) cycle movements in the data. Furthermore, the IR captures effects that are unpredictable, including outliers and other irregular effects such as unseasonable weather, natural disasters, strikes, etc. 
Table 2.1: Variables used in the analysis.

\begin{tabular}{|c|c|c|c|c|c|c|c|}
\hline Variable & Description & Mean & Median & Maximum & Minimum & $\begin{array}{l}\text { Standard } \\
\text { deviation }\end{array}$ & $\begin{array}{r}\text { Coefficient } \\
\text { of } \\
\text { variation } \\
\text { (in \%) }\end{array}$ \\
\hline LAUA_CLOUD & Cloud coverage in Aruba 1] & 3.8559 & 3.8918 & 4.3399 & 3.0007 & 0.2134 & 5.5 \\
\hline LAUA_RAIN & Rainfall in Aruba 1] & 4.8925 & 4.7858 & 6.0215 & 4.6052 & 0.3008 & 6.1 \\
\hline LAUA_TEMP & Temperature in Aruba 1] & 3.3368 & 3.3393 & 3.4177 & 3.2465 & 0.0371 & 1.1 \\
\hline \multicolumn{8}{|l|}{ Push factors } \\
\hline \multicolumn{8}{|l|}{ United States } \\
\hline LUSA_RAIN & Rainfall in the USA 2] & 4.3773 & 4.4035 & 5.3232 & 3.1088 & 0.3526 & 8.1 \\
\hline LUSA_TEMP & Temperature in the USA 3] & 4.6909 & 4.6944 & 4.8065 & 4.5330 & 0.0779 & 1.7 \\
\hline LUSA_WIND & Wind in the USA 4] & 1.5948 & 1.6192 & 1.9184 & 1.1132 & 0.1742 & 10.9 \\
\hline \multicolumn{8}{|l|}{ Venezuela } \\
\hline LVEN_WIND & Wind in Venezuela 4] & 1.6652 & 1.6890 & 1.9334 & 1.2876 & 0.1384 & 8.3 \\
\hline \multicolumn{8}{|l|}{ Tourism demand } \\
\hline LUSA_TOUR & Touris m demand from the USA 5] & 10.2998 & 10.3889 & 10.9381 & 8.9149 & 0.4221 & 4.1 \\
\hline LVEN_TOUR & Tourism demand from Venezuela 5] & 8.5275 & 8.6201 & 9.9317 & 6.1903 & 0.7025 & 8.2 \\
\hline
\end{tabular}

Sources of data:

1] Meteorological Department Aruba.

2] Global Precipitation Climatology Centre operated by Deutscher Wetterdienst.

3] National Centers for Environmental Prediction-National Center for Atmospheric Research (NCEP-NCAR) reanalys is (NCEP1) data.

4] The European Centre for Medium-Range Weather Forecasts (ECMWF) Re-Analysis (ERA-Interim).

5] Central Bank of Aruba. 
Prior to applying the Census X-12 technique, the data were analyzed according to the type of model (additive or multiplicative) to which they belong. For this purpose, the study applied a model taken from den Butter \& Fase (1988):

$\left|Y_{t}-Y_{t}\right|=\alpha+\beta Y T_{t}+\varepsilon_{t}$

where:

$\mathrm{Y} \quad=$ the original value of the time series;

$\mathrm{YT}=$ the centralized moving average of $\mathrm{Y}$ over a year;

$\alpha, \beta=$ coefficients;

$\mathrm{t} \quad=$ time;

$\varepsilon \quad=$ residual.

If $\mathrm{Y}$ and $\mathrm{YT}$ are uncorrelated, which means that the coefficient $\beta$ is not significantly different from zero, the model type is then considered additive. If $\beta$ is significantly different from zero, the model is multiplicative. The question here basically boils down to whether movements away from the moving trend (the absolute difference between $\mathrm{Y}$ and $\mathrm{YT}$, or $|\mathrm{Y}-\mathrm{YT}|)$, be it $\mathrm{C}$, SF or IR, are related to YT or not. If they are (i.e., $\beta$ is significantly different from zero), then the T, C, SF and IR elements are related to each other in a multiplicative way. Otherwise (i.e., $\beta$ is not significantly different from zero), they have an additive relation with each other. Testing for the relative importance of seasonal factors in the overall short-term volatility of the applied variables is done using the following regression:

$\Delta$ Series $_{\mathrm{t}}=\alpha_{1} \Delta$ Series $_{\mathrm{El}, \mathrm{t}}+\varepsilon_{1, \mathrm{t}}$,

where:
$\Delta \quad=$ first difference;
El = series' element (TC, SF or IR);
$\mathrm{t}=$ time;
$\varepsilon \quad=$ residual. 
The aim here is to determine the coefficient of determination (adjusted R2) in order to assess the contribution of each of these three elements to the variability of the overall series. Given that the differencing occurs over a short-time range (i.e., month versus the next month), it is expected that the effects of the monthly differences would be likely dominated by a combination of both SF and IR elements.

Working with seasonal factors implies the possibility of the presence of seasonal unit roots, whereby seasonal patterns may change permanently due to shocks (Hylleberg, Engle, Granger, \& Yoo, 1990). The existing seasonal tests (e.g., Beaulieu \& Miron, 1993; Franses, 1990; Hylleberg et al., 1990) are more complex than the simple unit root tests because seasonal time series tend to have different roots (e.g., quarterly and semi-annual) than the conventional long-run frequency (Song et al., 2009). Furthermore, according to Rodrigues and Franses (2005), the power of seasonal unit roots deteriorates the more unit roots one has to examine. To circumvent the problem of seasonal unit root testing, the structure of the data was amended from time-series-based to paneloriented:

$\mathrm{V}_{\mathrm{t}} \rightarrow \mathrm{V}_{\mathrm{i}, \mathrm{t}}$

where:

$$
\begin{aligned}
\mathrm{V} & =\text { variable; } \\
\mathrm{t} & =\text { time; } \\
\mathrm{i} & =\text { group or unit. }
\end{aligned}
$$

Each variable now contains 12 units (January-December), and each unit has 26 years of data (1986-2011). Subsequently, we proceeded to test for stationarity in panel data by applying a simpler unit root test (than the seasonal unit root test) provided by Im, Pesaran, and Shin (2003). 
The model behind this test is as follows (Asteriou, 2006):

$$
\Delta \mathrm{Y}_{\mathrm{i}, \mathrm{t}}=\mathrm{a}_{\mathrm{i}}+\rho_{\mathrm{i}} \mathrm{Y}_{\mathrm{i}, \mathrm{t}-1}+\sum_{\mathrm{k}=1}^{\mathrm{n}} \emptyset_{\mathrm{k}} \Delta \mathrm{Y}_{\mathrm{i}, \mathrm{t}-\mathrm{k}}+\delta_{\mathrm{i}} \mathrm{t}+\theta_{\mathrm{t}}+\mathrm{u}_{\mathrm{i}, \mathrm{t}}
$$

where:

$$
\begin{array}{ll}
\mathrm{Y} & \text { = variable to be tested; } \\
\mathrm{a} & =\text { intercept of unit element of panel; } \\
\mathrm{i} & =\text { unit element of panel; } \\
\mathrm{t} & =\text { time element of panel; } \\
\rho & =\text { coefficient to be tested for unit root; } \\
\theta & =\text { intercept of time element of panel; } \\
\mathrm{u} & =\text { residual. }
\end{array}
$$

The null hypothesis of this test is that all units are non-stationary, versus the alternative hypothesis that a fraction of the series in the panel is assumed to be stationary (Asteriou, 2006). The outcome of the unit root test determines whether data differencing is needed, and the eventual order of differencing. With the data requirements known, the study can then proceed to analyze whether the climate seasons are essential in determining short-term tourism demand. For this purpose, we tested three types of panel models, i.e. (1) a pooled OLS regression model, (2) a fixed-effects model (FEM), and (3) a random-effects model (REM). The following equations and methodological analyses were based on Gujarati (2012). 
The pooled OLS model, in this case, consists of the following equations:

$$
\begin{aligned}
\text { TDCO }_{i, t}=\alpha_{i, t}+ & \alpha_{2} \text { CAUA }_{i, t}+\alpha_{3} \text { RAUA }_{i, t}+\alpha_{4} \text { TAUA }_{i, t} \\
& +\alpha_{5} \text { WAUA }_{i, t}+\alpha_{6} \mathrm{RCO}_{i, t}+\alpha_{6} \text { TCO }_{i, t} \\
& +\alpha_{6} \mathrm{WCO}_{i, t}+u_{i, t}
\end{aligned}
$$

$\mathrm{i}=1 \ldots 12 ; \mathrm{t}=1986 \ldots 2011$,

where:

TDCO = tourism demand to Aruba from country of origin (USA or

Venezuela);

$\alpha$ 's $\quad=$ coefficients;

CAUA = cloud coverage in Aruba;

RAUA = rainfall in Aruba;

TAUA = temperature in Aruba;

WAUA = wind in Aruba;

$\mathrm{RCO}=$ rainfall in country of origin (USA or Venezuela);

TCO = temperature in country of origin (USA or Venezuela);

WCO = wind in country of origin (USA or Venezuela);

$\mathrm{u} \quad$ = residual. 
The FEM is indicated as follows:

$$
\begin{aligned}
& \left(\mathrm{TDCO}_{\mathrm{i}, \mathrm{t}}-\overline{\mathrm{TDCO}}_{\mathrm{i}}\right) \\
& =\alpha_{2}\left(\mathrm{CAUA}_{\mathrm{i}, \mathrm{t}}-\overline{\mathrm{CAUA}}_{\mathrm{i}}\right) \\
& +\alpha_{3}\left(\mathrm{RAUA}_{\mathrm{i}, \mathrm{t}}-\overline{\mathrm{RAUA}}_{\mathrm{i}}\right) \\
& +\alpha_{4}\left(\mathrm{TAUA}_{\mathrm{i}, \mathrm{t}}-\overline{\mathrm{TAUA}}_{\mathrm{i}}\right) \\
& +\alpha_{5}\left(\mathrm{WAUA}_{\mathrm{i}, \mathrm{t}}-\overline{\mathrm{WAUA}}_{\mathrm{i}}\right) \\
& +\alpha_{6}\left(\mathrm{RCO}_{\mathrm{i}, \mathrm{t}}-\overline{\mathrm{RCO}}_{\mathrm{i}}\right)+\alpha_{6}\left(\mathrm{TCO}_{\mathrm{i}, \mathrm{t}}-\overline{\mathrm{TCO}}_{\mathrm{i}}\right) \\
& +\alpha_{6}\left(\mathrm{WCO}_{\mathrm{i}, \mathrm{t}}-\overline{\mathrm{WCO}}_{\mathrm{i}}\right)+\mathrm{u}_{\mathrm{i}, \mathrm{t}} .
\end{aligned}
$$

To determine whether the FEM is superior to the pooled OLS model, we calculated a restricted F-test, which compares the coefficients of determination of both pooled OLS and FEM (see Gujarati, 2012).

The REM model is expressed as follows:

$$
\begin{aligned}
\text { TDCO }_{i, t}=\alpha_{i, t}+ & \alpha_{2} \text { CAUA }_{i, t}+\alpha_{3} \text { RAUA }_{i, t}+\alpha_{4} \text { TAUA }_{i, t} \\
& +\alpha_{5} \text { WAUA }_{i, t}+\alpha_{6} \text { RCO }_{i, t}+\alpha_{6} \text { TCO }_{i, t} \\
& +\alpha_{6} \text { WCO }_{i, t}+w_{i, t}
\end{aligned}
$$

where:

$$
\mathrm{W}_{\mathrm{i}, \mathrm{t}}=\varepsilon_{\mathrm{i}}+\mathrm{u}_{\mathrm{i}, \mathrm{t}}
$$


Basically, the error term $\mathrm{w}_{\mathrm{i}, \mathrm{t}}$ is composed of an individual-specific error $\left(\varepsilon_{\mathrm{i}}\right.$, with mean of zero and variance of $\sigma_{\varepsilon}^{2}$ ) and a combined time-series and crosssection error component. Furthermore, the REM assumes that the intercept of any cross-section unit is not fixed, but a random variable with a mean value of $\alpha_{1}$, and can, thus, be expressed as:

$\alpha_{1, \mathrm{i}} \quad=\alpha_{1}+\varepsilon_{\mathrm{i}}$.

To test for the adequacy of the REM against the FEM, we apply what is called the Hausman test, where the null hypothesis is that both the FEM and the REM do not differ significantly. The test involves the comparison of a calculated $\chi^{2}$ against a critical $\chi^{2}$. If the calculated $\chi^{2}$ is larger than the critical $\chi^{2}$, we can then conclude that the REM is not the appropriate model and that the FEM is to be preferred over the REM.

As a further step, we added a dummy variable to the equations, capturing the effect of vacation and holiday periods on tourism demand seasonality $(1=$ holiday or vacation period; $0=$ no holiday or vacation period). In the case of the USA, the selected holiday months were March, April, May, June, July, August, November, and December. For Venezuela, the months of February, March, April, June, July, August, September and December were selected. The selected months in both cases were based on national school vacation and official holidays. The vacation and holiday periods in the USA and Venezuela vary somewhat, but both countries have several holiday and vacation months in common (i.e., March, April, June, July, August, December). 
Lastly, based on the results of the model, which incorporates the vacation and holiday dummy, we calculated the monthly differences between the statistically significant seasonal factor of climate and the seasonal factors of tourism demand. The latter provides an indication of the strength of association during several periods of the year. For this purpose, we used the Euclidean distance measure formula, based on Kulendran and Dwyer (2010):

$\mathrm{EDM}_{m}=\sqrt{\frac{1}{\mathrm{n}} \sum_{\mathrm{i}=1}^{\mathrm{n}}\left(\text { climate series }_{m}-{\left.\text { tourism demand } \operatorname{series}_{m}\right)^{2}}\right.}$

where:

$\mathrm{EDM}=$ Euclidean distance measure;

$\mathrm{n} \quad=$ number of values;

$\mathrm{m} \quad=$ month.

The smaller the EDM, the stronger the seasonal association between the climate factor and the tourism demand factor.

\subsection{Empirical results}

All estimates were obtained from Eviews version 7 and Excel 2010. The regression results show that those variables with the additive form dominated slightly over those with the multiplicative form, implying that, in most cases, the elements of the cycle, seasonal, and irregular factors were unrelated to the moving trend (Table 2.2). 
Table 2.2: Model type selection based on significance of coefficient of the independent variable.

\begin{tabular}{|c|c|c|}
\hline \multicolumn{3}{|l|}{ Variable type } \\
\hline & \multicolumn{2}{|l|}{ Model type selection } \\
\hline & Regression result of $\beta$ & Model type \\
\hline \multicolumn{3}{|l|}{ Pull factors } \\
\hline LAUA_CLOUD & $-0.2159 * * *$ & multiplicative \\
\hline LAUA_RAIN & $-1.0768 * * *$ & multiplicative \\
\hline LAUA_TEMP & 0.0627 & additive \\
\hline LAUA_WIND & $-0.2546 * * *$ & multiplicative \\
\hline \multicolumn{3}{|l|}{ Push factors } \\
\hline \multicolumn{3}{|l|}{ United States } \\
\hline LUSA_RAIN & -0.0464 & additive \\
\hline LUSA_TEMP & -0.5034 & additive \\
\hline LUSA_WIND & -0.0072 & additive \\
\hline \multicolumn{3}{|l|}{ Venezuela } \\
\hline LVEN_RAIN & -0.0023 & additive \\
\hline LVEN_TEMP & 0.0304 & additive \\
\hline LVEN_WIND & $-0.4898 *$ & multiplicative \\
\hline \multicolumn{3}{|l|}{ Venezuela } \\
\hline LVEN_RAIN & -0.0023 & multiplicative \\
\hline \multicolumn{3}{|l|}{ Tourism demand } \\
\hline LUSA_TOUR & $-0.0396 * * *$ & multiplicative \\
\hline LVEN_TOUR & 0.0413 & additive \\
\hline
\end{tabular}

Note: The symbols $* * *$ and * indicate significance at, respectively, $1 \%$ and $10 \%$.

The series was subsequently decomposed using the Census X-12 technique, taking into consideration their model form. The regression results from the analysis of short-term explanatory power indicate that both seasonal and irregular factors did indeed explain most of the short-range variability of the 
series, with the seasonal factors explaining more than $50 \%$ of the variability in temperature in Aruba; temperature and wind in both the USA and Venezuela; and tourism demand from both the USA and Venezuela (Table 2.3). These results suggest that the causation of the short-term volatility of the indicated variables is largely due to repeating factors over time. Given the important influence of seasonality in tourism demand of both countries of origin, and the nature of the irregular factors (i.e., they are unpredictable, with possible outliers and other irregular effects that are normally not expected to affect seasonality permanently), we omitted the effects of irregular factors from the rest of the analysis.

Table 2.3: Explanatory power of time-series elements.

\begin{tabular}{llll}
\hline Dependent variable type & $\begin{array}{l}\text { Adj. } \mathrm{R}^{2} \\
\text { trend-cycle }\end{array}$ & $\begin{array}{l}\text { Adj. } \mathrm{R}^{2} \text { seasonal } \\
\text { factor }\end{array}$ & $\begin{array}{l}\text { Adj. } \mathrm{R}^{2} \text { irregular } \\
\text { factor }\end{array}$ \\
\hline$\Delta$ LAUA_CLOUD & 0.0117 & 0.3527 & 0.5484 \\
$\Delta$ LAUA_RAIN & 0.0126 & 0.1814 & 0.7855 \\
$\Delta$ LAUA_TEMP & 0.0388 & 0.6989 & 0.2369 \\
$\Delta$ LAUA_WIND & 0.0091 & 0.3389 & 0.6257 \\
& & & 0.8098 \\
$\Delta$ LUSA_RAIN & 0.0043 & 0.1792 & 0.1419 \\
$\Delta$ LUSA_TEMP & 0.0012 & 0.8667 & 0.4529 \\
$\Delta$ LUSA_WIND & 0.0014 & 0.5348 & 0.6324 \\
$\Delta$ LVEN_RAIN & & & 0.3416 \\
$\Delta$ LVEN_TEMP & 0.0088 & 0.3688 & 0.2125 \\
$\Delta$ LVEN_WIND & 0.0532 & 0.5932 & 0.1957 \\
$\Delta$ LUSA_TOUR & 0.0014 & 0.8122 & 0.2821 \\
$\Delta$ LVEN_TOUR & 0.0274 & 0.8159 & \\
\hline & 0.083 & 0.6898 & \\
\hline
\end{tabular}

Note: $\Delta=$ first difference of variable. Adj. $\mathrm{R}^{2}=$ adjusted coefficient of determination. The higher the adj. $R^{2}$, the more explanatory power an element of the variable has. 
Charts 1.1 - 1.12 (Figure 2.2) provide an overview of the standardized seasonal factors of the variables. Standardization makes the seasonal factors comparable to each other, and practically eliminates the distinction whether the seasonal factors were derived from an additive or a multiplicative model. The charts show that the seasonal patterns are dynamic over time, with changing amplitudes (maximum and minimum points).

With the time series transformed to panel data, the next analysis involves assessing the data for stationarity, using the Im et al. (2003) unit root test. The results are included in Table 2.4 and show that most variables were either integrated of zero or first order. Only the variables representing rainfall in Aruba and wind in Venezuela showed clear signs of being I(1). All variables were subsequently transformed into the first difference for calculating the relationships between the seasonal factors of weather and those of tourism demand from both the USA and Venezuela. 


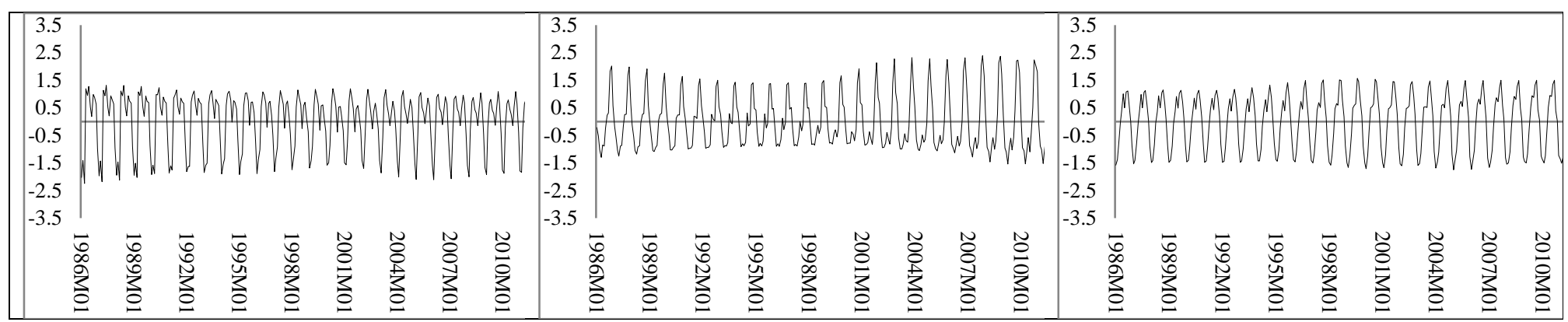

Chart 1.1: Standardized seasonal factors of cloud coverage in Aruba.

Chart 1.2: Standardized seasonal factors of rainfall in Aruba.
Chart 1.3: Standardized seasonal factors of temperature in Aruba.

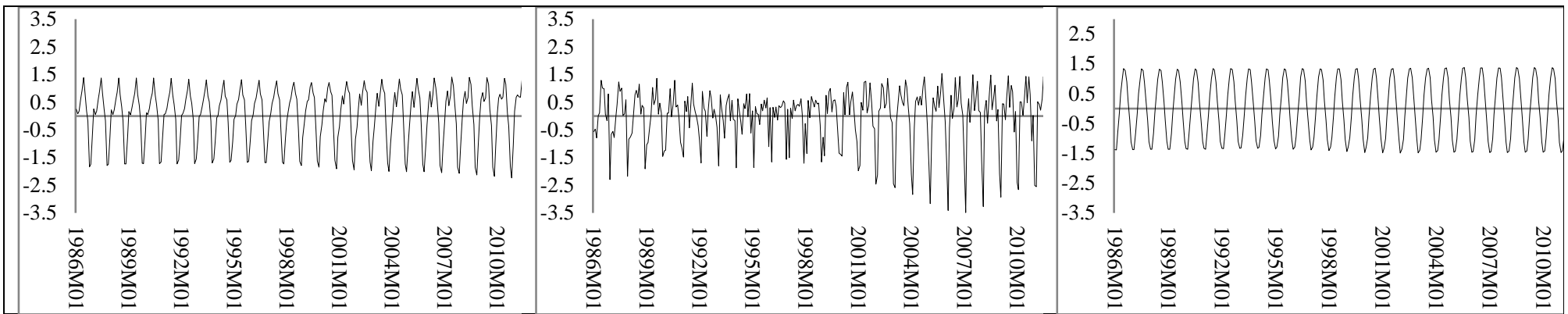

Chart 1.4: Standardized seasonal factors of wind in Aruba.

Chart 1.5: Standardized seasonal factors of rainfall in the USA.
Chart 1.6: Standardized seasonal factors of temperature in the USA.

Figure 2.2. Chart 1.1: Standardized seasonal factors of cloud coverage in Aruba. Chart 1.2: Standardized seasonal factors of rainfall in Aruba. Chart 1.3: Standardized seasonal factors of temperature in Aruba. Chart 1.4: Standardized seasonal factors of wind in Aruba. Chart 1.5: Standardized seasonal factors of rainfall in the USA. Chart 1.6: Standardized seasonal factors of temperature in the USA. 


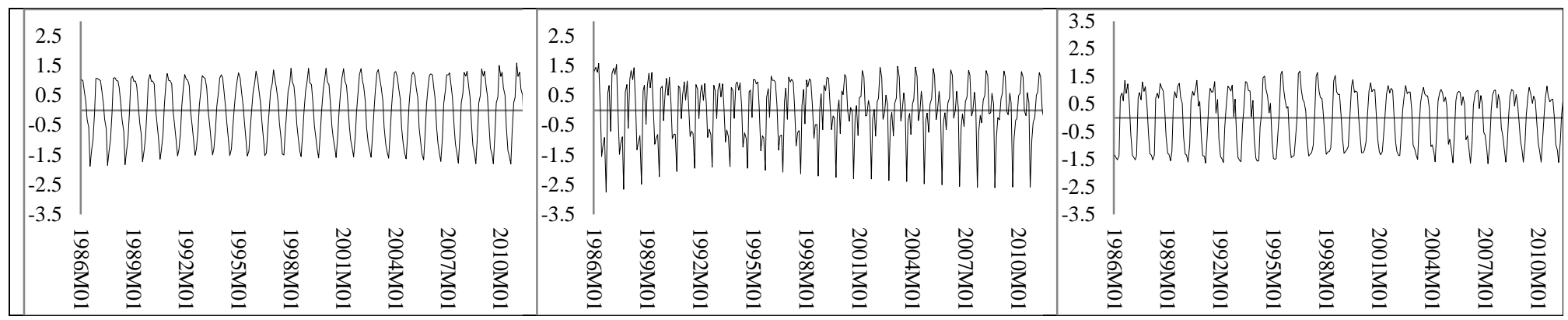

Chart 1.7: Standardized seasonal factors of wind in the USA.

Chart 1.8: Standardized seasonal factors of tourism demand from the USA.
Chart 1.9: Standardized seasonal factors of rainfall in Venezuela.

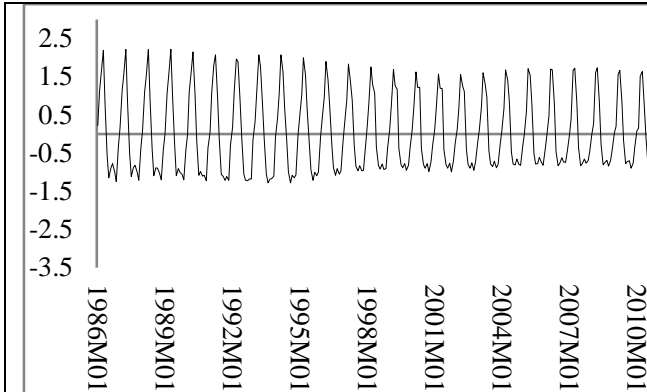

Chart 1.10: Standardized seasonal factors of temperature in Venezuela.

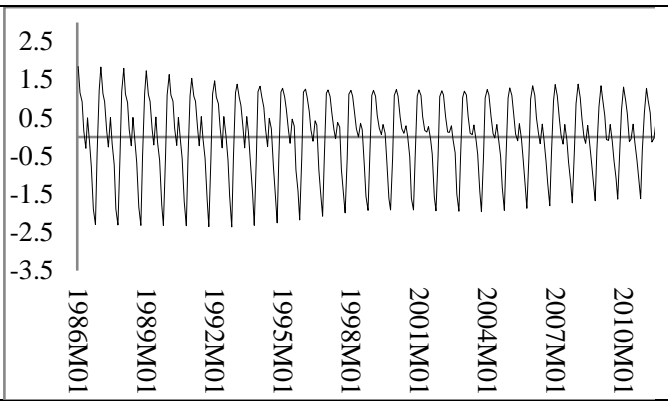

Chart 1.11: Standardized seasonal factors of wind in Venezuela.

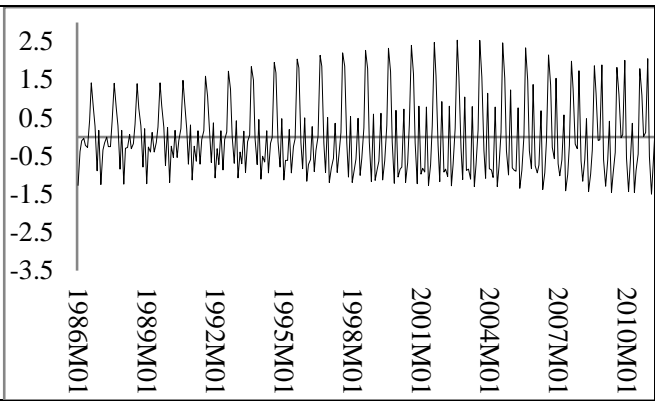

Chart 1.12: Standardized seasonal factors of tourism demand from Venezuela.

Figure 2.2 (continued). Chart 1.7: Standardized seasonal factors of wind in the USA. Chart 1.8: Standardized seasonal factors of tourism demand from the USA. Chart 1.9: Standardized seasonal factors of rainfall in Venezuela. Chart 1.10: Standardized seasonal factors of temperature in Venezuela. Chart 1.11: Standardized seasonal factors of wind in Venezuela. Chart 1.12: Standardized seasonal factors of tourism demand from Venezuela. 
Table 2.4: Panel unit root test results.

\begin{tabular}{|c|c|c|c|c|c|}
\hline \multirow[b]{2}{*}{ variable } & \multicolumn{2}{|c|}{$\bar{t}_{\text {-values (intercept only) }}$} & \multicolumn{2}{|c|}{$\bar{t}$-values (intercept and trend) } & \multirow{2}{*}{$\begin{array}{l}\text { Degree of } \\
\text { integration }\end{array}$} \\
\hline & Lag $=0$ & $\mathrm{Lag}=1$ & $\mathrm{Lag}=0$ & $\mathrm{Lag}=1$ & \\
\hline P_LAUA_CLOUD & $-2.0905 * * *$ & $-2.9245 * * *$ & $-3.8988 * * *$ & $-3.2984 * * *$ & $\mathrm{I}(0)$ or $\mathrm{I}(1)$ \\
\hline P_LAUA_RAIN & -1.5044 & $-2.6609 * * *$ & -2.0791 & $-3.0067 * * *$ & $\mathrm{I}(1)$ \\
\hline P_LAUA_TEMP & -1.6816 & $-3.2900 * * *$ & $-2.8722 * * *$ & $-3.6325 * * *$ & $\mathrm{I}(0)$ or $\mathrm{I}(1)$ \\
\hline P_LAUA_WIND & $-2.1708 * * *$ & $-3.0187 * * *$ & $-3.6821 * * *$ & $-3.4085 * * *$ & $\mathrm{I}(0)$ or $\mathrm{I}(1)$ \\
\hline P_LUSA_RAIN & -1.5164 & $-3.8855 * * *$ & $-4.1346 * * *$ & $-4.1138 * * *$ & $\mathrm{I}(0)$ or $\mathrm{I}(1)$ \\
\hline P_LUSA_TEMP & $-2.0527 * * *$ & $-2.4903 * * *$ & $-2.4615 *$ & $-2.8929 * * *$ & $\mathrm{I}(0)$ or I $(1)$ \\
\hline P_LUSA_WIND & -1.0875 & $-4.0201 * * *$ & $-3.6307 * * *$ & $-4.1427 * * *$ & $\mathrm{I}(0)$ or $\mathrm{I}(1)$ \\
\hline P_LVEN_RAIN & $-2.0342 * *$ & $-3.1155 * * *$ & $-3.3355 * * *$ & $-4.3447 * * *$ & $\mathrm{I}(0)$ or $\mathrm{I}(1)$ \\
\hline P_LVEN_TEMP & -1.5601 & $-3.5292 * * *$ & $-3.4304 * * *$ & $-4.0127 * * *$ & $\mathrm{I}(0)$ or $\mathrm{I}(1)$ \\
\hline P_LVEN_WIND & -1.2922 & $-3.1416 * * *$ & -2.3105 & $-3.7425 * * *$ & $\mathrm{I}(1)$ \\
\hline P_LUSA_TOUR & $-1.8584 *$ & $-4.5055 * * *$ & $-4.4369 * * *$ & $-4.7402 * * *$ & $\mathrm{I}(0)$ or $\mathrm{I}(1)$ \\
\hline P_LVEN_TOUR & $-1.9736 * *$ & $-3.9191 * * *$ & $-3.7415 * * *$ & $-4.1578 * * *$ & $\mathrm{I}(0)$ or $\mathrm{I}(1)$ \\
\hline Critical values & Intercept & & Intercept and $\mathrm{t}$ & end & \\
\hline $1 \%$ & -2.05 & & -2.68 & & \\
\hline $5 \%$ & -1.90 & & -2.53 & & \\
\hline $10 \%$ & -1.82 & & -2.45 & & \\
\hline
\end{tabular}

Note: Test is based on panel unit root test proposed by Im et al. (2003). ***,** and * indicate significance at, respectively, the $1 \%, 5 \%$ and $10 \%$ level. $\mathrm{H}_{0}=$ series is non-stationary. A series is considered stationary if $\bar{t}<\mathrm{t}_{\text {critical value. }}$

Table 2.5 provides the results of the tested equations. In the estimation models without the holiday dummy, the results of the restricted F-test show that, in both cases, the FEM is superior to the pooled OLS model to estimate the impact of seasonal factors of weather on the tourism demand variables (USA: $\mathrm{F}(11,292)=5.3361 \quad(\mathrm{p}=0.000)$; Venezuela: $\mathrm{F}(11,292)=5.6498(\mathrm{p}=0.000))$. The Hausman test in the case of the USA as the dependent variable was 10.1237 (d.f.=7 and $\mathrm{p}=0.1817$ ), indicating that the unit-specific effects were not correlated with any of the explanatory variables included in the model and that the REM was the appropriate model to use. In the case of Venezuela, the Hausman test was 13.5571 (d.f. $=7$ and $p=0.0596$ ), revealing that the unitspecific effects were correlated with the explanatory variables in the model, meaning that the FEM was the most suitable model to use in this case. 
Table 2.5: Panel regression results.

\begin{tabular}{|c|c|c|c|c|}
\hline & \multicolumn{2}{|c|}{ Model 1 (without holiday dummy) } & \multicolumn{2}{|c|}{ Model2 (with holiday dummy) } \\
\hline & Random effects model & Fixed effects model & Random effects model & Randomeffects model \\
\hline & USA & Venezuela & USA & Venezuela \\
\hline Intercept & -0.0002 & 0.0000 & $-0.0349 * * *$ & 0.0024 \\
\hline LAUA_CLOUD & -0.1179 & 0.0220 & $-0.1641 * * *$ & 0.0206 \\
\hline LAUA_RAIN & -0.0095 & $-0.1766 * * *$ & 0.0011 & $-0.1764 * * *$ \\
\hline LAUA_TEMP & 0.1224 & $-0.1865 *$ & 0.1753 & $-0.1909 * *$ \\
\hline LAUA_WIND & $0.3384 * * *$ & -0.1327 & $0.3427 * * *$ & -0.1240 \\
\hline LUSA_RAIN & $0.0518 * *$ & & $0.0523 * *$ & \\
\hline LUSA_TEMP & $-1.0572 * *$ & & $-0.9491 *$ & \\
\hline LUSA_WIND & $0.2754 * *$ & & $0.2907 * *$ & \\
\hline LVEN_RAIN & & $0.1047 * *$ & & $0.1056 * *$ \\
\hline LVEN_TEMP & & & & 0.0102 \\
\hline LVEN_WIND & & & & \\
\hline Dummy holiday USA & & & $0.0520 * * *$ & \\
\hline Dummy holiday Venezuela & & & & -0.0037 \\
\hline Adj. $R^{2}$ & 0.0511 & 0.0740 & 0.0854 & 0.0684 \\
\hline F-test & 3.3010 *** & $5.7776 * * *$ & $4.4914 * * *$ & $4.1385 * * *$ \\
\hline
\end{tabular}

Note: ${ }^{* * *},{ }^{* *}$ and $*$ indicate significance at, respectively, the $1 \%, 5 \%$ and $10 \%$ level.

For the model with no inclusion of a holiday dummy variable, in the case of the USA, the results showed that, when it comes to seasonal pull factors, only the variable wind in Aruba was significant in determining the short-term seasonal factor of US tourism demand. An increase in the seasonal factor of wind in Aruba would increase the seasonal factor of tourism demand from the USA, most likely reflecting the attractiveness of the cooling effect of wind in a warm environment (Scott \& McBoyle, 2001). In the same setting, the coefficients of the seasonal push factors, rainfall and wind speed in the USA, were also positive, indicating that increases in the seasonal factors of rainfall and wind speed in the USA would have a positive effect on the seasonal factor of US tourism demand for Aruba. The thermal effect can explain the positive effect of the increase in the seasonal factor of wind speed on that of tourism demand from the USA it has on people, particularly when it comes to wind chills in cold climates (Scott \& McBoyle, 2001). On the other hand, the seasonal factor 
of temperature in the USA has a negative impact on the seasonal factor of tourism demand from that country to Aruba. In other words, short-term increases in the seasonal factors of temperature in the USA would have a negative impact on the short-term seasonal factor of tourism demand from that country, given that the push effect of this seasonal factor becomes smaller as temperatures increase in the USA.

In the case of Venezuela, initial estimates showed that the seasonal factors of temperature and wind in that country did not show the expected outcomes, while both factors were statistically significant. For this reason, both variables were excluded from the regression, and the re-estimated coefficients showed that the seasonal factors of both rainfall and temperature in Aruba were significant pull influences at, respectively, the $1 \%$ and the $10 \%$ level of significance. Furthermore, the seasonal factor of rainfall in Venezuela has a positive impact on the seasonal factor of tourism demand from that country. In other words, the increased effects of seasonal rainfall in Venezuela will likely have a positive effect on the seasonal factor of tourism demand from that country.

Next, we added the holiday dummies in both regressions, and the first notable effect of doing this is that of what is called dummy trap in the case of the fixed-effect model, where there is most likely interaction between the added dummy and the fixed effect dummies. Therefore, the fixed-effect model cannot be used under the new condition. Hence, we resorted to the REM for estimating the model which includes the holiday dummy variable. The results are also included in Table 2.5. In the case of the USA, the holiday dummy variable was significant, meaning that the seasonality of vacations and holidays was a determining factor in the tourism demand seasonality of US visitors. This significance may be explained by the relatively low number of paid vacation days that Americans have compared with other nations (on average ten paid vacation days and six paid holidays in the private sector, according to a study 
by the Center for Economic and Policy Research (Ray, Sanes, \& Schmitt, 2013). Furthermore, the pull seasonal factors of cloud coverage and wind speed in Aruba were important determinants of the seasonal factor of US tourism demand both at the $1 \%$ level of significance. In the case of push seasonal factors, rainfall, temperature, and wind speed were statistically significant (at, respectively, the 5\%,10\% and 5\% level of significance) in influencing the seasonal pattern of tourism demand from the USA.

The results for Venezuela show that holiday vacations were not statistically significant, which might be explained by the number of paid vacation days that Venezuelans have (a minimum of 15 days, and one additional day each year of service, up to a maximum of 30 days (http://www.lottt.gob.ve)). Additionally, Venezuelans have a maximum of 12 public holidays, provided that they fall on a weekday. Theoretically, a Venezuelan worker could have up to 42 days of paid vacation and holiday, making it easier than for the US visitors to come to Aruba, even more than once a year. The available data suggest that $78 \%$ of Venezuelans who patronize Aruba are repeat visitors, and $37 \%$ of the Venezuelan repeat tourists have visited the island more than six times (Croes, Rivera, Pizam, Olsen, Lee, \& Zhong, 2011), indicating that Venezuelan travelers are likely to have experience with the possible climate patterns on the island. Further results show that particularly rainfall and temperature in Aruba (with respective significance statistics of $1 \%$ and 5\%) were essential pull factors for the seasonal travel behavior of Venezuelan visitors to the island. Additionally, the seasonality of rainfall in Venezuela itself was an important influence on the seasonal factor of tourism demand from that country. 
The EDMs were subsequently calculated for the statistically significant seasonal factors of climate and seasonal tourism demand patterns. The results are reported in Charts 2.1-2.8 (Figure 2.3), showing different degrees of sensitivity of seasonal patterns of tourism demand to seasonal climate factors. To complement the charts, we also included in Table 2.6 the months where the EDM outcomes were smaller than the average, as a proxy for when the sensitivity of the seasonal factors of tourism demand to those of climate was the highest. In the case of the USA, sensitivity to the pull and push seasonal factors of climate was most pertinent in February, August, September, and November, with both the respective pull and push seasonal factors being implicated most of the time as influencing factors on the sensitivity. The sensitivity may suggest that vacation patterns may be more dominant in determining movements in the seasonal factors of tourism demand in the remaining months of the year. It may also suggest the effect of a possible third factor, which is the seasonality of the timeshare component, where tourists come in a particular month of the year to make use of their timeshare ownership. 

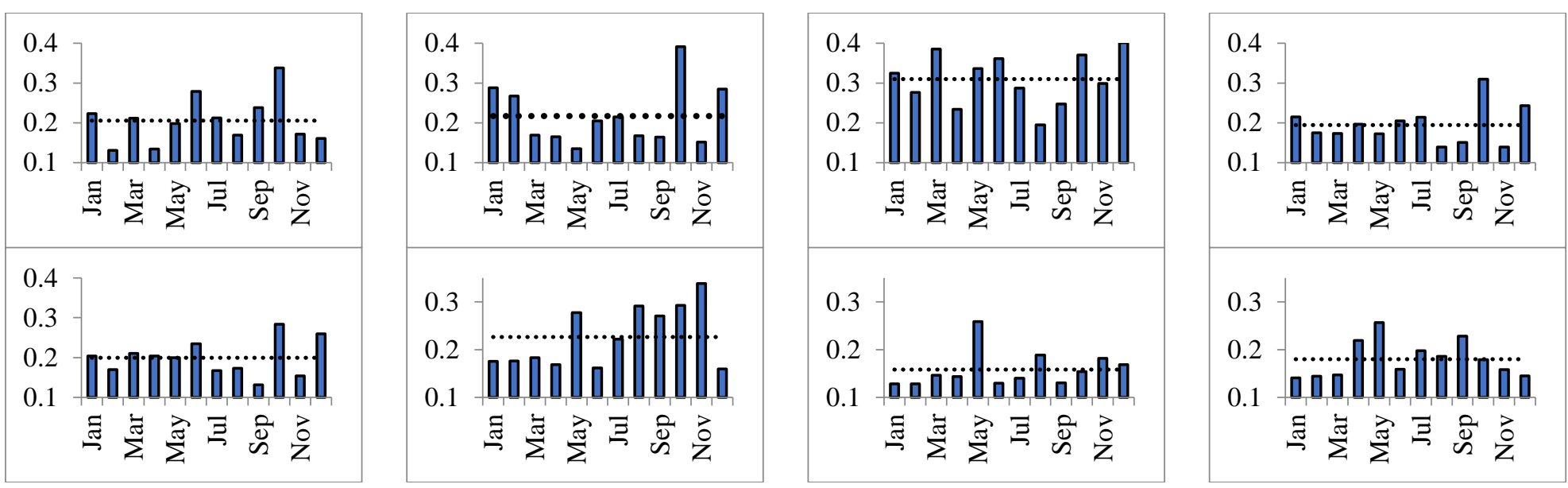

Figure 2.3: Chart 2.1: Euclidean distance of cloud coverage in Aruba and tourism demand from the USA. Chart 2.2: Euclidean distance of wind speed in Aruba and tourism demand from the USA. Chart 2.3: Euclidean distance of rainfall in the USA and tourism demand from the USA. Chart 2.4: Euclidean distance of temperature in the USA and tourism demand from the USA. Chart 2.5: Euclidean distance of wind speed in the USA and tourism demand from the USA. Chart 2.6: Euclidean distance of rainfall in Aruba and tourism demand from Venezuela. Chart 2.7: Euclidean distance of temperature in Aruba and tourism demand from Venezuela. Chart 2.8: Euclidean distance of rainfall in Venezuela and tourism demand from Venezuela. 
According to the Aruba Timeshare Association, almost $40 \%$ of the overall hotel inventory in Aruba consists of timeshare units, and approximately 300,000 timeshare members (and exchangers) - or nearly 50\% of all guests to Aruba - visit the island on an annual basis (http://www.arubatimeshare.net). This share may explain why the sensitivity of the seasonal factor of US tourism demand was low concerning both pull and push climate patterns.

In the case of Venezuela, the seasonal factor of tourism demand was more influenced by climate patterns in the first half of the year, except for May, where the sensitivity was low in all climate circumstances. Further low sensitivities were found mainly in the second half of the year, possibly explained by the dominating role of what is known as the 'lock-in effect' in these months. The lock-in effect refers to tourists' preference for spending their holidays in conventional, well-known destinations, even when there are changes in the climate (Faulkner, 2000; Moreno Sánchez, 2010). The fact that the previously-mentioned characteristics of a vast majority of Venezuelan visitors (i.e., more than $3 / 4$ being repeat visitors, with slightly more than $1 / 3$ of them having multiple-visit experience) may corroborate the possibility of the lock-in effect existing for this market.

The previous analysis reveals that short-term mutations in tourism demand from both the USA and Venezuela are impacted by both pull and push seasonal climate factors. However, these impacting effects are not homogeneous, meaning that they can vary in intensity, depending on the type of climate variable and the time of year. This heterogeneity of climate impacts on tourism demand presents opportunities for improving the management of short-run tourism development. 
Table 2.6: Months where the EDM is below average.

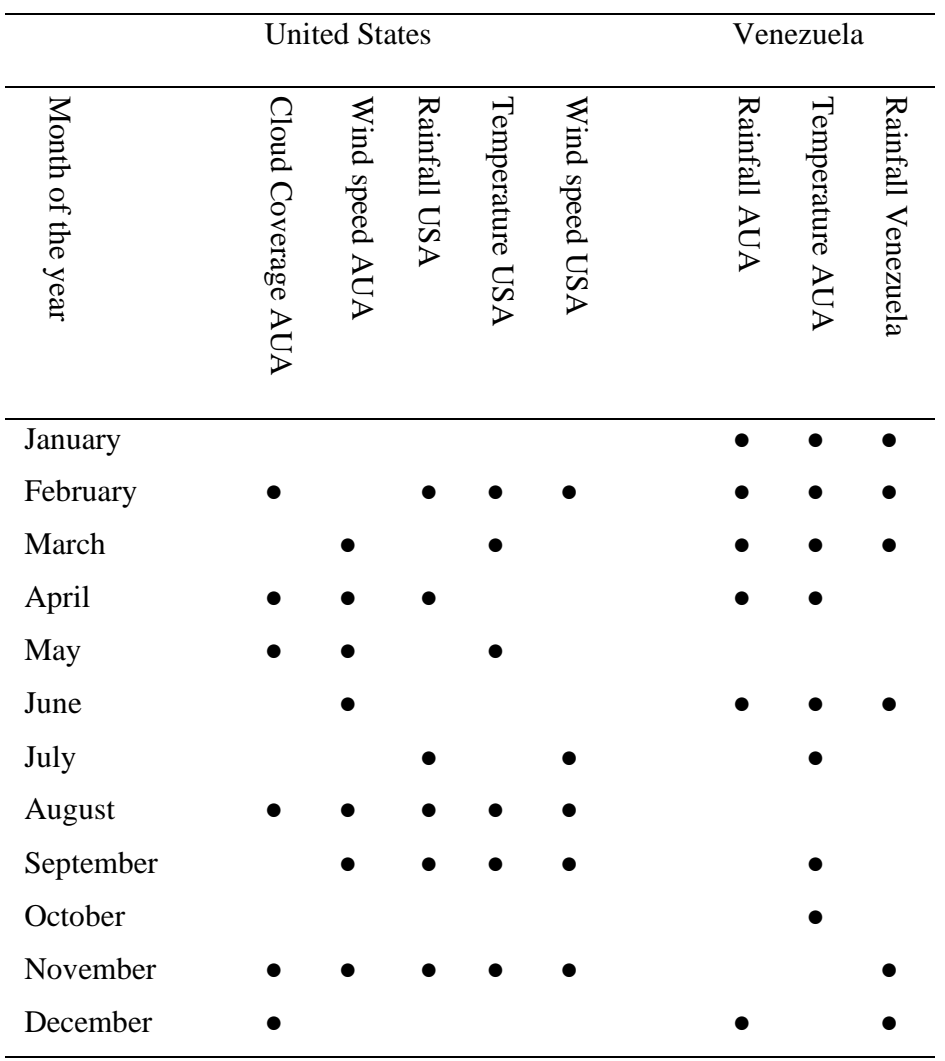

Note: $\bullet$ indicates that the EDM outcome is below its average

\subsection{Conclusion}

Climate is possibly the third-most important attribute in tourists' decisionmaking process, next to the aquatic and natural attributes of a destination (Hamilton \& Lau, 2004). This study has investigated the influence of seasonal patterns of pull and push climate on the seasonal fluctuations of tourism demand for Aruba. According to Yu et al. (2010), working only with seasonal factors facilitates a more efficient examination of the impacts of the specific weather influences on tourism demand variability, i.e., by filtering out 'noise,' and so a better understanding of the nature of the relationships. The applied 
data showed that seasonal factors significantly influenced the overall shortterm behavior of tourism demand from both the USA and Venezuela, thus legitimizing the seasonal approach followed in this study. The results show that both pull and push seasonal factors of climate were relevant in determining the seasonal variations in tourism demand from both countries. In the case of the USA, the seasonal factors of cloud coverage and wind speed in Aruba were important pull factors, while rainfall, temperature, and wind speed in the USA were key push factors. For Venezuela, the two essential climate pull factors were rainfall and temperature in Aruba, while rainfall in Venezuela was a paramount push factor.

Moreover, short-term movements in tourism demand from the USA were also impacted by vacations and holidays (probably influenced by the limited number of paid leave days that many Americans have), while the timeshare factor could be a third impacting element in the seasonal behavior of US tourists. In the case of Venezuela, the findings do not suggest a significant role for vacations and holidays, but the fact that many Venezuelans have multitime experience with Aruba as a tourist destination may suggest the impact of the lock-in effect as a secondary factor that influences the short-term variations in tourism demand from this country.

While this study suggests that climate in Aruba is an imperative factor determining short-term movements in tourism demand, climate conditions on the island are also important in determining long-term tourism demand. For example, a study by Sookram (2011), based on annual data, found that temperature and rainfall in Aruba influenced US tourism demand for this destination, in addition to per capita income, and the gross domestic product in the USA.

The findings of this study are important because they shed light on the combined influence of seasonal variations of push and pull weather elements on the seasonal deviations of tourism demand. Moreover, the results show that 
monitoring economic factors alone is not enough when it comes to analyzing the short-term determinants of tourism demand for Aruba. Climate patterns matter for travelers from both the USA and Venezuela to Aruba. Knowledge about the structure of the climate variations over the year could assist tourism managers and government representatives to (better) cope with short-term demand fluctuations in their planning, forecasting, and marketing efforts.

Furthermore, distinguishing between the climate sensitivities of the markets could assist people involved with tourism development to build a complementary relationship between these two types of markets in order to minimize the fluctuation in tourism demand over the year. For example, one possible strategy that policymakers and tourism leaders could follow would be to keep an eye on longer-term weather forecasts, such as that of the National Oceanic Atmospheric Administration Climate Prediction Center (http://www.cpc.ncep.noaa.gov) in order to get a lead on expected seasonal weather conditions in the North-Eastern USA. For instance, if the temperature during the winter season is projected to be higher than normal, then the likelihood of lower demand from the North-Eastern USA increases. The latter could be the case in, for example, February, where the intensity of the seasonal factor of temperature in the North-Eastern USA is the highest in the winter season. Policymakers and tourism chiefs in Aruba could react to this information by first comparing bookings for this month against a year earlier. If these do indeed point to lower demand, policymakers could then react by making more special offers available for this period to counter the expected low demand. Alternatively, they could increase marketing efforts from other markets (e.g., Venezuela) to stimulate demand, thereby compensating for the expected fall-down in demand from the North-Eastern USA. It is important to mention is that the current marketing plan of the Aruba Tourism Authority (Croes et al., 2011) does not include a strategy on the interactions between 
markets in terms of mitigating the adverse demand effects of push climate factors.

Given that climate conditions in Aruba are essential in pulling demand from both the USA and Venezuela, a continuous stream of general information on current and average climate conditions during the year is needed, thus providing an additional economic benefit from public weather and climate services. Visitors can find a link with the Meteorological Department of Aruba, which provides short-term and long-term forecasts that could be used for planning purposes. However, many hotels do not themselves provide information on (average) weather conditions on the island, which could be important complementary information for the visitor in the planning process. It is recommended that all hotels should incorporate up to date local weather information on their websites, derived from the official meteorological sources. The theoretical implications are twofold. First, climate is a significant push and pull factor affecting tourism demand. Second, tourism demand and climate are bounded by intertemporal climate constraints. Future research should focus on extending this investigation to include other destination markets for Aruba, such as the European countries, in order to obtain a complete picture of the influence of seasonal pull and push weather on recurrent tourism demand for the island. Moreover, this study could be expanded to include other destinations in the Caribbean, to compare weather effects in terms of impacts and timing on the demand from similar tourism markets in other Caribbean destinations. It makes good sense to have a thorough understanding of the development of tourism demand during the year, including the factors that determine its pattern. 


\section{References}

Amelung, B., Nicholls, S., \& Viner, D. (2007). Implications of global climate change for tourism flows and seasonality. Journal of Travel Research, 45, 285-296.

Asteriou, D. (2006). Applied Econometrics--A Modern Approach Using Eviews and Microfit. Palgrave MacMillan New York.

Beaulieu, J., \& Miron, J. (1993). Seasonal unit roots in aggregate US data. Journal of Econometrics, 55(1), 305-328.

Behringer, J., Buerki, R., \& Fuhrer, J. (2000). Participatory integrated assessment of adaptation to climate change in Alpine tourism and mountain agriculture. Integrated Assessment, 1, 331-338.

Belén Gómez Martín, M. (2005). Weather, climate and tourism, A geographical perspective. Annals of Tourism Research, 32(3), 571-591.

Berrittella, M., Bigano, A., Rosen, R., \& Tol, R. (2006). A general equilibrium analysis of climate change impacts on tourism. Tourism Management, 27, 913-924.

Bicak, H., Altinay, M., \& Jenkins, H. (2005). Forecasting the tourism demand of North Cyprus. Journal of Hospitality \& Leisure Marketing, 12(3), 87-99.

Bigano, A., Goria, A., Hamilton, J., \& Tol, R. (2005). The effect of climate change and extreme weather events on tourism. Working Paper 30.2005 Fondacione Eni Enrico Mattei.

Buckley, L., \& Foushee, M. (2012). Footprints of climate change in US national park visitation. International Journal of Biometeorology, 56(6), 1173-1177.

Butler, R. (2001). Seasonality in Tourism: Issues and Implications. In T. Baum, \& S. Lundtrop, Seasonality in Tourism (pp. 5-21). Elsevier, Ltd.

Butter, F. d., \& Fase, M. (1988). Seizoensanalyse en beleidsdiagnose. De Nederlandsche Bank, Amsterdam.

Chan, F., \& Lim, C. (2011). Spectral analysis of seasonality in tourism demand. Mathematics and Computers in Simulation, 81, 1409-1418.

Coombes, E., \& Jones, A. (2010). Assessing the impact of climate change on visitor behavior and habitat use at the coast: A UK case study. Global Environment, 20, 303-313.

Croes, R. (2010). Anatomy of Demand in International Tourism, The Case of Aruba. Saarbrucken: Lambert Publication.

Croes, R., \& Vanegas Sr., M. (2005). An econometric study of tourist arrivals in Aruba and its implications. Tourism Management, 26, 879-890.

Croes, R., Rivera, M., Pizam, A., Olsen, E., Lee, S., \& Zhong, Y. (2011). Winning the Future, Strategic Plan for the Development of Tourism. Ministry of Tourism Transportation and Labour.

Cuccia, T., \& Rizzo, I. (2011). Tourism seasonality in cultural destinations: Empirical evidence from Sicily. Tourism Management, 32, 589-595. 
Departamento Meteorologico Aruba. (2012). 2012: Beknopt overzicht van het klimaat van Aruba.

Dritsakis, N. (2008). Seasonal analysis of tourist revenues: An empirical research for Greece. Tourismos: An International Multidisciplinary Journal of Tourism, 3(2), 57-70.

Eisenhardt, K., \& Graebner, M. (2007). Theory building from cases: Opportunities and challenges. Academy of Management Journal, 50(1), 25-32.

Farooque, G. (2003). Effects of transformation choice on seasonal adjustment diagnostics and forecast errors. Report the result of research and analysis undertaken by US Census Bureau, Washington DC. Retrieved August 20, 2012, from http://www.fcsm.gov/03papers/Farooque.pdf.

Faulkner, B. (2000). "The future ain't what it used to be," coping with change, turbulence and disasters in tourism research and destination management. Griffith University Public Lecture Series, August 2000, Gold Coast, Qld.

Franses, P. (1990). Testing for Seasonal Unit Roots in Monthly Data. Report 9032/A. Econometric Institute, Erasmus University Rotterdam.

Goh, G. (2012). Exploring the impact of climate on tourism demand. Annals of Tourism Research, 39(4), 1859-1883.

Gujarati, D. (2012). Econometrics by Example. Palgrave MacMillan New York.

Hadwen, W., Arthington, A., Boon, P., Taylor, B., \& Fellows, C. (2011). Do climatic or institutional factors drive seasonal patterns of tourism visitation to protected areas across diverse climate zones in Eastern Australia? Tourism Geographies: An International Journal of Tourism Space, Place and Environment, 13(2), 187-208.

Hamilton, J., \& Lau, M. (2004). The role of climate information in tourist destination choice. Working Paper FNU-56.

Hamilton, J., Maddison, D., \& Tol, R. (2005). Climate change and international tourism: A simulation study. Global Environmental Change, 15, 253266.

Hamilton, J., \& Tol, R. (2007). The impact of climate change on tourism in Germany, the UK and Ireland: A simulation study. Regional Environment Change, 7, 161-172.

Hylleberg, S., Engle, R., Granger, C., \& Yoo, B. (1990). Seasonal integration and cointegration. Journal of Econometrics, 44(1), 215-238.

Im, K., Pesaran, M., \& Shin, Y. (2003). Testing for unit roots in heterogeneous panels. Journal of Econometrics, 115(1), 53-74.

International Monetary Fund. (2000). Seasonal adjustment and estimation. International Monetary Fund. Retrieved July 10, 2013, from http://www.imf.org/external/pubs/ft/qna/2000/textbook/ch8.pdf. 
Karamustafa, K., \& Ulama, S. (2010). Measuring the seasonality in tourism with the comparison of different methods. Euromed Journal of Business, 5(2), 191-214.

Kulendran, N., \& Dwyer, L. (2010). Seasonal Variation Versus Climate Variation for Australian Tourism. CRC for Sustainable Tourism Pty Ltd.

Lim, C. (1997). Review of international tourism demand models. Annals of Tourism Research, 24(4), 835-849.

Lohmann, M. \& Kaim, E. (1999). Weather and holiday destination preferences image, attitude and experience. Tourism Review, 54(2), 54-64.

Makridakis, S., Wheelwright, S., \& McGee, V. (1983). Forecasting Methods and Applications (2nd ed.). New York: John Wiley \& Sons.

Matzarakis, A. (2006). Weather- and climate-related information for tourism. Tourism and Hospitality Planning \& Development, 3(2), 99-115.

Moreno Sánchez, A. (2010). Mediterranean tourism and climate (Change): A survey-based study. Tourism and Hospitality Planning \& Development, 7(3), 253-265.

Pegg, S., Patterson, I., \& Vila Gariddo, P. (2012). The impact of seasonality on tourism and hospitality operations in the Alpine region of New South Wales, Australia. International Journal of Hospitality Management, 31, 659-686.

Petrevska, B. (2012). Forecasting international tourism demand: The evidence from Macedonia. UTMS Journal of Economics, 3(1), 45-55.

Ray, R., Sanes, M., \& Schmitt, J. (2013). No-Vacation Nation Revisited. Center for Economic and Policy Research. Center for Economic and Policy Research. Retrieved July 17, 2013, from

http://www.cepr.net/documents/publications/no-vacation-update-201305.pdf.

Ridderstaat, J. (2007). The Lago Story, The Compelling Story of an Oil Company on the Island of Aruba. Editorial Charuba.

Rodrigues, P., \& Franses, P. (2005). A sequential approach to testing seasonal unit roots in high frequency data. Journal of Applied Statistics, 32(6), 555-569.

Scott, D. \& Lemieux, Chr. (2009). Weather and Climate Information for Tourism. World Meteorological Organization and United Nations World Tourism Organization.

Scott, D., \& McBoyle, G. (2001). Using a 'Tourism Climate Index' to Examine the Implications of Climate Change for Climate as a Tourism Resource. In A. Matzarakis, \& C. de Freitas (Eds.), Proceedings of the First International Workshop on Climate, Tourism and Recreation, (pp. 69-88). Retrieved July 16, 2013, from

http://www.mif.uni-freiburg.de/ISB/ws/papers/full_report.pdf\#page=73. 
Scott, D., McBoyle, G., \& Schwartzentruber, M. (2004). Climate change and the distribution of climatic resources for tourism in North America. Climate Research, 27, 105-117.

Shareef, R., Suhejla, H., \& MacAleer, M. (2008). The Economics of Small Island Tourism: International Demand and Country Risk Analysis. Edward Elgar Publishing.

Soboll, A., \& Dingeldey, A. (2012). The future impact of climate change on Alpine winter tourism: A high-resolution simulation system in the German and Austrian Alps. Journal of Sustainable Tourism, 20(1), 101-120.

Song, H., \& Li, G. (2008). Tourism demand modelling and forecasting-A review of recent research. Tourism Management, 29, 203-220.

Song, H., Dwyer, L., Li, G., \& Cao, Z. (2012). Tourism economics research: A review and assessment. Annals of Tourism Research, 39(3), 16531682.

Song, H., Witt, S., \& Li, G. (2009). The Advanced Econometrics of Tourism Demand. Routledge, London.

Sookram, S. (2011). An Assessment of the Economic Impact of Climate Change on the Tourism Sector in Aruba. Economic Commission for Latin American and the Caribbean (ECLAC).

Stiglitz, J., Sen, A., \& Fitoussi, J. (2009). Report by the Commission on the Measurement of Economic Performance and Social Progress. Retrieved April 12, 2010, from (http://www.unstats.un.org).

UNWTO, \& UNEP. (2008). Climate Change and Tourism, Responding to Global Challenges.

Vanegas Sr., M., \& Croes, R. (2000). Evaluation of demand, US tourists to Aruba. Annals of Tourism Research, 27(4), 946-963.

Yin, R. (2009). Case Study Research, Design and Methods (4th ed.). Sage Publications, Inc.

Yu, G., Schwartz, Z., \& Walsh, J. (2009). Effects of climate change on the seasonality of weather for tourism in Alaska. Arctic, 62(4), 443-457.

Yu, G., Schwartz, Z., \& Walsh, J. (2010). Climate change and tourism seasonality. Journal of Tourism, VI(2), 51-65. 


\title{
3. Impacts of cyclic patterns of climate on fluctuations in tourism demand. Evidence from Aruba ${ }^{l}$
}

\begin{abstract}
This study estimates the influence of cyclical climate patterns of pull and push climate elements (rainfall, temperature, wind) on cyclical fluctuations in tourism demand from the United States, the Netherlands, and Venezuela on a small island state. Two important atmospheric variabilities, the El Niño Southern Oscillation (ENSO) and the North Atlantic Oscillation (NAO), were also included. Wavelet analysis was used because meteorological and economic time-series are typically noisy, complex, and strongly non-stationary. Results show that both pull and push cyclical climate factors had an influence on tourism demand from the USA, the Netherlands, and Venezuela. Furthermore, ENSO and NAO also had an influence on tourism demand from the USA and the Netherlands. Finding a statistical link between atmospheric variability and tourism suggests that this should be taken into account in the development of tourism demand models in order to simplify econometric models.
\end{abstract}

Keywords cyclic pattern, tourism demand, wavelet analysis, Aruba, El Niño, North Atlantic Oscillation.

1. This chapter is based on Oduber, M., \& Ridderstaat, J. (2017). Impacts of Cyclic Patterns of Climate on Fluctuations in Tourism Demand: Evidence from Aruba. Journal of Tourism Research and Hospitality, 6(1), 1-10. 


\subsection{Introduction}

The purpose of the study is to investigate how cyclical patterns of climate influence tourism demand in small island destinations. Climate and weather play detrimental roles in the selection process of a tourist destination. Studying climate cycles relationship to tourism cycle may provide a better understanding of the complicated process of tourist visit fluctuations on a destination. Cycles are generally defined as systematic variations that have the property of repetition (Kožić, 2014). In this context, for example, a business cycle can be defined as a fluctuation of economic activity that shows a nonseasonal pattern. Some business cycles are the Kitchin cycle, the Juglar cycle, the Kuznets cycle, and the Kondratieff cycle (Kožić, 2014). Kitchin cycles are short-period cycles of 3 to 5 years, Juglar cycles are 7 to 11 years, Kuznets cycles are 15 to 25 years, whereas Kondratieff is the longer cycles of 45 to 60 years. Tourism demand cycles could, in an economic sense, be considered as a result of variations of the overall economic activity. Therefore, according to Kožić (2014), tourism demand cycles can be explained by the influence of the overall economic activity. Studies conducted by Guizzardi and Mazzocchi (2010), also indicate that tourism cycles can be heavily influenced by the overall business cycle. Where Gouveia and Rodrigues (2005), found the presence of a repetitive time lag among turning points of business and tourism demand growth cycles. Certain authors have also tried to relate money supply cycles in destination countries with tourism demand cycles in the arrival country (Ridderstaat \& Croes, 2017). These authors showed that money supply cycles can influence the cyclical movements of tourism demand and that the impacts are asymmetric depending on the time of development of the cycles (Ridderstaat \& Croes, 2017).

Over the past century, tourism has become the world's biggest business, exceeding defense, manufacturing, oil, and agriculture industries (Lundberg, Krishnamoorthy, \& Stavenga, 1995; Goeldner \& Ritchie, 2012). 
Tourism is one of the fastest-growing segments (Vanhove, 2005; Salish \& Rodrigues, 2011; Schubert \& Brida, 2011), and this is a unique feature since World War II (Apostolopoulos, 1996). To stay up-to-date to the rapidly growing tourism phenomenon, destinations must have proper projections of tourism demand for planning and managerial decisions. Therefore an adequate insight into the factors that influence tourism is needed. These factors should also include non-economic factors. Most studies on the determinants of tourism demand have been focused around economic aspects (e.g., income and price), while remaining mostly silent on the potential impact of climate on the selection of destinations (Ridderstaat, Oduber, Croes, Nijkamp, \& Martens, 2014). Climate is defined as the total of all statistical weather information that aids in describing the variation of weather at a given place for a specified interval of time (Geer, 1996). Climate can be seen as the average weather for a particular location that influences a wide array of environmental resources, which are critical attractions for tourism, for example, snow conditions, wildlife productivity and biodiversity, and water levels and their quality (UNWTO \& UNEP, 2008). On the other hand, the weather is the state of the atmosphere, mainly concerning its effect upon life and human activities at a particular time, as defined by the various weather elements (Geer, 1996).

Since the beginning of reliable instrumental records, it has been possible to make approximations of the degree to which various aspects of economic activity have been influenced by anomalous weather events (Burroughs, 2003). Severe winters of 1947, 1963, and 1979 all have caused major economic disruptions across Europe (Burroughs, 2003). Cyclic behavior in the climate such as El Niño's of 1982/83 and 1997/98 had major global impacts. From droughts in Australia to any part of sub-Saharan Africa, Brazil, and Central America (Burroughs, 2003). Except for economic impacts, the climate can influence tourism too. Climate can attract visitors who expect pleasant weather conditions at a destination (Belén, 2005; Scott, McBoyle, \& 
Schwartzentruber, 2004). While on the other hand, the climate can influence a traveler's decision to leave or stay in his/her own country (Hamilton \& Tol, 2007). Henceforth, the climate can act as both a pull and a push factor that influences the motivations of tourists to go on a holiday and how they choose their destination of preference (Hamilton, Maddison, \& Tol, 2005; Amelung, Nicholls, \& Viner, 2007).

Reduction in demand can induce conditions such as overcapacity, nonutilization of infrastructure, decrease in the workforce, and absence of investments during low seasons (Pegg, Patterson \& Gariddo, 2012), which can induce reduced profitability and productivity (Karamustafa \& Ulama, 2010). In contrast, peak seasons of tourism can be characterized by overuse of public utilities (e.g., water supply, waste management, and road use), causing discontent for inhabitants and visitors alike, while the environment can suffer permanent damage because of tourism burdens (Cuccia \& Rizzo, 2011).

Studies on climate and tourism, such as Ridderstaat et al. (2014), and Agnew, and Palutikof (2006) have focused on the seasonal patterns, intraannual, inter-annual scales of climate and not cyclic patterns. Others have used climatological data in order to investigate general tourism activities for a region, but not long cyclic events and tourism itself (Çaliskan \& Kelkit, 2008). A study done by Moreno, Amelung, and Santamarta (2008) has reviewed the relationship between weather conditions and beach recreation by studying tourists' behavior. In their study, they used daily weather conditions and webcam data to get an idea of the movement of tourists in a particular area. Here again, the focus was on shorter term climate patterns that influence the movement of tourists, not on cyclic events that influence tourism demand.

Furthermore, Álvarez-Díaz, Giráldez, and González-Gómez (2010) indicate that in general little systematic research has been done on climate as a significant determinant of tourism demand. Álvarez-Díaz et al. (2010) indicate that only recently, several studies have analyzed the impact of climate and 
weather variables on tourism. Álvarez-Díaz et al. (2010), themselves have studied as a novum, the North Atlantic Oscillation (NAO) and variability on tourism arrivals from the United Kingdom and Germany to Spain.

To our knowledge, the study by Ridderstaat et al. (2014) was the only one that has studied how seasonal push and pull climate patterns can influence seasonal movements of tourism demand on a small island. Given the lack of studies that investigate how cyclical climate patterns influence cyclical patterns of tourism demand, especially in small island destinations, there is a case for a better understanding of the drivers of tourism demand in small island economies. Croes (2006) shows that many small islands use tourism development as a growth strategy for higher economic and development performance. The positive contribution from specializing in tourism has aided to more than balance the negative impact of being a small island economy, and tourism has been a significant contributor to lower output volatility in many countries (Thacker, Mejia, \& Perrelli, 2012).

This study investigates whether cyclic patterns of pull and push climate elements (including rainfall, wind, and temperature) affect the cyclical deviations of tourism demand for a small destination like Aruba. Individual case studies can contribute to scientific generalizations through the replication outcome, where the mode of generalization is an analytic generalization (Yin, 2009). The aim then is to develop and generalize theories, and not to enumerate frequencies (statistical generalizations). According to Eisenhardt and Graebner (2007), building theory from case studies is a research strategy, which requires at least one case to create theoretical, constructs, propositions and/or midrange theory from case-based empirical evidence.

The methodology involves a wavelet analysis of tourism demand and climate factors. Wavelet analysis comprises of transformations of a data series through a wavelet, and a localized wave (Johansson, Cummings, \& Glass, 2009). The data is rearranged into a frequency domain, where periodic 
behavior is more easily seen (Johansson et al., 2009). Wavelet analysis is well suited for studies of multiscale, non-stationary processes that occur over finite spatial and temporal domains (Lau \& Weng, 1995). In the case of tourism demand and climate factors, it can differentiate multi-annual patterns of variation from a seasonal component. Wavelet analysis is also coherence in which the frequency components of different time-series can be compared directly (Johansson et al., 2009). Therefore wavelet analysis gives two major benefits: first, it allows separation of influences by time-scale, and secondly, it gives a domain in which to measure nonstationary association (Johansson et al., 2009).

The present study allows for some key contributions to the tourism literature. Firstly it adds to the further understanding of the specific role of patterns of cyclic climatic variables on the cyclic pattern of tourism demand. Secondly, this investigation also simultaneously analyses the impact of both pull and push climate factors on cyclical tourism demand movements on a small island, which, as far as we can perceive, is not common when it comes to time-series based studies on this relationship. The rest of this paper is organized as follows. Section 3.2 discusses the material and methods. In section 3.3, results and discussion are presented, whereas section 3.4 concludes and offers policy implications and lines for future research. 


\subsection{Materials and Methods}

\subsubsection{Case study Aruba}

Aruba is a small island state positioned about $32 \mathrm{~km}$ from the Northern coast of Venezuela and has only an area of about $180 \mathrm{~km}^{2}$. Aruba is considered as an autonomous country within the Kingdom of the Netherlands, which consists of The Netherlands, Aruba, Curacao and Saint Maarten. Aruba's capital is Oranjestad, and Aruba's total population is around 110 thousand (Central Bureau Statistic, 2016). Aruba is popularly referenced also as part of the ABC islands, which consists of Aruba, Curacao, and Bonaire.

Unlike many other islands in the Caribbean, Aruba has an arid and windy climate. Aruba's climate is classified as a tropical steppe, hot semiarid climate with the wind coming for more than $95 \%$ of the time from the northeast and the southeast direction over Aruba, with an average speed of $7.3 \mathrm{~m} \mathrm{~s}^{-1}$ at a 10-meter distance (1981-2010) (Oduber, Ridderstaat, \& Martens, 2015). On average, Aruba's temperature is $27.9^{\circ}$ Celsius, but the temperature can fluctuate between $19.0^{\circ}$ Celsius to $36.5^{\circ}$ Celsius. The average rainfall for Aruba for the period (1981-2010 is $471.1 \mathrm{~mm}$ (Oduber et al., 2015). Even though Aruba has a dry and windy climate, the island still has managed to become a popular tourist destination.

Aruba has a bit more than half a century of experience with the tourism industry. Its first 100-room hotel was built in 1959 and modeled after similar ones in Florida and Puerto Rico (Ridderstaat et al., 2014). Given the dominant role of the Lago Oil \& Transport Company, Ltd, tourism played only a small part in the overall economic development of the island in the beginning. This situation changed in 1985 when the oil refinery closed its doors and causing a considerable shock to the Aruban economy (Ridderstaat, 2007). This precarious situation forced the Aruban government to search for new sources of economic activity. The most tangible way was to expand the tourism industry. The number of hotel rooms more than tripled, from 1986 to 2011, where the 
majority of visitors came by airplane (Ridderstaat et al., 2014). The United States tourist accounted on average for roughly $63.5 \%$ of all stay-over visitors between 1981-2011; this makes the United States the biggest market for Aruba. The Venezuelan market is the second largest for the island, accounting on average for about $13 \%$ of all stay-over visitors to the island (Ridderstaat et al., 2014).

\subsubsection{Data collection}

The basis for this study is the conceptual scheme depicted in Figure 3.1, where relationships will be investigated between, on the one hand, push climate patterns, on the other hand, pull climate patterns, and tourism demand, in the middle. Matzarakis (2006), shows that the most relevant meteorological parameters when it comes to tourism include air temperature, air humidity, wind speed, wind direction, cloud coverage, sunshine duration, or radiation fluxes, rain and precipitation, snow coverage, and water temperature. For this study, we use three meteorological parameters (rainfall, temperature, and wind speed) as pull factors (i.e., the climate conditions in arrival country that attract visitors), and three meteorological factors (rainfall, temperature, and wind speed) as push factors (i.e., climate conditions departure country that cause residents to travel to destinations like Aruba). 


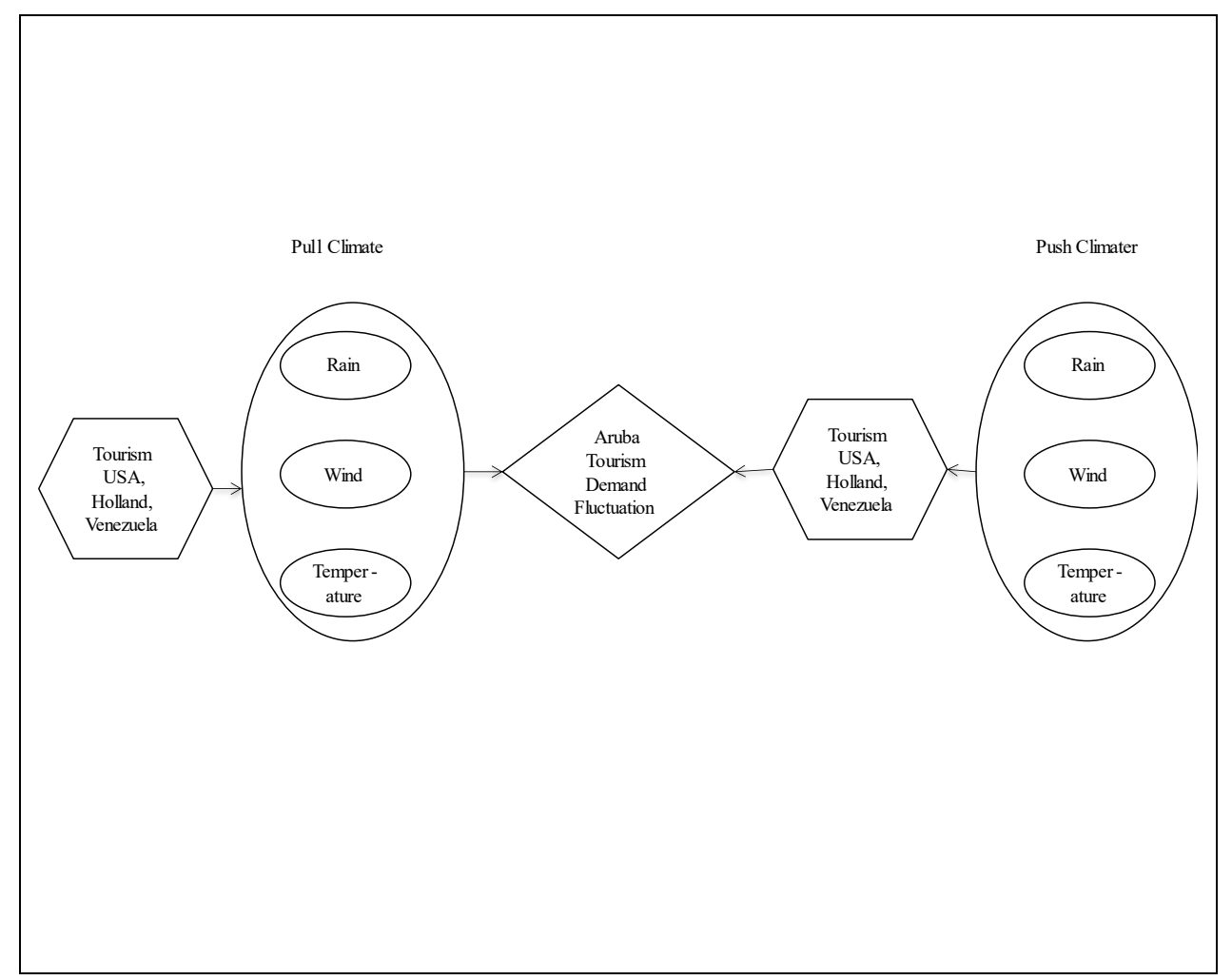

Figure 3.1: Conceptual framework of the relation between the cyclical patterns of (pull/push) climate data and tourism demand of Aruba's tourism.

The raw variables used in this investigation are shown in Table 3.1. Climate data for Aruba are from the Meteorological Department of Aruba. The related data for the USA are from the North-Eastern part of that country, given that most US visitors to Aruba are from that region. The climate data for this country comes from several sources, including the Global Precipitation Climatology Centre and the European Centre for Medium-Range Weather Forecasts. Climate data for the Netherlands and Venezuela (Caracas) are from the same sources as those of the USA. Tourism demand is approximated by the number of visitors from the Netherlands, the North-Eastern part of the USA, and Venezuela. The data were collected from the Central Bank of Aruba. 


\subsubsection{Wavelet analysis}

Meteorological and economic data can be substantially non-stationary (Lau \& Weng, 1995) (Geda, 2015). Therefore the authors performed wavelet decomposition, which is a statistical analysis on time-series allowing for efficient dealing with non-stationary data. In order to perform wavelet analysis, one has to choose a basic function for the transformation. For this study, we used the Morlet wavelet, which is a complex sine wave localized by a Gaussian distribution according to the following formula

$\psi_{0}(\eta)=\pi^{-1 / 4} e^{i \omega 0 \eta} e^{\eta^{2} / 2}$

where $\eta$ is a scaled time variable, describing the relative frequency $\omega 0$ of the sine wave (Johansson et al., 2009). We used a non-dimensional frequency $\omega 0=$ 6, which is used in ecological, geophysical and economic studies (Grinsted, Moore, \& Jevrejeva, 2004; Do, Martens, Luu, Wright, \& Choisy, 2014; Rua, 2012). The continuous wavelet transform consists of the convolution of the series $x_{\mathrm{n}}$ and the wavelet $\psi_{0}$ at time $t$ and scale $s$, where $x_{\mathrm{n}}$ consists of a series of observations $x_{0}, \ldots, x_{N-1}$ spaced equally in time by $\delta_{\mathrm{t}}($ Johansson et al., 2009). As described in Johansson et al. (2009), this is defined as

$W_{\eta, S}=\sum_{\eta^{\prime}=0}^{N-1} x_{\eta^{\prime}} \psi^{*}\left(\frac{\delta_{t}\left(\mathrm{\eta}-\eta^{\prime}\right)}{s}\right)$,

where the parameter $\psi^{*}$ is the complex conjugate of the wavelet that is normalized by a factor of $\left(\delta_{t} / s\right)^{1 / 2}$ to ensure unit energy, and allowing comparability between scales and analyses. In order to adjust the time-frame to a more meaningful scale, the parameter $\delta_{\mathrm{t}}$ is included. Wavelet transformations are complex and describe time and frequency-specific power and phase. The strength of the wavelet-like behavior at every point is indicated by the power $\left|W_{n, s}\right|^{2}$, and is indicated in the power spectrum of each transformation. The angular position of each point in its cyclical trajectory is given by the phase $(\theta)$. It varies from a trough at $\pi$ radians to a peak at 0 or $2 \pi$ radians. 
Table 3.1: Raw variables used in the analysis.

\begin{tabular}{|c|c|c|c|c|c|c|c|}
\hline 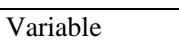 & Data description & Min & Max & Median & Mean & Standard Deviation & Data period \\
\hline \multicolumn{8}{|l|}{ Tourism demand } \\
\hline USATOUR & Tourism demand from the $\mathrm{NE}^{\mathrm{g}} \mathrm{USA}$ & 7425 & 603 & 32081 & 30894 & 13834 & $1981-2015^{\mathrm{ab}}$ \\
\hline VENTOUR & Tourism demand from Venezuela & 488 & 403 & 5524 & 7181 & 6499 & $1981-2015^{\mathrm{ab}}$ \\
\hline HOLTOUR & Tourism demand from Holland & 146 & 915 & 2693 & 2410 & 1146 & $1981-2015^{\mathrm{ab}}$ \\
\hline \multicolumn{8}{|l|}{ Weather } \\
\hline AUAWIND & Windspeed data Aruba $(\mathrm{m} / \mathrm{s})$ & 3.0 & 10.0 & 7.5 & 7.3 & 1.2 & $1981-2015^{\mathrm{ac}}$ \\
\hline AUARAIN & Rainfall data Aruba (mm) & 0.5 & 312 & 20.3 & 39.3 & 49.9 & $1981-2015^{\text {ac }}$ \\
\hline AUATEMP & Average temperature Aruba ${ }^{\circ} \mathrm{C}$ & 25.6 & 30.5 & 28.2 & 28.1 & 1.0 & $1981-2015^{\text {ac }}$ \\
\hline USAWIND & Windspeed data NEg USA $(\mathrm{m} / \mathrm{s})$ & 4.1 & 8.6 & 6.4 & 6.4 & 1.0 & $1981-2015^{\text {ad }}$ \\
\hline USARAIN & Rainfall data $\mathrm{NE}^{\mathrm{g}}$ USA (mm) & 1.1 & 197 & 75.0 & 72.3 & 37.8 & $1981-2015^{\text {ae }}$ \\
\hline USATEMP & Average temperature $\mathrm{NE}^{\mathrm{g}} \mathrm{USA}{ }^{0} \mathrm{C}$ & 2.9 & 32.3 & 19.3 & 19.3 & 8.5 & $1981-2015^{\text {af }}$ \\
\hline VENWIND & Windspeed data Venezuela $(\mathrm{m} / \mathrm{s})$ & 3.0 & 7.19 & 5.1 & 5.1 & 0.9 & $1981-2015^{\text {ad }}$ \\
\hline VENRAIN & Rainfall data Venezuela (mm) & 0.5 & 393 & 67.3 & 74.8 & 65.8 & $1981-2015^{\text {ae }}$ \\
\hline VENTEMP & Average temperature Venezuela ${ }^{0} \mathrm{C}$ & 23.5 & 29.3 & 25.3 & 25.6 & 1.2 & $1981-2015^{\text {af }}$ \\
\hline HOLWIND & Windspeed data Holland $(\mathrm{m} / \mathrm{s})$ & 2.6 & 13.8 & 8.0 & 8.0 & 2.9 & $1981-2015^{\text {ad }}$ \\
\hline HOLRAIN & Rainfall data Holland (mm) & 0.02 & 168 & 55.1 & 55.7 & 36.0 & $1981-2015^{\text {ae }}$ \\
\hline HOLTEMP & Average temperature Holland & 5.5 & 32. & 19.6 & 19.5 & 6.1 & $1981-2015^{\text {af }}$ \\
\hline
\end{tabular}

${ }^{\mathrm{a}}$ Through November $2015,{ }^{\mathrm{b}}$ Central Bank of Aruba, ${ }^{\mathrm{c}}$ Meteorological Department Aruba, ${ }^{\mathrm{d}}$ The European Centre for Medium-Range Weather Forecasts (ECMWF) ReAnalysis (ERA-Interim), ${ }^{\mathrm{e}}$ Global Precipitation Climatology Centre operated by Deutscher Wetterdienst and Climate Prediction Center Merged Analysis of

Precipitation, ${ }^{\mathrm{f}}$ National Centers for Environmental Prediction -National Center for Atmospheric Research (NCEP-NCAR) reanalysis (NCEP1) data,

${ }^{\mathrm{g}}$ Northeast 
The phase $(\theta)$ is calculated as the inverse tangent of the imaginary component of the transform divided by the real component (Johansson et al., 2009):

$$
\theta_{n, s}=\arctan \left(\frac{\Im\left(W_{n, s}\right)}{\Re\left(W_{n, s}\right)}\right)
$$

The wavelet can extend itself both forward and backward in time. Therefore the beginning and end of a time-series are effectively joined in a loop so that there is prior and post information at any point (Johansson et al., 2009). To avoid this, the authors pad the time-series with zeros to the next power of 2 of their length, in line with Torrence and Compo (1998). Since the zeros still influence the transformation at the extremities, the area of the transform is masked, where edge effects are significant (Johansson et al., 2009). Given that the Morlet wavelet is complex, it allows the quantification of the phase, and therefore, it can calculate time-lags between different timeseries. Coherence based on wavelets allows one to do similar analysis as crosscorrelation even for possible nonstationary signals (Do et al., 2014). In this study, wavelet coherence was calculated to examine the association between different time-series, both in time and frequency. Coherence spectra allow one to investigate whether different periodic modes of two time-series tend to oscillate concurrently, and, if they do, one can identify the periodicity around which this relationship takes place (Do et al., 2014). For this study, we calculated the squared coherency $\left(R^{2}\right)$,

$$
R_{n, S}^{2}=\frac{\mid S\left(\left.s^{-1} W_{n, S}^{X Y}\right|^{2}\right.}{S\left(s^{-1}\left|W_{n, S}^{X}\right|^{2} \mid\right) S\left(\left.s^{-1} W_{n, s}^{Y}\right|^{2}\right)},
$$

where $s^{-1}$ will normalize the energy, $\mathrm{W}^{\mathrm{x}}$ is one wavelet transform variable, $\mathrm{W}^{\mathrm{y}}$ is the other variable, $\mathrm{W}^{\mathrm{xy}}$ is the cross-wavelet spectrum $\left(\mathrm{W}^{\mathrm{x}} \mathrm{W}^{\mathrm{y}}\right)$, and $\mathrm{S}(\mathrm{W})$ is the sequential smoothing function $S_{\text {scale }}\left(S_{\text {time }}\right)$ following Johansson et al., (2009). The scale specific convolution of W with a normalized Gaussian filter is defined as $S_{\text {time. }} S_{\text {scale }}$ is the time-specific convolution of the result with a normalized boxcar filter (Johansson et al., 2009). As indicated by Johansson et 
al. (2009), the denominator of the power spectra is smoothed prior to finding the modulus and squaring. Significance levels were calculated using a Chisquare test assuming that the wavelet coefficients are normally distributed, in line with Torrence and Compo, (1998). The phase of the coherency can also be calculated. This will give one time and frequency-specific differences in phase between the two-time series (Johansson et al., 2009):

$\theta_{n, s}^{\text {diff }}=\arctan \left(\frac{\Im\left(s\left(s^{-1} W_{n, s}^{X Y}\right)\right)}{\Re\left(S\left(s^{-1} W_{n, S}^{X Y}\right)\right)}\right.$.

For a more in-depth description of the theory for wavelet analysis, please refer to Cazelles, Chavez, de Magny, Guégan, and Hales (2007), and Torrence and Compo (1998).

Before wavelet decomposition, the applied time-series were altered by a Box-Cox power transformation, in order to make the distribution values more symmetrical and induce a variance-stabilizing effect, following Wilks, (1995). As shown by Osborne (2010), Box-Cox power transformations were superior to traditional transformations, such as square root, log, and inverse. Hinkley's $\mathrm{d} \lambda$ statistic was used to find the best transformation parameter in line with Wilks (1995). Imputations for missing values were done in the Dutch tourism data through a Kalman filter, based on state-space methods, following Durbin and Koopman (2008). Loess smoother was also applied to the data to remove any trend similar to Cleveland (1979), Cleveland, McRae, and Terpenning (1990). The idea of a locally weighted regression, or loess, procedure, is fitting a regression surface data through multivariate smoothing. The dependent variable is smoothed as a function of the independent variables in a moving manner, analogous to how a moving average is calculated for a time series (Cleveland \& Devlin, 1988). All analyses were conducted in Microsoft Excel (2010) and R (Team, 2016). Wavelet analyses were performed using the "WaveletComp" R package (Roesch \& Schmidbauer, 2014). 


\subsection{Results and discussion}

Figure 3.2 A, B, C shows the wavelet power spectrum for tourism demand from USATOUR, VENTOUR, and HOLTOUR. High power will indicate the frequency and time-specific periodicity (Johansson et al., 2009). Since we are mainly interested in cyclic variations, we looked only between 12 to 256 months (>1 to 21 years). Since we were interested in non-seasonal data, we started from 12 months (>1 year). The period of 256 ( 21 years), was chosen as a maximum since most variables did not show any significant power passed this value.

The wavelet transform of USATOUR showed significant periodicity in the 3-6 years and 9 - 15 years, with peaks around 4 and 11.7 years. The highest peak was around four years. The wavelet transform of VENTOUR showed significant periodicity in the $2-4$ years and $6-21$ years, with peaks around 3 , 8.4 , and 18 years. The highest power was around 8.4 years. The wavelet transform of HOLTOUR showed significant periodicity near four years, between 6-9 years and 10 - 20 years. The highest peak was around 14 years, followed by the next peak of 7.2 years.

The wavelet transformation of AUARAIN showed significant periodicity in the $3-7$ years, with a high peak around 3.8 years and another peak at 5.7 years. The wavelet transformation of AUAWIND showed significant periodicity in the $3-8$ years and $9-13$ years. The peaks were at, respectively, 3.7, 5.6, and 10.7 years, where the peak around 5.6 was the highest. The wavelet transformation of AUATEMP showed no significant periodicity within the time-frame chosen. The wavelet transformation of USARAIN showed significant periodicity in the $3-4$ years, 5 - 13 years, and 14 - 19 years, peaks were around 3.3, 5.6, and the highest peak around 8.4 years. 


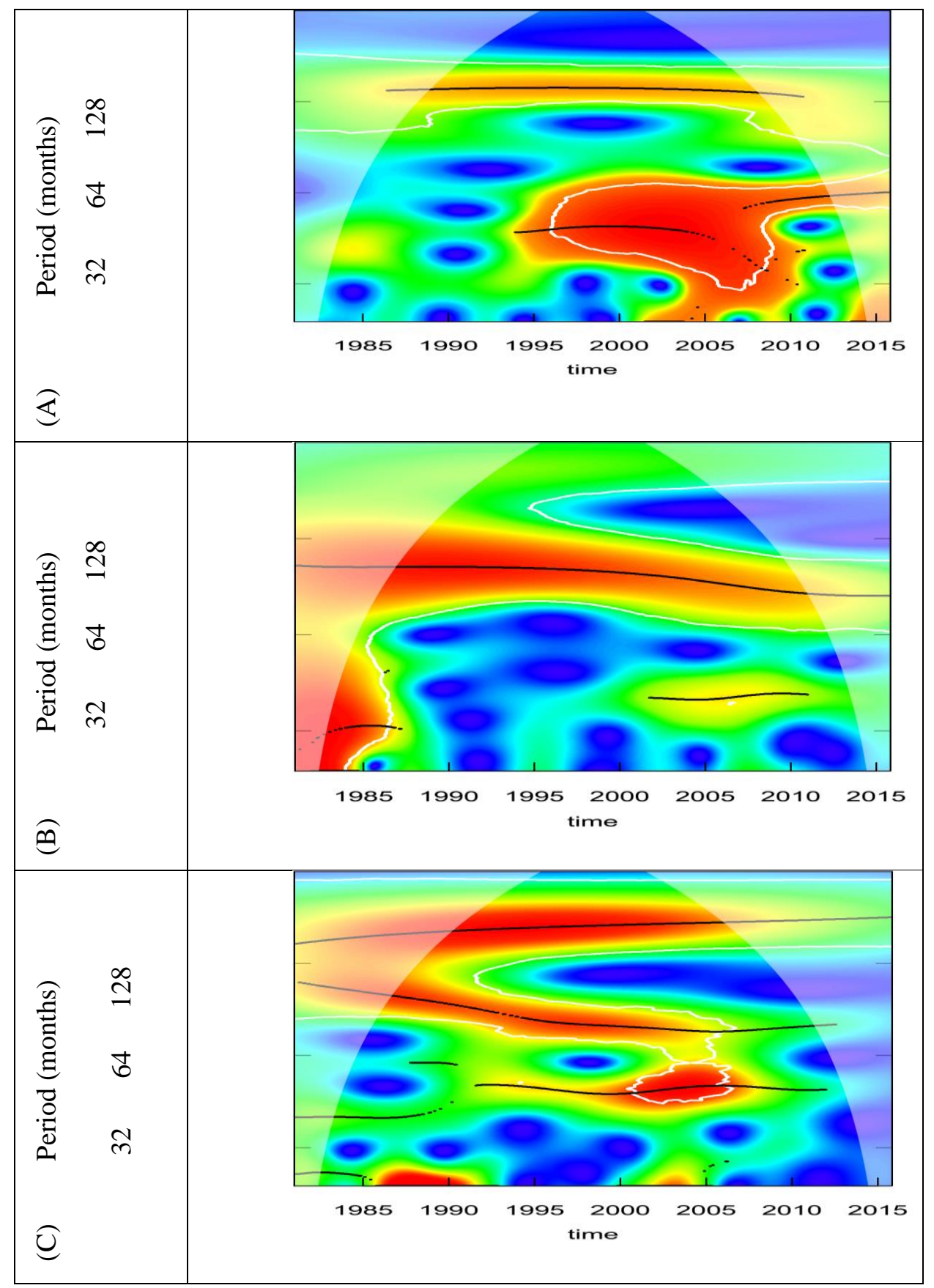

Figure 3.2: A) Wavelet Spectra USATOUR, B) Wavelet Spectra VENTOUR, C) Wavelet Spectra HOLTOUR. 
The wavelet transformation of USAWIND showed no significant periodicity within the time-frame chosen, whereas that of USATEMP showed no significant periodicity within the time-frame chosen. The wavelet transformation of VENRAIN showed significant periodicity in around $6-7$ years, 8 - 12 years, and 17 - 19 years. The peaks for VENRAIN were 5.9 and 9.8 years. The wavelet transformation of VENWIND showed significant periodicity around $6-8$ years, with a peak of around 6.4 years. The wavelet transformation of VENTEMP showed significant periodicity in the 3 - 4 years and 5 - 8 years. The peaks for VENTEMP were around 3.6 and 6.2 years. The wavelet transformation of HOLRAIN showed significant periodicity in around four years, between 5 - 9 years, and between $10-12$ years, with a peak of around 6.1 years. Both the wavelet transformation of HOLWIND and HOLTEMP showed no significant periodicity within the chosen time-frame.

In order to detect and quantify correlations between variables that showed significant periodicity, wavelet coherence was calculated according to Gallegati and Semmler (2014). For the wavelet coherences, only variables that showed significant periodicity between 24 to 256 months were used. Significant periods that had relationships are given in years. The data are based on wavelet coherence across time, of two time-series (Tian \& Cazelles, 2012; Cazelles et al., 2007).

Significant correlations were found for pull weather factors of rain and wind with tourism demand from the Northeast Sector of the United States and Holland. Both tourism demand sectors had relationships for around four years. Rain pull factor also correlated with tourism demand from the Northeast Sector of the United States between 10 - 11 years. The wind-speed on Aruba also had a relationship with the tourism demand from the Northeast Sector of the United States around five years and a relationship with tourism demand from Holland near two years and tourism demand from Venezuela around three years. 
For push weather variables, it was noted that wind-speed near Caracas had a relationship with tourism demand from Venezuela, near two years and between 7 - 8 years. Air temperature near Caracas also influenced tourism demand from Venezuela between 6 - 7 years.

Because some of these relationships in the cyclical patterns happened simultaneously at different locations, we decided to look into two main climate phenomena that can influence periodical weather patterns around the world. Climate does not influence populations through a single weather variable but a mix of weather features. Proxies for the overall climate condition can, at least at an early stage, provide a robust estimation of the ecological influences of climate fluctuations, not least because of the holistic account of the climate system (Stenseth et al., 2003). We used the El Niño Southern Oscillation (ENSO) and the North Atlantic Oscillation (NAO) since these were shown to be of great use by other areas of study (Stenseth et al., 2003). El Niño and La Niña compose the El Niño Southern Oscillation, which are periodic anomalies in sea surface temperatures (SSTs) in the equatorial Pacific Ocean. These warmer or cooler anomalies in ocean temperatures can influence weather patterns around the world by influencing high and low-pressure systems, winds, and precipitation (NOAA, 2016). To measure ENSO, we used the Multivariate ENSO Index (MEI) (NCAR, 2016). The North Atlantic Oscillation consists of a north-south dipole of anomalies, with one center placed over Greenland and the other of opposite sign spanning the central latitudes of the North Atlantic between 35 and 40 degrees north. The positive phase of the NAO mirrors below-normal heights and pressure across the high latitudes of the North Atlantic and above-normal heights and pressure over the central North Atlantic, the eastern United States, and Western Europe. The negative phase of NAO reflects the opposite. Both phases of the NAO are associated with changes in temperature and precipitation patterns, often 
extending from eastern North America to western and central Europe (CPC, 2016a).

The wavelet transformation of MEI showed peaks in periodicity around 2.6, 3.7, 5, and 11 years. The highest peak in periodicity for MEI was around 3.7 years. The wavelet transformation of NAO, showed peaks in periodicity around 2.5 , and 11.6 years. The highest peak in periodicity for NAO was around 2.5 years.

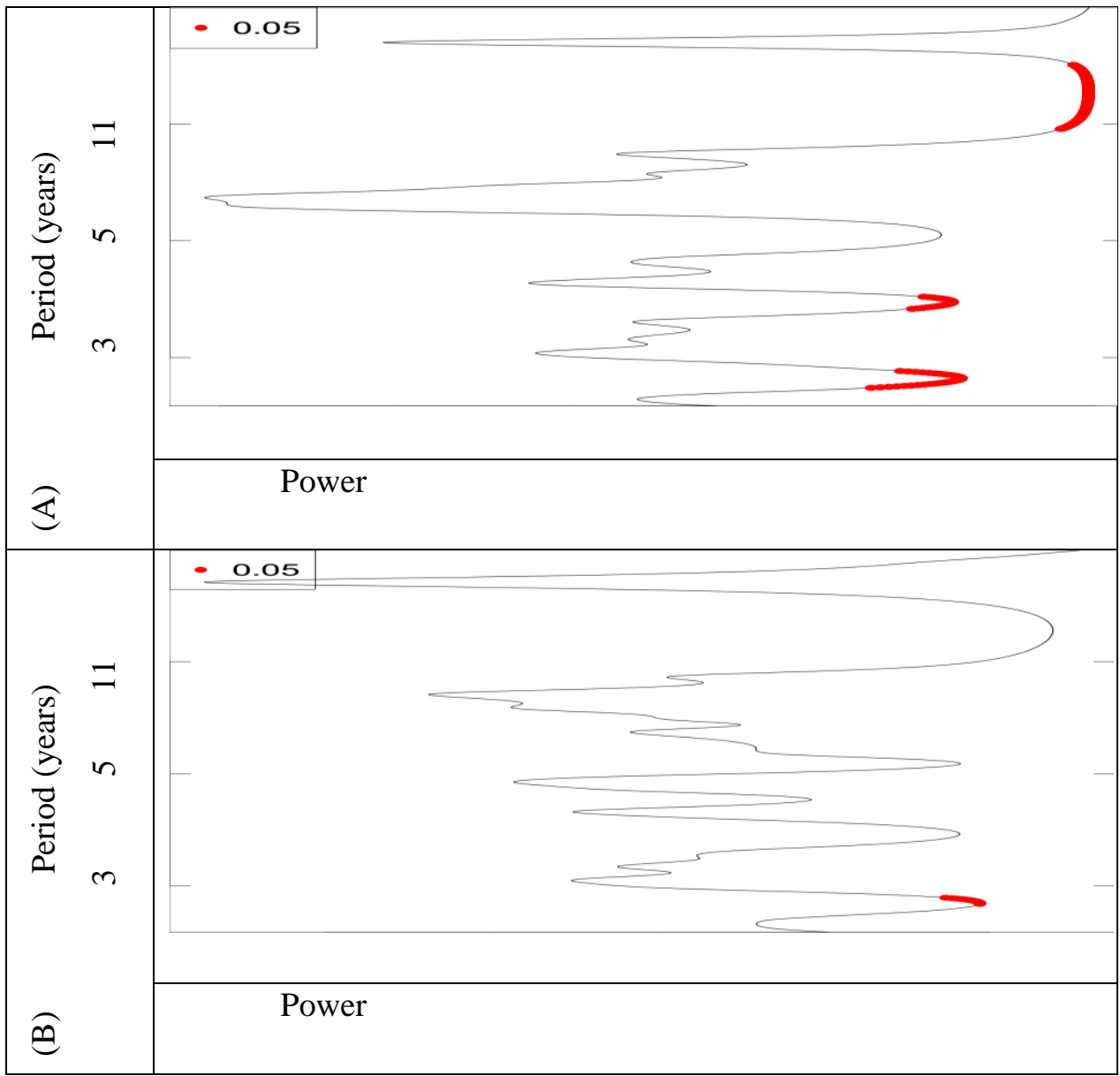

Figure 3.3: A) Average Wavelet Coherence Power USATOUR, MEI, B) Average Wavelet Coherence Power HOLTOUR, MEI. 
Following Johansson et al. (2009), the authors proceeded to calculate wavelet coherences between the relevant variables, and phase differences in order to find the relationship between the variables. The variable MEI showed significant coherence with USATOUR in the periods of 2-3 years, four years, and 10-15 years (Figure 3.3A). MEI also showed a significant coherence with the variable HOLTOUR in the period of 2 - 3 years (Figure 3.3B). For the North Atlantic Oscillation (NAO), we noticed a significant relationship around two years and 10-14 years concerning USATOUR (Figure 3.4A). For HOLTOUR, we did not find a relationship and for the VENTOUR a significant coherence was found around eight years (Figure 3.4B).

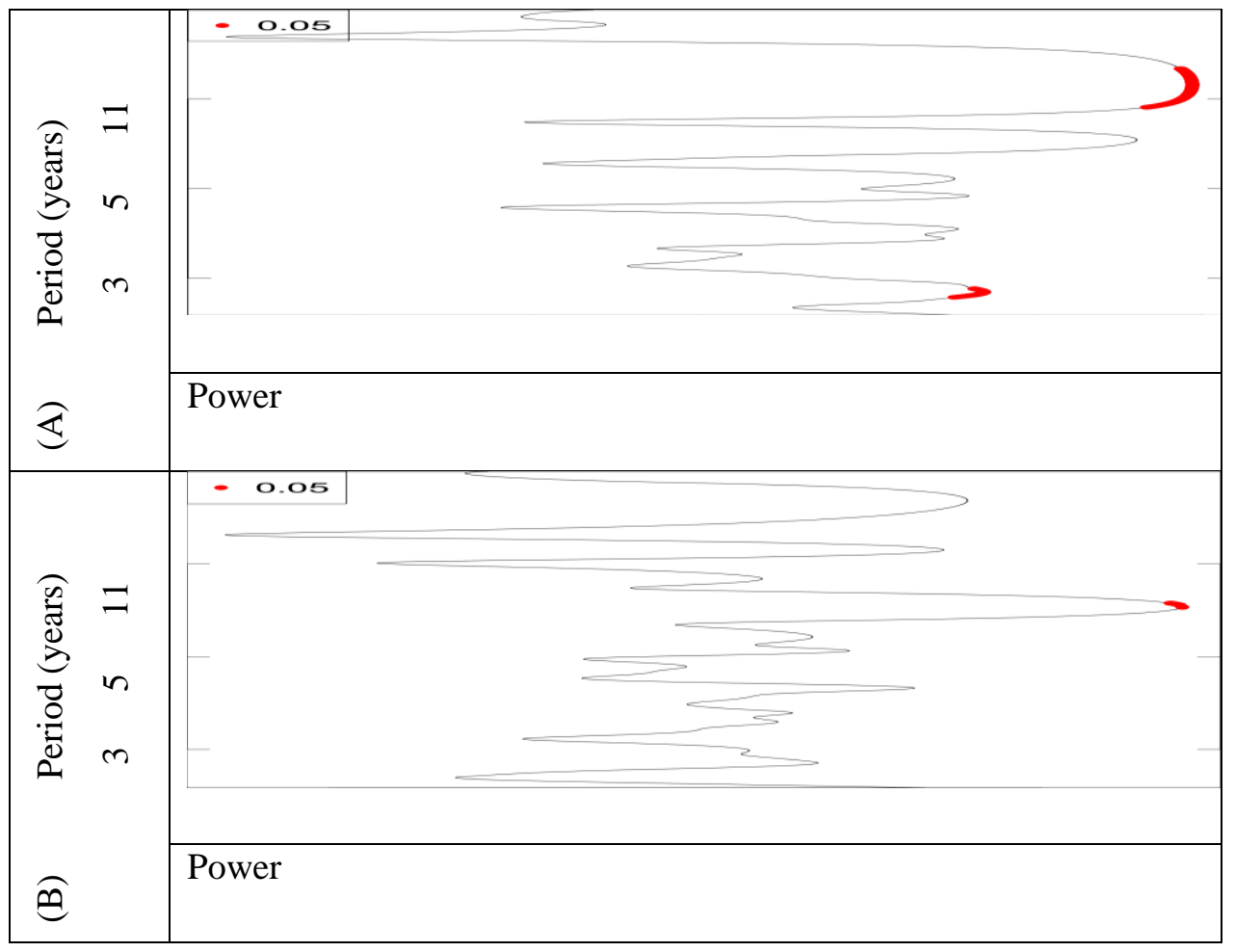

Figure 3.4: A) Average Wavelet Coherence Power USATOUR, NAO, B) Average Wavelet Coherence Power VENTOUR, NAO. 
Similar to Johansson et al. (2009), we can deduct from the phase difference calculations for the period between 2-3 years, and between the years 1986 and 1987, that increased ENSO leads tourism demand from the North East United States by six months (Figure 3.5A). The year 2016 is also a moderate ENSO year, according to the Climate Prediction Center (CPC, 2016b). The causality hints that El Niño events that oscillate between 2-3 years would act as a pull factor for tourists from the North-East sector of the United States. The period of 4 years showed small areas of wavelet coherence, and therefore they are unlikely to be causal, taken on their own (Keener et al., 2010). According to Keener, et al. (2010) more extensive areas of significance, are less likely to be due to chance and should be included in the analysis for additional relationships to a physical mechanism. For the period of $10-15$ years, it looked like causality by chance. This is because the phase difference analysis varied in the period, from MEI (ENSO) leading tourism demand from to North Eastern United States to tourism demand leading MEI (ENSO). Since this would be contradictory, we dropped the coherence in a period of 10 to 15 years as coherence by chance. The fluctuation of the signal in the same period would also be useless for forecasting purposes.

The phase difference for the period between 2 - 3 years and between 2007 and 2009 showed that a decrease in ENSO leads to an increase in tourism demand from the Netherlands (Figure 3.5B). This hints that a La Niña episode would cause an increase in Dutch tourists eventually.

ENSO will usually influence weather patterns, and therefore, we would expect that some of the weather pull or push factors could have, also, an influence. Calculations showed that AUARAIN would influence USATOUR and HOLTOUR. 


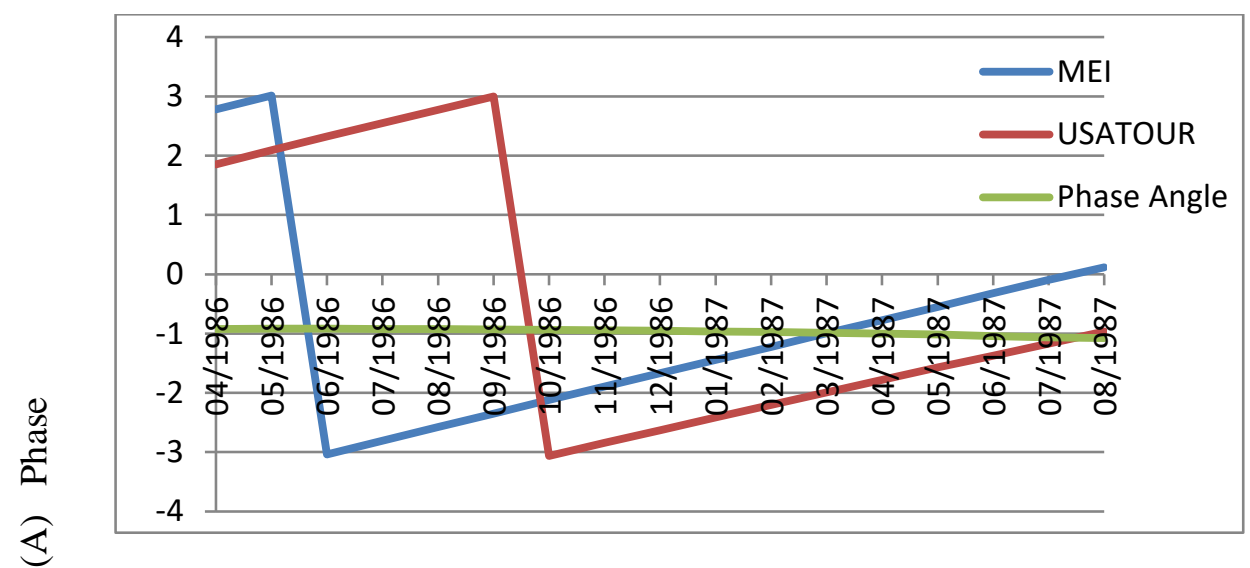

Time

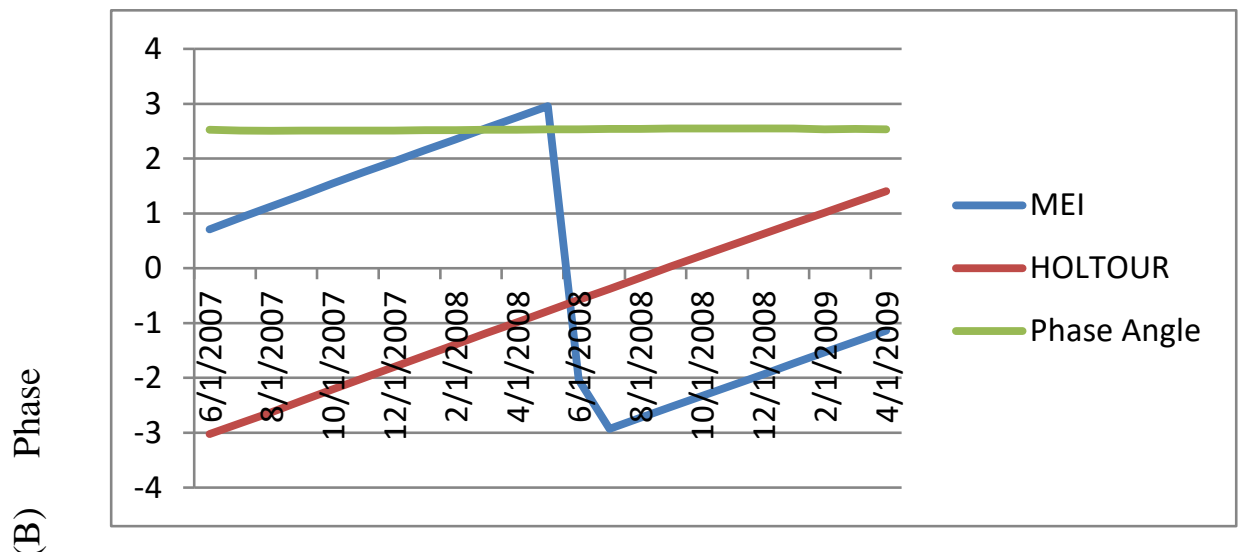

Time

Figure 3.5: A) Phase Angle USATOUR, MEI (ENSO) (1986-1987), B) Phase Angle HOLTOUR, MEI (ENSO) (2007-2009).

Past literature showed that rain increases during La Nina events while rain decrease during El Nino events on Aruba (Martis, van Oldenborgh, \& Burgers, 2002). This would indicate that USATOUR would increase during fewer rain events on Aruba, while HOLTOUR would increase during more rain events on Aruba. Previous research has shown that strong El Nino's could increase rain in the Netherlands during spring and that La Nina had no influence on the rain 
pattern on Holland (van Oldenborgh, Burgers, \& Tank, 2000). This would indicate that a La Nina event would not act as a push factor on tourism demand from Holland, but more like a pull factor from Aruba. Although at first sight, it would not be logical that more rainfall would attract a tourist to a destination, the authors believe that maybe a more detailed study needs to be conducted on the travel perception of the Dutch tourist. Maybe the Dutch tourist would prefer a destination with more vegetation, compared to a drought-stricken destination. Another caveat could be those other destinations that the Dutch tourist would have chosen over Aruba, were more heavily influenced by un-attractive climate conditions due to La Nina compared to Aruba. Finally, the relationship could indicate that the heavy tourism marketing of Aruba could have influenced the Dutch tourist to choose Aruba, even during anomalous rainfall periods.

For NAO, we noticed a significant relationship around two years, and 10-14 years for USATOUR and around eight years for the VENTOUR. The phase difference for USATOUR for the period around two years between 1981-1982 and 1990-1991 showed that an increase in USATOUR would be related to a decrease in NAO, where USATOUR leads NAO (Figure 3.6A). The phase periods for other years, within the two years, were dropped due to their short periods of length. The phase difference for USATOUR for the period between 10 - 14 years indicated that for the period from 1992-2015, NAO, and USATOUR would be in the phase were NAO would lead USATOUR (Figure 3.6B). The relationship between NAO and USATOUR for the short period of 2 years indicates that temperature could be a culprit since, during negative phases of NAO, the eastern part of the USA is colder and drier (Stenseth et al., 2003). 


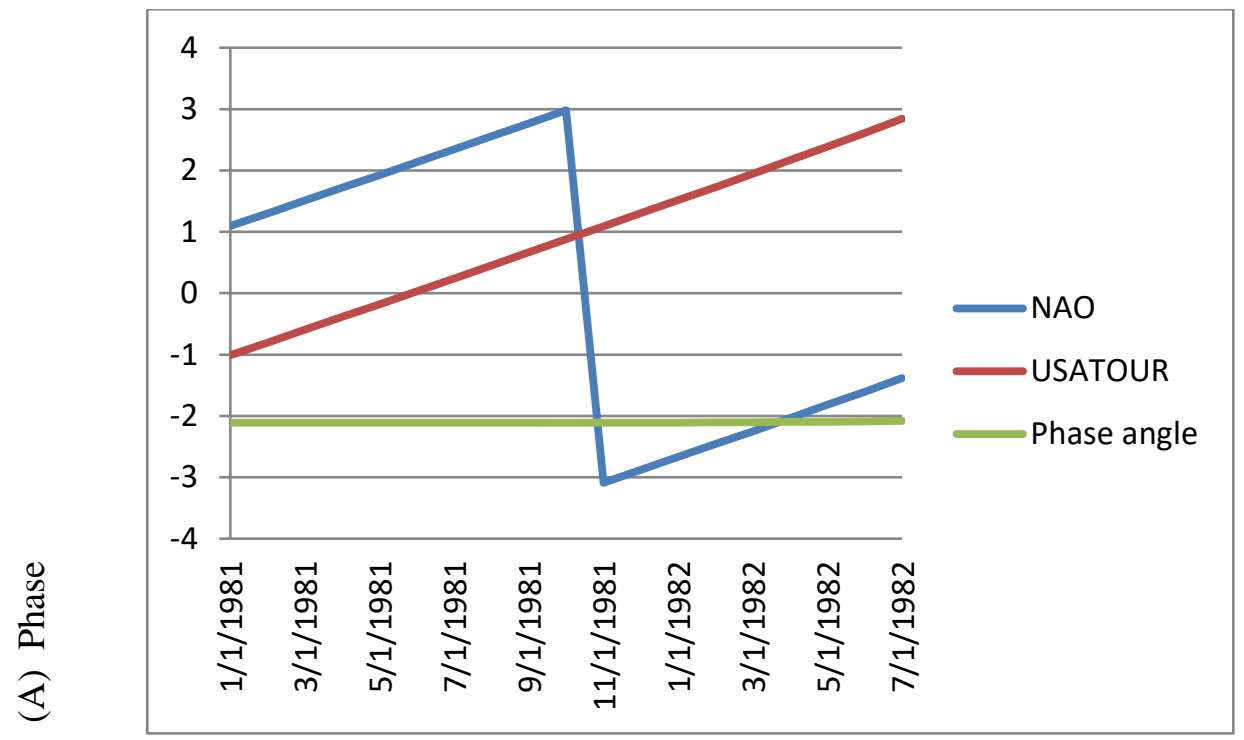

Time

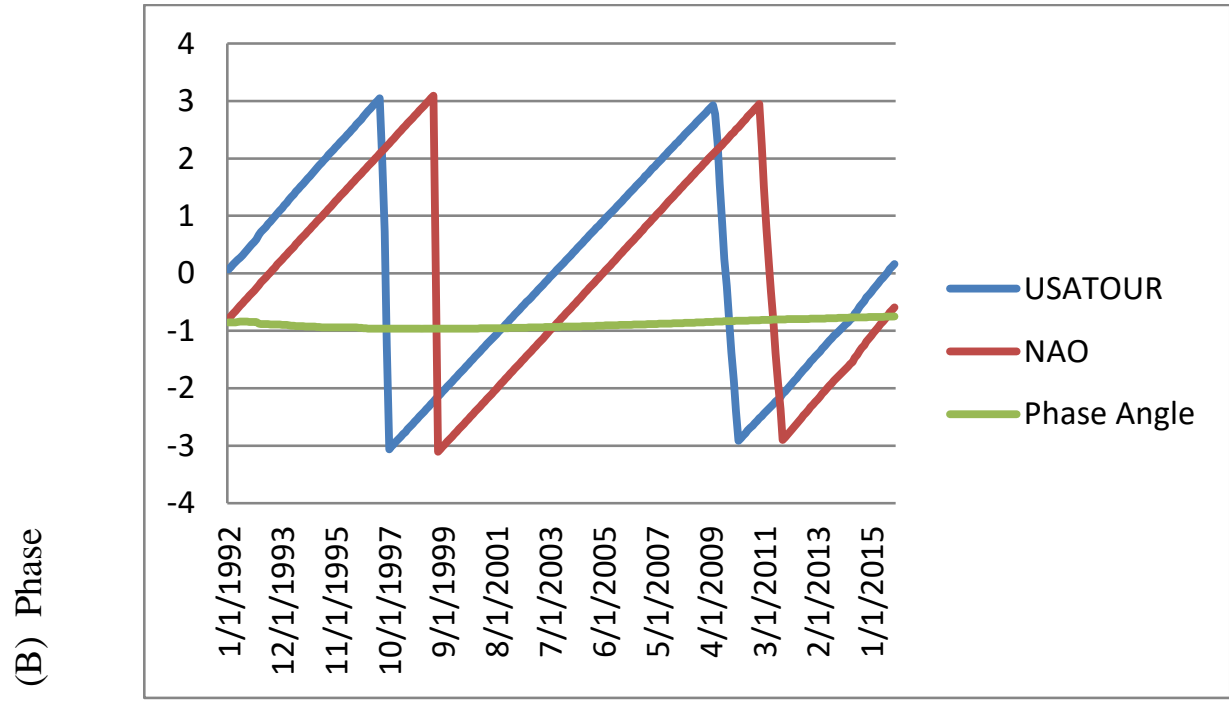

Time

Figure 3.6: A) Phase Angle USATOUR, NAO (1981-1982), B) Phase Angle USATOUR, NAO (1992-2015). 
Since the authors did not find any relationship between long-time ${ }^{12}$ temperature deviations and long-time deviations from tourism demand from the Northeast sector and the relationship between drier weather conditions and more tourism demand from the northeast sector of the USA is not logical, they dropped the relationship between the NAO and USATOUR for two years. The relationship between USATOUR and NAO for the $10-14$ years indicated that positive phases of NAO would lead to an increase in tourism demand from the Northeast sector. Positive phases of NAO usually relate to wetter and warmer conditions in the eastern USA (Stenseth et al., 2003). In the current study, the authors did not find any relationships with USARAIN and USATOUR. Therefore, precipitation cannot be considered as a push factor. Since the authors did not find any relationships with temperature, they did not consider temperature as a significant push factor, too. It is also not logical that a warmer temperature at a location would induce a tourist to go to an even warmer destination. The wind could, also, not act as a push factor since no coherence was found between USAWIND and USATOUR. During favorable NAO conditions, one would expect drier and breezy conditions on Aruba, due to a stronger than average Atlantic surface pressure and stronger upwelling near Aruba (Giannini, Cane, \& Kushnir, 2001; Lahey, 1958). These conditions would corroborate earlier findings on the Aruban wind and rain relationship and tourism from the United States. This would suggest that wind and rain conditions on Aruba would act as a pull factor, and explain the relationship between positive NAO anomalies and tourism from the United States.

The phase difference for VENTOUR and NAO for the period around eight years indicated that for the period from 1991-1985 and 2012-2015,

\footnotetext{
12 The author uses long-time implace of long-term in order to avoid confusion between trend and time component. Long-time referns a time component.
} 
VENTOUR and NAO would be in the phase were NAO would lead VENTOUR. This pattern indicates that the positive values of NAO would cause Venezuelans to travel to Aruba. Since any effect of a positive phase of NAO would be the same for Aruba as for Venezuela, the authors dropped this relationship. Past literature shows that favorable NAO conditions would relate to drier Caribbean, including the northern part of Venezuela, due to subsidence and sea surface temperature anomalies (Giannini et al., 2001). These manifests themselves due to a stronger than average Atlantic high-pressure area.

\subsection{Conclusion}

This study suggests that tourism is connected to cyclical climate movements. Past literature showed that tourism literature had paid not much attention to the effects of meteorological factors to explain tourism flow, and a vast majority of the international tourism-demand models do not contain climate and weather conditions as explanatory variables (Álvarez-Díaz et al., 2010). The main objective of this study was to underline that cyclical climate factors matter in tourism and that they should be taken into account. The authors specifically investigated the existence of a statistical relationship between 3 main push and pull climate variables (rain, temperature, and wind) and tourism demand from many markets, namely the USA, the Netherlands, and Venezuela. They further looked into the climate factors, by incorporating two essential modes of atmospheric variability, the NAO and ENSO, and investigated their possible relationships with tourism demand from the three markets. Results indicated that rain would act as a pull factor for the North-Eastern USA, and the Netherlands; the wind would act as a pull factor for the North-Eastern USA, the Netherlands, and Venezuela. We further noticed that ENSO events influenced the tourism demand from the United States and the Netherlands. The NAO also influenced the tourism demand from the United States. The present study adds 
some important contributions to the existing literature on tourism and climate on small island states, especially related to the two atmospheric variables:

1. Although some previous studies had already examined the influence of NAO and tourism, and ENSO influences on energy, agriculture and transport activities, it is to our knowledge, the first time that the effects of ENSO and NAO themselves on tourism have been looked for small island states, whereby several tourism markets were combined. The study by Álvarez-Díaz et al. (2010), focused more on a developed country (Spain).

2. The results of this study indicate that two important atmospheric variabilities, the NAO and ENSO, influence tourism demand from the USA, the Netherlands. The influences manifest themselves in a possible push and pull climate factors.

3. The results imply that an NAO or ENSO index can be useful to tourism in general. When constructing a possible tourism demand model, the NAO or an ENSO index as the MEI can be used as explanatory variables to tourism demand. According to Álvarez-Díaz et al. (2010), one can get parsimonious models since one can introduce into a model meteorological pieces of information using fewer variables.

4. According to Álvarez-Díaz et al. (2010), meteorological data summarized in, for example, an NAO index can be useful in the operational decisionmaking process and risk management of a business in the tourism sector. The same idea can be implemented when considering an ENSO index such as MEI.

The results also have managerial implications. Policymakers and other key decision-makers need to understand the combined influence of cyclical oscillations of push and pull climate elements on oscillations of tourism demand. According to Hamilton and Lau (2004), the climate is conceivably the third-most important trait in tourists' decision-making process after the aquatic and natural attributes of a destination. This study shows that monitoring 
economic factors alone is not enough when it comes to analyzing the determinants of tourism demand for Aruba. Climate patterns have an influence on travelers from the Netherlands, the USA, and Venezuela to Aruba. Knowledge about the structure of the climate variations could assist tourism managers and government representatives to (better) cope with long-time demand fluctuations in their planning, forecasting, and marketing efforts. For example, one possible strategy that policymakers and tourism leaders could follow would be to keep an eye on longer-time climate forecasts, for ENSO conditions such as that of the International Research Institute for Climate and Society (http://iri.columbia.edu/our-expertise/climate/forecasts/enso/current/) in order to get a lead on expected cyclical climate conditions such as ENSO and oscillation in tourism demand from the North-Eastern USA and the Netherlands. For instance, if an El Niño event is foreseen, than the likelihood of higher tourism demand from the North-Eastern USA increases, while the tourism demand from the Netherlands decreases. Policymakers and tourism chiefs in Aruba could react to this information, increasing marketing efforts for the Netherlands while decreasing marketing efforts for the North-Eastern USA, thereby compensating for the expected fall-down in demand from the Netherlands.

Finally, despite the promising results, the present study was limited to only 30 years of tourism demand for only the island of Aruba. It is recommended to add other destinations in the Caribbean and find destinations that have more extended tourism demand data to give further insight into the relationships found. Also, as indicated by Álvarez-Díaz et al. (2010), studies such as this one represent only a first step that opens a new line of research possibilities. Further research will be needed in order to construct a tourismdemand model that includes the NAO index as an explanatory variable to quantify further and explain the impacts of NAO on tourism. Our study hints that an ENSO index should also be included in such a tourism-demand model. 


\section{References}

Agnew, M. D., \& Palutikof, J. P. (2006). Impacts of short-term climate variability in the UK on demand for domestic and international tourism. Climate Research, 31(1), 109-120.

Álvarez-Díaz, M., Giráldez, M. S. O., \& González-Gómez, M. (2010).

Statistical relationships between the North Atlantic Oscillation and international tourism demand in the Balearic Islands, Spain. Climate Research, 43(3), 207-214.

Amelung, B., Nicholls, S., \& Viner, D. (2007). Implications of global climate change for tourism flows and seasonality. Journal of Travel research, 45(3), 285-296.

Apostolopoulos, Y. (1996). Introduction: reinventing the sociology of tourism. The sociology of tourism: Theoretical and empirical investigations. $1-14$.

Belén Gómez Martín, M. (2005). Weather, Climate and Tourism, A Geographical Perspective. Annals of Tourism Research, 571-591.

Burroughs, W. J. (2003). Weather cycles: real or imaginary? Cambridge: University Press.

Çaliskan, T., \& Kelkit, A. (2008). Climate Comfortable for Tourism: A Case Study of Canakkale. BALWOIS 2008. Macedonia:

http://balwois.com/conference/balwois-2004/.

Cazelles, B., Chavez, M., Magny, G. C. D., Guégan, J. F., \& Hales, S. (2007). Time-dependent spectral analysis of epidemiological time-series with wavelets. Journal of the Royal Society Interface, 4(15), 625-636.

Central Bureau Statistic. (2016, 06 01). Central Bureau of Statistics Aruba. Retrieved June 01, 2016, from Key Figures:

http://cbs.aw/wp/index.php/2015/09/14/key-figures/.

Cleveland, R. B., Cleveland, W. S., McRae, J. E., \& Terpenning, I. (1990). STL: A seasonal-trend decomposition procedure based on loess. Journal of Official Statistics, 6(1), 3-73.

Cleveland, W. (1979). Robust locally weighted regression and smoothing scatterplots. Journal of the American statistical association, 74(368), 829-836.

Cleveland, W., \& Devlin, S. (1988). Locally weighted regression: an approach to regression analysis by local fitting. Journal of the American statistical association, 83(403), 596-610.

CPC, (2016a). North Atlantic Oscillation (NAO). Retrieved 2016, from North Atlantic Oscillation (NAO):

http://www.cpc.ncep.noaa.gov/data/teledoc/nao.shtml.

CPC, (2016b). Historical El Nino/ La Nina episodes (1950-present). Retrieved

4 14, 2016, from Historical El Nino/ La Nina episodes (1950-present):

http://www.cpc.ncep.noaa.gov/products/analysis_monitoring/ensostuff/ ensoyears.shtml. 
Croes, R. (2006). A Paradigm Shift to a New Strategy for Small Island Economies: Embracing Demand Side Economics for Value Enhancement and Long Term Economic Stability. Tourism Management, 453-465.

Cuccia, T., \& Rizzo, I. (2011). Tourism seasonality in cultural destinations: Empirical evidence from Sicily. Tourism management, 32(3), 589-595.

Do, T. T. T., Martens, P., Luu, N. H., Wright, P., \& Choisy, M. (2014). Climatic-driven seasonality of emerging dengue fever in Hanoi, Vietnam. BMC public health, 14(1), 1078.

Durbin, J., \& Koopman, S. (2008). Time Series Analysis by State Space Methods. Oxford: Oxford University Press.

Eisenhardt, K., \& Graebner, M. (2007). Theory Building from Cases: Opportunities and Challenges. Academy of Management Journal, 2532.

Gallegati, M., \& Semmler, W. (2014). Wavelet applications in economics and finance. New York: Springer.

Geda, A. (2015). Applied Time Series Econometrics: a practical guide for macroeconomic researchers with a focus on Africa. University of Nairobi Press.

Geer, I. W. (1996). Glossary of weather and climate with related oceanic and hydrologic terms. Collection Atmosphere.

Giannini, A., Cane, M. A., \& Kushnir, Y. (2001). Interdecadal changes in the ENSO teleconnection to the Caribbean region and the North Atlantic Oscillation. Journal of Climate, 14(13), 2867-2879.

Goeldner, C. R., \& Ritchie, J. B. (2012). Tourism, Principles, Practices, Philosophies. John Wiley \& Sons.

Gouveia, P. M., \& Rodrigues, P. M. (2005). Dating and synchronizing tourism growth cycles. Tourism Economics, 11(4), 501-515.

Grinsted, A., Moore, J. C., \& Jevrejeva, S. (2004). Application of the cross wavelet transform and wavelet coherence to geophysical time series.

Guizzardi, A., \& Mazzocchi, M. (2010). Tourism demand for Italy and the business cycle. Tourism Management, 31(3), 367-377.

Hamilton, J., \& Lau, M. (2004). The Role of Climate Information in Tourist Destination Choice. Working Paper FNU-56.

Hamilton, J. M., \& Tol, R. S. (2007). The impact of climate change on tourism in Germany, the UK and Ireland: a simulation study. Regional Environmental Change, 7(3), 161-172.

Hamilton, J. M., Maddison, D. J., \& Tol, R. S. (2005). Climate change and international tourism: a simulation study. Global environmental change, 15(3), 253-266.

Johansson, M. A., Cummings, D. A., \& Glass, G. E. (2009). Multiyear climate variability and dengue - El Nino southern oscillation, weather, and dengue incidence in Puerto Rico, Mexico, and Thailand: a longitudinal data analysis. PLoS medicine, 6(11). 
Karamustafa, K., \& Ulama, S. (2010). Measuring the Seasonality in Tourism With the Comparison of Different Methods. Euromed Journal of Business, 191-214.

Keener, V. W., Feyereisen, G. W., Lall, U., Jones, J. W., Bosch, D. D., \& Lowrance, R. (2010). El-Niño/Southern Oscillation (ENSO) influences on monthly NO3 load and concentration, stream flow and precipitation in the Little River Watershed, Tifton, Georgia (GA). Journal of hydrology, 381(3-4), 352-363.

Kožić, I. (2014). Detecting international tourism demand growth cycles. Current Issues in Tourism. 17(5), 397-403.

Lahey, J. (1958). On the Origin of the dry climate in the Northern South America and the Southern Caribbean. University of Wisconsin Department of Meteorology Scientific Report.

Lau, K. M., \& Weng, H. (1995). Climate signal detection using wavelet transform: How to make a time series sing. Bulletin of the American meteorological society, 76(12), 2391-2402.

Lundberg, D. E., Krishnamoorthy, M., \& Stavenga, M. H. (1995). Tourism economics. John Wiley and sons.

Matzarakis, A. (2006). Weather-and climate-related information for tourism. Tourism and Hospitality Planning \& Development, 3(2), 99-115.

Martis, A., van Oldenborgh, G. J., \& Burgers, G. (2002). Predicting rainfall in the Dutch Caribbean - more than El Nino?. International Journal of Climatology: A Journal of the Royal Meteorological Society, 22(10), 1219-1234.

Moreno, A., Amelung, B., \& Santamarta, L. (2008). Linking beach recreation to weather conditions: a case study in Zandvoort, Netherlands. Tourism in Marine Environments, 5(2-3), 111-119.

NCAR (2016). Multivariate ENSO Index. Retrieved 2016, from Multivariate ENSO Index:

https://climatedataguide.ucar.edu/climate-data/multivariate-enso-index.

NOAA (2016). El Niño Southern Oscillation (ENSO). Retrieved 2016, from El Niño Southern Oscillation (ENSO):

http://www.esrl.noaa.gov/psd/enso/.

Oduber, M., Ridderstaat, J., \& Martens, P. (2015). The connection of vegetation with tourism development and economic growth: A case study for Aruba. Journal of Environmental Science and Engineering, 4, 420-431.

Osborne, J. (2010). Improving your data transformations: Applying the BoxCox transformation. Practical Assessment, Research, and Evaluation, 15(1), 12.

Pegg, S., Patterson, I., \& Gariddo, P. V. (2012). The impact of seasonality on tourism and hospitality operations in the alpine region of New South Wales, Australia. International Journal of Hospitality Management, 31(3), 659-666. 
Ridderstaat, J. (2007). The Lago story: The compelling story of an oil company on the island of Aruba. Oranjestad: Editorial Charuba.

Ridderstaat, J., \& Croes, R. (2017). The link between money supply and tourism demand cycles: A case study of two Caribbean destinations. Journal of Travel Research, 56(2), 187-205.

Ridderstaat, J., Oduber, M., Croes, R., Nijkamp, P., \& Martens, P. (2014). Impacts of seasonal patterns of climate on recurrent fluctuations in tourism demand: Evidence from Aruba. Tourism Management, 41, 245-256.

Roesch A, \& Schmidbauer, H. (2014). WaveletComp: Computational Wavelet Analysis. $R$ package version 1.0. Retrieved from http://www.hsstat.com/projects/WaveletComp/WaveletComp_guided_ our.pdf.

Rua, A. (2012). Wavelets in economics. Economic Bulletin and Financial Stability Report Articles, 8.

Salish, N., \& Rodrigues, P. M. (2011). Panel seasonal unit root tests: An application to tourism. In Tourism Economics (pp. 183-210). PhysicaVerlag HD.

Schubert, S. F., \& Brida, J. G. (2011). Dynamic model of economic growth in a small tourism driven economy. In Tourism Economics (pp. 149-168). Physica-Verlag HD.

Scott, D., McBoyle, G., \& Schwartzentruber, M. (2004). Climate change and the distribution of climatic resources for tourism in North America. Climate research, 27(2), 105-117.

Stenseth, N. C., Ottersen, G., Hurrell, J. W., Mysterud, A., Lima, M., Chan, K. S., ... \& Ådlandsvik, B. (2003). Studying climate effects on ecology through the use of climate indices: the North Atlantic Oscillation, El Nino Southern Oscillation and beyond. Proceedings of the Royal Society of London. Series B: Biological Sciences, 270(1529), 20872096.

Team, R. C. (2016). R: A language and environment for statistical. Retrieved from R Foundation for Statistical Computing: http://www.R-project.org/.

Thacker, N., Mejia, S. A., \& Perrelli, R. (2012). Caribbean Growth in an International Perspective. Caribbean Growth in an International Perspective: The Role of Tourism and Size, 12(235), 1-34.

Tian, H., \& Cazelles, B. (2012). WaveletCo. Retrieved from http://cran.rproject.org/src/contrib/Archive/WaveletCo/.

Torrence, C., \& Compo, G. P. (1998). A practical guide to wavelet analysis. Bulletin of the American Meteorological society, 79(1), 61-78.

UNWTO \& UNEP. (2008). Climate Change and Tourism, Responding to Global Challenges. 
Van Oldenborgh, G. J., Burgers, G., \& Tank, A. K. (2000). On the El Niño teleconnection to spring precipitation in Europe. International Journal of Climatology: A Journal of the Royal Meteorological Society, 20(5), 565-574.

Vanhove, N. (2005). The Economics of Tourism Destinations. Elsevier Inc.

Wilks, D. S. (1995). Statistical methods in the atmospheric sciences. Academic Press.

Yin, R. (2009). Case Study Research, Design and Methods. Sage Publications, Inc. 

Part II:

Infectious Disease 


\title{
4. The Bilateral Relationship Between Tourism and Dengue
}

Occurrence. Evidence from Aruba ${ }^{I}$

\begin{abstract}
This study estimates the bilateral effects between seasonal patterns of dengue incidences and the recurring fluctuations of both stay-over tourism and cruise tourism. Seasonal patterns were first isolated from the series using the Census $\mathrm{X}-12$ decomposition method, after which the analysis included panel data unit root testing, panel data regression, and Mahalanobis distance calculation. The results show that cruise tourism increases dengue cases in Aruba, while dengue cases themselves had no influence on the number of stay-over and cruise visitors in Aruba. The study hints for an economical duality in cruise tourism in Aruba: (1) On one hand, cruise tourists who arrive at the harbor contribute to the economy of Aruba due to their spending activities; and (2) On the other hand, cruise tourists can induce costs by increasing the risk of spreading dengue. The Mahalanobis distance showed that the sensitivity of dengue cases to cruise tourism was the strongest during February, April-July, October, and November.
\end{abstract}

Keywords: seasonality, dengue, tourism demand, panel data, small island, Aruba

1. This chapter is based on Oduber, M., Ridderstaat, J., \& Martens, P. (2014). The Bilateral Relationship Between Tourism and Dengue Occurrence: Evidence from Aruba. Journal of Tourism and Hospitality Management, 2(6), 223-244. 


\subsection{Introduction}

Dengue is the most important viral vector-borne disease and an increasing problem globally (Gratz \& Knudsen, 1996). The disease is caused by four related yet distinct types of viruses transmitted by Aedes mosquitoes, which are very sensitive to environmental settings (Gubler \& Kuno, 1997). The mosquito bite can induce dengue fever, dengue hemorrhagic fever, and dengue hemorrhagic shock, which can all be deadly (Chakraborty, 2008). The economic impact of dengue fever or dengue hemorrhagic fever can be enormous, placing significant burdens on affected communities. This impact varies and can include: loss of life; medical expenditures, among others, for hospitalization of patients; loss in productivity of the affected workforce; strain on health care services due to sudden, high demand during an epidemic; considerable expenditures for large-scale emergency control actions; and loss of tourism as a result of negative publicity (Meltzer, Rigau-Perez, Clark, Reiter, \& Gubler, 1998). It is estimated that almost 50 million people travel annually from developed countries to tropical and third world countries, where morbidity to tropical countries carries a high risk (Stienlauf, Segal, Sidi, \& Schwartz, 2005). As more countries develop their tourism industry, it induces significant impacts on natural resources, consumption patterns, pollution, and social systems. The need for sustainable or responsible planning and management is necessary for the industry to survive as a whole. Several studies show that dengue can influence tourism (e.g., Cobelens et al., 2002; Wichmann, Muhlberger, \& Jelinek, 2003; Schwartz et al., 2008). For example, Cobelens et al. (2002) studied the incidence of dengue virus infections in a group of Dutch travelers to Asia and observed that dengue infections were frequent in travelers to endemic areas in Asia. Schwartz et al. (2008) studied seasonality and annual trends for dengue cases among returned travelers. They showed that dengue cases exhibit region-specific peaks, where travel-related dengue had annual oscillations and recommended that pre-travel advice should 
include information on relative risks of dengue infection according to season. Most of these studies looked at travelers acquiring the virus at a destination or the risk of infection and returning with the virus back home, but to our knowledge, there is a certain lack of studies exploring how dengue influences seasonal patterns of international tourism demand to Small Island Developing States. Principals of sustainability refer to the environmental, economic, and socio-cultural aspects of tourism development, where an appropriate balance must be made among these three dimensions to guarantee its long-term sustainability (United Nations Environment Program [UNEP], 2005). This stresses the case for a better understanding of the elements of tourism flow in small island economies. Croes (2006) indicated that many small islands use tourism development as a growth strategy for greater economic and development performance. Thacker, Acevedo, and Perrelli (2012) showed that the positive contribution from specializing in tourism has helped to offset the negative impact of being a small island economy, and according to the authors, tourism has been a significant provider to lower output volatility in many countries.

The purpose of this paper is to address the bilateral relationship between the seasonal time series of tourism demand and dengue incidence for a small island state. This involves analyzing, for the small island state of Aruba, the seasonal variations from tourism demand, namely, cruise tourism and stay-over tourism, the seasonal variations incidences of dengue cases reported, and the seasonal variations of climatic variables, namely, surface temperature, average maximum and minimum temperatures, rainfall, relative humidity, cloud incidences, and wind speed. The methodology involves the decomposition of time series on cruise tourism, stay-over tourism, dengue incidence, and several climate elements using Census X-12 decomposition procedure, and subsequent application of panel unit root test, panel regression, and the Mahalanobis distance calculation. The observed studies presented earlier, although 
suggestive, were often inadequate to provide how dengue influences seasonal patterns of tourism demand in small island destinations. Therefore, there is a case for a better understanding of the drivers of tourism demand in small island economies. Our study accesses Aruba as the case of interest. Yin (2009) indicated possible contributions of individual case studies to scientific generalizations through replication, where the mode is an analytic generalization. The idea is then to expand and generalize theories, and not to enumerate frequencies (statistical generalizations). Authors such as Eisenhardt and Graebner (2007) stated that building theory from case studies is a research strategy that requires as minimum one case to create theoretical constructs, propositions, and/or mid-range theory from case-based empirical evidence.

The rest of this paper is organized as follows. Section 4.2 discusses previous literature on dengue and its economic and tourism impact. Section 4.3 discusses climate conditions in Aruba and the island's tourism industry. In Section 4.4, the data and the applied methodology are reviewed. In Section 4.5, results and discussion are presented, whereas Section 6 concludes and offers policy implications and lines for future research.

\subsection{A Review of the Literature}

\subsubsection{Dengue}

Dengue is the most important viral vector-borne disease and an increasing problem globally (Gratz \& Knudsen, 1996). In 1944, Dr. Albert Sabin isolated and identified the dengue virus (Chakraborty, 2008). The disease is caused by one of the four related, yet distinct viruses named dengue virus 1 (DEN-1), dengue virus 2 (DEN-2), dengue virus 3 (DEN-3), and dengue virus 4 (DEN-4) (Gubler \& Kuno, 1997), and transmission depends on vulnerable populations living in urban environments where sanitation is poor, and rainfall run-off water accumulates. Dengue viruses are spread from viremic to susceptible human beings (host) by the mosquito (vector) Aedes aegypti and Aedes 
albopictus (Kovats, Campbell-Lendrum, Reid, \& Martens, 2000). The mosquitoes attain the virus when they feed on a viremic person. The mosquito can transmit dengue if it immediately bites another host or after 8-12 days of viral replication in its salivary glands, the so-called extrinsic incubation period (Chakraborty, 2008). The mosquito stays infected for the remainder of its 15to 65-day lifespan. Vertical transmission of dengue virus in mosquitoes has been noted, whereby therefore infected mosquitoes can pass the virus on to their young. The female mosquito lays its eggs on walls of both artificial and natural water containers. The eggs of Aedes mosquitoes can withstand long periods of desiccation, as long as one year (Chakraborty, 2008). Once a host gets infected, it has an intrinsic incubation period of 3-14 days. After the incubation, a 5- to 7-day acute febrile (fever) illness ensues. Healing usually is complete within 7-10 days. When a host gets infected with one type of dengue virus, it provides lifelong protection from re-infection with that same serotype, but only partial and short-lived protection from infection with other dengue serotypes (Chakraborty, 2008). Persons who have had a prior infection with one or more dengue serotypes can develop a more severe form of dengue, namely, dengue hemorrhagic fever or dengue shock syndrome. Two main factors that regulate Aedes aegypti populations are, namely, climate and available breeding sites. Climatic parameters, such as humidity and temperature, have an influence on dengue transmission, for example, during high humidity periods, mosquito survivals are longer and can increase the chance of transmission (Gubler \& Kuno, 1997). Higher temperatures can shorten the extrinsic incubation period and produce smaller females that are forced to make more blood meals to obtain the amount of protein needed for egg production, therefore increasing the number of individuals infected by a single female (Gubler \& Kuno, 1997). High ambient temperatures can even have a more powerful effect on the vector mosquito population than increased moisture accompanying a rainy season (Halstead, 2008). Wind can also induce 
an influence on the Aedes aegypti. The Aedes aegypti has a flight range from $2.5 \mathrm{~km}$ per day in an open environment to a few hundred to less than $25 \mathrm{~m}$ in an urban environment (Halstead, 2008).

\subsubsection{Economic Impact of Dengue}

Dengue fever/dengue hemorrhagic fever can have enormous economic consequences, placing significant burdens on affected communities. The impact can include loss of life; medical expenditures for sick patients; loss in productivity due to workers on sick leave; strain on health care services due to sudden, high demand during an epidemic; expenditures for emergency control actions; and loss of tourism as a result of negative publicity (Meltzer et al., 1998). Costs estimates related to dengue in the Caribbean region include losses of US\$ 8 million in Puerto Rico and US\$ 103 million in Cuba (Halstead, 2008). The cost of the illness includes both direct (medical costs) and indirect costs (value of the lost time entailing lost wages, etc.) (Suaya, Shepard, \& Beatty, 2007). Costs related to intervention can be considered research and development costs, household insecticide expenditure, and government vector control programs. Separate from the immediate costs, vector-borne diseases such as dengue can also have other costs such as mortality, long-term morbidity, adverse influences on education, economic growth, reduced per capita income, and reduced foreign direct investments (Mavalankar, Puwar, Murtola, \& Vasan, 2009). A method for estimating costs associated with dengue illnesses of all degrees of severity (mortality and morbidity) employs disability-adjusted life years (DALY's) (Halstead, 2008). In Puerto Rico, between 1984 and 1994, the economic burden due to dengue was estimated at 658 DALY's per year per million inhabitants. This value was found to be as important as that for tuberculosis and sexually transmitted diseases (except for HIV/AIDS). 


\subsubsection{Tourism and Dengue Connection}

From anecdotal and published materials, it is inferred that tourism can be influenced by natural events (seismological and meteorological events), sociopolitical instabilities, and epidemic outbreaks. In the age of globalization, enhanced mobility and labor flow related to international travel act as an essential factor for the spreading of infectious diseases. All tourism destinations are somewhat sensitive to climate. Tourist destinations can be either positively or negatively influenced by climate variability that induces climate anomalies that influence a tourist's comfort, safety, and the products that attract tourists or deter tourists, such as infectious diseases (Scott, Lemieux, \& Malone, 2011). A downturn in tourism demand, during epidemics, can harm the local economy (Yoshikawa \& Kusriastuti, 2013). Vector-borne diseases such as dengue and malaria can induce epidemics, which could influence tourism demand. Some authors hypothesized that take-off benefits associated with the decision to eliminate vector-borne diseases such as malaria might manifest positively in foreign direct investments, including tourism growth (Sabot et al., 2010). Except for the local burden induced by a vectorborne disease on a tourist destination, the disease can influence the tourist itself. A study done by Wichmann et al. (2003) shows that health care providers in European travel clinics are more and more confronted with dengue. They noted that infections were acquired in all endemic regions of the globe, with the highest frequencies in Southeast Asia. Wichmann et al. (2003) indicated that at the root of the emergence of dengue are changes in human demography and behavior and also increased air travel of humans who are incubating the virus and thus providing an ideal mechanism for transporting pathogens among population centers of the tropics. Therefore, travelers have the potential to not only acquire a dengue infection but also to extend new and potentially more virulent strains to diverse areas of the world. Schwartz et al. (2008) examined seasonality and annual trends for dengue cases among 
returned travelers and noticed that dengue cases indicated region-specific peaks for Southeast Asia, South-central Asia, South, and the Caribbean. As noted by Wichmann et al., (2004), despite all terrorist threats and economic crises in recent years, in 2002, the number of international tourist arrivals exceeded 700 million for the first time in history. This increase, together with the increasing frequency of dengue in the tropics, is responsible for increased chances that health care providers will be confronted with imported dengue virus infection. Secondly, travelers might introduce more virulent strains into areas with mild cases and introduce the dengue virus into non-endemic areas where the mosquito vector as Aedes aegypti is present.

Over the last one-hundred-plus years, tourism has become the world's largest business, surpassing defense, manufacturing, oil, and agriculture industries and is a significant contributor to economies worldwide, where international tourist arrivals and the number of destinations increased (Lundberg, Krishnamoorthy, \& Stavenga, 1995; Goeldner \& Ritchie, 2009; Scott et al., 2011; UNWTO, 2014). To keep up-to-date with the rapidly growing tourism phenomenon, destinations need sufficient forecasts of tourism demand for planning and managerial decisions (Goh, 2012). Vanegas and Croes (2000) indicated that there needs to be at first an adequate insight into the factors that influence tourism demand. Then, a detailed understanding of the patterns of development of tourism demand over time is necessary. Many studies on the determinants of tourism demand have been concentrated around economic factors (e.g., income and price) (Goh, 2012). According to Mavalankar et al. (2009), the quantification of the impact of various epidemics on tourism revenues is still inadequately addressed in peer-reviewed literature. Reported dengue cases can act as a deterrent for a tourist when selecting a tourist destination. In a study done on malaria, another vector-borne disease, it was reported that many persons canceled their trips to Northern KwaZulu-Natal in the 1999/2000-malaria season. The high percentage of cancellations was due 
to the epidemic and extensive media coverage (Maartens, Sharp, Curtis, Mthembu, \& Hatting, 2007). A survey conducted by Maartens et al. (2007) found that tourism operators believed that malaria risk has a significant impact on the foreign tourist market. Viral diseases such as SARS also show an effect on tourism through the reduction of inflow of foreign tourists, the reduction of tourist spending due to shorter stays, and reduction in premium visitors (Rossi \& Walker, 2005).

\subsection{Case Study}

\subsubsection{Climate Conditions of Aruba}

The island of Aruba is located in the tropics and has a tropical steppe, hot semiarid climate. The wind blows for more than $95 \%$ of the time from the northeast and the southeast direction over Aruba, at an average speed of $7.3 \mathrm{~m}$ $\mathrm{s}^{-1}$ at a 10-meter distance (1981-2010). Minimum wind speed is observed in October and November, and maximum wind speed is observed from May to July (Departamento Meteorologico Aruba, 2014). Aruba's average temperature is $27.9^{\circ}$ Celsius while varying during the year from $19.0^{\circ}$ Celsius to $36.5^{\circ}$ Celsius. The coldest months are January and February, and the hottest ones are August and September. On average (1981-2010), Aruba receives $471.1 \mathrm{~mm}$ of rain. The wettest months are from October to December, and the driest months are from March to May. The potential for thunderstorms in Aruba is low, as compared to the rest of the tropics. Aruba has, on average, only 17.9 days per year, where a thunderstorm passes over the observation site. The average relative humidity is $77.4 \%$, and the average cloud coverage in Aruba is $47.3 \%$ (Departamento Meteorologico Aruba, 2014). 


\subsubsection{The Tourism Industry of Aruba}

Aruba has 50 plus years of experience with the tourism industry. Starting from 1959 , the island built its first 100-room hotel, modeled after similar ones in Florida and Puerto Rico (Cole \& Razak, 2009). However, the tourism industry played only a small role in the overall economic development of the island, given the dominant position of an oil refinery, the Lago Oil \& Transport Company, Ltd. (Vanegas \& Croes, 2000). This situation changed drastically in 1985, when the oil refinery closed its doors, considerably shocking the Aruban economy. At that time, the refinery contributed to about $25 \%$ of Aruba's gross domestic product (GDP) and directly and indirectly employed 30\%-40\% of Aruba's population (Ridderstaat, 2007).

This unfavorable situation forced the government to start searching for a new source of economic activity. Experts showed that the most obvious way to increase income and foreign exchange receipts was to expand the tourism industry. Therefore, new hotels, shopping malls, and other commercial buildings were initiated. The number of hotel rooms more than tripled from 1986 to 2011. The majority of visitors came by airplane, and the number of aircraft landings almost doubled from 1986 to 2011 (Ridderstaat, Oduber, Croes, Nijkamp, \& Martens, 2014). The number of stay-over visitors, cruise passengers, and tourism receipts grew substantially from 1986 to 2011.

The United States tourist represents the leading market for Aruba, accounting, on average, for roughly $63.5 \%$ of all stay-over visitors between 1981 and 2011. Most of these American tourists come from, particularly the northeastern part of the United States (Ridderstaat et al., 2014). 


\subsection{Data and Methodology}

The basis for this study is the conceptual scheme depicted in Figure 4.1, where seasonal factors of cruise tourism and stay-over tourism are set against those of dengue cases. Climate plays a mediating role between dengue and tourism, as it can affect both. Ridderstaat et al. (2014) showed that climate is a significant push and pull factor influencing tourism demand. While other studies such as Pham, Doan, Phan, and Minh (2011) showed that climate acts as a main determinant of dengue fever. These studies are hinting for the mediating role of climate in dengue and tourism. According to Matzarakis (2006), the most relevant meteorological parameters for tourism include air temperature, air humidity, wind speed, wind direction, cloud coverage, sunshine duration, or radiations fluxes, rain and precipitation, snow coverage, and water temperature. According to Gubler and Kuno (1997), the most relevant meteorological parameters for dengue variability include air temperature, air humidity, and rainfall. For this research, we use five weather fundamentals (cloud coverage, relative humidity, rainfall, temperature, and wind). The variable temperature was further sub-divided into average maximum and minimum temperatures and average temperature, as was proposed by other authors such as Wongkoon, Jaroensutasinee, and Jaroensutasinee (2011) and Gharbi et al. (2011). 


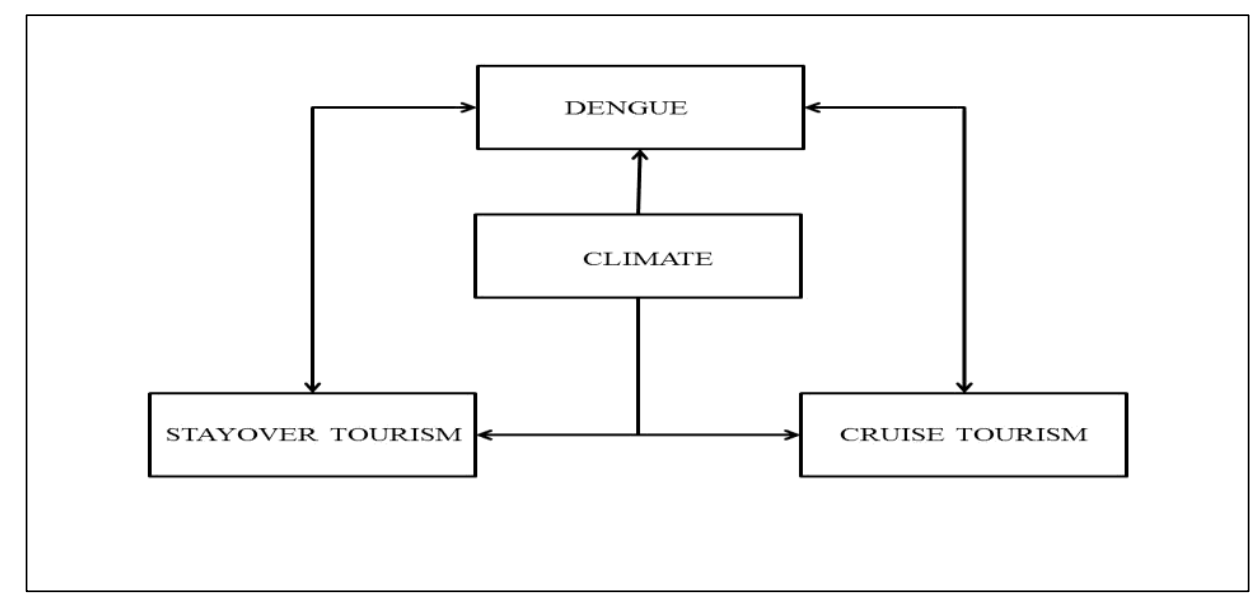

Figure 4.1: Conceptual framework of the relationship among dengue, tourism demand, and climate.

The variables used in this study are shown in Table 4.1. Dengue cases for Aruba $\left(A U A \_D E N G U E\right)$ are proxied by suspected dengue cases and are available for the years 1999-2011 from the Department of Public Health. This is due to the limited amount of laboratory-verified years. Furthermore, laboratory-confirmed cases accounted for almost 90\% of epidemiology suspected cases, when looking at years that had both laboratory-confirmed cases and epidemiology suspected cases. 
Table 4.1: Variables used in the analysis.

\begin{tabular}{|c|c|c|c|}
\hline Variable type & Data description & Data period & Source \\
\hline \multicolumn{4}{|l|}{ Epidemiology } \\
\hline AUA_DENGUE & $\begin{array}{l}\text { Suspected dengue cases in } \\
\text { Aruba }\end{array}$ & $1999-2011$ & Department of Public Health \\
\hline \multicolumn{4}{|l|}{ Tourism demand } \\
\hline CRUISE_TOUR & $\begin{array}{l}\text { Tourism demand from } \\
\text { cruises }\end{array}$ & 1999-2011 & Central Bank of Aruba \\
\hline TOT_TOUR & Total tourism demand & 1999-2011 & Central Bank of Aruba \\
\hline \multicolumn{4}{|l|}{ Weather } \\
\hline AUA_CLOUD & Cloud coverage in Aruba & $1999-2011$ & $\begin{array}{l}\text { Meteorological Department of } \\
\text { Aruba }\end{array}$ \\
\hline AUA_RH & Relative humidity in Aruba & 1999-2011 & $\begin{array}{l}\text { Meteorological Department of } \\
\text { Aruba }\end{array}$ \\
\hline AUA_RAIN & Rainfall in Aruba & 1999-2011 & $\begin{array}{l}\text { Meteorological Department of } \\
\text { Aruba }\end{array}$ \\
\hline AUA_TEMP & $\begin{array}{l}\text { Average temperature in } \\
\text { Aruba }\end{array}$ & 1999-2011 & $\begin{array}{l}\text { Meteorological Department of } \\
\text { Aruba }\end{array}$ \\
\hline AUA_WIND & Wind in Aruba & 1999-2011 & $\begin{array}{l}\text { Meteorological Department of } \\
\text { Aruba }\end{array}$ \\
\hline AUA_MAX & $\begin{array}{l}\text { Average maximum } \\
\text { temperature in Aruba }\end{array}$ & 1999-2011 & $\begin{array}{l}\text { Meteorological Department of } \\
\text { Aruba }\end{array}$ \\
\hline AUA_MIN & $\begin{array}{l}\text { Average minimum } \\
\text { temperature in Aruba }\end{array}$ & 1999-2011 & $\begin{array}{l}\text { Meteorological Department of } \\
\text { Aruba }\end{array}$ \\
\hline
\end{tabular}

Tourism demand or flow is proxied separately by the total number of stay-over visitors (TOT_TOUR) and the total number of cruise visitors (CRUISE_TOUR) for the years of 1981-2011. These data are from the Central Bank of Aruba. Meteorological data for Aruba, consisting of relative humidity ( $\left.A U A \_R H\right)$, rainfall (AUA_RAIN), temperature (AUA_TEMP), maximum temperature $\left(A U A \_M A X\right)$, minimum temperature $\left(A U A \_M I N\right)$, wind $\left(A U A \_W I N D\right)$, and cloud coverage (AUA_CLOUD) are available for the years of 1981-2011, from the Meteorological Department of Aruba.

A Box-Cox power transformation has transformed all series in order to make the distribution values more symmetrical and induce a variancestabilizing effect (Wilks, 1995). Osborne (2010) showed that Box-Cox power transformations were superior to traditional transformations, such as square 
root, log, and inverse. The best transformation parameter was chosen using Hinkley's $d_{\lambda}$ statistic (Wilks, 1995).

Following Yu, Schwartz, and Walsh (2010), this study is based on the notion that time series can be decomposed into four different time-varying components (i.e., trend, cycle, incidental, and seasonal components). According to $\mathrm{Yu}$ et al. (2010), concentrating on seasonal components allows for the possibility to examine parameters, such as weather, dengue cases, and tourism demand in different seasons of the year. Also, by using seasonal components, we can, for example, determine how similar the dengue cases are from those of tourism demand: The more similar they are, the more significant the impact of dengue case seasonality is on tourism demand seasonality, and vice versa.

Prior to applying the Census X-12 technique, the data were analyzed for the type of model (additive or multiplicative) they belong to. We apply the following regression, adapted from den Butter and Fase (1991), to assess the model type:

$\left|Y-Y_{T}\right|=\alpha+\beta Y_{T}+\varepsilon_{t}$

where:

$Y=$ The original value of the time series;

$Y_{T}=$ The centralized moving average of $Y$ over a year;

$\alpha, \beta=$ Coefficients;

$\varepsilon=$ Error.

If $Y$ and $Y_{T}$ are uncorrelated, meaning that the coefficient $\beta$ is not significantly different from zero, the model type is additive. If $\beta$ is significantly different from zero, the model is multiplicative.

After applying the Census X-12 methodology, all series were changed to standardized anomalies in order to work simultaneously with a group of data that are associated but not strictly comparable (Hart \& Grumm, 2001). 
The standardized anomalies are dimensionless quantities. Standardized anomalies also remove the influence of location and spread from the data (Wilks, 1995).

One can test for the relative importance of seasonal (SF), trend-cyclic (TC), and irregular factors (IR) in the overall short-term volatility of the applied variables by doing the following regression borrowed from Ridderstaat et al. (2014):

$\Delta$ Series $_{t}=\alpha_{1} \Delta$ Series $_{E l, t}+\varepsilon_{1, t}$

where:

$\Delta=$ First difference;

$E l=$ Series' element $(\mathrm{TC}, \mathrm{SF}$, or IR $)$;

$t=$ Time;

$\varepsilon=$ Residual.

The aim here is to determine the coefficient of determination (adjusted $R^{2}$ ) in order to assess the contribution of each of these three elements to the variability of the overall series. Given that the differencing occurs on a shorttime range (i.e., month versus the next month), it is expected that the effects of the monthly differences would be likely dominated by a combination of both SF and IR elements.

Afterward, the time series were transformed into a balanced panel data type. Panel data consist of a time series for each cross-sectional member in the data set. Panel data have several advantages over pure cross-sections or purely time series (Asteriou \& Hall, 2007). Some of the advantages of panel data include: controlling for individual heterogeneity, more informative data, more variability, more degrees of freedom, less collinearity, and studying dynamics of adjustments better (Baltagi, 2008).

In order to access the correct unit root test, a Mann-Kendall seasonal trend test was performed on the series. Mann-Kendall test is a statistical trend assessment broadly used in climatology (Mavromatis \& Stathis, 2011) and 
hydrology time-series studies (Yue \& Wang, 2004). The Mann-Kendall test is non-parametric and, therefore, does not require the data to be normally distributed. The Mann-Kendall test also has a low sensitivity to abrupt breaks due to inhomogeneous time series (Tabari, Somee, \& Zadeh, 2011). The MannKendall test is based on the $S$-statistic (Önöz,\& Bayazit, 2003). Each pair of observed values $x_{i}, x_{j},(i>j)$ of the random variable is examined to gauge whether $x_{i}>x_{j}$ or $x_{i}<x_{j}$. Let the number of the first type of pairs is $P$ and the number of the latter type of pairs is $M$, then $S$ is described as $S=P-M$. For $n$ $>10$, the sampling distribution of $S$ is as follows, where $Z$ follows the standard normal distribution:

$$
Z= \begin{cases}\frac{S-1}{\sigma s}, & \text { if } S>0 \\ 0, & \text { if } S=0 \\ \frac{S+1}{\sigma s}, & \text { if } S<0\end{cases}
$$

and $\sigma_{s}=\sqrt{(n(n-1)(2 n+5)) / 18}$.

The null hypothesis that there is no trend is rejected when the computed $Z$ value is greater than $Z_{\alpha / 2}$ in absolute value.

Next, we proceeded to test for stationarity in panel data by applying Levin, Lin, and Chu's (2002) unit root. Levin et al. (2002) proposed to test the null hypothesis of $\mathrm{H}_{0}: \delta=0$ against the alternative hypothesis of $\mathrm{H}_{1}: \delta<0$ using:

$$
\Delta y_{i t}=\delta y_{i t-1}+\sum_{L=1}^{P_{i}} \theta_{i L} \Delta y_{i t-L}+\alpha_{m i} d_{m t}+\varepsilon_{i t}, \quad m=1,2,3
$$

where $d_{m t}$ denotes the deterministic components, $\alpha_{m i}$ denotes the corresponding vector of coefficients for model $m=1,2,3$, and $\varepsilon_{i, t}$ is assumed to be independently distributed across $i$ and $t$ where $i=1, \ldots, N$ and $t=1, \ldots, T$. The normalized bias and the pseudo $t$-ratio that corresponds with the pooled 
Ordinary Least Squares (OLS) estimation of $\delta$ in Equation (3), once have been properly normalized, converge to a standard limit distribution as $N \rightarrow \infty, T \rightarrow$ $\infty$ in a way that $\sqrt{N} / T \rightarrow 0$.

After the unit root test, the study proceeded to analyze whether climate data and tourism demand data were important contributing factors in the number of dengue cases in Aruba. In order to do this, we tested three types of panel models, i.e.: (1) a pooled OLS regression model, (2) a fixed-effects model (FEM), and (3) a random-effects model (REM). The following equations and methodological analyses were based on Baltagi (2008). The following pooled OLS models were tested:

$$
\begin{aligned}
& A U A_{-} D E N G U E_{-} I R_{-} S F_{i, t}=\alpha_{i, t}+\alpha_{2} A U A_{-} C L O U D_{-} S F_{i, t}+\alpha_{3} A U A_{-} R A I N_{-} S F_{i, t} \\
& +\alpha_{4} A U A_{-} T E M P \_S F_{i, t}+\alpha_{5} A U A_{-} M A X_{-} S F_{i, t}+\alpha_{6} A U A_{-} M I N_{-} S F_{i, t} \\
& +\alpha_{7} A U A_{-} \text {WIND_SF } F_{i, t}+\alpha_{8} A U A_{-} R H_{-} S F_{i, t}+ \\
& \alpha_{9} T O T \_T O U R_{-} S F_{i, t}+u_{i, t} \\
& \text { TOT_TOUR_SF } F_{i, t}=\alpha_{i, t}+\alpha_{17} A U A_{-} C L O U D_{-} S F_{i, t}+\alpha_{18} A U A_{-} R A I N_{-} S F_{i, t} \\
& +\alpha_{19} A U A_{-} T E M P \_S F_{i, t}+\alpha_{20} A U A_{-} M A X_{-} S F_{i, t}+\alpha_{21} A U A_{-} M I N_{-} S F_{i, t} \\
& +\alpha_{22} A U A_{-} W I N D_{-} S F_{i, t}+\alpha_{23} A U A_{-} R H_{-} S F_{i, t} \\
& +\alpha_{24} D E N G U E_{-} I R \_S F_{i, t}+u_{i, t} \\
& \text { CRUISE_TOUR_SF } F_{i, t}=\alpha_{i, t}+\alpha_{25} A U A_{-} C L O U D_{-} S F_{i, t}+\alpha_{26} A U A_{-} R A I N_{-} S F_{i, t} \\
& +\alpha_{27} A U A_{-} T E M P \_S F_{i, t}+\alpha_{28} A U A_{-} M A X_{-} S F_{i, t}+\alpha_{29} A U A_{-} M I N_{-} S F_{i, t} \\
& +\alpha_{30} A U A_{-} W I N D_{-} S F_{i, t}+\alpha_{31} A U A_{-} R H_{-} S F_{i, t} \\
& +\alpha_{32} \text { DENGUE_IR_SF } F_{i, t}+u_{i, t} \\
& A U A_{-} D E N G U E_{-} I R_{-} S F_{i, t}=\alpha_{i, t}+\alpha_{2} A U A_{-} C L O U D_{-} S F_{i, t}+\alpha_{10} A U A_{-} R A I N_{-} S F_{i, t} \\
& +\alpha_{11} A U A_{-} T E M P \_S F_{i, t}+\alpha_{12} A U A_{-} M A X_{-} S F_{i, t}+\alpha_{13} A U A_{-} M I N_{-} S F_{i, t} \\
& +\alpha_{14} A U A_{-} W I N D_{-} S F_{i, t}+\alpha_{15} A U A_{-} R H_{-} S F_{i, t} \\
& +\alpha_{16} \text { CRUISE_TOUR_SF } F_{i, t}+u_{i, t}
\end{aligned}
$$


where:

$i=1, \ldots, 12$;

$t=1999, \ldots, 2011$;

$A U A \_D E N G U E \_I R \_S F=$ Dengue irregular and seasonal factors;

$A U A \_C L O U D \_S F=$ Cloud coverage in Aruba seasonal factors;

$A U A \_R A I N \_S F=$ Rainfall in Aruba seasonal factors;

$A U A \_T E M P \_S F=$ Temperature in Aruba seasonal factors;

$A U A \_M A X \_S F=$ Maximum temperature in Aruba seasonal factors;

$A U A \_M I N \_S F=$ Minimum temperature in Aruba seasonal factors;

$A U A \_W I N D \_S F=$ Wind in Aruba seasonal factors;

$A U A \_R H \_S F=$ Relative humidity in Aruba seasonal factors;

$T O T \_T O U R \_S F=$ Stay-over tourism in Aruba seasonal factors;

CRUISE_TOUR_SF $=$ Cruise tourism in Aruba seasonal factor;

$\alpha$ 's $=$ Coefficients;

$u=$ Residual.

The FEM is indicated as follows:

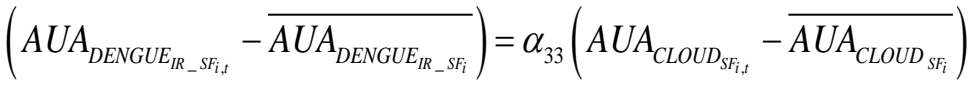

$$
\begin{aligned}
& +\alpha_{34}\left(A U A_{\text {RAIN }_{S F_{i, t}}}-\overline{A U A_{\text {RAIN }_{S F_{i}}}}\right)+\alpha_{35}\left(A U A_{\text {TEMP }_{S S_{i, i}}}-\overline{A U A_{\text {TEMS }_{S F_{i}}}}\right) \\
& +\alpha_{36}\left(A U A_{M A X_{S F_{i, t}}}-\overline{A U A_{M A X_{S F_{i}}}}\right)+\alpha_{37}\left(A U A_{M N_{S F_{i, t}}}-\overline{A U A_{M I N_{S F_{i}}}}\right) \\
& +\alpha_{38}\left(A U A_{W I N D_{S F_{i, t}}}-\overline{A U A_{W I N D_{S F_{i}}}}\right)+\alpha_{39}\left(A U A_{R H_{S F_{i, t}}}-\overline{A U A_{R H_{S F_{i}}}}\right) \\
& +\alpha_{40}\left(A U A_{\text {TOT_ROUR }_{S S_{i, t}}}-\overline{A U A_{\text {TOT_TOUUR }_{S F_{i}}}}\right)+u_{i, t}
\end{aligned}
$$




$$
\begin{aligned}
& \left(A U A_{D E N G U E_{I R_{-} S F_{i, t}}}-\overline{A U A_{D E N G U E_{I R_{-} S F_{i}}}}\right)=\alpha_{41}\left(A U A_{C_{L O U D_{S F_{i, t}}}}-\overline{A U A_{C L O U D_{S F_{i}}}}\right) \\
& +\alpha_{42}\left(A U A_{R_{A I N} F_{F_{i, t}}}-\overline{A U A_{R_{A I N}}}\right)+\alpha_{S F_{i}}\left(A U A_{T E M P_{S F_{i, t}}}-\overline{A U A_{T E M P_{S F_{i}}}}\right) \\
& +\alpha_{44}\left(A U A_{M A X_{S F_{i, t}}}-\overline{A U A_{M A X_{S F_{i}}}}\right)+\alpha_{45}\left(A U A_{M I N_{S F_{i, t}}}-\overline{A U A_{M I N}}\right) \\
& +\alpha_{46}\left(A U A_{W I N D_{S F_{i, t}}}-\overline{A U A_{W I N D_{S F_{i}}}}\right)+\alpha_{47}\left(A U A_{R H_{S F_{i, t}}}-\overline{A U A_{R H_{S F_{i}}}}\right) \\
& +\alpha_{48}\left(A U A_{\text {CRUISE_TOUR }_{S F_{i, t}}}-\overline{\text { AUA }_{\text {CRUISE_TOUR }_{S F_{i}}}}\right)+u_{i, t} \\
& \left(A U A_{T^{\prime} T_{-} T O U R_{I R_{-} S F_{i, t}}}-\overline{A U A_{\text {TOT_TOUR }_{I R_{-} S F_{i}}}}\right)=\alpha_{49}\left(A U A_{\text {CLOUD }_{S F_{i, t}}}-\overline{A U A_{C L O U D_{S F_{i}}}}\right) \\
& +\alpha_{50}\left(A U A_{\text {RAIN }_{S F_{i, t}}}-\overline{A U A_{\text {RAIN }_{S F_{i}}}}\right)+\alpha_{51}\left(A U A_{T E M P_{S F_{i, t}}}-\overline{A U A_{T E M P_{S F_{i}}}}\right) \\
& +\alpha_{52}\left(A U A_{M A X_{S F_{i, t}}}-\overline{A U A_{M A X_{S F_{i}}}}\right)+\alpha_{53}\left(A U A_{M I N_{S F_{i, t}}}-\overline{A U A_{M I N}}\right) \\
& +\alpha_{54}\left(A U A_{W I N D_{S F_{i, t}}}-\overline{A U A_{W I N D_{S F_{i}}}}\right)+\alpha_{55}\left(A U A_{R H_{S F_{i, t}}}-\overline{A U A_{R H_{S F_{i}}}}\right) \\
& +\alpha_{56}\left(A U A_{D E N G U E_{I R_{-} S F_{i, t}}}-\overline{A U A_{D E N G U E_{I R_{-} S F_{i}}}}\right)+u_{i, t}
\end{aligned}
$$

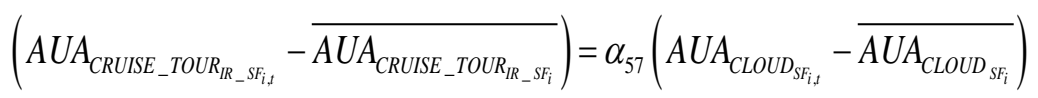

$$
\begin{aligned}
& +\alpha_{58}\left(A U A_{\text {RAIN }_{S F_{i, t}}}-\overline{A U A_{\text {RAIN }_{S F_{i}}}}\right)+\alpha_{59}\left(A U A_{\text {TEMP }_{S F_{i, t}}}-\overline{A U A_{T E M P_{S F_{i}}}}\right) \\
& +\alpha_{60}\left(A U A_{M A X_{S F_{i, t}}}-\overline{A U A_{M A X_{S F_{i}}}}\right)+\alpha_{61}\left(A U A_{M_{N_{S F_{i, t}}}}-\overline{A U A_{M I N_{S F_{i}}}}\right) \\
& +\alpha_{62}\left(A U A_{W I N D_{S F_{i, t}}}-\overline{A U A_{W I N D_{S F_{i}}}}\right)+\alpha_{63}\left(A U A_{R H_{S F_{i, t}}}-\overline{A U A_{R H_{S F_{i}}}}\right) \\
& +\alpha_{64}\left(A U A_{D E N G U E_{I R_{-} S F_{i, t}}}-\overline{A U A_{D E N G U E_{I R_{-} S F_{i}}}}\right)+u_{i, t}
\end{aligned}
$$

To determine whether the FEM is superior to the pooled OLS model, we calculated a restricted $F$-test, which compares the coefficients of determination of both pooled OLS and FEM (Gujarati, 2011). 
The REM model is expressed as follows:

$$
\begin{gathered}
\text { AUA_DENGUE_IR_SF } F_{i, t}=\alpha_{i, t}+\alpha_{65} A U A_{-} C L O U D_{-} S F_{i, t}+\alpha_{66} A U A_{-} R A I N_{-} S F_{i, t} \\
+\alpha_{67} A U A_{-} T E M P_{-} S F_{i, t}+\alpha_{68} A U A_{-} M A X_{-} S F_{i, t}+\alpha_{69} A U A_{-} M I N_{-} S F_{i, t} \\
+\alpha_{70} A U A_{-} W I N D_{-} S F_{i, t}+\alpha_{71} A U A_{-} R H_{-} S F_{i, t} \\
+\alpha_{72} T O T_{-} T O U R_{-} S F_{i, t}+w_{i, t}
\end{gathered}
$$

where $w_{i, t}=\varepsilon_{i}+u_{i, t}$

$$
\begin{gathered}
\text { AUA_DENGUE_IR_SF } F_{i, t}=\alpha_{i, t}+\alpha_{73} A U A_{-} C L O U D_{-} S F_{i, t}+\alpha_{74} A U A_{-} R A I N_{-} S F_{i, t} \\
+\alpha_{75} A U A_{-} T E M P_{-} S F_{i, t}+\alpha_{76} A U A_{-} M A X_{-} S F_{i, t}+\alpha_{77} A U A_{-} M I N_{-} S F_{i, t} \\
+\alpha_{78} A U A_{-} \text {WIND_SF } F_{i, t}+\alpha_{79} A U A_{-} R H_{-} S F_{i, t} \\
+\alpha_{80} \text { CRUISE_TOUR_SF } F_{i, t}+w_{i, t}
\end{gathered}
$$

where $w_{i, t}=\varepsilon_{i}+u_{i, t}$

$$
\begin{gathered}
\text { TOT_TOUR_SF } F_{i, t}=\alpha_{i, t}+\alpha_{81} A U A_{-} C L O U D_{-} S F_{i, t}+\alpha_{82} A U A_{-} R A I N_{-} S F_{i, t} \\
+\alpha_{83} A U A_{-} T E M P_{-} S F_{i, t}+\alpha_{84} A U A_{-} M A X_{-} S F_{i, t}+\alpha_{85} A U A_{-} M I N_{-} S F_{i, t} \\
+\alpha_{86} A U A_{-} W I N D_{-} S F_{i, t}+\alpha_{87} A U A_{-} R H_{-} S F_{i, t} \\
+\alpha_{88} D E N G U E_{-} I R_{-} S F_{i, t}+w_{i, t}
\end{gathered}
$$

where $w_{i, t}=\varepsilon_{i}+u_{i, t}$.

$$
\begin{gathered}
\text { CRUISE_SF } F_{i, t}=\alpha_{i, t}+\alpha_{89} A U A_{-} C L O U D_{-} S F_{i, t}+\alpha_{90} A U A_{-} R A I N_{-} S F_{i, t} \\
+\alpha_{91} A U A_{-} T E M P_{-} S F_{i, t}+\alpha_{92} A U A_{-} M A X_{-} S F_{i, t}+\alpha_{93} A U A_{-} M I N_{-} S F_{i, t} \\
+\alpha_{94} A U A_{-} W I N D_{-} S F_{i, t}+\alpha_{95} A U A_{-} R H_{-} S F_{i, t} \\
+\alpha_{96} D E N G U E_{-} I R_{-} S F_{i, t}+w_{i, t}
\end{gathered}
$$

where $w_{i, t}=\varepsilon_{i}+u_{i, t}$.

Essentially, the error term $w_{i, t}$ is composed of an individual-specific error $\left(\varepsilon_{i}\right.$, with a mean of zero and variance of ${\sigma_{\varepsilon}}^{2}$ ) and a combined time series and crosssection error component. Additionally, the REM assumes that the intercept of any cross-section unit is not fixed, but a random variable with a mean value of $\alpha_{1}$ can thus be expressed as: 


$$
\alpha_{1, i}=\alpha_{1}+\varepsilon_{i}
$$

The Hausman test was conducted to investigate the adequacy of the REM against the FEM, where the null hypothesis is that both the FEM and the REM do not differ significantly. The test involves a comparison of a calculated $\chi^{2}$ against a critical $\chi^{2}$. If the calculated $\chi^{2}$ is larger than the critical $\chi^{2}$, we can then conclude that the REM is not the appropriate model and that the FEM is preferred to be over REM (Baltagi, 2008). The Breusch-Pagan Lagrange multiplier (LM) test was also conducted to investigate the adequacy of the REM against the pooled OLS. The Breusch-Pagan LM test's null hypothesis is that the variance across entities is zero (Torres-Reyna, 2014).

Based on the results of the models, we calculated the monthly differences between the seasonal factors of dengue cases and the statistically significant seasonal factors of tourism. The results of these calculations will provide indications of the strength of association during several periods of the year. For this purpose, we used the Mahalanobis distance measure formula. The Mahalanobis distance is the distance between two points in $k$-dimensional space, scaled by the statistical variation in each dimension of the space. For instance, if $x$ and $y$ are two observations on a set of $k$ variables with covariance matrix $C$, then the Mahalanobis distance between the observations is given by $\sqrt{(x-y)^{\prime} C^{-1}(x-y)}$ where $(x-y)$ is a $k$-vector (Cottrell \& Lucchetti, 2012).

The smaller the Mahalanobis distance result, the stronger the influence of the variables with each other. Mahalanobis distance calculation was used in other epidemiology studies, such as the European Centre for Disease Prevention and Control, to assess areas vulnerable to dengue in Europe. In their study, this institute used the Mahalanobis distance to gauge the degree of climatic difference that exists between Europe and the known places of dengue transmission (European Centre for Disease Prevention and Control, 2012). 


\subsection{Results and Discussion}

All estimates were obtained from using the following combinations of software, Eviews, Gretl, Stata, and R. Firstly, and all variables were subjected to power transformations. The best transformation parameter was chosen using Hinkley's d $\lambda$ statistic (Wilks, 1995) (see Table 4.2). After the appropriate power transformation, regression results show that most of the variables have the additive form, except for the variables AUA_RH and AUA_MIN, which were found to be multiplicative (see Table 4.3), based on an $\alpha$-value of 0.05 . According to Ellison and Gotelli (2004), using a low critical value as 0.05 , one can be confident that the patterns in the data can be quite strong; humans are psychologically predisposed to recognizing and seeing patterns in data even if they do not exist and a low critical value would safeguard against this.

Table 4.2: Best $\lambda$ used for power transformation.

\begin{tabular}{ll}
\hline Variable & $\lambda$ \\
\hline AUA_DENGUE & 0 \\
AUA_CLOUD & 1 \\
AUA_RH & -0.5 \\
AUA_RAIN & 0 \\
AUA_TEMP & 1 \\
AUA_WIND & 1 \\
AUA_MAX & 1 \\
AUA_MIN & 1 \\
CRUISE_TOUR & 1 \\
TOT_TOUR & 0 \\
\hline
\end{tabular}


Table 4.3: Model type on monthly data.

\begin{tabular}{llll}
\hline Variable & $\begin{array}{l}\text { Regression result } \\
\text { of } \beta\end{array}$ & Model type & $p$-value 5\% \\
\hline AUA_DENGUE & 0.036853 & Additive & 0.39 \\
AUA_CLOUD & -0.013634 & Additive & 0.86 \\
AUA_RAIN & -0.04328 & Additive & 0.74 \\
AUA_TEMP & -0.240273 & Additive & 0.11 \\
AUA_WIND & -0.11038 & Additive & 0.14 \\
AUA_RH & 0.198499 & Multiplicative & 0.00 \\
AUA_MIN & -0.2757 & Multiplicative & 0.03 \\
AUA_MAX & -0.003725 & Additive & 0.94 \\
CRUISE_TOUR & 0.260215 & Additive & 0.06 \\
TOT_TOUR & 0.007241 & Additive & 0.88 \\
\hline
\end{tabular}

Table 4.4: Explanatory power of time-series elements.

\begin{tabular}{llll}
\hline Dependent variable & Adj. $R^{2}$ IR & Adj. $R^{2}$ TC & Adj. $R^{2}$ SF \\
\hline d_AUA_CLOUD & 0.50 & 0.02 & 0.48 \\
d_AUA_RH & 0.70 & 0.08 & 0.22 \\
d_AUA_RAIN & 0.71 & 0.09 & 0.20 \\
d_AUA_TEMP & 0.20 & 0.11 & 0.69 \\
d_AUA_WIND & 0.45 & 0.03 & 0.52 \\
d_AUA_MAX & 0.74 & 0.03 & 0.23 \\
d_AUA_MIN & 0.32 & 0.06 & 0.62 \\
d_AUA_DENGUE & 0.71 & 0.05 & 0.24 \\
d_CRUISE_TOUR & 0.14 & 0.00 & 0.86 \\
d_TOT_TOUR & 0.15 & 0.05 & 0.80
\end{tabular}

Note: $\mathrm{d}_{-}=$First difference of variable; Adj. $R^{2}=$ Adjusted coefficient of determination. The higher the Adj. $R^{2}$ is, the more explanatory power an element of the variable has; IR $=$ Irregular values, $\mathrm{TC}=$ Trend-cycle values, $\mathrm{SF}=$ Seasonal values.

The regression results from the analysis of short-term explanatory power indicate that indeed, both seasonal and irregular factors explained most of the short-range variability of the series, with the seasonal factors explaining more than $50 \%$ of the variability in stay-over tourism, cruise tourism, average temperature, average minimum temperature, and wind speed in Aruba (see Table 4.4). 
This suggests that the causation of the short-term volatility of the indicated variables is mainly due to repeating factors over time. Concerning dengue incidences, $24 \%$ of the short-term change was due to seasonal factors, while $71 \%$ was due to irregular factors (AUA_DENGUE_IR_SF). Given the last outcome, we proceeded to define dengue incidences as a combined factor of irregular and seasonal factors. The other variables remained as seasonal factors, in order to see if the seasonality of the variables can still be used to explain dengue occurrence in Aruba. After the regression results from the analysis of short-term explanatory power, the remaining series were standardized.

Table 4.5: Mann-Kendall results.

\begin{tabular}{lll}
\hline Seasonal value & Characteristic & Probability \\
\hline AUA_DENGUE_SF & Trend & 0.00 \\
AUA_CLOUD_SF & Trend & 0.00 \\
AUA_RH_SF & Trend & 0.00 \\
AUA_RAIN_SF & Trend & 0.00 \\
AUA_TEMP_SF & Trend & 0.00 \\
AUA_WIND_SF & Trend & 0.00 \\
AUA_MAX_SF & Trend & 0.00 \\
AUA_MIN_SF & Trend & 0.00 \\
CRUISE_TOUR_SF & Trend & 0.00 \\
TOT_TOUR_SF & No trend & 0.42 \\
AUA_DENGUE_IR_SF & Trend & 0.00 \\
\hline
\end{tabular}


Table 4.6: Panel unit root results.

\begin{tabular}{|c|c|c|c|c|}
\hline Variable & $\begin{array}{l}\mathrm{I}(0) \\
\text { degree of } \\
\text { integration }\end{array}$ & $\begin{array}{l}\mathrm{I}(1) \\
\text { degree of } \\
\text { integration }\end{array}$ & $\begin{array}{l}\mathrm{I}(2) \\
\text { degree of } \\
\text { integration }\end{array}$ & Assumption \\
\hline AUA_CLOUD_SF & $-16^{* * * *}$ & & & $\begin{array}{l}\text { Intercept and } \\
\text { trend }\end{array}$ \\
\hline AUA_RAIN_SF & $-10.7277^{* * * *}$ & & & $\begin{array}{l}\text { Intercept and } \\
\text { trend }\end{array}$ \\
\hline AUA_RH_SF & $-2.21377^{* * *}$ & & & $\begin{array}{l}\text { Intercept and } \\
\text { trend }\end{array}$ \\
\hline AUA_TEMP_SF & $-19.9411^{* * *}$ & & & $\begin{array}{l}\text { Intercept and } \\
\text { trend }\end{array}$ \\
\hline AUA_WIND_SF & & $-1.6154^{* *}$ & & $\begin{array}{l}\text { Intercept and } \\
\text { trend }\end{array}$ \\
\hline AUA_MAX_SF & $-8.00545^{* * * *}$ & & & $\begin{array}{l}\text { Intercept and } \\
\text { trend }\end{array}$ \\
\hline AUA_MIN_SF & $-8.24008^{* * *}$ & & & $\begin{array}{l}\text { Intercept and } \\
\text { trend }\end{array}$ \\
\hline AUA_DENGUE_SF & $-18^{* * * *}$ & & & $\begin{array}{l}\text { Intercept and } \\
\text { trend }\end{array}$ \\
\hline AUA_DENGUE_IR_SF & $-8.49^{* * * *}$ & & & $\begin{array}{l}\text { Intercept and } \\
\text { trend }\end{array}$ \\
\hline CRUISE_TOUR_SF & $-21.3229^{* * *}$ & & & $\begin{array}{l}\text { Intercept and } \\
\text { trend }\end{array}$ \\
\hline TOT_TOUR_SF & $-6.37573^{* * * *}$ & & & Intercept \\
\hline
\end{tabular}

Notes: ${ }^{* * *},{ }^{* *}$, and ${ }^{*}$ reflect significance at the levels of $1 \%, 5 \%$, and $10 \%$, respectively. $\mathrm{SF}=$ Seasonal factors; $\mathrm{IR}=$ Irregular factors.

After standardization, all variables were transformed to panel data, and a Mann-Kendall trend test was conducted, in order to delineate whether both intercept and trend should be applied in the unit root equation (see Table 4.5). The results indicate in most cases that both trend and intercept should be applied. Afterward, the test for stationarity, using Levin et al. (2002) unit root test, was conducted. The maximum lag selection was based on the Schwarz Information Criterion. The results are included in Table 4.6 above and show that most variables are integrated of zero-order, meaning that they are already stationary. Only the seasonal variable representing wind showed signs of being I(1). Therefore, this variable was dropped, and we proceeded with the stationary variables only. Since the remaining variables were integrated at level order, no cointegration is possible (Asteriou \& Hall, 2007). Table 4.7 provides 
the results of the tested equations. The variables $A U A \_M I N \_S F$ and $A U A \_T E M P \_S F$ were dropped from the regressions due to collinearity, given that their variance inflation factors were above 10 (Kennedy, 2013).

Table 4.7: Panel regression results.

\begin{tabular}{|c|c|c|c|c|}
\hline Variable & $\begin{array}{l}\text { REM } \\
\text { AUA_- } \\
\text { DENGUE } \\
\text { _IR_SF }\end{array}$ & $\begin{array}{l}\text { Pooled OLS } \\
\text { AUA_- } \\
\text { DENGUE_IR } \\
\text { SF }\end{array}$ & $\begin{array}{l}\text { FEM } \\
\text { CRUISE_ } \\
\text { TOUR_SF }\end{array}$ & $\begin{array}{l}\text { REM } \\
\text { TOT_TOUR } \\
\text { _SF }\end{array}$ \\
\hline AUA_CLOUD_SF & $-0.60 * * *$ & $-0.24 * *$ & 0.06 & $-0.29^{* * * *}$ \\
\hline AUA_RH_SF & -0.02 & 0.02 & 0.00 & 0.07 \\
\hline AUA_RAIN_SF & 0.09 & -0.07 & $-0.21^{* * *}$ & 0.08 \\
\hline AUA_MAX_SF & 0.04 & 0.02 & $0.14^{* * *}$ & $0.11^{* * *}$ \\
\hline CRUISE_TOUR_SF & & $0.69^{* * *}$ & & \\
\hline TOT_TOUR_SF & -0.02 & & & \\
\hline AUA_DENGUE_IR_SF & & & 0.015 & 0.01 \\
\hline
\end{tabular}

The first equation calculated was $A U A \_D E N G U E \_I R \_S F$ as an independent variable, and $\quad A U A \_R A I N \_S F, \quad A U A \_M A X \_S F, \quad A U A \_R H \_S F$, $A U A \_C L O U D \_S F$, and TOT_TOUR_SF as dependent variables. The BreuschPagan test showed that the REM is superior to the pooled OLS $\left(A U A \_D E N G U E \_I R \_S F: 16.99, p=0.000\right)$ and the Hausman test showed that the REM is superior to the FEM to estimate the impact of seasonal factors of dengue incidences on the tourism demand variables and climate variables (AUA_DENGUE_IR_SF: 7.47, $p=0.187$ ). We, therefore, used the REM model for the estimates. No relationship was noted for the seasonal movement of stayover tourism (TOT_TOUR_SF) and dengue. Since the stay-over tourist is defined as a tourist who arrives by airplanes and stays at least 24 hours in Aruba, this indicates that the virus is not imported via airplanes to Aruba, and the stay-over tourist does not act as a host to disperse the virus in Aruba. Possible stay-over visitors infected with the virus would probably cancel the airline trip or postpone it till they recover. Also, most stay-over tourists 
(63.5\%) arrive from the USA, and most of them from the Northeast sector (Ridderstaat et al., 2014).

The prevalence of dengue in the Northeast sector of the USA is also low (Centers for Disease Control and Prevention [CDC], 2014). Therefore, we would expect a no-relationship between dengue incidences and stay-over tourists. The only significant value was for cloud amount, hinting an increase in dengue when there is less cloud. The cloud amount in Aruba fluctuates a lot. On the one hand, one can expect an increase in cloud coverage during the dry season due to upper-level clouds.

On the other hand, decreases and increases can be observed during the wet season. Since no relationship was found with rainfall, we could assume that dengue incidence fluctuations observed with cloud coverage fluctuations are not rain-related. Moreno (2010) observed that beach tourists are drawn or withdrawn by certain climate factors, for example, precipitation, wind, hours of sunlight, and cloud coverage, which all fall within the aesthetic facet of climate and have an influence on enjoyment and attractiveness of a site (De Freitas, 2001). Therefore, weather variables, such as cloud amounts, can trigger specific human responses. Gubler and Kuno (1997) indicated that the probability of contact among humans, viruses, and the mosquito is easier in any Aedes aegypti infected location where people congregate, resulting in transmission either from an infective vector to a host or from a viremic host to an uninfected vector. Therefore, less cloud coverage will probably cause more people to congregate outdoor and aid in the transmission of the virus. Of interest was that we found no statistical relationship with rainfall in Aruba. This contradicts other studies conducted in the Caribbean (Chadee, Shivnauth, Rawlins, \& Chen, 2007), which did see a seasonal relationship between rainfall and dengue. On the other hand, studies done by Gubler and Kuno (1997) and Lu et al. (2009) showed that at times, no correlation could be established between rainfall and dengue. 
The second equation calculated was $A U A \_D E N G U E \_I R \_S F$ as an independent variable, and $\quad A U A \_R A I N \_S F, \quad A U A \_M A X \_S F, \quad A U A \_R H \_S F$, $A U A \_C L O U D \_S F$, and CRUISE_TOUR_SF as dependent variables. The Breusch-Pagan test (AUA_DENGUE_IR_SF: 0.244, $p=0.621$ ), the Hausman test (AUA_DENGUE_IR_SF: 5.57, $p=0.350$ ), and the $F$-statistic test (AUA_DENGUE_IR_SF: $1.787, p=0.062)$ showed that pooled OLS is the most superior model for this relationship. Since we are using pooled OLS and in pooled OLS, standard errors can be serially correlated, we proceeded, according to Cameron and Trivedi (2005) to control for this by clustering the standard errors on the panel unit index (month) variable. The model indicated that cruise tourism (CRUISE_TOUR_SF) would have a positive effect on dengue incidences.

In the last decades, the passenger shipping industry, including cruise ships, has expanded considerably. The World Health Organization (WHO) indicates that in 2008, 13 million passengers traveled by cruise ships to all continents, including areas that are not easily accessible by other means of travel. On average, a cruise lasts about seven days, but some can last several months. Cruise ships can carry now, on average, 3,000 passengers and 1,000 crew (WHO, 2010). In Aruba, the number of cruise calls in 1981 was 79 and increased to 332 in 2011, a growth rate of $320 \%$. The number of cruise visitors in 1981 was 54,971 and 599,893 in 2011, which indicates a whopping growth rate of almost 991\% (Aruba Central Bureau of Statistics, 2014). A cruise survey done by Aruba Central Bureau of Statistics in 2002 indicated that almost $59 \%$ of cruise-surveyed tourists came from the US. Another survey conducted in 1997 indicated that almost 68\% came from the US, which would hint that the proportion of tourists from other countries is increasing on the cruise ships visiting Aruba (Aruba Central Bureau of Statistics, 2014).

The increase in dengue-related cases to increase in cruise tourism could have a dual explanation. First, this could indicate that tourists coming 
through the harbor could be carrying the virus; therefore, they are likely to introduce the virus to the available vectors (mosquitoes), which later infect the local population. On a cruise ship, one can expect different nationalities, where a cruise vacation may involve many stops. Passengers may also be dropped off or picked up at multiple ports. All these patterns increase the potential risks of infectious disease exposures (WHO, 2010). Data corroborate that cruise ships have served as a mode of disease outbreaks, where passengers then disperse the infection elsewhere. The closed and crowded environment on a ship allows easy transmission of pathogens, and the short duration of the cruise can allow an infected tourist to reach another location before the onset of symptoms (Chen \& Wilson, 2008). For example, in 1990, a passenger onboard a ship became the index case of an outbreak and influenced 205 residents in Italy (Chen \& Wilson, 2008). The passenger was infected with chikungunya and passed the virus to mosquitoes, which passed it to the local population. Chikungunya is another viral disease that can be transmitted in the same way as dengue and has roughly the same incubation period (Chakraborty, 2008). The WHO estimates that in the last 30 years, more than 100 disease outbreaks were related to ships. The WHO states that the number of reported outbreaks might be an underestimate since many go undetected or are not reported (WHO, 2010). As dengue has a short incubation period, a passenger can acquire the virus at another port of call and become viremic when reaching Aruba. Once in Aruba, the passenger can pass it along the vectors. A survey conducted by Aruba Central Bureau of Statistics in 2002 indicated that almost $80 \%$ of the money spent in Aruba by a cruise tourist would be done in shopping. Since almost all stores that cruise tourists visit are close to the cruise terminal in downtown Oranjestad, this would automatically create a convergence flux of people downtown, while the cruise ship is in harbor, thus increasing the chances of virus transmission (Aruba Central Bureau of Statistics, 2014). 
Second, except for cruise ships introducing infected hosts, there also exists a probability that the infected vector was transported on a ship (Gubler \& Kuno, 1997; Halstead, 2008). Therefore, the "illegal" vector will introduce the virus to the local population, and afterward, the virus is further distributed via the regular manner. According to Halstead (2008), adult mosquitoes can be transported through various sources, but both Aedes aegypti and Aedes albopictus are now very widely distributed around the world, thus making the transport of viremic humans a more critical mechanism now responsible for the introduction of dengue viruses across national borders instead of an "illegal" vector. Hence, one would expect that the chance of an infected tourist coming onshore and passing the virus to the available vectors would be more significant than the chance of the virus being carried by an infected vector coming onshore. As was the case for the earlier equation, we noticed here again that the value of the cloud amount showed a significant negative relationship for dengue incidences. The same reasoning can be applied for the explanation of this variable.

The third equation calculated had TOT_TOUR_SF as an independent variable, and $\quad A U A \_R A I N \_S F, \quad A U A \_M A X \_S F, \quad A U A \_R H \_S F$, $A U A \_C L O U D \_S F$, and $A U A \_D E N G U E \_I R \_S F$ as dependent variables. The $F$ statistics (TOT_TOUR_SF: 232.159, $p=0.000$ ), the Breusch-Pagan test (TOT_TOUR_SF: 719.752, $p=0.000)$, and the Hausman test (TOT_TOUR_SF: $3.30, p=0.654)$ showed that the REM was superior to the FEM and the pooled OLS. Dengue incidences had no relation to stay-over tourism incidences. This further corroborates the earlier conclusion that stay-over tourism fluctuations did not influence dengue as the dependent variable. This also shows that the socalled lock-in effect may influence Aruba. The lock-in effect means that even under changing circumstances, the amount of tourism visits stays the same. For example, Moreno (2010) indicated that as much as 54\% of Europeans preferred to spend their vacations in conventional, well-known tourist destinations and 
would not change their plans due to changing circumstances. In the case of Aruba, a changing circumstance could increase dengue cases, but even so, the tourist would still choose Aruba as a destination due to its popularity.

The fourth equation had CRUISE_TOUR_SF as an independent variable, and $A U A \_R A I N \_S F, A U A \_M A X \_S F, A U A \_R H \_S F$, $A U A \_C L O U D \_S F$, and $A U A \_D E N G U E \_I R \_S F$ as dependent variables. The $F$ statistics showed that the FEM was superior to the pooled OLS (CRUISE_TOUR_SF: 239.405, $p=0.025$ ). The Breusch-Pagan test showed that the REM is superior to the pooled OLS (CRUISE_TOUR_SF: 429.919, $p=$ 0.000). The Hausman test showed that the FEM is superior to the REM to estimate the impact of seasonal factors of dengue incidences on the tourism demand variables and climate variables (CRUISE_TOUR_SF: 35.349, $p=$ 0.000). We, therefore, conclude that the FEM model is superior to the other models. The model showed that dengue incidences could not cause cruise tourism to increase or decrease, while earlier, we showed that cruise tourism itself could influence dengue cases. This, again, can be explained by the earliermentioned lock-in effect.

The Mahalanobis distances were subsequently calculated for seasonal factors of cruise tourism (CRUISE_TOUR_SF), cloud amount (AUA_CLOUD_SF), and fluctuations of dengue incidences. Table 4.8 indicates the months where the Mahalanobis distance outcomes were smaller than the average; this can be used as a proxy when the sensitivity of the seasonal factors of dengue incidences to those of cruise tourism and cloud coverage was the highest. Here, one can deduce that sensitivity to seasonal factors of cruise tourism was the most pertinent in February, April-July, and October-November and in March, June-July, September, November, and December for cloud amount. 
Table 4.8: Months where Mahalanobis distance is below average.

\begin{tabular}{|c|c|c|}
\hline \multirow{2}{*}{ Month of the year } & \multicolumn{2}{|c|}{ Dengue } \\
\hline & Cruise tourism & Cloud amount \\
\hline \multicolumn{3}{|l|}{ January } \\
\hline February & $\bullet$ & \\
\hline March & & • \\
\hline April & $\bullet$ & \\
\hline May & $\bullet$ & \\
\hline June & $\bullet$ & $\bullet$ \\
\hline July & $\bullet$ & $\bullet$ \\
\hline \multicolumn{3}{|l|}{ August } \\
\hline September & & • \\
\hline October & $\bullet$ & \\
\hline November & - & $\bullet$ \\
\hline December & & - \\
\hline
\end{tabular}

Note: $\bullet$ indicates that the Mahalanobis distance is below its average.

Since cruise tourists are not measured by countries of origin in Aruba every year, and the trip is usually already underway for a while, one can assume that most tourists would not cancel their cruises to avoid Aruba in the case of a dengue outbreak. Moreover, if they acquired dengue symptoms, they would still stay on the cruise and continue their travel, as was the case in Italy with chikungunya (Chen \& Wilson, 2008). Since most cruises do not originate from Aruba and cruise tourists are not regularly archived statistically on the departure of origin upon arrival in Aruba, we could not use the Mahalanobis distance sensitivity idea to track the climatological condition at the originating tourist country that could influence dengue transmission. Therefore, we could not calculate the chances that the tourist would get infected at his/her departing country before arriving in Aruba. Additionally, most tourists would have 
passed through different ports of call before arriving in Aruba, making any calculations on where a tourist could have gotten infected almost impossible.

\subsection{Conclusion}

Dengue is the most critical viral vector-borne disease and a growing problem globally (Gratz \& Knudsen, 1996). Studies recommend that if one eliminates vector-borne diseases such as malaria, it may manifest positively in foreign direct investments, including tourism growth (Sabot et al., 2010). The purpose of this study was to investigate the influence of seasonal patterns of dengue on stay-over tourism, cruise tourism, and climate patterns. This study found that as the number of cruise tourists increased, dengue would also increase in Aruba. A mutual connection was also studied, but no relation was found between an increase of dengue in Aruba and a decrease of tourists (stay-over and cruise) in Aruba.

Economists calculate the burden of vector-borne diseases as the sum of the cost of illness and the cost of intervention programs (Mavalankar et al., 2009), where the cost of the illness includes both direct (medical costs) and indirect costs (value of the lost time entailing lost wages, etc.) (Suaya et al., 2007). Yoshikawa and Kusriastuti (2013) showed that the average cost related to one case of dengue in Malaysia would be US\$ 445 of the government health care budget being spent on the disease. In Thailand, it was estimated in 2005 at US\$ 573 for non-fatal hospitalization of dengue infection. In Aruba, it is estimated that a cruise tourist would spend around US\$ 112 a day (Aruba Central Bureau of Statistics, 2014). This shows as a paradox that even though the cruise tourist would spend money in Aruba, it could leave a higher cost behind. 
Due to the relationship between cruise tourism and dengue incidences in Aruba, it is recommended to increase vector surveillance and control near the harbor area of Oranjestad, Aruba, where cruise ships dock. According to Gubler and Kuno (1997), passive dispersal is common by all types of transport, including trains, ships, and planes. Therefore, the International Sanitary Regulations require that an area within $400 \mathrm{~m}$ of international ports and airports be kept free of Aedes aegypti. Except for vector surveillance, dengue surveillance among cruise travelers is advisable since residents are exposed to the dengue virus through international travelers. Dengue surveillance in travelers would also serve to exclude the possibility of importation of other serious diseases that can spread to other persons by secondary transmission. Now with the emergence of chikungunya, another arthropod virus transmitted to humans by Aedes species, in the Caribbean, it is of greater importance that governments, such as in Aruba, increase their vector surveillance and control strategies (Pan American Health Organization [PAHO], 2014). Since there is no effective vaccine for dengue, transmission can only be reduced by measures against the mosquito ${ }^{13}$. Many countries have dengue control programs; with limited exceptions, these were far less effective than their yellow fever forerunners (Gubler \& Kuno, 1997). Several factors have been attributed to this limited success, namely, the explosive growth of urban areas, limited government sources, poor management, resistance to insecticide, overemphasis on government intervention, and insufficient education of the public (Gubler \& Kuno, 1997). Since 1985, the PAHO relinquished the goal of hemispheric eradication and endorsed the concept of the elimination of dengue through control of Aedes aegypti. PAHO also introduced the concept of integrated vector control, where countries should combine all available control methods in the most effective, economical, and safe manner to maintain vector populations at reasonable levels (PAHO, 1994).

\footnotetext{
${ }^{13}$ When the article was published, no vaccines for dengue existed yet. As of the date of writing (October 2020), there is still no effective vaccine available (https://lci.rivm.nl/richtlijnen/dengue).
} 
Future research should focus on extending this investigation to further investigate the tourism markets for Aruba itself, for example, North American, European, and Asian countries, to get a complete picture of the influence of dengue and tourism in Aruba. Moreover, this study could be expanded to include other destinations in the Caribbean. It is also recommended that in order to improve the current understanding of the complex dengue systems, the development of an integrated assessment model that includes evolutionary, spatial, and local dynamics of ecological, environmental, social, demographic, and behavioral factors be applied in Aruba. 


\section{References}

Aruba Central Bureau of Statistics. (2014). Cruise survey 1997 and 2002. Retrieved from (http://www.cbs.aw).

Asteriou, D., \& Hall, S. G. (2007). Applied econometrics: A modern approach using eviews and microfit. New York, N.Y.: Palgrave Macmillan.

Baltagi, B. (2008). Econometric analysis of panel data. New York, N.Y.: John Wiley \& Sons.

Cameron, A. C., \& Trivedi, P. K. (2005). Microeconometrics: Methods and applications.Cambridge: Cambridge University Press.

Centers for Disease Control and Prevention [CDC]. (2014). CDC-dengue.

Centers for Disease Control and Prevention. Retrieved from http://www.cdc.gov/dengue/.

Chadee, D. D., Shivnauth, B., Rawlins, C. S., \& Chen, A. A. (2007). Climate, mosquito indices, and the epidemiology of dengue fever in Trinidad (2002-2004). Annals of Tropical Medicine and Parasitology, 101(1), 69-77.

Chakraborty, T. (2008). Dengue fever and other hemorrhagic viruses. New York, N.Y.: Chelsea House.

Chen, L. H., \& Wilson, M. E. (2008). The role of the traveler in emerging infections and magnitude of travel. Medical Clinics of North America, 92(6), 1409-1432.

Cobelens, F. G., Groen, J., Osterhaus, A. D., Leentvaar-Kuipers, A., Wertheimvan Dillen, P. M. \& Kager, P. A. (2002). Incidence and risk factors of probable dengue virus infection among Dutch travellers to Asia.

Tropical Medicine and International Health, 7(4), 331-338.

Cole, S., \& Razak, V. (2009). How far, and how fast? Population, culture, and carrying capacity in Aruba. Futures, 41(6), 414-425.

Cottrell, A., \& Lucchetti, R. (2012). Gretl user's guide. Distributed with the Gretl library.

Croes, R. R. (2006). A paradigm shift to a new strategy for small island economies: Embracing demand side economics for value enhancement and long term economic stability.Tourism Management, 27(3), 453465.

Den Butter, F.A.G., \& Fase, M.M.G. (1991). Seasonal Adjustment as a Practical Problem. Elsevier Science Publishers, North-Holland.

De Freitas, C. R. (2001, October). Theory, concepts and methods in tourism climate research. In Proceedings of the First International Workshop on Climate, Tourism and Recreation (pp. 3-20). A. Matzarakis and CR de Freitas.

Departamento Meteorologico Aruba. (2014). Retrieved from http://www.meteo.aw.

Eisenhardt, K. M., \& Graebner, M. E. (2007). Theory building from cases: Opportunities and challenges. Academy of Management Journal, 50(1), 25-32. 
Ellison, G. N., \& Gotelli, N. J. (2004). A primer of ecological statistics. Massachusetts: Sinauer.

European Centre for Disease Prevention and Control. (2012). The climatic suitability for Dengue transmission in continental Europe.

Retrieved from

http://ecdc.europa.eu/en/publications/publications/ter-climaticsuitablility-dengue.pdf.

Gharbi, M., Quenel, P., Gustave, J., Cassadou, S., Ruche, G. L., Girdary, L., \& Marrama, L. (2011). Time series analysis of dengue incidence in Guadeloupe, French West Indies: Forecasting models using climate variables as predictors. BMC Infectious Diseases, 11(1), 166.

Goeldner, C. R., \& Ritchie, J. B. (2009). Tourism: Principles, practices, philosophies. Hoboken, N.J.: John Wiley \& Sons.

Goh, C. (2012). Exploring impact of climate on tourism demand. Annals of Tourism Research, 39(4), 1859-1883.

Gratz, N. G., \& Knudsen, A. B. (1996). The rise and spread of dengue, dengue hemorrhagic fever, and its vectors. A historical review (up to 1995). Geneva: World Health Organization.

Gubler, D. J., \& Kuno, G. (1997). Dengue and dengue hemorrhagic fever. Wallingford, U.K.: CAB International.

Gujarati, D. N. (2011). Econometrics by example. Hampshire, U.K.: Palgrave Macmillan.

Halstead, S. B. (2008). Dengue (Vol. 5). London: Imperial College Press.

Hart, R. E., \& Grumm, R. H. (2001). Using normalized climatological anomalies to rank synoptic-scale events objectively. Monthly Weather Review, 129(9), 2426-2442.

Kennedy, P. (2013). A guide to econometrics. Cambridge, Massachusetts: MIT Press.

Kovats, R. S., Campbell-Lendrum, D., Reid, C., \& Martens, P. (2000). Climate and vector borne disease: an assessment of the role of climate in changing disease patterns. Maastricht: International Centre for Integrative Studies, Maastricht University.

Levin, A., Lin, C. F., \& Chu, C. S. J. (2002). Unit root tests in panel data: Asymptotic and finite-sample properties. Journal of Econometrics, 108(1), 1-24.

Lu, L., Lin, H., Tian, L., Yang, W., Sun, J., \& Liu, Q. (2009). Time series analysis of dengue fever and weather in Guangzhou, China. BMC Public Health, 9(1), 395.

Lundberg, D. E., Krishnamoorthy, M., \& Stavenga, M. H. (1995). Tourism economics. New York, N.Y.: John Wiley \& Sons.

Maartens, F., Sharp, B., Curtis, B., Mthembu, J., \& Hatting, I. (2007). The impact of malaria control on perceptions of tourists and tourism operators concerning malaria prevalence in KwaZulu-Natal, 1999/2000 versus 2002/2003. Journal of Travel Medicine, 14(2), 96-104. 
Matzarakis, A. (2006). Weather- and climate-related information for tourism. Tourism and Hospitality Planning and Development, 3(2), 99-115.

Mavalankar, D. V., Puwar, T. I., Murtola, T. M., \& Vasan, S. S. (2009). Quantifying the impact of chikungunya and dengue on tourism revenues. IIMA Working Papers, No WP2009-02-03, Indian Institute of Management Ahmedabad, Research and Publication Department.

Mavromatis, T., \& Stathis, D. (2011). Response of the water balance in Greece to temperature and precipitation trends. Theoretical and Applied Climatology, 104(1-2), 13-24.

Meltzer, M. I., Rigau-Perez, J. G., Clark, G. G., Reiter, P., \& Gubler, D. J. (1998). Using disability-adjusted life years to assess the economic impact of dengue in Puerto Rico: 1984-1994. The American Journal of Tropical Medicine and Hygiene, 59(2), 265-271.

Moreno, A. (2010). Climate change and tourism: Impacts and vulnerability in coastal Europe (Doctoral thesis, Universitaire Pers Maastricht).

Önöz, B., \& Bayazit, M. (2003). The power of statistical tests for trend detection. Turkish journal of engineering and environmental sciences, 27(4), 247-251.

Osborne, J. W. (2010). Applying the Box-Cox transformation. Practical Assessment, Research, and Evaluation, 15(12), 1-9.

Pan American Health Organization [PAHO]. (1994). Dengue and dengue hemorrhagic fever in the Americas: Guidelines for prevention and control. Scientific Publication No. 548. Washington, D.C.: Pan American Health Organization.

Pan American Health Organization [PAHO]. (2014). Chikungunya. Retrieved from (http://www.paho.org).

Pham, H. V., Doan, H. T., Phan, T. T., \& Minh, N. N. (2011). Ecological factors associated with dengue fever in a central highlands province, Vietnam. BMC Infectious Diseases, 11(1), 172.

Ridderstaat, J. (2007). The Lago story: The compelling story of an oil company on the island of Aruba. Editorial Charuba.

Ridderstaat, J., Oduber, M., Croes, R., Nijkamp, P., \& Martens, P. (2014). Impacts of seasonal patterns of climate on recurrent fluctuations in tourism demand: Evidence from Aruba. Tourism Management, 41, 245-256.

Rossi, V., \& Walker, J. (2005). Assessing the economic impact and costs of flu pandemics originating in Asia. L-20 Project Paper.

Sabot, O., Cohen, J. M., Hsiang, M., Kahn, J. G., Basu, S., Tang, L., \& Feachem, R. (2010). Costs and financial feasibility of malaria elimination. The Lancet, 376(9752), 1604-1615. 
Schwartz, E., Weld, L. H., Wilder-Smith, A., von Sonnenburg, F., Keystone, J. S., Kain, K. C., \& GeoSentinel Surveillance Network. (2008). Seasonality, annual trends, and characteristics of dengue among ill returned travelers, 1997-2006. Emerging Infectious Diseases, 14(7), 1081-1088.

Scott, D. J., Lemieux, C. J., \& Malone, L. (2011). Climate services to support sustainable tourism and adaptation to climate change. Climate Research, 47(1/2), 111-122.

Stienlauf, S., Segal, G., Sidi, Y., \& Schwartz, E. (2005). Epidemiology of travel-related hospitalization. Journal of Travel Medicine, 12(3), 136141.

Suaya, J. A., Shepard, D. S., \& Beatty, M. E. (2007). Dengue: burden of disease and costs of illness. In TDR. Report of the Scientific Working Group Meeting on Dengue (Vol. 1, pp. 35-49).

Tabari, H., Somee, B. S., \& Zadeh, M. R. (2011). Testing for long-term trends in climatic variables in Iran. Atmospheric Research, 100(1), 132-140.

Thacker, N., \& Perrelli, R. (2012). Caribbean growth in an international perspective: The role of tourism and size.

Torres-Reyna, O. (2014). Panel data analysis fixed and random effects (using Stata 10.x). Data \& Statistical Services. Retrieved from http://www.princeton.edu/ otorres/.

United Nations Environment Programme [UNEP]. (2005). Making tourism more sustainable: A guide for policy makers. UNEP \& UNWTO.

UNWTO (2014). UNWTO Annual Report 2013. Retrieved May 15, 2014, from http://media.unwto.org/publication/unwto-annual-report-2013.

Vanegas, M., \& Croes, R. R. (2000). Evaluation of demand: US tourists to Aruba. Annals of Tourism Research, 27(4), 946-963.

Wichmann, O., Hongsiriwon, S., Bowonwatanuwong, C., Chotivanich, K., Sukthana, Y., \& Pukrittayakamee, S. (2004). Risk factors and clinical features associated with severe dengue infection in adults and children during the 2001 epidemic in Chonburi, Thailand. Tropical Medicine and International Health, 9(9), 1022-1029.

Wichmann, O., Muhlberger, N., \& Jelinek, T. (2003). Dengue-The underestimated risk in travellers. Dengue Bulletin, 27, 126-137.

Wilks, D. S. (1995). Statistical methods in the atmospheric sciences. New York, N.Y.: Academic Press.

Wongkoon, S., Jaroensutasinee, M., \& Jaroensutasinee, K. (2011). Climatic variability and dengue virus transmission in Chiang Rai, Thailand. Biomedica, 27, 5- 13.

WHO (2010). International travel and health: Situation as on 1 January 2010. World Health Organization.

Yin, R. K. (2009). Case study research: Design and methods (4th ed.). Thousand Oaks, C.A.: Sage Publications, Inc. 
Yoshikawa, M. J., \& Kusriastuti, R. (2013). Surge of dengue virus infection and chikungunya Fever in bali in 2010: the burden of mosquito-borne infectious diseases in a tourist destination. Tropical medicine and health, 2011-05.

Yu, G., Schwartz, Z., \& Walsh, J. E. (2010). Climate change and tourism seasonality. Journal of Tourism, 11(2).

Yue, S., \& Wang, C. (2004). The Mann-Kendall test modified by effective sample size to detect trend in serially correlated hydrological series. Water Resources Management, 18(3), 201-218. 

Part III:

Gradient in Vegetation 


\title{
5. The Connection of Vegetation with Tourism Development and
} Economic Growth: A Case Study for Aruba ${ }^{l}$

\begin{abstract}
Vegetation is an integral part of the ecosystem on earth. It influences the earth's system in many ways. Any influences on this fragile variable should be investigated, especially in a changing climate. Humans can have a positive or negative influence on plants. This document examines the possible relationship between tourism development, economic growth, and vegetation density using an Autoregressive Distributed Lag Model approach to test cointegration, with subsequent application of Vector Error Correction or Vector Autoregressive models to test causality between the three variables. The proposed framework contributes to a better understanding of the use of remote sensors to monitor the change in vegetation density linked to tourism development and economic growth. It thus offers opportunities to improve the overall strategy for achieving sustainable development in a small island state. The calculations showed that there were relationships between the tourism demand and economic growth on the vegetation density on Aruba for the western part of the island. On the other hand, for the central part of the island, no relationships were found. Moreover, no bilateral relationships were found running from vegetation density towards tourist demand and economic growth.
\end{abstract}

Keywords: Normalized difference vegetation index, tourism development, vector error correction model, vector autoregressive model, small island, Aruba

1. This chapter is based on Oduber, M., Ridderstaat, J., and Martens, P. (2015). The connection of vegetation with tourism development and economic growth: A case study for Aruba. Journal of Environmental Science and Engineering, 4, 420-431. 


\subsection{Introduction}

Human activities can have a detrimental effect on the environment. The environment itself has limited resources compared to the unlimited demands of society. Increased awareness on this has meant a re-evaluation of the methods of planning for future development, where a greater emphasis is put on the need to preserve these environmental resources for future generations, through the process of sustainable development (Apostolopoulos \& Gayle, 2002; Farquhar, Clayton, \& Retalis, 2005). This can be viewed principally actively in areas with a rapid increase in resource demand, such as in areas of high tourism activity. Tourism is one of the key factors in the increased urbanization and destruction of natural habitat in different coastal tourist destinations (Caribbean Tourism Organization, 2011). Over the years, the number of tourists visiting the Caribbean regions has increased significantly, from 166 million overnight stays in 1970 to more than 935 million in 2010 (Caribbean Tourism Organization, 2011). In order to meet the growing demand for tourism, large areas of the coast have been developed for tourism activities, leading to concerns about the aesthetic and ecological conditions and the possible reduction of both the quality of life of residents and the economic potential for tourism. (Apostolopoulos \& Gayle, 2002). The most pressing environmental concerns for the Caribbean include biodiversity loss, urbanization, soil erosion, desertification, water conservation, and climate change (UNEP, 2012). These effects may manifest in land cover changes, water shortages, soil erosion, air and water pollution, desertification, and increased occurrences of forest fires leading to deforestation (UNEP, 2012). Consequently, any development, such as tourism, needs to be accomplished under the principles of sustainable development in order to minimize environmental damage (Farquhar et al. 2005)). Sustainable development is particularly an issue for small island states, as they tend to have more fragile and limited natural resources. There is also an economic necessity to guard the environment, as its aesthetic appearance is a 
significant component of a regions' attractiveness to tourists (Farquhar et al. ,2005). A general strategy is necessary for designing schemes that can analyze the existing and past developments and, therefore, be able to forecast an adequate, sustainable development plan for upcoming generations. Increased knowledge of the state of the region's environment is studied, which is a prerequisite in order to be sure that development in that region falls within sustainable strategies. The effective use of earth observation and satellite remote sensing data combined with a suitable blend of socio-economic data may aid in realizing not only a local specific direction to accomplish sustainable development of an area of interest but similarly in monitoring the environmental effects of any developmental activities employed under various developmental plans (Farquhar et al., 2005).

The purpose of this paper is to examine remotely sensed data in order to find relationships between tourism demand and economic growth on Aruba, a small island state, and the environmental response, namely vegetation density. Vegetation is defined as an assemblage of plant species and the ground cover they provide (Burrows, 1990). A common way to identify the response of vegetation to climate or human-induced impacts is to use a satellite-derived vegetation index. A prevalent vegetation index is the normalized difference vegetation index (NDVI) (Wang, Price \& Rich, 2001). Notably, the time series of NDVI data derived from the National Oceanic and Atmospheric Administration (NOAA) satellite has been broadly used to identify vegetation movement due to their relatively long coverage period (Bao, Zhou, Li, \& Sanjjav, 2014). Results from this study will gauge the effective use of remotely sensed data for the achieving of sustainable tourism development on a small island state. The methodology involves using an Autoregressive Distributed Lag Model (ARDL) approach to test cointegration, with subsequent application of Vector Error Correction (VEC) or Vector Autoregressive (VAR) models to test causality among the three constructs. A literature review shows that only a 
few numbers of studies were conducted using the NDVI to monitor density fluctuations in vegetation due to tourism growth on small island states. Therefore, there is a case for better understanding the response of the environment using remote sensing on small island states due to unsustainable tourism development. This study accesses a small island destination, Aruba, as the case study. Other studies have shown possible contributions of individual case studies to scientific generalizations through replication, where the mode is an analytic generalization (Yin, 2009). The goal is then to grow and generalize theories, and not to enumerate frequencies (statistical generalizations). Constructing theory from case studies is a research strategy that involves at least one case to create theoretical constructs, propositions, and/or mid-range theory from case-based empirical (Eisenhardt \& Graebner, 2007).

The rest of this paper is organized as follows. Section 5.2 discusses material and methods. In section 5.3, results and discussion are presented, whereas section 5.4 concludes and offers policy implications and lines for future research.

\subsection{Material and Methods}

\subsubsection{Normalized Difference Vegetation Index (NDVI)}

NDVI is a numerical value that makes use of the visible and near-infrared bands of the electromagnetic spectrum and is adopted to analyze remote sensing measurements and assess whether the target being observed contains live green vegetation or not. NDVI is calculated as NDVI $=(\mathrm{NIR}-\mathrm{VIS}) /(\mathrm{NIR}$ + VIS), where NIR is near-infrared light and (VIS) visible light (Li, Kuang, Huang, \& Zhang, 2013). Usually, healthy vegetation will absorb most of the visible light that falls on it and reflects large portions of the near-infrared light. On the other hand, unhealthy or sparse vegetation reflects more visible light and less near-infrared light. Bare soils will reflect moderately in both the red and infrared portion of the electromagnetic spectrum (Holm, Burnside, \& 
Mitchell, 1987). Calculations of NDVI range from minus one (-1) to plus one $(+1)$. No vegetation gives a value close to zero. Values close to $+1(0.8-0.9)$ indicate the highest possible density of green leaves (USGS, 2014). NDVI has found a wide application in vegetative studies. Some studies have analyzed the relationship between the North Atlantic Oscillation (NAO) atmospheric mode and vegetation activity (NDVI) in the southwest and northeast Europe (Gouveia et al., 2008). They showed that the behavior of vegetation reflects the different responses of surface climate to large-scale atmospheric variability associated with the NAO mode. Other authors have taken several cities in Guangdong Province, China, as study areas to assess the long-term relationship between population growth and vegetation cover, using NDVI and the panel cointegrated regression method ( $\mathrm{Li}$ et al., 2013). Their results indicated that there is a long-term inverted $\mathrm{N}$-shaped curve relationship between population growth and vegetation cover in the region where there are numerous human activities, and the influence of climate change on vegetation cover changes is relatively small. Their results further showed that not only will the consuming destruction effect and planting construction effect caused by the population growth have a significant impact on vegetation cover changes, but vegetation cover fluctuations will also influence the population growth in the long term. NDVI was also used to analyze the vegetation response to rainfall supply in semi-arid regions of Africa (Martiny, Camberlin, Richard, \& Philippon, 2006). They found that mean annual rain-use efficiency was the highest in Southern Africa. In both Southern, Eastern, and Western Africa, the correlation between rainfall and NDVI regimes was found to be significantly high. Kaufmann, Paletta, Tian, Myneni, and D'Arrigo (2008), looked into the causal relationship between NDVI and $\mathrm{CO}_{2}$. The authors were able to identify regions where and months when disturbances to the terrestrial biota "granger cause" atmospheric $\mathrm{CO}_{2}$. The authors were also able to find areas where and months when disturbances to the atmospheric concentration $\mathrm{CO}_{2}$ generate changes in NDVI. 


\subsubsection{Case Study Aruba}

Aruba is a small island located about $32 \mathrm{~km}$ from the Northern coast of Venezuela and has an area of about $180 \mathrm{~km}^{2}$. The island has a tropical steppe, semiarid hot climate with the wind coming for more than $95 \%$ of the time from the northeast and the southeast direction over Aruba, with an average speed of $7.3 \mathrm{~m} \cdot \mathrm{s}^{-1}$ at 10-meter distance (1981-2010) (Ridderstaat, Oduber, Croes, Nijkamp, \& Martens, 2014). Aruba's average temperature is $27.9^{\circ}$ Celsius while fluctuating from $19.0^{\circ}$ Celsius to $36.5^{\circ}$ Celsius. On average (1981-2010), Aruba receives $471.1 \mathrm{~mm}$ of rain (Departamento Meteorologico Aruba, 2014).

The natural vegetation consists of scrubs bushes, scattered divi-divi trees (Caesalpinia coriaria), and xerophytes. The soil type of Aruba is generally shallow, except for pockets of deeper alluvium and a high percentage of gravel and stones. Agriculture is underdeveloped and limited to a few small gardens for vegetables. Most fresh fruits, vegetables, and other agriculture products are imported (Finkel \& Finkel, 1975).

Aruba has a little more than half a century of experience with the tourism industry. In 1959, Aruba built its first 100-room hotel, modeled after similar ones in Florida and Puerto Rico (Cole \& Razak, 2009). In the early part, the tourism industry played only a small role in the overall economic development of the island, given the dominant position of an oil refinery, the Lago Oil \& Transport Company, Ltd (Ridderstaat et al., 2014). This state changed drastically in 1985, when the oil refinery closed its doors, considerably shocking the Aruban economy (Ridderstaat et al., 2014). This critical situation forced the government to search for a new source of economic activity. The most obvious way was to expand the tourism industry. The number of hotel rooms more than tripled, from 1986 to 2011, where the majority of visitors came by airplane (Ridderstaat et al., 2014). The United States tourist, accounting on average for roughly $63.5 \%$ of all stay-over visitors among 1981-2011, makes the biggest market for Aruba. The Venezuelan 
market is the second largest for the island, accounting on average for about $13 \%$ of all stay-over visitors to the island (Ridderstaat et al., 2014).

\subsubsection{Methodology}

The basis for this study is the conceptual scheme depicted in Figure 5.1, where causality will be investigated between, on one hand, vegetation, and both GDP and tourism demand, on the other hand.

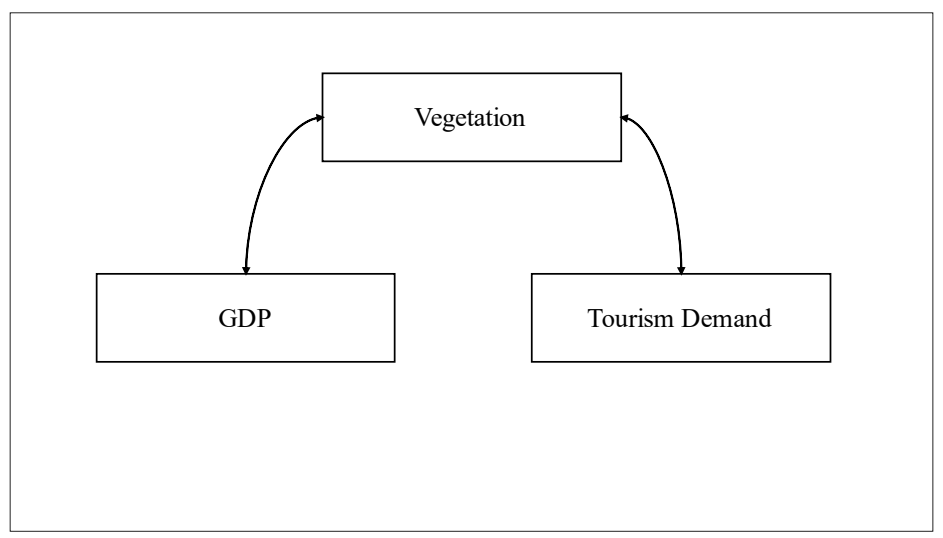

Figure 5.1: Conceptual framework of the relationship among vegetation, GDP and tourism demand.

In order to investigate if the increase in tourism and GDP on Aruba influenced the vegetation, the authors selected two specific areas of the island (Figure 5.2). Area 1 (ARIKOK) is located in the national park in the central part of the island. This area has restrictions on commercial and residential buildings and limited tourist activities and therefore expected to have less influence on tourism and economic development. Area 2 (NOORD) is located at the western part of the island near the high-rise hotels. The western part of Aruba has experienced the highest tourism development and activities since 1986, with most of the available hotel rooms, and restaurants located in that area. 


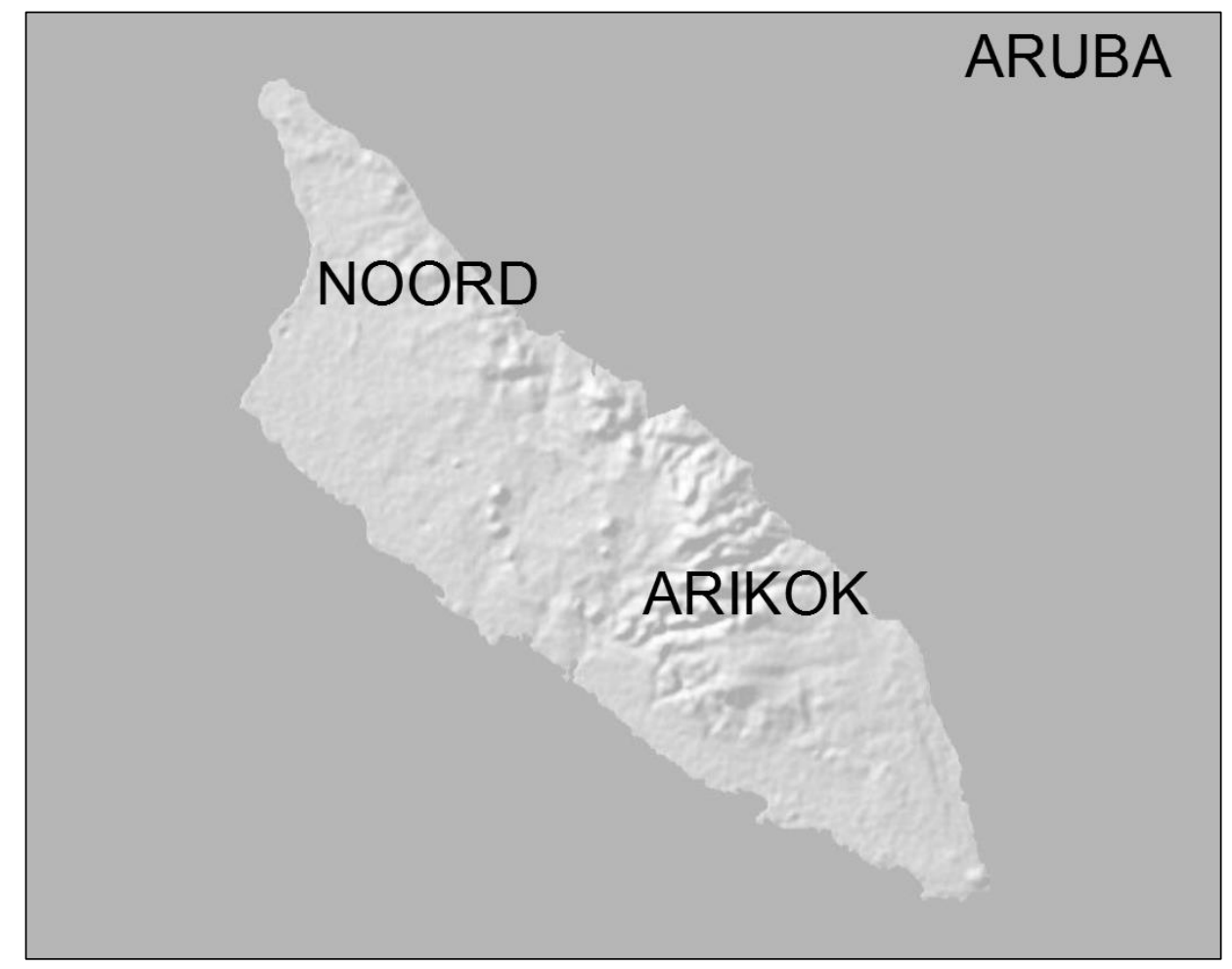

Figure 5.2: Map of points of interest.

NDVI time-series were collected from the Vegetation Index and Phenology (VIP) Lab at the University of Arizona (Lab, 2014). Their vegetation indices are composed of a global Moderate Resolution Imaging Spectroradiometer (MODIS), Advantage Very High-Resolution Spectroradiometer and Satellite Pour l'Observation de la Terre 4 (SPOT4). The VIP lab processed the data into a seamless and sensor independent record using a suite of community algorithms for data filtering, across-sensor continuity, Vegetation Index (NDVI and EVI2), land surface Phenology, and spatial and temporal gap filling. The current version 3.0 is suitable for studies of land surface vegetation dynamics, long term change, and trends, anomalies, and can aid various ecosystem and climate modeling (Didan, 2013). 
Tourism development is proxied by the total number of stay-over visitors (TOUR) for 1981-2010. The economic growth is proxied as the value of all final goods and services produced in Aruba in one year given by the gross domestic product value (GDP). Both TOUR and GDP data are from the Central Bank of Aruba for the period 1981-2010. The data were collected on an annual basis, whereby the series were all transformed to standardize anomalies in order to work simultaneously groups of data that are related but not strictly comparable (Wilks, 1995).

Once the standardized anomalies have been determined, the next step is to assess whether these time series are stationary. This study used the Augmented Dickey-Fuller test (ADF), Phillips-Perron test (PP), and the Kwiatkowski-Phillips-Schmidt-Shin test (KPSS) (Dickey \& Fuller, 1979; Phillips \& Perron, 1988; Kwiatkowski, Phillips, Schmidt, \& Shin, 1992). Studies by Pao, Fu, and Tseng (2012) and Jafari, Othman, and Nor (2012) have shown that the KPSS test is often used as an added value to the ADF and PP tests to get more robust results. Separate from the standard unit root tests, the authors computed the Andrews and Zivot test (Zivot \& Andrews, 1992) and the Clemente, Montanes, and Reyes test (Clemente, Montanes, \& Reyes, 1998). Standard unit root tests can confuse structural breaks and label a stationary variable as a non-stationary time-series. Andrews and Zivot provided a unit root test in the presence of one structural break. The Clemente, Montanes, and Reyes test can handle two structural breaks and can distinguish between additive outliers and innovational outliers. Additive outliers capture sudden changes, while innovational outliers allow for a gradual shift in the mean of the time-series (Geda, 2015).

The tests for stationarity are performed both on the levels and the first differences of the variables. Commonly, the assumption of stationary economic variables can be assumed to hold after differencing these series (Engle \& Granger, 1987). 
Following the test for stationarity, the authors proceeded with an Autoregressive Distributed Lag (ARDL) bounds testing procedure to assess the long-run equilibrium relationship among the constructs. The ARDL model is a general specification, which makes use of the lags of the dependent variable and the lagged and contemporaneous values of the independent variable, through which short-run effects can be estimated directly, and long-run equilibrium relationships can be estimated indirectly. The ARDL has several benefits over other methods of cointegration. First, it can be employed regardless of whether the underlying variables are $\mathrm{I}(0), \mathrm{I}(1)$, or a combination of both. Second, the error correction model (ECM) can be derived from ARDL through a simple linear transformation, which integrates short-run adjustments with long-run equilibrium without losing long-run information. Third, the ARDL approach is more robust and performs better for smaller sample sizes compared to other cointegration techniques (Atif, Jadoon, Zaman, Ismail, and Seemab, 2010). As Pesaran (1999) reveal, the appropriate lags in the ARDL model are corrected for both serial correlation and endogeneity problems. Fourth, the ARDL method can distinguish between dependent and explanatory variables. Dummy variables were used to simulate years that had structural breaks. The ARDL approach involves approximating the following Unrestricted Error Correction Model (UECM) equations.:

$$
\begin{aligned}
& \triangle A R I K O K_{t}=\alpha_{0}+\alpha_{1} A R I K O K_{t-1}+\alpha_{2} T_{O U R} R_{t-1}+\alpha_{3} G D P_{t-1}+ \\
& \sum_{i=1}^{n} \beta_{1 i} \Delta A R I K O K_{t-i}+\sum_{i=1}^{n} \beta_{2 i} \Delta T O U R_{t-i}+\sum_{i=1}^{n} \beta_{3 i} \Delta G D P_{t-i}+ \\
& \text { Dummy }+\varepsilon_{1 t} \\
& \triangle N O O R D_{t}=\alpha_{0}+\alpha_{1} N O O R D_{t-1}+\alpha_{2} \text { TOUR }_{t-1}+\alpha_{3} G D P_{t-1}+ \\
& \sum_{i=1}^{n} \beta_{1 i} \Delta \text { NOORD }_{t-i}+\sum_{i=1}^{n} \beta_{2 i} \Delta \text { TOUR }_{t-i}+\sum_{i=1}^{n} \beta_{3 i} \Delta G D P_{t-i}+ \\
& \text { Dummy }+\varepsilon_{1 t}
\end{aligned}
$$


Where $\Delta$ is the first difference operator, $\alpha$ and $\beta$ are coefficients. The F-test is employed to examine whether a cointegrating relationship exists among the variable. The null hypothesis of no cointegration among the variables for Eq. (1) is $\mathrm{H}_{0}=\alpha_{1}=\alpha_{2}=0$, against $\mathrm{H}_{\mathrm{a}}=\alpha_{1} \neq \alpha_{2} \neq 0$, which is indicated as $F_{\text {ARIKOK }}$ (ARIKOK $\mid$ TOUR, GDP) for Eq. (1). Likewise, for Eq. (2), the null hypothesis of no cointegration among the variables for Eq. (2) is $\mathrm{H}_{0}=\alpha_{1}=\alpha_{2}=0$, against $\mathrm{H}_{\mathrm{a}}=\alpha_{1} \neq \alpha_{2} \neq 0$, which is indicated as $F_{\text {NOORD }}($ NOORD $\mid$ TOUR, GDP) and so on. The F-test has a non-standard distribution, which hinge upon whether variables included in the ARDL model are $\mathrm{I}(0)$ or $\mathrm{I}(1)$; the sum of the regressors whether the ARDL model has an intercept and or a trend and the sample size. Pesaran (1999) and Pesaran, Shin, \& Smith (2001), provided two sets of critical F values for large samples while Narayan (2005) calculated these values for a sample size ranging from 30- 80, where one set assumes that all variable in ARDL model is of type I(1) while the other assumption is that all variables are of type $\mathrm{I}(0)$. If the calculated F-statistics falls beyond the upper critical value, the null hypothesis of no cointegration will be rejected irrespective of whether the values are $\mathrm{I}(0)$ or $\mathrm{I}(1)$. If the value is below the lower value, the null hypothesis of no cointegration cannot be rejected. If the value falls inside the critical value band, inference remains inconclusive, and one should check other cointegration procedures such as the Johansen and Juselius (1990). The ARDL bound test requires prior knowledge of the stationarity of the data series used. The ARDL bound test can only be used for I(0) and I(1) variables. Dantama, Abdullahi, and Inuwa (2012) indicated that the presence of $\mathrm{I}(2)$ variables would invalidate the results of the computed Fstatistics; therefore, all variables need to be $\mathrm{I}(0)$ or $\mathrm{I}(1)$.

Although the ARDL model tests for the existence of or non-existence of long-run relationships among the variables, it does not test for the direction of causality. Therefore, one needs to conduct a VEC to find the causality between the variables if they are integrated of order $1 \mathrm{I}(1)$ ). If the variables are 
not integrated $(\mathrm{I}(0))$, one can proceed with a simple VAR to find the causality among the variables. The Granger causality test will be applied to either the VEC or the VAR depending on the results of the cointegration (Ozturk \& Acaravci, 2013).

\subsection{Results and Discussion}

All estimates were obtained using EVIEWS version 7.2, and Stata version 13. The authors determined the maximum number of lags for the stationarity calculations, following the method proposed by (Schwert, 1989):

$P_{\max }=\operatorname{int}\left[12 x\left(\frac{T}{100}\right)^{\frac{1}{4}}\right]$

Where $P_{\max }$ indicates the maximum number of lags, and $T$ indicates the maximum number of observations. Here, $\mathrm{T}=30$ for all of the variables, and the maximum lag length was therefore established at 8 . Next, the optimal lag within that maximum was determined based on the minimum of the SIC. For almost all the applied variables, the optimal lag length was between 1 and 6 . The optimal lag lengths were subsequently applied in the ADF test. The KPSS and the PP test do not require setting an optimal lag length and could be immediately calculated. Results for the non-structural break stationarity test (ADF, KPSS, and PP) are shown in Table 5.1, results for the Clemente Montanes and Reyes test are shown in Table 5.2, and Table 5.3 gives the results for the Zivot-Andrews test. The summary of all the unit root tests and chosen integration are given in Table 5.4. Given these results, it can be concluded that the series are integrated at different orders, therefore confirming the need for an ARDL bound test. 
Table 5.1: Unit Root Results.

\begin{tabular}{lllll}
\hline Variables & & ADF & PP & KPSS \\
\hline ARIKOK & Level & $-1.282661 * *$ & $-1.348097 * *$ & $0.430038^{*}$ \\
& First Diff. & -5.155952 & -5.534691 & $0.500000^{* *}$ \\
& Integration & $\mathrm{I}(1)$ & $\mathrm{I}(1)$ & $\mathrm{I}(0) / \mathrm{I}(1)$ \\
\multirow{2}{*}{ NOORD } & Level & -2.856945 & -2.863002 & $0.465649^{* *}$ \\
& First Diff. & -8.323637 & -10.03535 & 0.186016 \\
& Integration & $\mathrm{I}(0)$ & $\mathrm{I}(0)$ & $\mathrm{I}(1)$ \\
GDP & Level & $-1.211595 * * *$ & $-0.984471 * * *$ & $0.618686^{* *}$ \\
& First Diff. & -3.062536 & -3.062536 & 0.166244 \\
& Integration & $\mathrm{I}(1)$ & $\mathrm{I}(1)$ & $\mathrm{I}(1)$ \\
TOUR & Level & $-1.178587 * * *$ & $-0.892174 * * *$ & $0.656095^{* *}$ \\
& First Diff. & $-1.167435^{* * *} *$ & -3.043886 & 0.114761 \\
& Integration & $\mathrm{I}(2)$ & $\mathrm{I}(1)$ & $\mathrm{I}(1)$ \\
\hline
\end{tabular}

Note: The symbols $* * *, * *, *$ indicate, respectively, the $1 \%, 5 \%$ and $10 \%$ levels.

Table 5.2: Clemente-Montanes-Reyes unit root tests with two structural breaks.

\begin{tabular}{|c|c|c|c|c|c|c|c|c|}
\hline & \multicolumn{4}{|c|}{ Innovative Outliers } & \multicolumn{4}{|c|}{ Additive Outliers } \\
\hline & t-stat & SB1 & SB2 & Decision & t-stat & SB1 & SB2 & Decision \\
\hline ARIKOK & -7.008 & 1997 & $2002 *$ & $\mathrm{I}(0)$ & -6.270 & $2001 *$ & $2005^{*}$ & $\mathrm{I}(0)$ \\
\hline NOORD & -6.185 & 1987 & $2003^{*}$ & $\mathrm{I}(0)$ & -4.897 & 1985 & $2001 *$ & $\mathrm{I}(1)$ \\
\hline GDP & -3.328 & $1989 *$ & $1995^{*}$ & $\mathrm{I}(1)$ & -4.227 & $1990 *$ & 1996* & $\mathrm{I}(1)$ \\
\hline TOUR & -5.730 & $1987 *$ & $2002 *$ & $\mathrm{I}(0)$ & -3.119 & $1991 *$ & $2005^{*}$ & $\mathrm{I}(1)$ \\
\hline
\end{tabular}

Note: SB1 and SB2 denote the structural break dates suggested by the tests.* indicates that the structural break suggested by the respective test is significant at $5 \%$ level. Critical value at $5 \%$ is -5.490 
Table 5.3: Zivot-Andrews unit root test.

\begin{tabular}{lllll}
\hline & ARIKOK & NOORD & GDP & TOUR \\
\hline Lags included* & 0 & 0 & 1 & 1 \\
$\begin{array}{l}\text { Minimum t- } \\
\text { statistics }\end{array}$ & -5.836 & -5.367 & -3.305 & -4.055 \\
at year & 2004 & 1985 & 1993 & 1990 \\
5\% Critical Value & -4.80 & -4.80 & -4.80 & -4.80 \\
Decision & $\mathrm{I}(0)$ & $\mathrm{I}(0)$ & $\mathrm{I}(1)$ & $\mathrm{I}(1)$ \\
\hline
\end{tabular}

Note: *lags for the difference of the series selected via TTest.

Table 5.4: Summaries of unit root tests.

\begin{tabular}{llllllll}
\hline Variables & $\begin{array}{l}\text { ADF } \\
\text { test }\end{array}$ & $\begin{array}{l}\text { PP } \\
\text { test }\end{array}$ & $\begin{array}{l}\text { KPSS } \\
\text { test }\end{array}$ & $\begin{array}{l}\text { Zivot- } \\
\text { Andrews }\end{array}$ & $\begin{array}{l}\text { Clemente } \\
\text { et al. IO } \\
\text { model }\end{array}$ & $\begin{array}{l}\text { Clemente } \\
\text { et al. AO } \\
\text { model }\end{array}$ & $\begin{array}{l}\text { Final } \\
\text { Decision }\end{array}$ \\
\hline ARIKOK & $\mathrm{I}(1)$ & $\dot{\mathrm{I}}(1)$ & $\dot{\mathrm{I}}(0) / \mathrm{I}(1)$ & $\mathrm{I}(0)$ & $\dot{\mathrm{I}}(0)$ & $\mathrm{I}(0)$ & $\mathrm{I}(0)$ \\
NOORD & $\mathrm{I}(0)$ & $\mathrm{I}(0)$ & $\mathrm{I}(1)$ & $\mathrm{I}(0)$ & $\mathrm{I}(0)$ & $\mathrm{I}(1)$ & $\mathrm{I}(0)$ \\
GDP & $\mathrm{I}(1)$ & $\mathrm{I}(1)$ & $\mathrm{I}(1)$ & $\mathrm{I}(1)$ & $\mathrm{I}(1)$ & $\mathrm{I}(1)$ & $\mathrm{I}(1)$ \\
TOUR & $\mathrm{I}(2)$ & $\mathrm{I}(1)$ & $\mathrm{I}(1)$ & $\mathrm{I}(1)$ & $\mathrm{I}(0)$ & $\mathrm{I}(1)$ & $\mathrm{I}(1)$ \\
\hline
\end{tabular}

Since annual data is used, an initial maximum lag length of 2 is used for the ARDL calculations (Hamuda, Šuliková, Gazda, \& Horváth, 2013). The results of the bounds test for cointegration, together with the critical values, are reported in Table 5.5. The ARDL model was tested for lags 2 and 1. The model was subjected to a serial correlation test, and the lag model with the lowest AIC and SBC values were kept for calculation. The bounds test shows that no cointegration exists in the equation involving ARIKOK, GDP, and TOUR. On the other hand, the bound test showed that for NOORD as dependent variable, there is a long run relation with GDP and TOUR at 95\%. Since the variable NOORD was cointegrated a granger causality test among the variables NOORD, GDP and TOUR, a VEC model was used. Following Asteriou and Hall (2007) the VEC model is defined as follows: 


$$
\begin{aligned}
\Delta \text { NOORD }_{t}= & \sum_{i=1}^{k} \gamma_{1 i} \Delta N O O R D_{t-k} \\
& +\sum_{i=1}^{l} \gamma_{1 i} \Delta G D P_{t-l}+\sum_{i=1}^{m} \gamma_{1 i} \Delta T O U R_{t-m}+\pi E C T_{t-1} \\
& + \text { dummy }+\varepsilon_{1 t}
\end{aligned}
$$

Where,

$\gamma=$ coefficients;

$\mathrm{ECT}=$ error correction term;

$\varepsilon_{1}=$ residual term, the term is independently and normally distributed,

\begin{tabular}{|c|c|c|c|}
\hline $\begin{array}{l}\text { Dependent } \\
\text { variable }\end{array}$ & \multicolumn{2}{|l|}{ Function } & $\begin{array}{l}\text { F- } \\
\text { statistics }\end{array}$ \\
\hline & \multicolumn{2}{|c|}{\begin{tabular}{l|l|l}
$\mathrm{F}_{\text {ARIKOK }}(\mathrm{ARIKOK}$ & TOUR, GDP)
\end{tabular}} & 2.327787 \\
\hline & \multicolumn{2}{|c|}{$\mathrm{F}_{\mathrm{NOORD}}(\mathrm{NOORD} \mid \mathrm{TOUR}, \mathrm{GDP})$} & 4.549567 \\
\hline $\mathrm{N}=2$ & $\mathrm{I}(0)$ & $\mathrm{I}(1)$ & \\
\hline *F-critical a & $5 \%$ level & 3.837 & \\
\hline
\end{tabular}
with zero and mean and constant variance.

Table 5.5: Bounds test for cointegration.

A VEC model will give both long and short-run causality information. The short-term is determined with an F-statistic (Wald test) on the coefficients of TOUR and GDP, and the long-run determined by the sign of the value of the coefficient of the ECT and its significance. The VEC model showed long-term relationship running from tourism demand and GDP towards the NOORD variable. The model further showed that there exist short-run relationships between tourism demand and the variable NOORD (Table 5.6). 
Table 5.6: Causality testing NOORD, GDP, and TOUR.

\begin{tabular}{|c|c|c|c|c|c|c|c|}
\hline $\begin{array}{l}\text { Dependent } \\
\text { variable }\end{array}$ & $\Delta \mathrm{NOORD}(-1)$ & $\Delta \mathrm{NOORD}(-2)$ & $\Delta \mathrm{GDP}(-1)$ & $\Delta \mathrm{GDP}(-2)$ & $\Delta \mathrm{TOUR}(-1)$ & $\Delta \mathrm{TOUR}(-2)$ & $\mathrm{ECT}_{\mathrm{t}}$ \\
\hline & & & & & $\longleftarrow$ & $\longleftarrow$ & $\leftarrow$ \\
\hline$\triangle$ NOORD & 0.060790 & -0.072507 & -1.991593 & -0.517388 & 2.158408 & 2.254072 & -1.215154 \\
\hline$\Delta \mathrm{GDP}$ & 0.000245 & $-9.20 \mathrm{E}-06$ & 0.573032 & -0.101618 & -0.133755 & -0.025764 & 0.018852 \\
\hline$\triangle \mathrm{TOUR}$ & -0.024986 & -0.017851 & 0.262928 & 0.119159 & 0.252303 & -0.332673 & 0.055396 \\
\hline
\end{tabular}


The long term causality could have been expected, since other studies, such as in China, also showed a relationship between GDP and vegetation amount. Han and $\mathrm{Xu}$ (2008), showed that in Chongqing City, China vegetation distribution and growth did not increase steadily nor rapidly, like GDP and population with sustainable increasing trends from 1998 to 2005. Negative correlations were observed in relatively developed areas nearby the center of the city, where rapid economic development and urbanization made vegetation decrease both in distribution and productivity. For the short term, causality running from tourism to the vegetation in the NOORD area, other authors have seen this also in other places. For example, in Australia, direct impacts of recreation and tourism have been noticed due to the clearing of vegetation for infrastructure or damage from trampling, horse riding, mountain biking and off-road vehicles (Pickering \& Hill, 2007). They further noticed that damages to the vegetation are not just restricted to the initial removal of vegetation. Some construction and use of roads and tracks can result in changes to hydrology and soils, including erosion, sedimentation and pollutant runoff in adjacent areas. On Aruba, the causality is most probably explained by the increase in infrastructure and buildings near the hotel area due to tourism. Data from the Central Bureau of Statistics on Aruba shows a marked increase in population from 1991 through 2000 in the area selected as NOORD (Central Bureau of Statistics, 2011). This probably has to do with the development related to tourism in that region. Therefore one would expect more clearing of vegetation for the building of houses. It is mainly an island environment that is the attraction to tourists, but as a paradox, the environmental consequences of what has happened in the name of tourism development has been destructive (Apostolopoulos \& Gayle, 2002). This is mainly for islands that have enthusiastically embraced mass tourism and allowed unbridled bridled hotel development and resort construction. In actuality, these places were the coastal 
and marine environments that have suffered. According to Apostolopoulos and Gayle (2002), inland mountainous interiors have escaped these severe effects since most modern tourist development and infrastructure provision was to a confined narrow coastal zone. Small-island ecosystems, both in the Caribbean and the Pacific, appear to be very prone to overuse and can quickly become overwhelmed by the rapid and uncontrolled growth of tourism, tourism-related related activities, and the modernizing activities that accompany residential development, commercial growth, infrastructure structure expansions (Apostolopoulos \& Gayle, 2002).

Since the variables ARIKOK, GDP, and TOUR were not cointegrated, the authors proceeded with a VAR test in order to find possible short-term causalities. The VAR model is specified as:

$$
\begin{aligned}
A R I K O K_{x t}= & a_{1} A_{R I K O K_{t-1} \ldots .+a_{p} A R I K O K_{t-p}} \\
& +b_{1} G D P_{t-1} \ldots+b_{p} G D P_{t-p} \\
& +c_{p} T O U R_{t-p} \ldots c_{p} T O U R_{t-p}+d u m m y+\mu_{t}
\end{aligned}
$$

Where, $a, b, c=$ coefficients $\mu_{t}=$ uncorrelated white-noise error term.

The VAR model is based on the Toda Yamamoto procedure for the test for granger causality (Toda \& Yamamoto, 1995). They showed that one can calculate VAR's formulated in levels and test general restrictions on the parameter matrices even if the processes may be integrated or cointegrated of an arbitrary order. One can apply a usual lag selection procedure to a possibly integrated or cointegrated VAR since the standard asymptotic theory is valid (Toda \& Yamamoto, 1995). Here, the authors test the null hypothesis on the absence of Granger causality among ARIKOK, GDP, and TOUR. The Toda Yamamoto Granger causality model for ARIKOK showed that there does not 
exist short-term causality among ARIKOK, TOUR, and GDP (Table 5.7). So the model showed that there is no relationship between the vegetation in the central part of Aruba and fluctuations in tourism demand and gross domestic product.

This is in contrast to the variable NOORD and other studies that showed that GDP and tourism could have an impact on the vegetation (Newsome, Moore, \& Dowling, 2012; Spellerberg, 1998). These authors noticed that ecological damage due to tourism is not only limited to the initial removal of native vegetation but other factors also. For example, the construction and use of roads can cause changes to hydrology and soil erosion and pollutant run-off. These studies also noticed that even in protected areas, such as ARIKOK, with no infrastructure change, the tourist practicing backcountry activities can cause vegetation to be crushed, sheared off, and uprooted. These results will cause changes to the vegetation height, biomass, reduction in cover, reproductive structure (Liddle, 1997).

Other studies on plants showed that features of plant morphology could make a plant more resistant to damage (Pickering \& Hill, 2007). Therefore communities dominated by more resistance plants types will be damage at higher use-values compared to areas covered with more sensitive plants. Therefore in some communities/areas, plants can recover faster from induced disturbances than in others. The climatic zone type was also shown to influence the response of vegetation to recreational and tourism use. Aruba has a tropical steppe, hot semiarid climate. It is windy and generally dry, with only 65 days of rain more than $1 \mathrm{~mm}$. Most of the rain falls mainly from October through January (Departamento Meteorologico Aruba, 2014). The climate is a factor in the types of plants on Aruba, where most have to be resistant to drought. Except for the climate of an area, the soil type of the area will also influence the plant types (Boer, 1996). 
Table 5.7: Causality testing ARIKOK, GDP and TOUR.

\begin{tabular}{llllllllll}
\hline Dependent & ARIKOK & ARIKOK & ARIKOK & GDP & GDP & GDP & TOUR & TOUR & TOUR \\
& $(-1)$ & $(-2)$ & $(-3)$ & $(-1)$ & $(-2)$ & $(-3)$ & $(-1)$ & $(-2)$ & $(-3)$ \\
\hline ARIKOK & 0.619 & -0.063 & 0.058 & 0.205 & 0.647 & 0.387 & 0.967 & -2.291 & 0.3036 \\
GDP & -0.058 & 0.110 & -0.088 & 1.234 & -0.689 & 0.037 & 0.270 & -0.204 & 0.357 \\
TOUR & -0.059 & 0.068 & 0.039 & 0.250 & -0.204 & -0.033 & 1.325 & -0.560 & 0.183 \\
\hline
\end{tabular}


The ABC islands, which include Aruba, has mainly a soil consisting of basalt and limestone. The basalt type may contain minerals, but it will not hold water very well. The limestone, on the other hand, can hold water but is deficient in minerals. Another factor that influenced the vegetation on the $\mathrm{ABC}$ islands was the introduction of goats many years ago. Therefore only plants that are capable of deterring the goats would survive and plants resistant to the harsh Aruban climate (Boer, 1996). The area defined as ARIKOK is a protected area with limited development. Tourists can hike or drive vehicles in certain areas. The vegetation in the ARIKOK area would also be considered as highly resistant vegetation that can recover fast. Therefore the authors believe these limitations are the main reason for not seeing any causalities between ARIKOK, GDP, and TOUR. The resistant type plants would recover fast from any damage from the tourist visiting the ARIKOK area. The ARIKOK area falls, also, within the national park zone, limited construction would be allowed, therefore limiting the effect of economic development.

The VEC and VAR models also showed that no long-term relationships were found running from NOORD and ARIKOK variables towards tourism demand. These results indicate that the vegetation density itself does not influence tourism demand. This non-bilateral relationship might have to do also with the reasons why a tourist would visit Aruba. Tourists generally choose Aruba for family-friendly beaches, great weather all year round, safest Caribbean Island, family-friendly hotels, fun-filled activities for kids of all ages, and hassle-free Caribbean Holiday (http://aruba.com). These reasons may help explain the low sensitivity of tourism demand toward vegetation density. The latter is in line with Mendoza-González et al. (2018), who found that tourists prefer warm weather and proximity to the beach. On the other hand, other studies have shown that the number of wildlife tourists are constantly rising in protected areas worldwide, indicating the possibility of 
tourists disliking destinations with less vegetation density (Arbieu, Grünewald, Schleuning, \& Böhning-Gaese, 2017; Balmford et al., 2015).

\subsection{Conclusion}

This study analyzed the relationship between the vegetation index NDVI with tourism demand and economic growth on a small island. The idea was to gauge a bilateral insight between the island vegetation's density, the influence of tourism, and the economic growth of the island. Two areas were selected, one near the hotels and another in the central part of the island. The hotel area showed long-run causality from GDP and tourism towards the vegetation near the hotel areas, and short-run causality from tourism to vegetation near the hotel area. The relationship was explained due to tourism-related related activities, and activities that accompany residential development, commercial growth, infrastructure structure expansions. On the other hand, for the vegetation on the central part, no causality was found between the parameters. This result was explained due to the vegetation type and lack of tourism development in this area. Most of the central part of Aruba falls within the protected national park area. It was also shown in the study that there were no relationships running from vegetation density towards tourism demand, indicating that vegetation denseness did not influence tourism demand.

Some authors have reasoned that to approach a realistic future policy for small islands in the twenty-first century, both the public and private sectors must consider creating limits to tourism growth and expansion (Apostolopoulos \& Gayle, 2002), where they suggest that small islands with limited natural resources and small terrestrial bases would do better-targeting tourism niches and opting for quality over quantity. Some highly capitalized tourist ventures, by their very size and scope, could threaten the fragility of small-island ecosystems in the Pacific and the Caribbean, in large part because their capital power could dominate the local governments, rendering the local government impotent and weakened in resolve to protect their societies landscapes and 
natural habitats (Apostolopoulos \& Gayle, 2002). On Aruba, the authors noticed that the areas were the main hotel developments are did have a relationship with the vegetation in that area. On the other hand, in 1995, the Nature Protection Regulation ordinance became valid on Aruba, therefore making the central part of Aruba a national park. The protection of this area paid off since no relationship with tourism or GDP with vegetation amount in this area were found. Some limitations may apply to this study. The first limitation is that the study was based solely on one destination, mainly Aruba. Secondly, there were no real-time measurements available on the number of buildings built in the hotel areas; the amount was measured indirectly and assuming that more tourists would mean more housing and business development.

Future research should include a database based on aerial pictures and measurements of plant types. Since there might be a possibility that future NDVI measurements might be camouflaged by plants imported by the hotels and business development projects, while indigenous plants itself would be lost. Future research should also focus on the possibility that economic developments itself could have introduced harmful plant diseases and, therefore, worsening the effect of plant loss. 


\section{References}

Arbieu, U., Grünewald, C., Schleuning, M., \& Böhning-Gaese, K. (2017). The importance of vegetation density for tourists' wildlife viewing experience and satisfaction in African savannah ecosystems. PloS one, 12(9).

Apostolopoulos, Y., \& Gayle, D. J. (2002). Island tourism and sustainable development: Caribbean, Pacific, and Mediterranean experiences. Greenwood Publishing Group.

Atif, R. M., Jadoon, A., Zaman, K., Ismail, A., \& Seemab, R. (2010). Trade liberalization, financial development and economic growth: Evidence from Pakistan (1980-2009). Journal of International Academic Research, 10(2), 30-37.

Asteriou, D., \& Hall, S. G. (2007). Applied Econometrics: a modern approach, revised edition. Hampshire: Palgrave Macmillan, 46(2), 117-155.

Balmford, A., Green, J. M., Anderson, M., Beresford, J., Huang, C., Naidoo, R., ... \& Manica, A. (2015). Walk on the wild side: estimating the global magnitude of visits to protected areas. PLoS Biol, 13(2), e1002074.

Bao, Y., Zhou, Y., Li, W., \& Sanjjav, A. (2014). NDVI-based long-term vegetation dynamics and its response to climatic change in the Mongolian Plateau. Remote Sensing, 6(9), 8337-8358.

Boer, B. (1996). Our Plants and trees. Dieren Bescherming Curacao.

Burrows, C. J. (1990). Processes of vegetation change. In Processes of Vegetation Change (pp. 359-419). Springer, Dordrecht.

Caribbean Tourism Organization. (2011).

Caribbean Tourism- State of the Industry 2011. Retrieved from http://www.onecaribbean.org/.

Central Bureau of Statistics. (2011). Retrieved 2014 06-05 from Central Bureau of Statistics Aruba: (http://www.cbs.aw).

Clemente, J., Montanes, A., \& Reyes, M. (1998). Testing for a unit root in variables with a double change in the mean. Economics Letters.

Cole, S., \& Razak, V. (2009). How far, and how fast? Population, culture, and carrying capacity in Aruba. Futures, 41(6), 414-425.

Dantama, Y. U., Abdullahi, Y. Z., \& Inuwa, N. (2012). Energy consumptioneconomic growth nexus in Nigeria: An empirical assessment based on ARDL bound test approach. European Scientific Journal, 8(12).

Departamento Meteorologico Aruba. (2014). Retrieved 2012 22-01 from http://www.meteo.aw.

Dickey, D. A., \& Fuller, W. A. (1979). Distribution of the estimators for Autoregressive time series with a unit root. Journal of the American statistical association, 74(366a), 427-431. 
Didan, K., Barreto-munoz, A., Miura, T., \& Tsend-Ayush, J. (2013, December). A 30-Year Multi-Sensor Vegetation Index and Land Surface Phenology Data Record: Methods Challenges and Potentials. In AGU Fall Meeting Abstracts.

Eisenhardt, K. M., \& Graebner, M. E. (2007). Theory building from cases: Opportunities and challenges. Academy of management journal, 50(1), 25-32.

Engle, R. F., \& Granger, C. W. (1987). Co-integration and error correction: representation, estimation, and testing. Econometrica: journal of the Econometric Society, 251-276.

Farquhar, C. R., Clayton, C. R., \& Retalis, Adrianos (2005). A Satellite Remote Sensing to Aid Sustainable Development: A Case Study of Skiathos Island, Greece. In WSEAS/IASME International Conference on Energy, Environment, Ecosystems and Sustainable Development (pp. 1-6).

Finkel \& Finkel, C. (1975). Water Resources Development Program.

Geda, A. (2015). Applied Time Series Econometrics: a practical guide for macroeconomic researchers with a focus on Africa. University of Nairobi Press.

Gouveia, C., Trigo, R. M., DaCamara, C. C., Libonati, R., \& Pereira, J. M. (2008). The North Atlantic oscillation and European vegetation dynamics. International Journal of Climatology: A Journal of the Royal Meteorological Society, 28(14), 1835-1847.

Hamuda, A. M., Šuliková, V., Gazda, V., \& Horváth, D. (2013). ARDL investment model of Tunisia. Theoretical \& Applied Economics, 20(2).

Han, G. F., \& Xu, J. H. (2008). Influence of population and economic development on vegetation-a case study in Chongqing city. 長江流域 資源與環境, 785-792.

Holm, A. M., Burnside, D. G., \& Mitchell, A. A. (1987). The development of a system for monitoring trend in range condition in the arid shrublands of Western Australia. The Rangeland Journal, 9(1), 14-20.

Jafari, Y., Othman, J., \& Nor, A. H. S. M. (2012). Energy consumption, economic growth and environmental pollutants in Indonesia. Journal of Policy Modeling, 34(6), 879-889.

Johansen, S., \& Juselius, K. (1990). Maximum likelihood estimation and inference on cointegration - with applications to the demand for money. Oxford Bulletin of Economics and statistics, 52(2), 169-210.

Kwiatkowski, D., Phillips, P. C., Schmidt, P., \& Shin, Y. (1992). Testing the null hypothesis of stationarity against the alternative of a unit root. Journal of econometrics, 54(1-3), 159-178.

Kaufmann, R. K., Paletta, L. F., Tian, H. Q., Myneni, R. B., \& D’Arrigo, R. D. (2008). The power of monitoring stations and a CO2 fertilization effect: evidence from causal relationships between NDVI and carbon dioxide. Earth Interactions, 12(9), 1-23. 
Lab, V. I. (2014). The VIP Research Lab. Retrieved from http://vip.arizona.edu/.

Li, C., Kuang, Y., Huang, N., \& Zhang, C. (2013). The long-term relationship between population growth and vegetation cover: An empirical analysis based on the panel data of 21 cities in Guangdong province, China. International journal of environmental research and public health, 10(2), 660-677.

Liddle, M. (1997). Recreation ecology: the ecological impact of outdoor recreation and ecotourism. Chapman \& Hall Ltd.

Martiny, N., Camberlin, P., Richard, Y., \& Philippon, N. (2006). Compared regimes of NDVI and rainfall in semi-arid regions of Africa.

International Journal of Remote Sensing, 27(23), 5201-5223.

Mendoza-González, G., Martínez, M. L., Guevara, R., Pérez-Maqueo, O., Garza-Lagler, M. C., \& Howard, A. (2018). Towards a sustainable sun, sea, and sand tourism: The value of ocean view and proximity to the coast. Sustainability, 10(4), 1012.

Narayan, P. K. (2005). The saving and investment nexus for China: evidence from cointegration tests. Applied economics, 37(17), 1979-1990.

Newsome, D., Moore, S. A., \& Dowling, R. K. (2012). Natural area tourism: Ecology, impacts and management (Vol. 58). Channel view publications.

Ozturk, I., \& Acaravci, A. (2013). The long-run and causal analysis of energy, growth, openness and financial development on carbon emissions in Turkey. Energy Economics, 262-267.

Pao, H. T., Fu, H. C., \& Tseng, C. L. (2012). Forecasting of CO2 emissions, energy consumption and economic growth in China using an improved grey model. Energy, 40(1), 400-409.

Pesaran M. H., a. S. (1999). An autoregressive distributed lag modeling. Chapter 11 in Econometrics and Economic Theory in the $20^{\text {th }}$ Century: The Ragnar Frisch Centennial Symposium, Strom S (ed.). Cambridge University Press: Cambridge.

Pesaran, M. H., Shin, Y., \& Smith, R. J. (2001). Bounds testing approaches to the analysis of level relationships. Journal of applied econometrics, 16(3), 289-326.

Phillips, P. C., \& Perron, P. (1988). Testing for a unit root in time series regression. Biometrika, 75(2), 335-346.

Pickering, C. M., \& Hill, W. (2007). Impacts of recreation and tourism on plant biodiversity and vegetation in protected areas in Australia. Journal of Environmental Management, 791-800.

Ridderstaat, J., Oduber, M., Croes, R., Nijkamp, P., \& Martens, P. (2014). Impacts of seasonal patterns of climate on recurrent fluctuations in tourism demand: Evidence from Aruba. Tourism Management, 41, 245-256. 
Schwert, G. (1989). Tests for Unit Roots: A Monte Carlo Investigation. Journal of Business and Economic Statistics, 2, 147-159.

Spellerberg, I. A. N. (1998). Ecological effects of roads and traffic: a literature review. Global Ecology \& Biogeography Letters, 7(5), 317-333.

Toda, H. Y., \& Yamamoto, T. (1995). Statistical inference in vector autoregressions with possibly integrated processes. Journal of econometrics, 225-250.

UNEP. (2012). The fifth Global Environment Outlook, GEO-5. Valletta: Progress Print LTD.

USGS. (2014). Remote Sensing Phenology. Retrieved from http://phenology.cr.usgs.gov/ndvi_foundation.php.

Wang, J., Price, K. P., \& Rich, P. M. (2001). Spatial patterns of NDVI in response to precipitation and temperature in the central Great Plains. International Journal of Remote Sensing, 22(18), 3827-3844.

Wilks, D. S. (1995). Statistical methods in the atmospheric sciences. Academic Press.

Yin, R. K. (2009). Case study research: Design and methods (4th ed.). Sage Publications, Inc.

Zivot, E., \& Andrews, D. W. K. (2002). Further evidence on the great crash, the oil-price shock, and the unit-root hypothesis. Journal of business \& economic statistics, 20(1), 25-44. 



\section{Conclusion}

\subsection{Study Overview}

Travel \& Tourism, as one of the world's largest economic sectors, creates jobs, stimulates exports, and generates wealth around the world. The World Travel $\&$ Tourism Council (WTTC) indicates that for the Caribbean, the sector accounted for $15.5 \%$ of the GDP and 2.4 million jobs (13.5\% of total employment), and for Aruba $98.3 \%$ of the GDP and 46,900 jobs (99.1\% of total employment) (WTTC, 2019). Given the importance of tourism for the economic and development potential of the region, the main questions for regional decision-makers are: What factors drive demand in the region (Lorde, Li, \& Airey, 2016)?

Tourism moves people from one place to another and has cultural and environmental interfaces, which can lead to new and better situations, or it can harm both parties. This study examined the effects of several economic and natural factors that impact tourism demand, both in the short- and long-run, using the island of Aruba as a case study. The development of tourism presents a dynamic pattern over time, given the full range of human interactions and acts of nature that can cause tourism demand to deviate from its stable trajectory (Baggio, 2008). The case study approach allows the investigation to contribute to the literature through the formulation of new ideas and theoretical proposals (Smith, 2010; Veal, 2006; Yin, 2014).

Essentially, the investigation was divided into three parts. The first section examined in more detail the possible relations between temporal climate fluctuations and tourism demand. Chapter 2 examined the impact of seasonal climate patterns on recurring fluctuations in tourism demand, while Chapter 3 assessed the effects of cyclical climate patterns on fluctuations in tourism demand. The second section examined a possible link between an infectious disease (dengue) and its impact on the local population and tourism as a result of seasonal fluctuations in the flow of tourists to a SID. Chapter 4, in 
this section, investigated the bilateral relationship between tourism and dengue occurrences. The third section was dedicated to studying land-use change, i.e., the gradient change of vegetation due to economic and tourism development. Specifically, the relationship between land use and conversion due to tourism development and economic growth was investigated in Chapter 5. The main empirical findings of the studies in Chapters 2-5 are given hereafter, together with their impact on the hypotheses presented in Chapter 1.

\subsection{Hypothesis Validations}

This study described a series of hypotheses in Chapter 1, which the investigation tested in Chapters 2 - 5. This paragraph addresses these hypotheses in the context of the empirical findings from the studies in the mentioned chapters.

$H_{1}$ : Seasonal climate elements in Aruba, the United States, and Venezuela, respectively, are essential in determining the seasonal variations of tourism demand from the United States and Venezuela.

The investigation in Chapter 2 ('Impacts of seasonal patterns of climate on recurrent fluctuations in tourism demand: Evidence from Aruba') showed that both pull and push seasonal factors of climate were significant in determining the seasonal variations in tourism demand from the United States and Venezuela. Two theoretical propositions were found: (1) climate is a significant push and pull factor affecting tourism demand, and (2) tourism demand and climate are bounded by intertemporal climate constraints. Therefore, the hypothesis was validated, indicating that seasonal weather fluctuations are relevant in seasonal fluctuations in tourism demand from two countries. 
$H_{2}$ : Cyclic patterns of pull and push climate elements in Aruba, The Netherlands, the United States, and Venezuela affect the cyclical deviations of tourism demand for a small destination like Aruba.

The investigation in Chapter 3 ('Impacts of cyclical patterns of climate on fluctuations in tourism demand: Evidence from Aruba') provided an empirical answer to this hypothesis. The results from this chapter corroborated that both pull and push cyclical climate factors had an influence on tourism demand from the United States, The Netherlands, and Venezuela. The empirical statistical relationship found between cyclical atmospheric variabilities and tourism validated this hypothesis.

$H_{3}$ : The El Nino Southern Oscillation (ENSO) and the North Atlantic Oscillation (NAO), affect the cyclical deviations of tourism demand for Aruba.

The investigation in Chapter 3 also corroborated that two critical modes of climate variability, namely ENSO and NAO, influence tourism demand from the United States and The Netherlands. While the climate variability ENSO influenced tourism demand from the United States and the Netherlands, the NAO only influenced tourism demand from the United States. These results verify the hypothesis.

H4: Seasonal tourism demand has an impact on seasonal dengue occurrences in Aruba.

The results in Chapter 4 ('The Bilateral Relationship Between Tourism and Dengue Occurrence: Evidence from Aruba') showed that there was a connection between tourism demand and dengue occurrence, where cruise 
tourism was found to increase dengue cases in Aruba. Therefore the hypothesis was verified.

$H_{5}$ : Seasonal dengue occurrences have an impact on seasonal tourism demand for Aruba.

The study in Chapter 4 showed that while tourism demand influenced the number of dengue cases on Aruba, the amount on dengue occurrences on themselves did not influence the number of stay-over and cruise visitors to Aruba. Since the relationship was not verified, the hypothesis was rejected.

$H_{6}$ : Tourism demand for Aruba has a long-run impact on vegetation density fluctuations on the island.

The investigation in Chapter 5 ('The Connection of Vegetation with Tourism Development and Economic Growth: A Case Study for Aruba') showed that there were effects observed due to tourism demand on the vegetation health (i.e., land-use change) on Aruba, specifically for the western part of the island. Since a relationship was found, i.e., from tourism demand to vegetation, the hypothesis was accepted.

$H_{7}$ : Vegetation density fluctuations in Aruba have a long-run impact on tourism demand for the island.

The results in Chapter 5 showed that no long-run relationships existed from the vegetation density towards the tourism demand on Aruba, so the observed change in vegetation amount did not have an impact on tourism demand in the studied period. Therefore the hypothesis was rejected since the relationship was unilateral, i.e., from tourism demand to vegetation and not vice versa. 
Table 6.1: Summary of the hypotheses and their validations.

\begin{tabular}{lll}
\hline Hypothesis & $\begin{array}{l}\text { Validation or } \\
\text { rejection }\end{array}$ & Based on an empirical study in
\end{tabular}

$\mathrm{H}_{1}$ : Seasonal climate elements in Aruba, the United States, and Venezuela, respectively, are essential in determining the seasonal variations of tourism demand from the United States and Venezuela.

$\mathrm{H}_{2}$ : Cyclic patterns of pull and push climate elements in Aruba, The Netherlands, the United States, and Venezuela affect the cyclical deviations of tourism demand for a small destination like Aruba.

$\mathrm{H}_{3}$ : The El Nino Southern Oscillation (ENSO) and the North Atlantic Oscillation (NAO), affect the cyclical deviations of tourism demand for Aruba.

$\mathrm{H}_{4}$ : Seasonal tourism demand has an impact on seasonal dengue occurrences in Aruba.

Validated

Chapter 3

$\mathrm{H}_{5}$ : Seasonal dengue occurrences have an impact on seasonal tourism demand for Aruba.

Validated

Chapter 4

H6: Tourism demand for Aruba has a long-run impact on vegetation density fluctuations on the

Rejected

Chapter 4 island.

$\mathrm{H}_{7} \quad$ Vegetation density fluctuations in Aruba have a long-run impact on tourism demand for the island.

Validated

Chapter 5

Rejected

Chapter 5

Table 6.1 summarizes the validation results of the selected hypotheses $\left(\mathrm{H}_{1}\right.$ to $\left.\mathrm{H}_{7}\right)$. While the hypotheses related to climate were fully validated $\left(\mathrm{H}_{1}, \mathrm{H}_{2}\right.$, and $\left.\mathrm{H}_{3}\right)$, those associated with infectious disease $\left(\mathrm{H}_{4}\right.$ and $\left.\mathrm{H}_{5}\right)$ and vegetation fluctuation $\left(\mathrm{H}_{6}\right.$ and $\left.\mathrm{H}_{7}\right)$ were not. On the infectious disease, $\mathrm{H}_{4}$ was validated, while $\mathrm{H}_{5}$ was rejected. Regarding the vegetation study, $\mathrm{H}_{6}$ was validated, while $\mathrm{H}_{7}$ was not validated. 


\subsection{Discussion and reflection}

\subsubsection{Study Questions}

This study presented one central proposition that was tested by validating seven hypotheses in this research.

Proposition: natural factors influence tourism demand for a SID. To verify this proposition, the thesis embarked on answering the following central question:

What is the connection between tourism demand in a SID and natural factors?

For this purpose, the study set out to understand a possible bilateral relationship between tourism demand and natural factors, from the perspective of a SID. Answering this general question required the formulation of four detailed subquestions:

1. What is the connection between tourism demand development and vegetation in a SID?

2. Do cycles of climate affect tourism demand in a SID?

3. Do seasonal factors of climate affect tourism demand in a SID?

4. What is the connection between seasonal factors of tourism demand development and dengue in a SID?

These questions were dealt with in detail in Chapters 2-5 of this dissertation. The most critical discussion of and a reflection on each of these elements are described below, followed by a discussion of possible future research directions. 


\subsubsection{Spatial analysis of urbanization and land-use change in a SID}

The attractiveness of tourism depends on a wide range of resources available in each destination. In addition to 'traditional' tourism services (transport, accommodation, food), there are other aspects, such as the existence of natural resources and cultural facilities or the interaction with local communities, which have an evident influence on tourists' preferences (Romão \& Saito, 2017). Tourism generally produces positive economic results, but its social and environmental impacts are mixed. In Chapter 5, it was shown that relationships were found between the amount of vegetation and the demand for tourism in the vicinity of hotel areas, but not in the neighborhood of the protected area. Tourism should be seen as more than just an economic activity, as it affects the socio-cultural and environmental aspects of most countries, including the case of study, as shown in Chapter 5. The rapid growth of tourism on Aruba, in the last three to four decades, has resulted in increased infrastructure, impacting, among others, a gradient in vegetation. The latter could have a possible impact on the quality of life of residents on Aruba. Vegetated areas generally can make a significant contribution to the quality of human life in urban areas through the relaxed atmosphere, recreational opportunities, regulation of air quality, and the presence of exotic animals and plants in these areas (Sinha, 2019). In the case of Aruba, Cole and Razak (2011) noted that scarcely controlled new hotel and housing construction had rapidly diminished land resources and caused a massive influx of immigrant workers to the island. Considering these developments, the authors proposed a more sustainable path of tourism development, by redirecting tourism development geographically and stylistically in order to protect and promote the island's heritage and prosperity, which are essential for residents' quality of life. Furthermore, tourism demand for Aruba is strongly contingent on the island's nature (which is part of the 
tourism product ${ }^{14}$ ), as tourism is a place-dependent activity that relies on the specificity of its territorial resources, and sustainable harmony with the environment is necessary to keep destinations appealing to tourists (Romão, 2018). Additionally, changes in land use and land cover deserve more attention in land management because of their generally imminent negative impact on the status and integrity of ecosystems (Quintas-Soriano et al. 2016). The unsustainable growth in tourism can be reversed by introducing projects such as the Man and Biosphere program of the $\mathrm{UNESCO}^{15}$. Like many other countries, Aruba has also initiated the implementation and localization of the United Nations' goals for sustainable development to measure the progress that contributes to the overall well-being of its citizens ${ }^{16}$.

\subsubsection{Do oscillations in climate influence tourism demand.}

Climate is of particular importance for the tourism sector, as it can cause seasonal and cyclical fluctuations in tourism demand for destinations (Saverimuttu \& Varua, 2014; Otero-Giráldez, Álvarez-Díaz, \& GonzálezGómez, 2012). It could be an even more significant determinant of tourism demand than some common economic factors, such as income, relative prices, and trade (Goh, Law, \& Mok 2008; Li et al. 2018). The studies presented in

${ }^{14}$ According to Polaszek, Lacle, Beukering, \& Wolfs (2018), the total value of tourism expenditure that can be related to Natural Capital (i.e. the gross annual value of natural capital) is estimated at US\$ 564 million.

${ }^{15}$ Biosphere reserves are places for sustainable development, where the needs of human society and their environment are jointly developed, emphasizing the active role of man as an integral part of the environment in which he lives. They include terrestrial, marine and coastal ecosystems. Biosphere reserves cover broadly the same concept as the concept of quality of life, namely human development and well-being in long-term interaction with the natural environment (Nature Conservation Agency of Latvia, 2019; UNESCO, 2019). The author of this dissertation showed the Minister of Education, Science and Sustainable Development the imbalance in vegetation due to tourism and economic development, and recommended UNESCO's Man and Biosphere program. The Minister agreed on this, and the author had already many meetings with stakeholders and the planning on the implementation of this program is in a very advanced stage.

${ }^{16}$ The SDG roadmap is a document that gives Aruba guidance for the implementation of the Sustainable Development Goals (SDGs) at the national level. The latter has been developed according to the guiding principles of the United Nations Development Group (UNDG), as the SDGs aim to assist countries in their development agenda and set priorities with a focus on improving the quality of life for all citizens and ensuring that no one is left behind (COE, 2019). 
Chapters 2 and 3 found meteorological parameters, influenced tourism demand. When looking at seasonal patterns of pull and push climate parameters on the seasonal fluctuations of tourism demand for Aruba, the study showed several connections. Both pull and push seasonal factors of climate were relevant in determining the seasonal variations of tourism demand from the United States and Venezuela. The results from Chapter 3 showed that tourism was connected to cyclical factors of climate. It was further noticed that ENSO events influenced the tourism demand of the United States and The Netherlands, while the climate index, NAO, only influenced tourism demand from the United States. The results from Chapters 2 and 3 showed that the climate in Aruba is an imperative factor for determining short-term movements in tourism demand. The results are intriguing, as they show that monitoring economic factors alone is not enough when it comes to analyzing short-term determinants of tourism demand.

The study corroborates that tourism is an open system with connections to other systems. Here, climate and/or weather systems have a link to the tourism system, through their impact on tourism demand. These findings concur with other studies that shed light on the open system feature of tourism (e.g., Hall \& Lew, 2009; Mcdonald, 2009), and give validation to the application of the Systems Theory in the context of tourism. As indicated by McKercher (1999), tourism behaves as a chaotic, nonlinear, and nondeterministic system. The results in Chapters 2 and 3 further corroborate the non-linearity of tourism since oscillations stemming from climate will influence tourism demand. So the variables can create deviations from the common pattern of tourism demand, pushing the system into chaos, where the system might be pushed back to its original state or a new one in the future. The latter validates the usefulness of Chaos Theory for the study.

Sustainability is the provision of what is needed to allow something or someone to exist and continue to exist in the future. Nowadays, responsible 
entrepreneurs in the tourism sector not only focus on the financial results but also maximize the positive effects on the social, and environmental resources of the area, the so-called TBL (Cook, Hsu \& Taylor, 2018). In the current study, it is shown that economic factors are not sufficient for modeling tourism demand. Therefore, it seems more complete to take into account climate as an essential determinant of tourism demand; this in order to reach sustainability in tourism in order to guarantee the continuity of the enterprise and the destination in the long-term. Additionally, the links found with NAO and ENSO in the investigation are also interesting. Statistical significance for variables such as the NAO and the ENSO index implies that climatological variables are a relevant factor in explaining tourism demand and that this should be taken into account when drawing up a tourism demand model. The latter is a contribution of this study since the vast majority of the previous research does not take climate and weather conditions into account in their analysis (Álvarez-Díaz, Giráldez \& González-Gómez, 2010). Also, basic knowledge of climatic conditions that have a strong influence on the choice of destination and the satisfaction of the activities is a prerequisite for the development of specialized climate products for the tourism sector (Scott, Lemieux, \& Malone, 2011). The potential of climate/weather information in the tourism sector is enormous, given the large number and diversity of end-users, according to the latter authors. The full-time scale of weather and climate information, from historical to short and medium-term forecasts (1, respectively 7-10 days), longterm forecast (weeks to years) to multi-decadal climate change forecasts, should be used by tourism players and planners in a wide range of decision-making contexts in order to make tourism more sustainable and resilient. In the case of sustainability, the emphasis should be on improving the quality of life for environmental, social, and economic reasons, both for present and future generations. On the other hand, from a resilient perspective, the focus should 
be on the response of systems (including environmental, social, and economic systems) to disturbances (Marchese et al., 2018).

Resilience is the capability of a system to anticipate hazards, absorb effects, recover and adapt after continued stress or a disruptive event (Marchese et al., 2018).

\subsubsection{Do oscillations in vector-borne diseases influence tourism demand on a} SID.

The focus of this study was to investigate the link between tourism demand and dengue occurrence, namely whether the decision to travel to a SID plagued by this infectious disease could be influenced, and whether tourists themselves could introduce dengue to the selected destination. Several studies showed that dengue could affect tourist (e.g., Cobelens et al., 2002; Wichmann, Muhlberger, \& Jelinek, 2003; Schwartz et al., 2008), but there is an absolute lack of studies exploring how dengue affects seasonal fluctuations of tourism demand on SIDs. The findings in Chapter 4 indicate that cruise tourism raises dengue cases in Aruba, while dengue cases themselves had no bearing on the number of stay-over and cruise visitors in Aruba. As was the case with the other presented investigations in this thesis, this study again shows the open system nature of tourism, further validating the Open Systems Theory in the context of this investigation.

The health of the population is the concern of everyone and is more or less related to all the 17 SDGs of the United Nations ${ }^{17}$, mainly because the goals are interconnected, interdependent with one another in order to leave no

17 The objectives for sustainable development are the blueprint for a better and more sustainable future for all. They respond to the global challenges we face, including those related to poverty, inequality, climate change, environmental degradation, peace and justice. The 17 objectives are all interlinked and in order not to leave anyone behind, it is important that we achieve them all by 2030. SDG 1: No Poverty; SDG 2: Zero Hunger; SDG 3: Good Health and Well-being; SDG 4: Quality Education; SDG 5: Gender Equality; SDG 6: Clean Water and Sanitation; SDG 7: Affordable and Clean Energy; SDG 8: Decent Work and Economic Growth; SDG 9: Industry, Innovation and Infrastructure; SDG 10: Reduced Inequality; SDG 11: Sustainable Cities and Communities; SDG 12: Responsible Consumption and 
one behind (Braks, Giglio, Tomassone, Sprong, \& Leslie, 2019). The latter authors showed that an increase in dengue (communicable disease) (SDG 3), is related to trade, travel, urbanization, and climate change (SDG 11, 13). Furthermore, they indicated that the availability of breeding containers is related to socioeconomic status (SDG 10), lack of water (SDG 6), and garbage accumulation (SDG 11). Also, if one starts with an integrated Aedes management program, SDG 12 and SDG 4 will come into play due to the use of chemicals and the task of the local population to take its responsibility through education. SDG 15 can also be linked to Aedes management because the Aedes mosquito can be seen as an invasive species. Chapter 4 showed that cruise tourists could increase dengue on Aruba and the latter, which could jeopardize Aruba's goal of sustainable economic development set by the government (Polaszek, Lacle, Beukering, \& Wolfs, 2018). Dengue disease can also affect employment conditions as health (SDG 3), and employment (SDG 8) are intricately linked. The tourism sector is labor-intensive, relying on the presence of qualified staff to supply, operate, and manage the tourism product (Amoah \& Baum 1997). People in poor health are more likely to be unemployed or underemployed, as ill-health reduces their ability to work, and when they work, ill health reduces their productivity (WHO, 2018). In an unfavorable spiral, this increases the risk of job losses, absenteeism, or early retirement (WHO, 2018). Table 6.2 gives an overview of the most important SDGs and targets concerning the prevention of dengue.

Production; SDG 13: Climate Action; SDG 14: Life Below Water; SDG 15: Life on Land; SDG 16: Peace and Justice Strong Institutions; SDG 17: Partnerships to achieve the Goal. 
Table 6.2: Overview of the most important SDGs and targets concerning the prevention of dengue (from Braks, Giglio, Tomassone, Sprong, \& Leslie, 2019).

\begin{tabular}{|c|c|c|c|c|c|c|c|}
\hline $\begin{array}{l}\text { SDG } 3 \text { Good health } \\
\text { and well-being }\end{array}$ & $\begin{array}{l}\text { SDG 4 Quality } \\
\text { education }\end{array}$ & $\begin{array}{l}\text { SDG 6 Clean } \\
\text { water and } \\
\text { sanitation }\end{array}$ & $\begin{array}{l}\text { SDG } 10 \text { Reduced } \\
\text { inequalities }\end{array}$ & $\begin{array}{l}\text { SDG } 11 \\
\text { Sustainable cities } \\
\text { and communities }\end{array}$ & $\begin{array}{l}\text { SDG12 Responsible } \\
\text { consumption and } \\
\text { production }\end{array}$ & $\begin{array}{l}\text { SDG } 13 \text { Climate } \\
\text { action }\end{array}$ & $\begin{array}{l}\text { SDG } 15 \text { Life on } \\
\text { land }\end{array}$ \\
\hline $\begin{array}{l}3.3 \text { By } 2030 \text {, end } \\
\text { the epidemics of } \\
\text { AIDS, tuberculosis, } \\
\text { malaria and } \\
\text { neglected tropical } \\
\text { diseases and } \\
\text { combat hepatitis, } \\
\text { water-borne } \\
\text { diseases and other } \\
\text { communicable } \\
\text { diseases }\end{array}$ & $\begin{array}{l}4.3 \text { By } 2030, \\
\text { ensure equal } \\
\text { access for all } \\
\text { women and men } \\
\text { to affordable and } \\
\text { quality technical, } \\
\text { vocational and } \\
\text { tertiary } \\
\text { education, } \\
\text { including } \\
\text { university }\end{array}$ & $\begin{array}{l}6.1 \text { By } 2030 \text {, } \\
\text { achieve universal } \\
\text { and equitable } \\
\text { access to safe and } \\
\text { affordable } \\
\text { drinking water } \\
\text { for all }\end{array}$ & $\begin{array}{l}10.1 \text { By } 2030, \\
\text { progressively } \\
\text { achieve and } \\
\text { sustain income } \\
\text { growth of the } \\
\text { bottom } 40 \text { per cent } \\
\text { of the population } \\
\text { at a rate higher } \\
\text { than the national } \\
\text { average }\end{array}$ & $\begin{array}{l}11.6 \text { By } 2030, \\
\text { reduce the adverse } \\
\text { per capita } \\
\text { environmental } \\
\text { impact of cities, } \\
\text { including by } \\
\text { paying special } \\
\text { attention to air } \\
\text { quality and } \\
\text { municipal and } \\
\text { other waste } \\
\text { management }\end{array}$ & $\begin{array}{l}12.4 \text { By } 2020, \\
\text { achieve the } \\
\text { environmentally } \\
\text { sound management } \\
\text { of chemicals and all } \\
\text { wastes throughout } \\
\text { their life cycle, in } \\
\text { accordance with } \\
\text { agreed international } \\
\text { frameworks, and } \\
\text { significantly reduce } \\
\text { their release to air, } \\
\text { water and soil in } \\
\text { order to minimize } \\
\text { their adverse } \\
\text { impacts on human } \\
\text { health and the } \\
\text { environment }\end{array}$ & $\begin{array}{l}\text { 13.1 Strengthen } \\
\text { resilience and } \\
\text { adaptive capacity } \\
\text { to climate-related } \\
\text { hazards and } \\
\text { natural disasters } \\
\text { in all countries }\end{array}$ & $\begin{array}{l}15.8 \text { By } 2020, \\
\text { introduce } \\
\text { measures to } \\
\text { prevent the } \\
\text { introduction and } \\
\text { significantly } \\
\text { reduce the impact } \\
\text { of invasive alien } \\
\text { species on land } \\
\text { and water } \\
\text { ecosystems and } \\
\text { control or } \\
\text { eradicate the } \\
\text { priority species }\end{array}$ \\
\hline $\begin{array}{l}\text { 3.d Strengthen the } \\
\text { capacity of all } \\
\text { countries, in } \\
\text { particular } \\
\text { developing } \\
\text { countries, for early } \\
\text { warning, risk } \\
\text { reduction and } \\
\text { management of } \\
\text { national and global } \\
\text { health risks }\end{array}$ & & & & & & & \\
\hline
\end{tabular}


Dengue is a threat to more than 390 million people, and its resurgence has become one of the most pressing global health threats (WHO, 2019a). However, the recent spread of other infectious diseases by the chikungunya and the zika virus around the world also indicates the resurgence of mosquito-borne diseases. The increase in these vector-borne diseases is probably the result of increasing trade and travel, as well as continuous and progressive urbanization, and perhaps climate change (WHO, 2019b), and since no effective vaccine or medicine is still available to prevent or cure chikungunya, and zika, disease

prevention by vector managing remains a critical component of disease control, even though it is a challenging effort (Paixão, Teixeira, \& Rodrigues, 2018).

\subsection{Theoretical implications}

The main focus of this study was the connection between tourism demand in a SID and natural factors. From the study, a few theoretical implications can be inferred. First, the climate is the most important natural factor affecting tourism demand as its effect is time- and motivation-variant (pull and push). These dimensions could produce a series of combinations under which climate can impact tourism demand for destinations. Second, the relationship between dengue occurrence and tourism demand could be bilateral and dependent on the type of tourist (stay-over or cruise tourism) that a destination entertains. This has implications for the level of risk of infectious disease destination experiences, and the cause/effect relationship with its tourism industry. Third, tourism demand and vegetation could have a symbiotic relationship, as the development of one can have implications for the other, and vice versa.

Looking at the results of the studies and their relationships with the methodological theories, the following relationships and connections were found. The climate studies being seasonal and cyclical had two relationships with the methodology. First, the cyclical study showed that ENSO or NAO influences tourism demand, so a parameter that does not repeat itself on precise known intervals will influence tourism. Here, as with the butterfly effect, a 
smaller event causes a disturbance of stability and can amplify the disturbance in such a way as to jeopardize the integrity and cohesion of tourism continuity. Secondly, the climate studies have shown that several climate variables influence the tourism demand variable. This fits in the methodological approach that tourism is an open system. Moreover, in order to achieve sustainability in tourism and thus ensure the long-term continuity of the enterprise and the destination, it is demonstrated that stakeholders need to take climate into account as key determinants of tourism demand. These results were explained in more detail in Chapter 6.3.

Regarding the health study, it was shown that cruise tourists could increase the number of people infected with dengue on a destination. On the other hand, the increase in dengue cases itself had no bearing on the continuity of tourism demand. This study shows the open system nature of tourism and therefore validates the open system theory. On the other hand, since the number of dengue cases did not cause shocks/disturbances in the tourism demand variable, it is shown that for the case study, chaos theory was not applicable. The health study further corroborates the link between sustainability-tourismhealth, as indicated in Chapter 6.3.

For the study on vegetation and its relationship with tourism, it was shown as expected that the sustainable methodological theory would fit it best. The results showed short and long-term effects due to tourism and economic development on the gradient of vegetation near the western part of Aruba, and this can influence the long-run continuity of tourism demand (sustainability) as indicated in Chapter 6.3. 


\subsection{Directions for future research}

This study investigated the relationship between different natural factors and tourist demand for a SID. The study provided new ideas for analyzing the relationship between natural factors and short and long term development in tourism demand. The study also contributed to the theory-building process by providing a number of theoretical implications according to the case studies applied in the individual studies discussed.

Future studies can extend the depth and span of the studied determinants of tourism demand dynamics, and the resulting theoretical implications. For example, more destinations should be included, and the study period should be extended when more data becomes available. In the case of dengue as a study objective, it is also recommended that an integrated assessment model be used on SIDs, which includes evolutionary, spatial, and local dynamics of ecological, environmental, social, demographic, and behavioral factors. In other words, the approach would make it possible to identify potentially critical indirect interactions or mechanisms, identify significant research gaps and find a means of integrating targeted research from different disciplines into a better understanding of the whole system (Chan, Ebi, Smith, Wilson, \& Smith, 1999). As for the study on vegetation amount (i.e., land-use change) and tourism demand, a database, grounded on aerial pictures and measurements of plant types on the target area could provide useful information for study purposes. The latter is because the vegetation index used in the study cannot distinguish between indigenous plants and imported plants. The vegetation study should be seen as an open door for more studies in the detection and spatial analysis of urbanization and land-use change in SIDs, using GIS and remote sensing techniques. For example, remote sensing techniques should be further tested to find urban growth patterns from specific periods to date, with the idea of looking at the drivers and the control 
factors of urban growth. Ultimately, better simulation models can be developed to investigate future land use scenarios in the future.

While not studied in this dissertation, investigating the value that an islander would ascribe to each of the individual dimensions of quality of life, for example, the environmental dimension versus an economic or political dimension, would contribute to advancing the literature and could be important for SIDs. Cole \& Razak, (2011) indicated that, for example, on the island of Aruba there was a difference in segments of society when looking at the issue of carrying capacity of tourism, where migrants were more interested in the economic part (jobs), whereas others were more interested in environmental aspects. This future type of study on quality of life could also benefit policymaking, as governments around the world have an interest in measuring the well-being of its citizens in order to improve their policy decisions (Sinha, 2019). Shocks or disturbances ( e.g., wars, weather, climate, terrorism) can also affect the development of tourism and the quality of life of residents of destinations. A tourism demand model without these external factors can provide an incomplete picture and can either lead to missed opportunities to improve tourism development and quality of life or seriously deepen and/or prolong the adverse effects of the shocks or disruptions (Ridderstaat, 2015).

Also, future studies can dive deeper into other types of infectious diseases and how they affect the different forms of tourism (e.g., stay-over versus cruise tourism), and whether the latter can also contribute to the further spread of these diseases. Tourism demand remains an intuiting constituent of tourism development that is gradually sharing the contours of its bearing. It is up to research to dive into the unnumbered possibilities of driving forces of this phenomenon. 


\section{References}

Álvarez-Díaz, M., Giráldez, M. S. O., \& González-Gómez, M. (2010).

Statistical relationships between the North Atlantic Oscillation and international tourism demand in the Balearic Islands, Spain. Climate Research, 43(3), 207-214.

Amoah, V. A., \& Baum, T. (1997). Tourism education: policy versus practice. International Journal of Contemporary Hospitality Management, 9(1), $5-12$.

Baggio, R. (2008). Symptoms of complexity in a tourism system. Tourism Analysis, 13(1), 1-20.

Braks, M., Giglio, G., Tomassone, L., Sprong, H., \& Leslie, T. (2019). Making Vector-Borne Disease Surveillance Work: New Opportunities From the SDG Perspectives. Frontiers in veterinary science, 232.

Chan, N. Y., Ebi, K. L., Smith, F., Wilson, T. F., \& Smith, A. E. (1999). An integrated assessment framework for climate change and infectious diseases. Environmental health perspectives, 107(5), 329-337.

Cobelens, F. G., Groen, J., Osterhaus, A. D., Leentvaar-Kuipers, A., Wertheimvan Dillen, P. M. \& Kager, P. A. (2002). Incidence and risk factors of probable dengue virus infection among Dutch travellers to Asia. Tropical Medicine and International Health, 7(4), 331-338.

COE, Center of Excellence for Sustainable Development of SIDS (2019). The Aruba SDG Roadmap. Retrieved from http://www.sustainablesids.org/knowledgebase/the-aruba-sdgroadmap.

Cook, R. A., Hsu, C., \& Taylor, L. L. (2018). Tourism: The Business of Hospitality and Travel (What's New in Culinary \& Hospitality).

Cole, S., \& Razak, V. (2011). Island Awash - Sustainability Indicators and Social Complexity in the Caribbean. In M. Budruk, \& P. Rhonda, Quality-of-Life Community Indicators for Parks, Recreation and Tourism Management (pp. 141-161). New York: Springer.

Dwyer, L., Edwards, D., Mistilis, N., Roman, C., \& Scott, N. (2009). Destination and enterprise management for a tourism future. Tourism Management, 30(1), 63-74.

Goh, C., Law, R., \& Mok, H. M. (2008). Analyzing and forecasting tourism demand: A rough sets approach. Journal of Travel Research, 46(3), 327-338.

Hall, C. M., \& Lew, A. A. (2009). Understanding and managing tourism impacts: An integrated approach. Routledge.

Li, H., Goh, C., Hung, K., \& Chen, J. L. (2018). Relative climate index and its effect on seasonal tourism demand. Journal of Travel Research, 57(2), 178-192.

Lorde, T., Li, G., \& Airey, D. (2016). Modeling Caribbean tourism demand: an augmented gravity approach. Journal of Travel Research, 55(7), 946956. 
Marchese, D., Reynolds, E., Bates, M. E., Morgan, H., Clark, S. S., \& Linkov, I. (2018). Resilience and sustainability: Similarities and differences in environmental management applications. Science of the total environment, 613, 1275-1283.

McKercher, B. (1999). A chaos approach to tourism. Tourism management, 20(4), 425-434.

McDonald, J. R. (2009). Complexity science: an alternative world view for understanding sustainable tourism development. Journal of Sustainable Tourism, 17(4), 455-471.

Nature Conservation Agency of Latvia. (2019). Nature Conservation of Latvia. Retrieved from Nature Conservation Agency of Latvia website: https://www.daba.gov.lv/upload/File/PP17/KonfZBR20_17130_ TKokovkin_Estonia_expierence.pdf.

Otero-Giráldez, M., Álvarez-Díaz, M., \& González-Gómez, M. (2012).

Estimating the long-run effects of socioeconomic and meteorological factors. Tourism Management, 1301-1308.

Paixão, E. S., Teixeira, M. G., \& Rodrigues, L. C. (2018). Zika, chikungunya and dengue: the causes and threats of new and re-emerging arboviral diseases. BMJ global health, 3(Suppl 1), e000530.

Polaszek, T., Lacle, F., Beukering, van, P., \& Wolfs, E. (2018). TEEB ArubaThe Economics of Ecosystems and Biodiversity. Wolfs Company.

Quintas-Soriano, C., Castro, A. J., Castro, H., \& Garc1'a-Llorente, M. (2016). Impacts of land use change on ecosystem services and implications for human well-being in Spanish drylands. Land Use Policy, 54, 534-548.

Ridderstaat, J. (2015). Studies on Determinants of Tourism Demand: Dynamics in a Small Island Destination. The Case of Aruba.

Romão, J., \& Saito, H. (2017). A spatial analysis on the determinants of tourism performance in Japanese Prefectures. Asia-Pacific Journal of Regional Science, 1(1), 243-264.

Romão, J. (2018). Tourism, territory and sustainable development. Springer Nature Singapore.

Saverimuttu, V., \& Varua, M. E. (2014). Climate variability in the origin countries as a "push" factor on tourist arrivals in the Philippines. Asia Pacific Journal of Tourism Research, 19(7), 846-857.

Scott, D., Lemieux, C., \& Malone, L. (2011). Climate services to support sustainable tourism and adaptation to climate change. Climate Research, 111-122.

Sinha, B. (2019). Multidimensional Approach to Quality of Life Issues: A Spatial Analysis. Singapore: Springer.

Smith, S. L. (2010). Practical tourism research. Cabi, United Kingdom.

Stoddard, J. E., Pollard, C. E., \& Evans, M. R. (2012). The triple bottom line: A framework for sustainable tourism development. International Journal of Hospitality \& Tourism Administration, 13(3), 233-258. 
Schwartz, E., Weld, L. H., Wilder-Smith, A., von Sonnenburg, F., Keystone, J.S., Kain, K. C.,\& GeoSentinel Surveillance Network. (2008). Seasonality, annual trends, and characteristics of dengue among ill returned travelers, 1997-2006. Emerging Infectious Diseases, 14(7), 1081-1088.

Veal, A. (2006). Research methods for leisure and tourism: A practical guide. Pearson Education Limited, England.

UNESCO. (2019). Ecological Sciences for Sustainable Development. Retrieved 12 2, 2019, from

http://www.unesco.org/new/en/naturalsciences/environment/ecologicasciences/biosphere-reserves/.

UNWTO. (1999). Global code of ethics for tourism. UNWTO, Madrid, Spain.

UNWTO. (2011). Tourism Towards 2030, Global Overview. UNWTO, Madrid, Spain.

Wichmann, O., Muhlberger, N., \& Jelinek, T. (2003). Dengue-The underestimated risk in travellers. Dengue Bulletin, 27, 126-137.

WHO. (2018). SDG8: Health, decent work, and the economy. Retrieved 12 30, 2018, from

http://www.euro.who.int/en/health-topics/health-policy/sustainable development-goals/publications/2019/policy-briefs-on-health-and-the sustainable-development-goals/sdg-8-health,-decent-work-and-the economy.

WHO. (2019a). Dengue and Severe Dengue [Online]. Retrieved 12 2, 2019, from World Health Organization:

https://www.who.int/news-room/fact-sheets/.

WHO. (2019b). Vector-borne diseases [Online]. Retrieved 12 2, 2019, from

World Health Organization:

https://www.who.int/news-room/fact-sheets/detail/vector-borne diseases.

WTTC. (2019). Country Data World Travel \& Tourism Council (WTTC). Retrieved 9 26, 2019, from WTTC:

https://www.wttc.org/economic-impact/country-analysis/country-data/.

Yin, R. K. (2014). Case study research: Design and methods (applied social research methods). Thousand Oaks, CA: Sage publications. 


\section{List of abbreviations}

$\mathrm{ABC}$

ADF

AIC

$\mathrm{ARCH}$

ARDL

AUARAIN

AUATEMP

AUAWIND

AUA_CLOUD

AUA_DENGUE

AUA_MAX

AUA_MIN

AUA_RAIN

AUA_RH

AUA_TEMP

AUA_WIND
Aruba Bonaire Curaçao

Augmented Dickey-Fuller test

Akaike information

Autoregressive Conditional Heteroskedasticity

Autoregressive Distributed Lag Model

Aruba Rainfall Data

Aruba Average Temperature Data

Aruba Windspeed Data

Aruba Cloud Coverage

Aruba Suspected Dengue Cases

Aruba Average Maximum Temperature Data

Aruba Average Maximum Temperature Data

Aruba Rainfall Data

Aruba Relative Humidity

Aruba Average Temperature Data

Aruba Windspeed Data 


\begin{tabular}{|c|c|}
\hline BCE & Before Common Era \\
\hline $\mathrm{C}$ & Cycle \\
\hline CAUA & Cloud Coverage in Aruba \\
\hline CDC & Centers for Disease Control and Prevention \\
\hline $\mathrm{CPC}$ & Climate Prediction Center \\
\hline CRUISE_TOUR & Cruise Tourism Demand \\
\hline ECMWF & $\begin{array}{l}\text { European Centre for Medium-Range Weather } \\
\text { Forecasts }\end{array}$ \\
\hline EDM & Euclidean distance measure \\
\hline EVI & Enhanced vegetation index \\
\hline ENSO & El Nino Southern Oscillation \\
\hline FEM & Fixed effects model \\
\hline GDP & Gross domestic product value \\
\hline GIS & Geographic Information System \\
\hline HOLRAIN & Holland Rainfall Data \\
\hline HOLTEMP & Holland Temperature Data \\
\hline HOLTOUR & Holland (The Netherlands) Tourism Demand \\
\hline HOLWIND & Holland Windspeed Data \\
\hline
\end{tabular}


Integrated

IR

Irregular elements

KPSS Kwiatkowski-Phillips-Schmidt-Shin test

LM

Lagrange Multiplier

MEI

Multivariate ENSO index

MODIS

MODerate resolution Imaging Spectroradiometer

NAO

The North Atlantic Oscillation

NCAR

National Center for Atmospheric Research

NCEP

National Centers for Environmental Prediction

NDVI

Normalized difference vegetation index

NIR

NOAA

National Oceanic and Atmospheric Administration

OLS

Ordinary Least Squares

PAHO

Pan American Health Organization

PP

Phillips-Perron test

RAUA

Rainfall in Aruba

REM

Random effects model 
RCO

S

SA

SBC

SDG

SF

SID

SIDs

SIDS

SPOT4

SSS

$\mathrm{T}$

TAUA

TC

TCO

TDCO

TOT_TOUR
Rainfall in country of Origin

Season

Seasonally-adjusted series

Schwarz Bayesian

Sustainable Development Goals

Seasonal factor

Small Island Destination

Small Island Destinations

Small Island Developing States

Satellite Pour l'Observation de la Terre 4

Sun Sand Sea

Trend

Temperature in Aruba

Trend-cycle

Temperature in Country of Origin

Tourism Demand to Aruba From Country of Origin

Total Tourism Demand 
TOUR

TBL

VAR

VBD

VEC

VENRAIN

VENTEMP

VENTOUR

VENWIN

VIP

VIS

WAUA

WCO

WHO

WMO

WTTC

UECM
Total Number of Stay-Over Visitors

Triple Bottom Line

Vector Autoregressive

Vector-Borne Diseases

Vector Error Correction

Venezuela Rainfall Data

Venezuela Temperature Data

Venezuela Tourism Demand

Venezuela Windspeed Data

Vegetation Index and Phenology

Visible Light

Wind in Aruba

Wind in Country of Origin

World Health Organization

World Meteorological Organisation

World Travel \& Tourism Council

Unrestricted Error Correction Model 


$\begin{array}{ll}\text { UK } & \text { United Kingdom } \\ \text { UNCED } & \text { United Nations Conference on Environment and } \\ \text { UNEP } & \text { Development } \\ \text { UNESCO } & \text { United Nations Environment Program } \\ \text { UNFCCC } & \text { United Nations Educational, Scientific and Cultural } \\ & \text { Organization } \\ \text { UNWTO } & \text { United Nations Framework Convention on Climate } \\ \text { USA } & \text { United Nations World Tourism Organization } \\ \text { US } & \text { United States of America } \\ \text { USARAIN } & \text { United States } \\ \text { USATEMP } & \text { United States of America Rainfall Data } \\ \text { USATOUR } & \text { United States of America Temperature Data } \\ \text { USAWIND } & \text { United States of America Tourism Demand from } \\ & \text { North East Area } \\ & \text { United States of America Windspeed Data }\end{array}$




\section{English Summary}

This study set out to investigate the relationship between different natural factors and tourism demand for a Small Island Destination. Specifically, it examined how climate, infectious diseases, and vegetation affect tourism and vice-versa. It also questioned whether tourism could influence infectious diseases or vegetation in the context of a Small Island Destination. Tourism is one of the biggest industries in the world and also one of the fastest-growing economic segments. According to the United Nations World Tourism Organisation, the number of tourists worldwide has risen from 25 million in 1950 to 1,401 million (or 1.4 billion) in 2018 , while the international tourism revenue of destinations worldwide has been increased from US\$ 2 billion in 1950 to US\$ 1,451 billion (or 1.5 trillion) in 2018.

Furthermore, in 2019 the World Travel \& Tourism Council indicated that for the Caribbean, the tourism sector accounted for $15.5 \%$ of the GDP, and for a Small Island Destination as Aruba, the tourism sector accounted for 98.3\% of the GDP. The number of international tourists worldwide is expected to increase by $3.3 \%$ annually to 1.8 billion by 2030 . An increasing number of destinations now consider tourism to be an essential driver of socio-economic development through job and business creation, export earnings, and infrastructure development. A key aspect of tourism development is tourism demand, which is defined as a measure of the use of goods and services by visitors. It is the basis on which all decisions in the field of tourism are based, as it determines the profitability of airlines, tour operators, hotels, cruise ships, leisure facilities, retailers, and the like. Considering the importance of tourism for the economy and its development potential, the most critical questions for decision-makers are: Which elements trigger tourism demand in a region? 
In the current study, three main aspects that could influence tourism or be influenced by tourism were further investigated. The investigation consisted of three parts. In the first part, the possible relationships between time variations in the climate and the demand for tourism were explored. Climate is of particular importance for the tourism industry, as it can lead to fluctuations in tourist demand for destinations. Climate can be more decisive for tourism demand than some common economic factors, such as income, relative prices, and trade.

The second part investigated a possible link between an infectious disease (dengue) and its impact on the local population and tourism due to the seasonality of tourism demand in a Small Island Destination. Travel is part of human DNA, but this activity is not risk-free as it can, for example, be vulnerable to terrorism, wars, natural disasters, energy crises, economic recessions, and infectious diseases. The coronavirus disease 2019 (COVID-19), for example, has dealt an unprecedented blow to the tourism sector and reduced international tourist arrivals in 2020 to a fraction of what they were in 2019. Since humans began migrating, travel has been a driving force in the onset of infectious diseases, and this is still the case in today's travel era. Tourists are at risk of becoming infected with many kinds of infectious diseases, but there are some cases where it has been established that travelers have transmitted contagious diseases to the local population.

The third part of the research was devoted to the study of changes in land use, i.e., the gradient change of vegetation as a result of economic and tourism development. The research community widely recognizes that both tourism and the environment are interlinked. Tourist destinations are unique, depending on the natural characteristics of the places, which only become available to tourists when they are transformed (or integrated) into products and services (i.e., a commercialization) process. This commercialization process can harm the environment (e.g., environmental pollution, ecological 
damage) if not adequately planned, and can ultimately result in a destination becoming less attractive to a tourist for many reasons.

Although these studies only take into account some determining factors, i.e., climate, infectious disease, land-use change, the idea behind this study is a dynamic approach to understanding the demand for tourism. Therefore one is continually looking for new determining factors of tourism demand instead of operating around some common selective factors affecting tourists' decisions to visit a destination.

Since tourism is a complex phenomenon, no single theory is capable of explaining it. The theoretical framework behind this study was a compendium of three approaches, namely, Chaos Theory, Sustainable Development, and Systems Theory. Chaos Theory was used due to the non-linearity nature of some of the variables. Sustainable development theory was utilized because of the long-term stability in some of the variables. While the Systems Theory was applied due to the interactions between many variables owing to the openness and complexity in some of the variables. With all the above in mind, a pluralistic strategy considering several theoretical frameworks would provide a better understanding of tourism developments than would be the case with a mono-theoretical approach.

The island of Aruba was used as a case study. Aruba is highly regarded in terms of specialization in tourism, contribution to employment, and human development. Results gained from individual case studies do not need to have isolated validity. Case studies, even if done in one country, can be useful for the broader tourism literature, as they can promote new ideas and theoretical formulations. 
This study investigated the following central question:

What is the connection between tourism demand in a Small Island Destination and natural factors (SID)?

This question aims to provide insight into a possible bilateral relationship between the demand for tourism and natural factors, from the perspective of a Small Island Destination. Four detailed sub-questions were formulated to answer the main question.

1. What is the connection between tourism demand development and vegetation in a Small Island Destination?

2. Do cycles of climate affect tourism demand in a Small Island Destination?

3. Do seasonal factors of climate affect tourism demand in a Small Island Destination?

4. What is the connection between seasonal factors of tourism demand development and dengue in a Small Island Destination?

This study contributes to the tourism literature in various ways. Firstly, the study provides new ideas on analyzing the relationship between natural factors and seasonal and cyclical developments in tourism demand. Secondly, this study simultaneously examined the effect of both pull and push climate factors on the cyclical and seasonal demand movements for tourism on a small island, which, as far as assessed, is not common in time series-based studies of this relationship. Thirdly, previous studies on dengue fever, while suggestive, have often been insufficient to determine how dengue affects seasonal patterns of tourism demand in Small Island Destinations. In the study on dengue, it was further shown that tourism demand is more than a passive factor and can be a double-sided sword, acting on one side favorable for the economy and, on the other side, also unfavorable. Fourthly, as far as can be assessed, only a few studies using the normalized difference vegetation index (NDVI) have been conducted to track the gradient in vegetation due to tourism growth on a Small Island Destination. Finally, this study contributes to the process of theory 
formation by providing different theoretical propositions according to the case study approach applied in individual studies.

Chapter 1 gives the purpose and scope of the study, then provides background information on economic and non-economic factors that influence tourism, such as climate, infectious diseases, and the environment. Afterward, the theoretical framework, research questions, hypotheses tested in this study, methodological foundations, research significance, and outline of the study were given.

The study contains three main sections. Part I discussed the possible links between temporal climate fluctuations and tourism demand in more detail. In Chapter 2 ('Impacts of seasonal patterns of climate on recurrent fluctuations in tourism demand Evidence from Aruba'), this study estimated the effect of seasonal patterns of pull and push climate elements (rainfall, temperature, wind and cloud cover) on recurring fluctuations in tourist demand from the United States and Venezuela to Aruba. The seasonal patterns were first isolated from the series using a specialized decomposition method, after which the analysis included panel data unit root testing, panel data regression, and Euclidean distance calculation. The final results showed that both pull and push seasonal factors of climate were relevant in determining the seasonal variations in the tourism demand of both countries. In the case of the United States, the seasonal factors of cloud cover and wind speed in Aruba were important pull factors, while rainfall, temperature, and wind speed in the United States were essential push factors. In the case of Venezuela, the two crucial climatic pull factors were rainfall and temperature on Aruba, while rainfall in Venezuela was a significant push factor. Also, short-term movements in United States tourist demand were influenced by holidays and vacations, while the timeshare factor could be a third element in the seasonal behavior of tourists in the US. In the case of Venezuela, the findings did not point to a significant role for vacations and holidays, possibly due to the lock-in 
effect. In chapter 3 ('Impacts of cyclic patterns of climate on fluctuations in tourism demand Evidence from Aruba'), the study estimated the influence of cyclical climate patterns of pull and push climate elements (rainfall, temperature, wind), including the ENSO and the NAO variables on cyclical fluctuations in tourism demand from the United States, the Netherlands, and Venezuela on a Small Island Destination. Wavelet analysis was used because meteorological and economic time-series are typically noisy, complicated, and strongly non-stationary. Results showed that both pull and push cyclical climate factors had an influence on tourism demand from the United States, the Netherlands, and Venezuela. ENSO and NAO also had an impact on tourism demand from the United States and the Netherlands. The results of chapters 2 and 3 showed that Aruba's climate is a compelling factor for determining shortterm movements in tourism demand. The findings are interesting because they show that merely monitoring economic factors is not enough when it comes to analyzing short-term determinants of tourism demand. The study further confirms that tourism is an open system with connections to other systems. As economic factors are not sufficient to model tourism demand, it also seems complete to take climate into account as an essential determinant of tourism to achieve sustainability in tourism with a view to the long-term continuity of the industry.

Part II explored a possible link between an infectious disease (dengue) and its impact on the local population and tourism as a result of seasonal fluctuations in the flow of tourists to a Small Island Destination. The study in chapter 4 ('The Bilateral Relationship Between Tourism and Dengue Occurrence: Evidence from Aruba') estimated the bilateral effects between seasonal patterns of dengue incidences and the recurring fluctuations of both stay-over tourism and cruise tourism. Seasonal patterns were first isolated from the series using a specialized decomposition method, after which the analysis included panel data unit root testing, panel data regression, and Mahalanobis 
distance calculation. The results showed that cruise tourism increased dengue cases in Aruba, while dengue cases themselves had no influence on the number of stay-over and cruise visitors in Aruba. The study hinted for an economic duality in cruise tourism in Aruba: (1) on the one hand, cruise tourists who arrive at the harbor contribute to the economy of Aruba due to their spending activities; and (2) cruise tourists can induce costs by increasing the risk of spreading dengue. The study also confirmed the open system nature of tourism, where many variables influence each other.

The last section of the study examined land-use change, i.e., the gradient change of vegetation due to economic and tourism development. Specifically, the relationship between land use and conversion due to tourism development and economic growth was investigated. Chapter 5 ('The Connection of Vegetation with Tourism Development and Economic Growth: A Case Study for Aruba') examined the possible impact of tourism development and economic growth on the health of Aruba's vegetation. In the analysis, econometric co-integration and causality tests were used. The calculations showed that there were relationships between tourism demand and economic growth on the health of Aruba's vegetation for the western part of the island (Area 2 NOORD). For the central part of the island (Area 1 ARIKOK), on the other hand, no relationships were found. First, the results again showed the open nature of tourism. The study also showed the importance of remote sensing nowadays in development planning. Overall the study in Chapter 5 improved the overall strategy for achieving sustainable development in a Small Island Destination.

The four studies in Chapters $2-5$ tested seven hypotheses. Hypotheses 1, 2, 3, 4, and 6 were all validated, while 5 and 7 were rejected. Hypothesis 1 through 3 looked at the relationship of seasonal weather patterns, cyclical climate patterns, ENSO, NAO, and tourism demand deviations on Aruba. Hypothesis 4 studied the directional relationship between the number of 
tourists toward the occurrence of dengue, while hypothesis 5 looked at the opposite. The main idea in hypotheses $4-5$, was to find a causal bilateral link between the demand for tourism, dengue. Hypotheses 6 and 7, tested whether there was a causal bilateral link between tourism in Aruba and land use. The following table summarizes the validation results of the selected hypotheses (H1 to $\mathrm{H} 7)$. 
Summary of the hypotheses and their validations.

\begin{tabular}{lll}
\hline Hypothesis & $\begin{array}{c}\text { Based on an empirical } \\
\text { study in } \\
\text { rejection or }\end{array}$ & Chapter 2 \\
\hline $\mathrm{H}_{1}: \quad \begin{array}{l}\text { Seasonal climate elements in Aruba, the United States, and Venezuela, } \\
\text { respectively, are essential in determining the seasonal variations of tourism } \\
\text { demand from the United States and Venezuela. }\end{array}$ & Validated & Chapter 3 \\
$\mathrm{H}_{2}: \begin{array}{l}\text { Cyclic patterns of pull and push climate elements in Aruba, The Netherlands, the } \\
\text { United States, and Venezuela affect the cyclical deviations of tourism demand } \\
\text { for a small destination like Aruba. }\end{array}$ & Validated \\
$\mathrm{H}_{3}: \begin{array}{l}\text { The El Nino Southern Oscillation (ENSO) and the North Atlantic Oscillation } \\
\text { (NAO), affect the cyclical deviations of tourism demand for Aruba. }\end{array}$ & Validated & Chapter 3 \\
$\mathrm{H}_{4}: \quad \begin{array}{l}\text { Seasonal tourism demand has an impact on seasonal dengue occurrences in } \\
\text { Aruba. }\end{array}$ & Validated & Chapter 4 \\
$\mathrm{H}_{5}: \quad \begin{array}{l}\text { Seasonal dengue occurrences have an impact on seasonal tourism demand for } \\
\text { Aruba. } \\
\text { Tourism demand for Aruba has a long-run impact on vegetation density } \\
\text { fluctuations on the island. }\end{array}$ & Rejected & Chapter 4 \\
$\mathrm{H}_{6}: \begin{array}{l}\text { Vegetation density fluctuations in Aruba have a long-run impact on tourism } \\
\text { demand for the island. }\end{array}$ & Rejected & Chapter 5 \\
$\mathrm{H}_{7}$ & Chapter 5
\end{tabular}


The main focus of this study was the connection between tourism demand in a Small Island Destination and natural factors. The essential conclusions and findings are summarized as follows. Firstly, the climate is a crucial natural factor affecting tourism demand as its effect is time- and motivation-variant (pull and push). These dimensions can provide a range of combinations under which the climate can influence the tourist demand for destinations. Second, the relationship between dengue occurrence and tourism demand could be bilateral and dependent on the type of tourist (stay-over or cruise tourism) that a destination caters to. The latter has an impact on the level of risk of infectious diseases experienced by a tourist destination and on the cause-effect relationship with the tourism sector. Third, tourism demand and vegetation (i.e., land-use change) could have a symbiotic relationship, as the development of one can have implications for the other, and vice versa.

In general, the study provided new ideas for analyzing the relationship between natural factors and the development of tourism demand in the short and long term. Specifically, it was shown that with the use of remote sensors, one could gauge how economic and tourism booms on Aruba had a direct impact on the short- and long-term of the gradient of the vegetation on Aruba. Furthermore, it was shown that when looking at weather and climate variables, one has to look at both short-term when it comes to seasonality, but also on the long-run since patterns such as ENSO and NAO can affect the continuity of tourism demand in the long-term. The study also contributed to the process of theory building by providing some theoretical implications stemming from the case-study approach applied in the investigation.

Future studies may extend the depth and scope of the studied determinants of the dynamics of tourism demand and the resulting theoretical implications. For example, more destinations should be included, and the study period should be extended when more data becomes available. Future studies should look at other types of infectious diseases and how they affect different 
forms of tourism (e.g., residential tourism versus cruise tourism), and whether the latter can also contribute to the further spread of these diseases. Concerning the research on vegetation cover and tourism demand, a database based on aerial photographs and measurements of plant species in the target area could provide additional useful information for study purposes. Although not studied in this thesis, investigating the value that an islander would attach to each of the individual dimensions of quality of life, e.g., the environmental aspect versus an economic or political perspective, would contribute to the promotion of literature and could be important for Small Island Destinations.

This dissertation studied the effects of various natural factors that can influence the path of tourism demand on a Small Island Destination. It was shown that the dynamics of tourism demand could be affected by a wide range of factors related to time dimensions and reciprocal effects. This influence has the necessary implications for our understanding of the drivers of tourism demand. At the same time, the study presented new avenues for future research and theorization of tourism demand. Finally, the study showed that even a case study of a Small Island Destination could provide material for expanding the tourism literature. 



\section{Nederlandse Samenvatting}

Deze studie heeft tot doel de relatie tussen verschillende natuurlijke factoren en de toeristische vraag naar een kleine eilandbestemming te onderzoeken. In het bijzonder werd onderzocht hoe het klimaat, besmettelijke ziekten en de vegetatie het toerisme beïnvloeden en vice versa. Ook werd de vraag gesteld of het toerisme invloed zou kunnen hebben op infectieziekten of de vegetatie in de context van een kleine eilandbestemming.

Het toerisme is een van de grootste industrieën ter wereld en ook een van de snelst groeiende economische segmenten. Volgens de Wereldorganisatie voor Toerisme van de Verenigde Naties is het aantal toeristen wereldwijd gestegen van 25 miljoen in 1950 tot 1,401 miljoen (of 1,4 miljard) in 2018, terwijl de internationale toeristische inkomsten van bestemmingen wereldwijd zijn gestegen van 2 miljard dollar in 1950 tot 1,451 miljard dollar (of 1,5 biljoen) in 2018.

Een soortgelijk beeld is te zien in het Caribisch gebied. De World Travel \& Tourism Council geeft in 2019 aan dat in het Caribisch gebied de toeristische sector goed was voor 15,5\% van het Bruto Binnenlands Product. Voor een kleine eiland bestemming als Aruba was de toeristische sector goed voor 98.3\% van het Bruto Binnenlands Product. Naar verwachting zal het aantal internationale toeristen wereldwijd met 3,3\% per jaar toenemen tot 1,8 miljard in 2030. Een toenemend aantal bestemmingen beschouwt het toerisme nu als een onmisbare motor voor de sociaal-economische ontwikkeling door het creëren van banen en bedrijven, exportinkomsten en de ontwikkeling van de infrastructuur. Een belangrijk aspect van de ontwikkeling van het toerisme is de toeristische vraag, die wordt gedefinieerd als een maatstaf voor het gebruik van goederen en diensten door bezoekers. Het is de basis waarop alle beslissingen op het gebied van toerisme wordt genomen, aangezien het de winstgevendheid van luchtvaartmaatschappijen, tour-operators, hotels, cruiseschepen, vrijetijdsvoorzieningen, detailhandelaren en dergelijke bepaalt. 
Gezien het belang van het toerisme voor de economie en het ontwikkelingspotentieel ervan, is de belangrijkste vraag voor de besluitvormers wat de elementen zijn die de vraag naar toerisme in een regio op gang brengen.

In het onderzoek zijn drie belangrijke aspecten die van invloed kunnen zijn of beïnvloed kunnen worden door het toerisme verder onderzocht. In het eerste deel van de studie werden de mogelijke verbanden tussen tijdvariaties in het klimaat en de toeristische vraag onderzocht. Het klimaat is van bijzonder belang voor de toeristische industrie, omdat het kan leiden tot schommelingen in de toeristische vraag naar bestemmingen. Het klimaat kan meer bepalend zijn voor de toeristische vraag dan sommige gemeenschappelijke economische factoren, zoals inkomen, relatieve prijzen en handel.

In het tweede deel werd een mogelijk verband onderzocht tussen een besmettelijke ziekte (dengue) en haar invloed op de lokale bevolking en het toerisme als gevolg van het seizoengebonden karakter van de toeristische vraag in een kleine eiland bestemming. Reizen maakt deel uit van de DNA van de mens, maar het gaat om een activiteit die niet zonder risico's is, aangezien ze kwetsbaar kan zijn voor bijvoorbeeld terrorisme, oorlogen, natuurrampen, energiecrises, economische recessies en besmettelijke ziekten. Zo heeft de coronavirusziekte 2019 (COVID-19) de toeristische sector een ongekende klap toegebracht en de internationale toeristenaantallen in 2020 teruggebracht tot een fractie van wat ze in 2019 waren. Sinds mensen zijn gaan migreren, is reizen een drijvende kracht geweest achter het ontstaan van besmettelijke ziekten, en dat is meer dan ooit het geval in het huidige reistijdperk. Toeristen lopen het risico besmet te raken met vele soorten infectieziekten, maar er zijn ook gevallen bekend waarin reizigers besmettelijke ziekten hebben overgedragen op de lokale bevolking.

Het derde deel van de studie was gewijd aan de studie van veranderingen in het landgebruik, dus de gradiëntverandering van de vegetatie als gevolg van de economische en toeristische ontwikkeling. De 
onderzoekgemeenschap is zich ervan bewust dat zowel het toerisme als het milieu met elkaar verbonden zijn. Toeristische bestemmingen zijn uniek, afhankelijk van de natuurlijke kenmerken van de plaatsen, die pas beschikbaar komen voor toeristen wanneer ze worden omgezet (of opgenomen) in producten en diensten (d.w.z. een commercialiseringsproces). Dit commercialiseringsproces kan het milieu schaden (bijvoorbeeld milieuvervuiling, ecologische schade) als het niet goed is voorbereid, en kan een bestemming uiteindelijk om vele redenen minder aantrekkelijk maken voor een toerist.

Hoewel deze studies zich beperken tot een aantal bepalende factoren, zoals het klimaat, besmettelijke ziekten en veranderingen in het landgebruik, bieden zij een dynamische benadering om de vraag naar toerisme te begrijpen. Dat is de reden dat men voortdurend op zoek is naar nieuwe beslissende factoren voor de vraag naar toerisme in plaats van zich te beperken tot de gebruikelijke specifieke factoren die van invloed zijn op de beslissingen van toeristen om een bestemming te bezoeken.

Aangezien toerisme een complex fenomeen is, kan geen enkele individuele theorie het hele veld overzien. Een multidisciplinaire anpak die verschillende theoretische kaders in overweging neemt, kan gezien de complexiteit van het veld een beter begrip opleveren van de ontwikkelingen in het toerisme dan een monotheoretische aanpak. Het theoretische kader achter deze studie was daarom een combinatie van drie benaderingen, namelijk chaostheorie, duurzame ontwikkeling en systeemtheorie. Chaostheorie werd gebruikt vanwege de non-lineariteit van sommige van de variabelen. De theorie van duurzame ontwikkeling werd gebruikt vanwege de stabiliteit op lange termijn in sommige van de variabelen, terwijl de systeemtheorie werd toegepast vanwege de interacties tussen vele variabelen vanwege de openheid en complexiteit in sommige variabelen. 
Aruba, die als casestudy werd gebruikt, staat hoog op de ranglijst wat betreft specialisatie in toerisme, bijdrage aan werkgelegenheid en menselijke ontwikkeling. Een casestudy die in staat is een gedifferentieerd inzicht te geven in een vraagstuk kan een verrijking betekenen voor de algemene literatuur op een gebied die verder reikt dan het individueel geval dat onderzocht is. Een case study van een bepaald land kan daarom nuttig zijn voor de algemene toeristische literatuur, omdat ze nieuwe ideeën en theoretische formuleringen kunnen bevorderen, vooral wanneer andere landen soortgelijke condities hebben.

In deze studie werd de volgende centrale vraag onderzocht:

Wat is het verband tussen de toeristische vraag in een kleine eiland bestemming (Small Island Destination, afgekort SID) en natuurlijke factoren?

Deze vraag heeft tot doel inzicht te geven in een mogelijke tweezijdige relatie tussen de toeristische vraag en natuurlijke factoren, vanuit het perspectief van een kleine eiland bestemming. Om de centrale vraag te beantwoorden zijn vier specifieke deelvragen geformuleerd:

1. Wat is de relatie tussen de ontwikkeling van de toeristische vraag en de vegetatie in een kleine eiland bestemming?

2. Hebben klimaatcycli invloed op de vraag naar toerisme in een kleine eiland bestemming?

3. Hebben seizoensgebonden klimaatfactoren invloed op de vraag naar toerisme in een kleine eiland bestemming?

4. Wat is het verband tussen de seizoensgebonden factoren van de toeristische vraag en de dengue in een kleine eiland bestemming?

Deze studie levert op verschillende manieren een bijdrage aan de literatuur over het toerisme. Ten eerste levert de studie nieuwe ideeën over het analyseren van de relatie tussen natuurlijke factoren en seizoensgebonden en cyclische ontwikkelingen in de toeristische vraag. Ten tweede wordt in deze studie tegelijkertijd gekeken naar het effect van zowel pull- als push- 
klimaatfactoren op de cyclische en seizoensgebonden vraagontwikkeling van het toerisme op een klein eiland bestemming, wat, voor zover beoordeeld, niet gebruikelijk is in op tijdreeksen gebaseerde studies van deze relatie. Ten derde zijn eerdere studies naar dengue weliswaar suggestief, maar vaak onvoldoende om te bepalen hoe dengue de seizoensgebonden patronen van de toeristische vraag op kleine eiland bestemmingen beïnvloedt. De studie over dengue heeft verder aangetoond dat de vraag naar toerisme meer is dan een passieve factor en een tweezijdig zwaard kan zijn dat enerzijds gunstig is voor de economie en anderzijds ongunstig. Ten vierde zijn er, voor zover te beoordelen, slechts enkele studies uitgevoerd met de NDVI (Normalized Difference Vegetation Index) om de gradiënt in de vegetatie als gevolg van de groei van het toerisme op een klein eiland bestemming te monitoren. Tot slot draagt deze studie bij aan het proces van theorievorming door verschillende theoretische stellingen te leveren volgens de casestudy-benadering die in individuele studies wordt toegepast.

Hoofdstuk 1 geeft het doel en de reikwijdte van de studie aan en geeft vervolgens basisinformatie over economische en niet-economische factoren die van invloed zijn op het toerisme, zoals het klimaat, besmettelijke ziekten en het milieu. Vervolgens worden het theoretische kader, onderzoekvragen, getoetste hypothesen, methodologische onderbouwing, onderzoekwaarde en opzet van de studie gegeven.

De studie bestaat uit drie hoofdonderdelen. In deel I worden de mogelijke verbanden tussen tijdelijke klimaatschommelingen en de vraag naar toerisme nader besproken. Aan de hand van hoofdstuk 2 ('Impacts of seasonal patterns of climate on recurring fluctuations in tourism demand Evidence from Aruba') wordt een schatting gemaakt van het effect van seizoengebonden pull en push klimaatelementen (regenval, temperatuur, wind en bewolking) op terugkerende bewegingen in de toeristische vraag vanuit de Verenigde Staten en Venezuela naar Aruba. De seizoensgebonden patronen werden eerst 
geïsoleerd uit de reeks door een gespecialiseerde methode voor reeksendecompositie, waarna de analyse onder meer bestond uit panel data unit root testing, panel data regressie, en Euclidische afstandsberekening. De uiteindelijke resultaten toonden aan dat zowel pull- als push-seizoengebonden klimaatfactoren belangrijk waren bij het bepalen van de seizoensgebonden variaties in de toeristische vraag van beide landen. In het geval van de Verenigde Staten waren de seizoensgebonden factoren van bewolking en windsnelheid op Aruba belangrijke pull factoren, terwijl regenval, temperatuur en windsnelheid in de Verenigde Staten essentiële push factoren waren. In het geval van Venezuela waren de twee belangrijkste klimatologische aantrekkingsfactoren regenval en temperatuur op Aruba, terwijl regenval in Venezuela een belangrijke push-factor was. Daarnaast werden de kortetermijnbewegingen in de toeristische vraag van de Verenigde Staten beïnvloed door feestdagen en vakanties, terwijl de timeshare-factor een derde element kon zijn in het seizoengebonden gedrag van toeristen in de Verenigde Staten. In het geval van Venezuela wezen de bevindingen niet op een statistisch geldige rol voor feestdagen en vakanties, mogelijk als gevolg van het lock-ineffect. In hoofdstuk 3 ('Impacts of cyclic patterns of climate on fluctuations in tourism demand Evidence from Aruba') schatte de studie de invloed in van cyclische klimaatpatronen van pull en push klimaatelementen (regenval, temperatuur, wind), waaronder de ENSO en de NAO-variabelen op de cyclische schommelingen in de toeristische vraag vanuit de Verenigde Staten, Nederland en Venezuela naar een kleine eiland bestemming. Er is gebruik gemaakt van Wavelet-analyse omdat meteorologische en economische tijdreeksen typisch ruisend, ingewikkeld en grotendeels niet-stationair zijn. De resultaten toonden aan dat zowel pull als push cyclische klimaatfactoren van invloed waren op de toeristische vraag vanuit de Verenigde Staten, Nederland en Venezuela. ENSO en NAO hadden ook invloed op de vraag naar toerisme uit de Verenigde Staten en Nederland. De resultaten van de hoofdstukken 2 en 
3 lieten zien dat het klimaat op Aruba een belangrijke factor is voor het bepalen van de bewegingen op korte termijn in de toeristische vraag. De bevindingen zijn opmerkelijk, omdat ze aantonen dat het monitoren van economische factoren niet voldoende is als het gaat om het beoordelen van de determinanten van de toeristische vraag op korte-termijn. De studie bevestigt verder dat het toerisme een open systeem is met verbindingen met andere systemen. Aangezien economische factoren de vraag naar toerisme niet afdoende kunnen verklaren, moet ook rekening worden gehouden met andere factoren zoals klimatologische parameters, als onmisbare determinanten van het toerisme om tot een duurzaam toerisme te komen met het oog op de continuïteit van de sector op lange termijn.

In deel II werd een mogelijk verband onderzocht tussen een besmettelijke ziekte (dengue) en haar invloed op de lokale bevolking en het toerisme als gevolg van seizoensgebonden schommelingen in de stroom van toeristen naar een kleine eiland bestemmingen. De studie in hoofdstuk 4 ('The Bilateral Relationship Between Tourism and Dengue Occurrence: Evidence from Aruba') schatte de tweezijdige effecten in tussen seizoenpatronen van dengue-incidenten en de herhaaldelijke schommelingen van zowel het verblijftoerisme als het cruisetoerisme. Seizoenpatronen werden eerst geïsoleerd uit de serie met behulp van een speciale reeksen decompositiemethode, waarna de analyse onder meer bestond uit panel data unit root testing, panel data regressie en Mahalanobis afstandsberekening. De resultaten toonden aan dat het cruisetoerisme het aantal denguegevallen op Aruba deed toenemen, terwijl de denguegevallen zelf geen invloed hadden op het aantal verblijf- en cruisetoeristen op Aruba. Het onderzoek wees op een economische dualiteit in het cruisetoerisme op Aruba: (1) aan de ene kant dragen cruisetoeristen die in de haven aankomen bij aan de economie van Aruba door hun bestedingen; en (2) aan de andere kant kunnen cruisetoeristen kosten veroorzaken door het risico op verspreiding van dengue te vergroten. 
Het onderzoek bevestigde ook het open systemische karakter van het toerisme, waarbij veel variabele invloeden elkaar beïnvloeden.

In het laatste deel van de studie werd de verandering in landgebruik onderzocht, d.w.z. de verandering in de gradiënt van de vegetatie als gevolg van de economische en toeristische ontwikkeling. Specifiek werd de relatie tussen landgebruik en verandering als gevolg van de ontwikkeling van het toerisme en de economische groei onderzocht. Hoofdstuk 5 ('The Connection of Vegetation with Tourism Development and Economic Growth: A Case Study for Aruba') onderzocht de mogelijke impact van de ontwikkeling van het toerisme en economische groei op de gezondheid van de vegetatie op Aruba. Bij de analyse is gebruik gemaakt van econometrische co-integratie- en causaliteitstoetsen. De berekeningen toonden aan dat er relaties waren tussen de toeristische vraag en de economische groei op de gezondheid van de vegetatie van Aruba voor het westelijk deel van het eiland (Area 2 NOORD). Voor het centrale deel van het eiland (Area 1 ARIKOK) werden daarentegen geen relaties gevonden. Ten eerste toonden de resultaten opnieuw het open systemische karakter van het toerisme aan. Het onderzoek toonde ook aan hoe belangrijk remote sensing tegenwoordig is in de ontwikkelingsplanning. Het onderzoek in hoofdstuk 5 leidt tot een verbetering van de algemene plan voor het bereiken van duurzame ontwikkeling in een kleine eilandstaat.

De vier studies in hoofdstuk 2 - 5 zijn getoetst aan zeven hypothesen. Hypotheses 1, 2, 3, 4 en 6 werden allemaal bevestigd, terwijl 5 en 7 werden verworpen. In de hypothesen 1 tot en met 3 is gekeken naar de relatie tussen seizoensgebonden weerpatronen, cyclische klimaatpatronen, ENSO, NAO en afwijkingen in de toeristische vraag op Aruba. Hypothese 4 onderzocht de richtingsgebonden relatie tussen het aantal toeristen gericht op het optreden van dengue, terwijl hypothese 5 naar het tegenovergestelde keek. Het hoofdidee in hypothese 4-5 was het vinden van een tweerichtingsrelatie tussen de vraag naar toerisme, en dengue. In hypothese 6 en 7 werd onderzocht of er een tweezijdig 
verband was tussen toerisme op Aruba en landgebruik. De tabel op de volgende pagina geeft een samenvatting van de validatieresultaten van de geselecteerde hypothesen ( $\mathrm{H} 1$ tot $\mathrm{H} 7)$.

Het belangrijkste doel van deze studie was het vinden van een verband tussen de vraag naar toerisme in een klein eiland bestemming en natuurlijke factoren. De belangrijkste conclusies en bevindingen kunnen als volgt worden samengevat. Ten eerste is het klimaat een belangrijke natuurlijke factor die van invloed is op de vraag naar toerisme, dit vanwege het effect op de tijd en de motivatie (pull en push). Deze aspecten kunnen zorgen voor een serie van combinaties waarbij het klimaat de toeristische vraag naar bestemmingen kan beïnvloeden. Ten tweede kan de relatie tussen het optreden van dengue en de toeristische vraag tweezijdig zijn en afhankelijk van het type toerist (verblijf of cruisetoerisme) waarop een bestemming zich richt. Dit laatste is van invloed op het risico op besmettelijke ziekten dat een toeristische bestemming loopt en op de oorzaak-gevolgrelatie met de toeristische sector. Ten derde kan de vraag naar toerisme en de vegetatie (verandering van landgebruik) een symbiotische relatie hebben, aangezien de ontwikkeling van de een gevolgen kan hebben voor de ander, en vice versa. 
Samenvatting van de hypothesen en hun validaties.

\begin{tabular}{ll}
\hline Hypothese & $\begin{array}{l}\text { Validatie of } \\
\text { afwijzing }\end{array}$ \\
\hline
\end{tabular}

$\mathrm{H}_{1}$ : Seizoengebonden klimatologische variabelen in respectievelijk Aruba, de Verenigde Staten en Venezuela zijn essentieel voor het bepalen van de seizoengebonden schommelingen in de vraag naar toerisme vanuit de Verenigde Staten en Venezuela.

$\mathrm{H}_{2}$ : De cyclische bewegingen van de pull- en push-klimaatelementen in Aruba, Nederland, de Verenigde Staten en Venezuela zijn van invloed op de cyclische variaties in de toeristische vraag voor een kleine bestemming als Aruba.

$\mathrm{H}_{3}$ : De El Nino Southern Oscillation (ENSO) en de North Atlantic Oscillation (NAO) zijn van invloed op de cyclische variaties in de toeristische vraag op Aruba.

$\mathrm{H}_{4}$ : Seizoengebonden toeristische vraag heeft een impact op de aanwezigheid van seizoengebonden knokkelkoorts op Aruba.

$\mathrm{H}_{5}$ : Seizoengebonden knokkelkoortsverschijnselen hebben een invloed op de Verworpen seizoengebonden behoefte aan toerisme op Aruba.

$\mathrm{H}_{6}$ : De toeristische vraag naar Aruba heeft een langdurige invloed op de schommelingen in de vegetatiedichtheid op het eiland.

$\mathrm{H}_{7} \quad$ Schommelingen in de vegetatiedichtheid op Aruba hebben een langdurige invloed Verworpen op de vraag naar toerisme op het eiland.

Bevestigd Hoofdstuk 2

Bevestigd Hoofdstuk 3

Bevestigd Hoofdstuk 3

Bevestigd Hoofdstuk 4

Hoofdstuk 4

Hoofdstuk 5

Hoofdstuk 5 
Over het algemeen leverde deze studie nieuwe ideeën op voor het bestuderen van de relatie tussen natuurlijke factoren en de ontwikkeling van de toeristische vraag op korte en lange termijn. In het bijzonder werd aangetoond dat met remote sensors gemeten kon worden hoe de economische en toeristische bloei op Aruba een directe invloed heeft op de korte en lange termijn van de gradiënt van de vegetatie op Aruba. Verder werd bewezen dat wanneer men rekening houdt met weer- en klimaatvariabelen, men zowel naar de korte termijn als naar de seizoensgebondenheid moet kijken, maar ook naar de lange termijn, aangezien patronen zoals ENSO en NAO de continuïteit van de toeristische vraag op de lange termijn kunnen beïnvloeden. De studie heeft ook bijgedragen aan het proces van theorievorming door enkele theoretische consequenties te geven die voortvloeien uit de casestudy-aanpak die in de studie wordt toegepast.

In de toekomst kan de studie de diepte en de reikwijdte van de bestudeerde factoren die de dynamiek van de toeristische vraag bepalen, en de bijbehorende theoretische gevolgen, uitbreiden. Zo zouden bijvoorbeeld meer bestemmingen moeten worden opgenomen en zou de studieperiode moeten worden verlengd naarmate er meer gegevens beschikbaar komen. In toekomstige studies moet worden gekeken naar andere soorten infectieziekten en hoe deze verschillende vormen van toerisme beïnvloeden (bijvoorbeeld residentieel toerisme versus cruisetoerisme), en of dit laatste ook kan bijdragen aan de verdere verspreiding van deze ziekten. Wat het onderzoek naar het vegetatiedek en de vraag naar toerisme betreft, zou een databank gemaakt met luchtfoto's en metingen van plantensoorten in het doelgebied nuttige informatie voor studiedoeleinden kunnen opleveren. Hoewel niet onderzocht in dit proefschrift, zou onderzoek naar de waarde die een eilandbewoner zou hechten aan elk van de afzonderlijke dimensies van levenskwaliteit, bijvoorbeeld het milieuaspect versus een economisch of politiek perspectief, bijdragen aan de 
bevordering van de literatuur en van belang kunnen zijn voor kleine eiland bestemmingen.

Dit proefschrift bestudeerde de effecten van verschillende natuurlijke factoren die het verloop van de toeristische vraag op een klein eiland bestemming kunnen beïnvloeden. Er werd aangetoond dat de dynamiek van de toeristische vraag kan worden beïnvloed door een breed scala aan factoren met betrekking tot tijdsdimensies en wederzijdse effecten. Dit heeft de nodige implicaties voor ons begrip van de drivers van de vraag naar toerisme. Tegelijkertijd bood de studie nieuwe mogelijkheden voor toekomstig onderzoek en theorievorming over de vraag naar toerisme. Ten slotte toonde de studie aan dat zelfs een casestudy van een klein eiland bestemming waardevolle informatie kan opleveren voor de uitbreiding van de toeristische literatuur. 


\section{Curriculum Vitae}

Marck Oduber was born on Aruba, Netherlands Antilles, on December $25^{\text {th }}$ 1972. He received his Bachelor of Science degree in Meteorology from the University of Oklahoma,

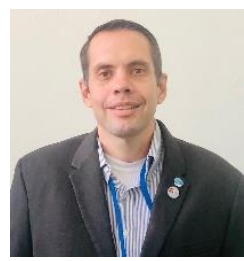
United States of America, in 1998, and a Master of Science degree in Geosciences from the Mississippi State University, also in the United States of America in 2000.

Marck has been working from 2000 through 2010 at the Meteorological Service of the Netherlands Antilles \& Aruba as a research meteorologist. In 2011 the Meteorological Service of Aruba was instituted, and he became the new department director. Marck has followed many additional courses, including courses in meteorology and seismology, and performed duties as a seismologist on Aruba. Furthermore, he has been project leader in many projects on Aruba pertaining to Natural Sciences. Marck is currently also Aruba's UNESCO focal point for IOCARIBE and Tsunami National Contact. He has been elected Vice-Chair of the IOCARIBE in Cartagena, Colombia, in 2017. Since 2018 Marck has also worked with the Minister of Education, Science, and Sustainable Development as a Program Specialist in Sciences for UNESCO Aruba and is working on different science projects on Aruba. The latter includes organizing the Fifteenth Session of the IOC Sub-Commission for the Caribbean and Adjacent Regions (SC-IOCARIBE-XV) on Aruba in May 2019. Marck was also the leader/presenter for the Working Group 3 (A Predicted Ocean) during the Western Tropical Atlantic Regional Workshop, co-organized by the Government of Mexico and IOC/UNESCO. He was also the leader of a UNESCO sponsored workshop on SDG14, organized on Aruba in 2017. In 2012 Marck started with his Ph.D. quest, originally via the Ph.D. program of the University of Aruba, and later as an off-campus doctoral student of the Maastricht University. 



\section{Valorization Addendum}

For some years now, Ph.D. students at the University of Maastricht are expected to write a section on how their research can be translated into social or economic value (valorization). Universities are driving forces in research, but many policymakers do not make optimal use of academic research ${ }^{18}$. Throughout the years, there has been a consistent growth in research into how policy decisions can be based on the results of academic research. This growth has inspired ideas such as "research utilization," "knowledge transfer," "knowledge brokering," and "evidence-based policy ${ }^{19}$ ". Evidence-based policy, for example, is important for making effective and successful policy decisions. The literature on tourism demand has too long focused primarily on economic issues, such as income, price, substitution price, advertising, and supply constraints ${ }^{20}$. This one-sided and narrow approach sets the stage for further dwelling into different factors that influence tourism demand.

In this study, the relationship between several natural factors and tourism demand for a Small Island Destination (SID), Aruba, was investigated. In particular, this study examined the effects of climate, infectious disease, and vegetation on tourism demand and whether tourism demand impacts infectious disease or vegetation. Summarized, the study's main question was to find the connection between tourism demand for Aruba as a Small Island Destination and natural factors, specifically climate, infectious disease, and vegetation.

\footnotetext{
${ }^{18}$ Newman, J., Cherney, A., \& Head, B. W. (2016). Do policy makers use academic research? Reexamining the "two communities" theory of research utilization. Public Administration Review, 76(1), 24-32.

${ }^{19}$ Fisher, J. R., Wood, S. A., Bradford, M. A., \& Kelsey, T. R. (2020). Improving scientific impact: How to practice science that influences environmental policy and management. Conservation Science and Practice, 2(7), e210.

${ }^{20}$ Croes, R. (2010). Anatomy of demand in international tourism: The case of Aruba. Saarbrucken: Lambert Academic Publication.

Goh, C. (2012). Exploring impact of climate on tourism demand. Annals of Tourism Research. Annals of Tourism Research, 3(4), 1859-1883.

Song, H., Witt, S., \& Li, G. (2009). The advanced econometrics of tourism demand. New York: Routledge.
} 
To answer the main question, four sub-questions were formulated:

1. What is the connection between tourism demand development and vegetation in a Small Island Destination?

2. Do cycles (wavelike variations around a trend) of climate affect tourism demand in a Small Island Destination?

3. Do seasonal factors (recurring variations at unique intervals within a year) of climate affect tourism demand in a Small Island Destination?

4. What is the connection between seasonal factors of tourism demand development and dengue in a Small Island Destination?

From a theoretical perspective, it is worth noting that tourism is a complex phenomenon, and no single theory can explain developments in tourism. Therefore, this study included three theories: Sustainable Development, Systems Theory, and Chaos Theory. Sustainable Development was chosen, given its focus on a more long-term vision aspect. The relevance of the Systems theory is due to the openness and complexity of the tourism system, whereas the Chaos Theory was found relevant for explaining the potential outcomes of changes as not solely being based on a simple proportional relationship between cause and effect (non-linearity). By assessing the study through different angles/approaches, many theoretical constructs were taken into account, which will give a better explanation of the development of tourism than a more one-sided, single theoretical approach.

Based on the study questions, the investigation showed that:

- Tourism demand has a connection with vegetation density, where less vegetation on Aruba island did not impact Aruba's tourism demand.

- Seasonal and cyclical variations in climate affect Aruba's tourism demand. These variations include well-known climate variables such as rainfall and temperature, but also climate patterns such as ENSO (El Nino Southern Oscillation) and NAO (North Atlantic Oscillation). 
- Dengue cases are influenced by tourism demand, specifically, cruise tourism. The infectious disease factor is an interesting and actual phenomenon, considering the ongoing COVID-19 pandemic at the time of writing this valorization section (October 2020), and its effect on tourism.

It is important to highlight that the studies conducted in this dissertation are based on a case study approach. Individual case studies can contribute to scientific generalizations (from one or a few facts to a broader/universal statement) through the replication effect (repeating the study with other case studies), where the mode of generalization is analytic (analytic generalization). The goal is to expand and generalize theories and not enumerate frequencies (statistical generalizations). In other words, the findings of the study cannot be generalized to other cases in the world but merely serve as sources for new ideas and theoretical propositions that will benefit future studies. The island of Aruba was used as a case study in the present research due to its consistent success as a highly desirable destination for visitors and has generally experienced one of the Caribbean's highest sustained growth rates.

This dissertation's studies have revealed that stakeholders should take an integrated approach when looking at developments in tourism demand. A combination of methods is needed to predict and manage tourism demand. We need to recognize that tourism development is a non-linear and open system process involving connections between actors, activities, and resources. The latter implies that tourism demand may be affected by many factors beyond the income of the tourists. Having an open mind on these potential determinants is a precondition for policymakers to understand and oversee tourism development in a destination adequately. For example, as the climate seems likely to affect tourism demand, stakeholders should keep an eye on short- and long-term weather forecasts to gain a lead on expected seasonal or cyclical fluctuations and respond to this information by adjusting marketing strategies. 
It is important as well to explain the findings of this study in a language that stakeholders may understand without the technicalities usually involved in these types of studies. Besides face-to-face discussion, producing condensed non-technical articles in specialized magazines could help disseminate the investigation's findings and help others (e.g., policymakers) better understand the workings of tourism.

Besides practical contribution, the study also advanced the body of knowledge by providing several theoretical implications stemming from the investigation. First, climate is a natural factor that affects the demand for tourism, as its impact is time-and motivation-variant (pull and push). These pull and push factors could produce a series of combinations under which climate can impact tourism demand for destinations. Second, the relationship between dengue occurrence and the demand for tourism may be bidirectional, meaning that both can affect each other. The type of tourist matters as well if we distinguish between stay-over and cruise tourism. Third, tourism demand and vegetation may also have a mutual relationship, i.e., the development of one can have consequences for the other, and vice versa.

In addition to providing theoretical propositions, the study also contributed to the tourism literature by first offering new insights into the connection between natural factors and seasonal and cyclical developments in demand for tourism. While the relationship between climate factors and tourism demand was deemed one-sided in this investigation (i.e., climate affecting tourism demand), the study considered the relationships between, on the one hand, infectious diseases and vegetation, and tourism demand, on the other hand, as bilateral or two-sided. The bilateral consideration implies that tourism demand is more than a passive factor and can impact the same factor that influences it. Second, this investigation simultaneously analyzed the effect of both pull and push climate variables on cyclical and seasonal tourism demand movements on the case of study, which is rare when it comes to time- 
series based studies. Third, past studies on dengue, although suggestive, were often inadequate to understand how seasonal patterns of dengue and tourism demand interact with each other in Small Island Destinations. Cruise tourism can act as a double edge sword when it comes to the interaction of dengue and tourism demand (cruise tourists being infected and also infecting residents at the destination). Fourth, as far as could be assessed, only a few numbers of studies were conducted using the normalized difference vegetation index (NDVI) to monitor the gradient in vegetation due to tourism growth on a Small Island Destination. Small Island Destinations rely on tourism for their economic growth, and their natural capital may be a key attraction for tourists.

All things considered, this investigation has shown its practical and academic merits and confirms that even one case study can advance the academic cause and promote applied knowledge to those in the daily operating field of tourism. The study also provides an impetus to future studies to better understand the driving forces of tourism demand. The efforts were not in vain. 